Prepared in cooperation with the Bureau of Land Management

\title{
Assessment of Water Resources and the Potential Effects from Oil and Gas Development in the Bureau of Land Management Tri-County Planning Area, Sierra, Doña Ana, and Otero Counties, New Mexico
}

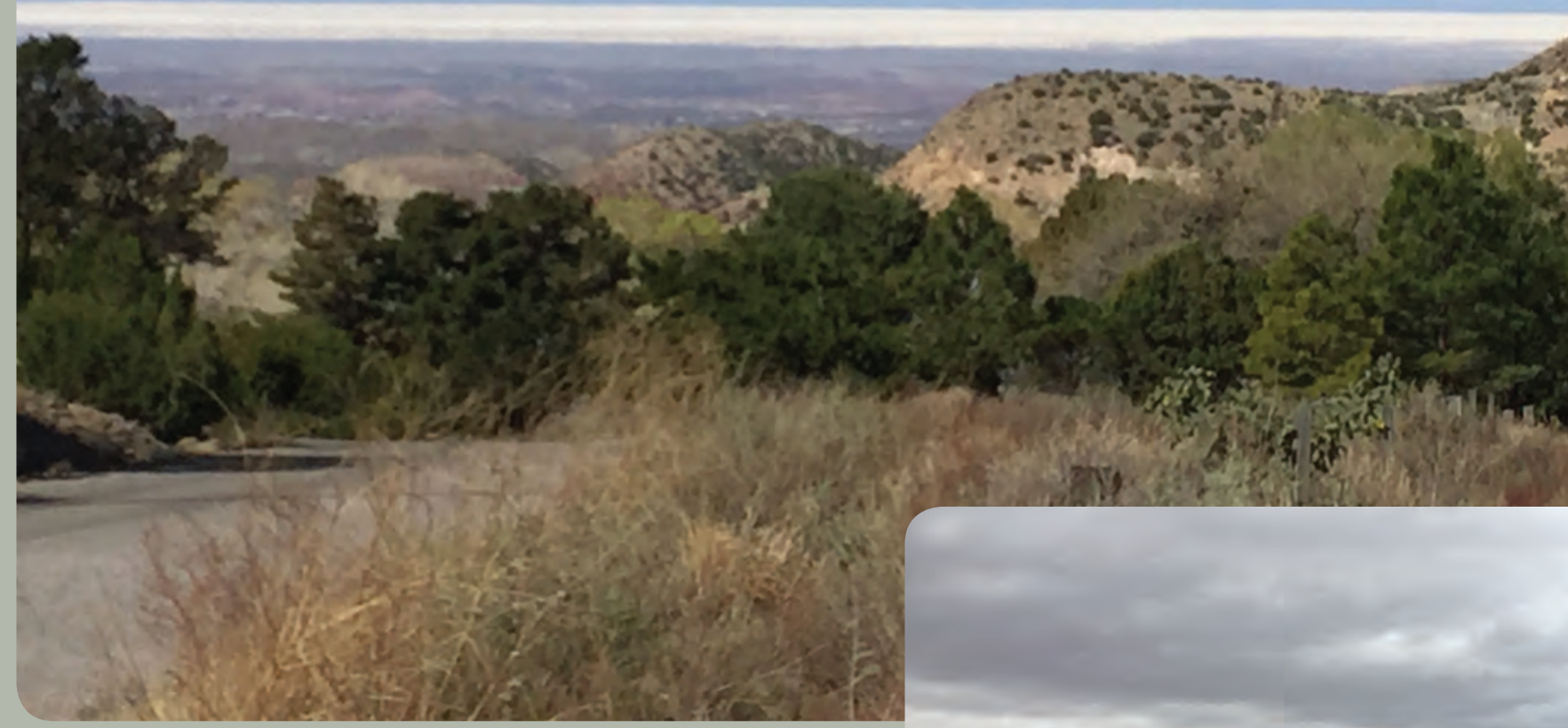

Scientific Investigations Report 2017-5151

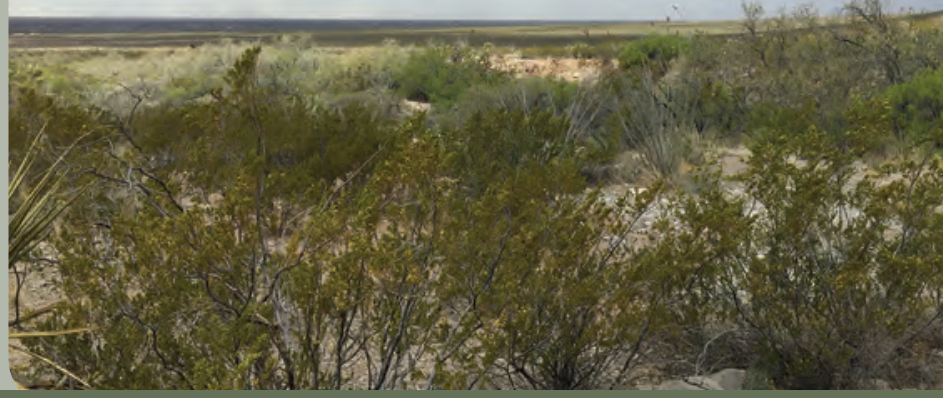




\section{Front cover:}

Top, Photograph showing view from the Sacramento Mountain foothills looking west towards White Sands and the San Andres Mountains.

Bottom, Photograph showing view of the Tularosa Basin from Oliver Lee State Park near Alamogordo, New Mexico.

Back cover, Photograph showing headwaters of the Sacramento River. 


\section{Assessment of Water Resources and the Potential Effects from Oil and Gas Development in the Bureau of Land Management Tri-County Planning Area, Sierra, Doña Ana, and Otero Counties, New Mexico}

By Johanna M. Blake, Keely Miltenberger, Anne Stewart, Andre Ritchie, Jennifer Montoya, Corey Durr, Amy McHugh, and Emmanuel Charles

Prepared in cooperation with the Bureau of Land Management

Scientific Investigations Report 2017-5151 


\title{
U.S. Department of the Interior \\ RYAN K. ZINKE, Secretary
}

\section{U.S. Geological Survey William H. Werkheiser, Deputy Director exercising the authority of the Director}

\author{
U.S. Geological Survey, Reston, Virginia: 2018
}

For more information on the USGS - the Federal source for science about the Earth, its natural and living resources, natural hazards, and the environment-visit https://www.usgs.gov or call 1-888-ASK-USGS.

For an overview of USGS information products, including maps, imagery, and publications, visit https://store.usgs.gov.

Any use of trade, firm, or product names is for descriptive purposes only and does not imply endorsement by the U.S. Government.

Although this information product, for the most part, is in the public domain, it also may contain copyrighted materials as noted in the text. Permission to reproduce copyrighted items must be secured from the copyright owner.

Suggested citation:

Blake, J.M., Miltenberger, Keely, Stewart, Anne, Ritchie, Andre, Montoya, Jennifer, Durr, Corey, McHugh, Amy, and Charles, Emmanuel, 2018, Assessment of water resources and the potential effects from oil and gas development in the Bureau of Land Management Tri-County planning area, Sierra, Doña Ana, and Otero Counties, New Mexico: U.S. Geological Survey Scientific Investigations Report 2017-5151, 87 p., https://doi.org/10.3133/sir20175151.

ISSN 2328-0328 (online) 


\section{Acknowledgments}

This study was conducted in cooperation with the Bureau of Land Management. We would like to thank the following Bureau of Land Management employees for their assistance with this report: Dave Herrell and James Glover and the following U.S. Geological Survey employees for

their assistance with this report: Jessica Hopple, Zach Shephard, Aurelia Mitchell, and Delbert Humberson. 



\section{Contents}

Acknowledgments ............................................................................................................................ii

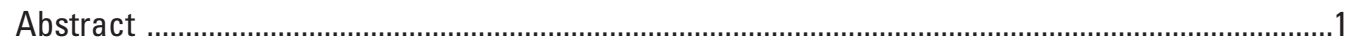

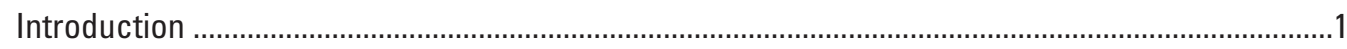

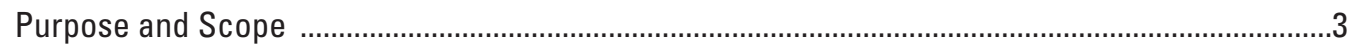

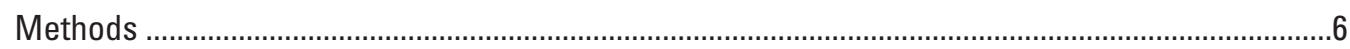

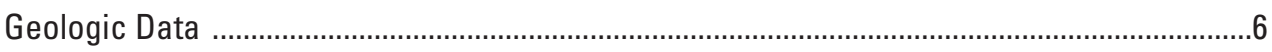

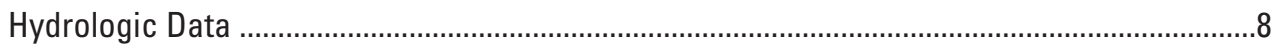

Physical Characteristics of the Tri-County Planning Area ...........................................................

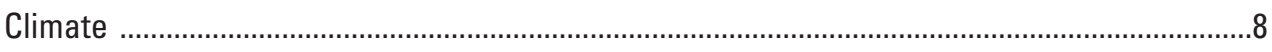

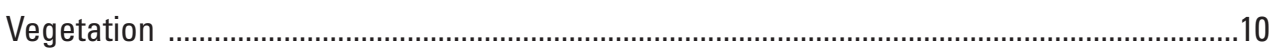

Physiography and Climate Summaries for Identified Basins and Ranges ............................10

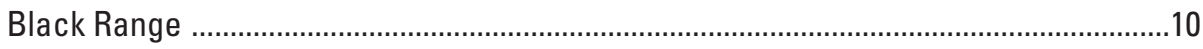

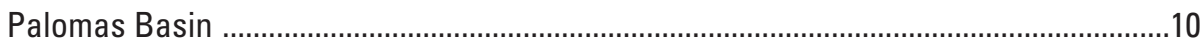

Caballo Mountains and Engle Basin ........................................................................ 10

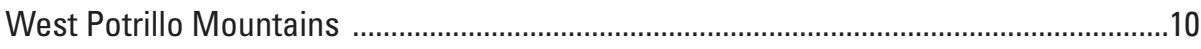

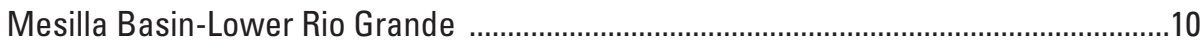

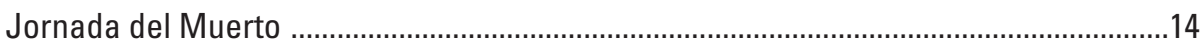

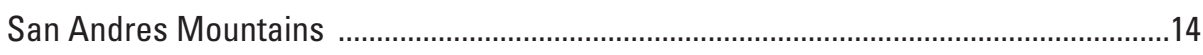

Organ Mountains and Doña Ana Mountains .............................................................14

Hueco Bolson and Tularosa Basin ..............................................................................

Sacramento Mountains ...................................................................................................14

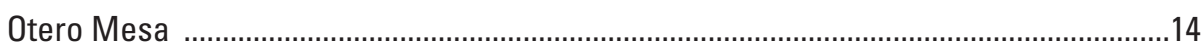

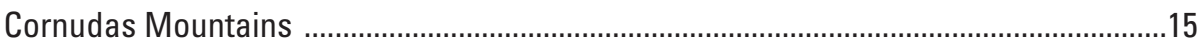

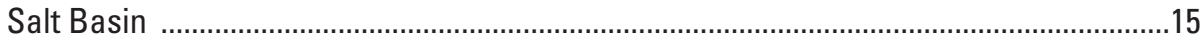

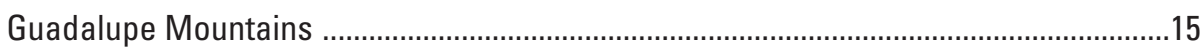

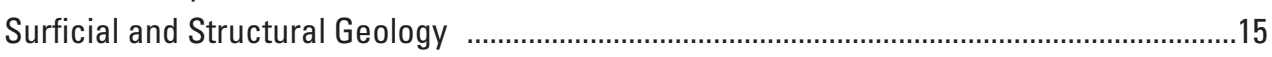

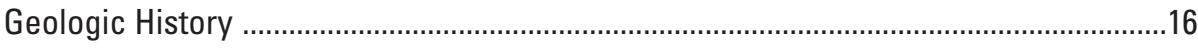

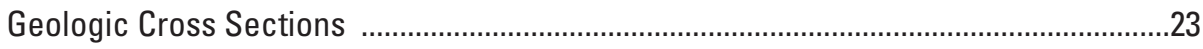

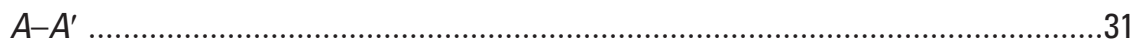

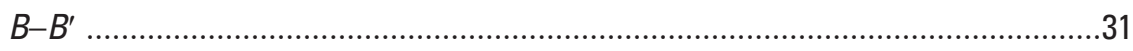

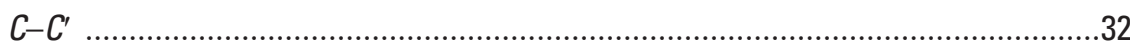

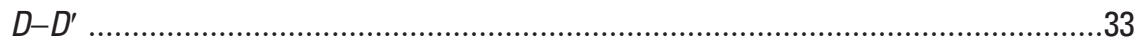

General Stratigraphic and Hydrogeologic Framework in Areas of Interest ...................................34

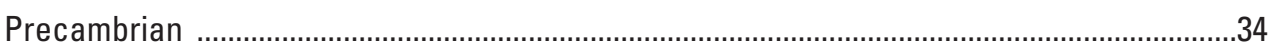

Oil and Gas Potential ...........................................................................................

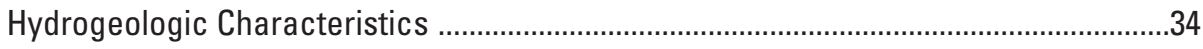

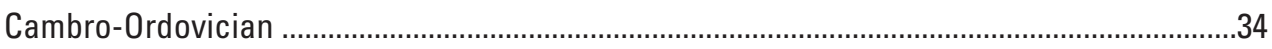

Oil and Gas Potential ............................................................................................

Hydrogeologic Characteristics .............................................................................

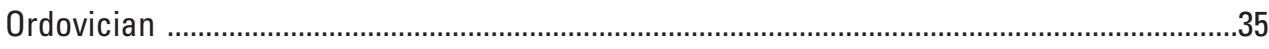

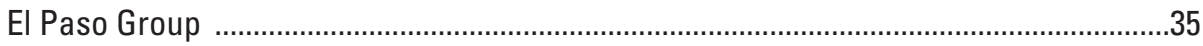

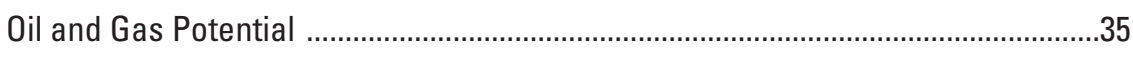

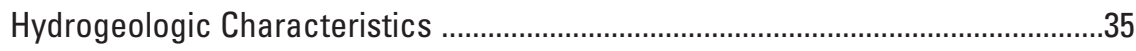




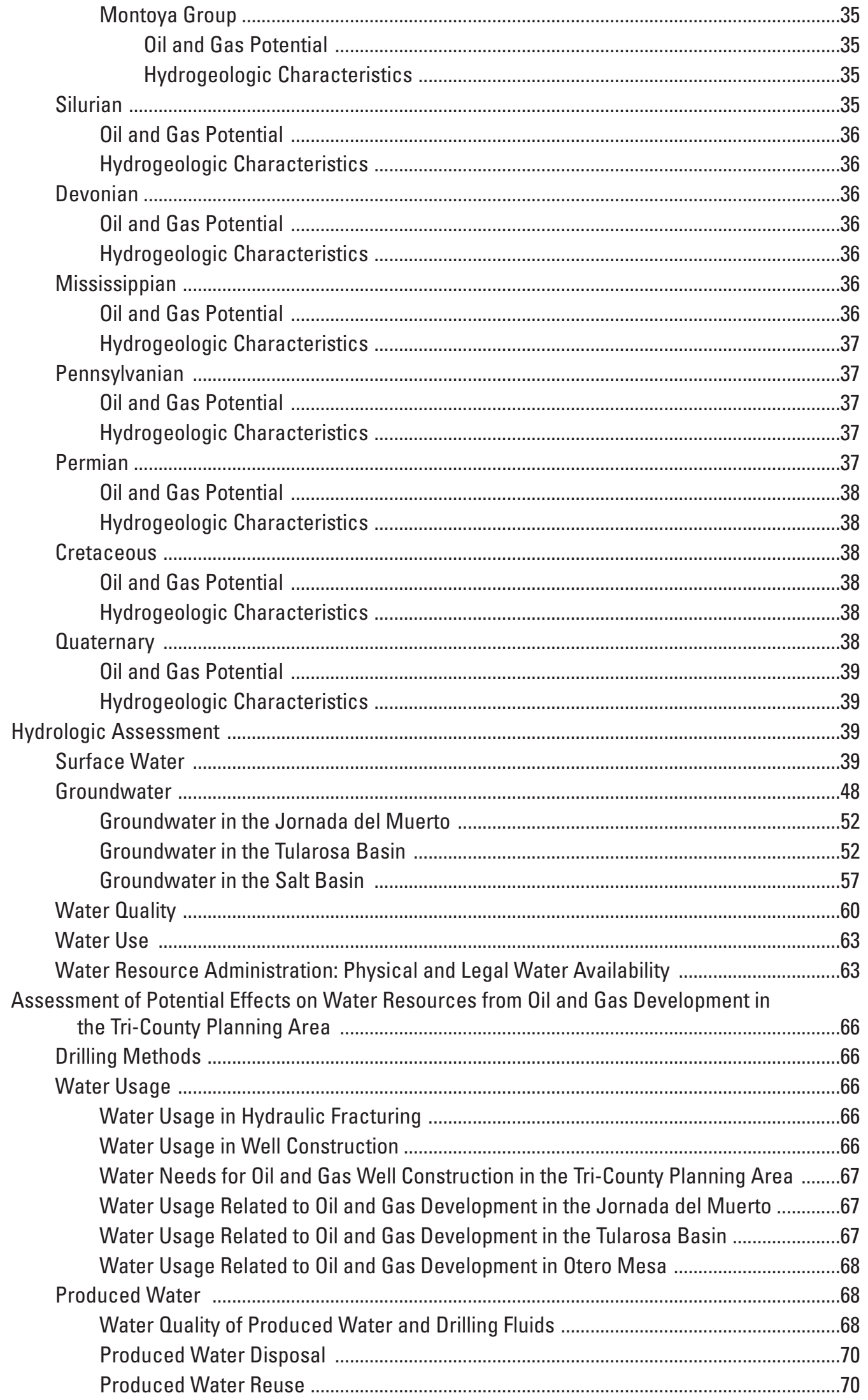


Vulnerability of Groundwater and Surface Water in the Tri-County Planning Area ...............71 Jornada del Muerto ..........................................................................................................

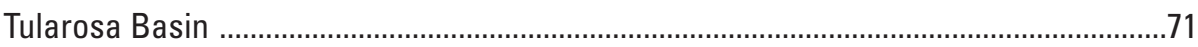

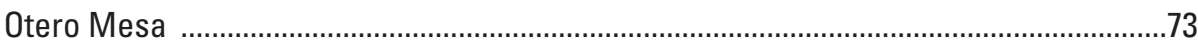

Vulnerability in Doña Ana County .....................................................................................

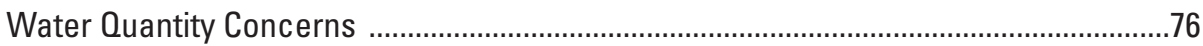

Data Gaps Identified and Suggestions for Further Study ................................................................76

Assessment of Surface-Water Resources ........................................................................

Assessment of Groundwater Resources ..............................................................................

Assessment of Water Quality ...................................................................................................

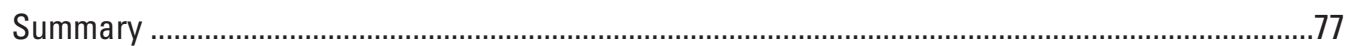

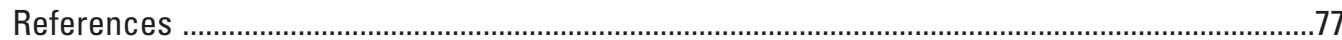

\section{Figures}

1. Map showing lands owned by the Bureau of Land Management (BLM) in the Tri-County planning area, New Mexico

2. Map showing locations of crystalline rocks and oil and gas occurrence potential based on the Bureau of Land Management report on reasonable foreseeable development potential, Tri-County planning area, New Mexico

3. Map showing locations of conventional oil and gas development potential, coalbed gas development potential, and locations of oil and gas wells, Tri-County planning area, New Mexico, 2015

4. Map showing the surficial geology of the Tri-County planning area, New Mexico and the locations of four east-west-oriented geologic cross sections

5. Map showing average annual precipitation in the Tri-County planning area,

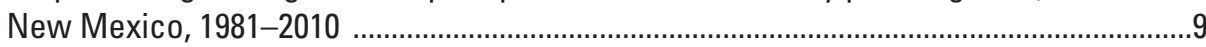

6. Map showing ecoregions in the Tri-County planning area, New Mexico.......................11

7. Map showing locations of basins and mountain ranges and other features in the Tri-County planning area, New Mexico ……………………………………….....12

8. Chart showing divisions of geologic time ……….....................................................13

9. Maps showing locations of geologic cross sections, areas of potential oil and gas occurrence, and wells with logs

10. Geologic cross sections in the Tri-County planning area, New Mexico .........................18

11. Map showing the Tri-County planning area and 8-digit hydrologic unit code (HUC8) watershed boundaries

12. Map showing locations of U.S. Geological Survey streamgages and discrete discharge measurements, Tri-County study area, New Mexico, 2015

13. Map showing locations of U.S. Geological Survey streamgages in the Tri-County planning area, New Mexico

14. Graph showing periods of record for the 15 U.S. Geological Survey continuousrecord streamgages in Sierra, Doña Ana, and Otero Counties, New Mexico, 1920 through September 30, 2015

15. Graphs showing discharge duration curves for 15 continuous-record streamgages in the Tri-County planning area, New Mexico

16. Map showing groundwater basins, the Sacramento Mountains, Otero Break, and Salt Flats in the Tri-County planning area as delineated by the New Mexico Office of the State Engineer 
17. Map showing general groundwater levels in the Tri-County planning area, based on available data in the area, 1967-2017

18. Map showing general groundwater levels and general flow paths in the Jornada del Muerto area, New Mexico

19. Hydrographs showing depth to water in two groundwater wells in the Jornada del Muerto, Sierra County, New Mexico

20. Map showing general groundwater levels and general flow paths in the Tularosa Basin area, New Mexico

21. Hydrographs showing depths to water in two groundwater wells in the Tularosa Basin, Otero County, New Mexico

22. Map showing general groundwater levels and general flow paths in the Otero Mesa and Salt Basin areas, New Mexico

23. Hydrographs showing depths to water in groundwater wells in the Otero Mesa and Salt Basin areas, New Mexico

24. Map showing distribution of total dissolved solids concentrations in surface water in the Tri-County planning area, New Mexico, 1986-2016

25. Map showing distribution of total dissolved solids concentrations in groundwater in the Tri-County planning area, New Mexico, 1986-2016

26. Graphs showing self-supplied domestic water use and mining water use by county from 1990 to 2010, Tri-County planning area, New Mexico

27. Map showing distribution of total dissolved solids (TDS) concentrations in produced water from oil and gas extraction activities near the Tri-County planning area

28. Map showing locations and depths of oil and gas wells, locations of groundwater wells, and ranges of groundwater levels near the Jornada del Muerto, New Mexico

29. Map showing locations and depths of oil and gas wells, locations of groundwater wells, and ranges of groundwater levels near the Tularosa Basin, New Mexico

30. Map showing locations and depths of oil and gas wells, locations of groundwater wells, and ranges of groundwater levels near Otero Mesa, New Mexico

\section{Tables}

1. Summary of hydrostratigraphic nomenclature and description of rock units in areas of interest, Jornada del Muerto, Tularosa Basin, and Otero Mesa, New Mexico

2. Summary statistics for continuous-record streamgages in the Tri-County planning area, New Mexico

3. Oil, gas, and coalbed methane well potential-development estimates with groundwater level data and hydrocarbon occurrence depths related by areas in the Tri-County planning area, New Mexico

4. Total dissolved solids range for freshwater, brackish water, saline water, and brine

5. Water use in Sierra, Doña Ana, and Otero Counties, New Mexico, 2010 .....................63

6. Water-use availability in Sierra, Doña Ana, and Otero Counties, New Mexico 


\section{Conversion Factors}

U.S. customary units to International System of Units

\begin{tabular}{|c|c|c|}
\hline Multiply & By & To obtain \\
\hline \multicolumn{3}{|c|}{ Length } \\
\hline inch (in.) & 2.54 & centimeter $(\mathrm{cm})$ \\
\hline inch (in.) & 25.4 & millimeter $(\mathrm{mm})$ \\
\hline foot $(\mathrm{ft})$ & 0.3048 & meter $(\mathrm{m})$ \\
\hline mile (mi) & 1.609 & kilometer $(\mathrm{km})$ \\
\hline yard (yd) & 0.9144 & meter $(\mathrm{m})$ \\
\hline \multicolumn{3}{|c|}{ Area } \\
\hline acre & 4,047 & square meter $\left(\mathrm{m}^{2}\right)$ \\
\hline acre & 0.4047 & hectare (ha) \\
\hline acre & 0.4047 & square hectometer $\left(\mathrm{hm}^{2}\right)$ \\
\hline acre & 0.004047 & square kilometer $\left(\mathrm{km}^{2}\right)$ \\
\hline $\begin{array}{l}\text { section ( } 640 \text { acres or } 1 \text { square } \\
\text { mile) }\end{array}$ & 259.0 & square hectometer $\left(\mathrm{hm}^{2}\right)$ \\
\hline square mile $\left(\mathrm{mi}^{2}\right)$ & 259.0 & hectare (ha) \\
\hline square mile $\left(\mathrm{mi}^{2}\right)$ & 2.590 & square kilometer $\left(\mathrm{km}^{2}\right)$ \\
\hline \multicolumn{3}{|c|}{ Volume } \\
\hline gallon (gal) & 0.003785 & cubic meter $\left(\mathrm{m}^{3}\right)$ \\
\hline gallon (gal) & 3.785 & cubic decimeter $\left(\mathrm{dm}^{3}\right)$ \\
\hline million gallons (Mgal) & 3,785 & cubic meter $\left(\mathrm{m}^{3}\right)$ \\
\hline acre-foot (acre-ft) & 1,233 & cubic meter $\left(\mathrm{m}^{3}\right)$ \\
\hline acre-foot (acre-ft) & 0.001233 & cubic hectometer $\left(\mathrm{hm}^{3}\right)$ \\
\hline \multicolumn{3}{|c|}{ Flow rate } \\
\hline acre-foot per year (acre-ft/yr) & 1,233 & cubic meter per year $\left(\mathrm{m}^{3} / \mathrm{yr}\right)$ \\
\hline acre-foot per year (acre-ft/yr) & 0.001233 & cubic hectometer per year $\left(\mathrm{hm}^{3} / \mathrm{yr}\right)$ \\
\hline foot per year ( $\mathrm{ft} / \mathrm{yr})$ & 0.3048 & meter per year $(\mathrm{m} / \mathrm{yr})$ \\
\hline cubic foot per second $\left(\mathrm{ft}^{3} / \mathrm{s}\right)$ & 0.02832 & cubic meter per second $\left(\mathrm{m}^{3} / \mathrm{s}\right)$ \\
\hline \multicolumn{3}{|c|}{ Transmissivity } \\
\hline foot squared per day $\left(\mathrm{ft}^{2} / \mathrm{d}\right)$ & 0.09290 & meter squared per day $\left(\mathrm{m}^{2} / \mathrm{d}\right)$ \\
\hline
\end{tabular}

International System of Units to U.S. customary units

\begin{tabular}{llll}
\hline \multicolumn{1}{c}{ Multiply } & By & To obtain \\
\hline meter $(\mathrm{m})$ & Length & \\
kilometer $(\mathrm{km})$ & 3.281 & foot $(\mathrm{ft})$ & mile (mi) \\
meter $(\mathrm{m})$ & 0.6214 & yard (yd) \\
\hline \multicolumn{2}{c}{ Area } & \\
\hline square meter $\left(\mathrm{m}^{2}\right)$ & 1.094 & acre \\
\hline
\end{tabular}


Temperature in degrees Celsius $\left({ }^{\circ} \mathrm{C}\right)$ may be converted to degrees Fahrenheit $\left({ }^{\circ} \mathrm{F}\right)$ as follows:

$$
{ }^{\circ} \mathrm{F}=\left(1.8 \times{ }^{\circ} \mathrm{C}\right)+32 .
$$

Temperature in degrees Fahrenheit $\left({ }^{\circ} \mathrm{F}\right)$ may be converted to degrees Celsius $\left({ }^{\circ} \mathrm{C}\right)$ as follows:

$$
{ }^{\circ} \mathrm{C}=\left({ }^{\circ} \mathrm{F}-32\right) / 1.8 \text {. }
$$

\section{Datum}

Vertical coordinate information is referenced to the North American Vertical Datum of 1988 (NAVD 88).

Horizontal coordinate information is referenced to the North American Albers Datum of 1983 (NADAlbers 83).

Horizontal coordinate information for cross sections is referenced to the North American Datum of 1983 (NAD 83).

Altitude, as used in this report, refers to distance above the vertical datum.

\section{Supplemental Information}

Concentrations of chemical constituents in water are given in milligrams per liter (mg/L).

\section{Abbreviations}

$\begin{array}{ll}\text { API } & \text { American Petroleum Institute } \\ \text { BLM } & \text { Bureau of Land Management } \\ \text { EPA } & \text { U.S. Environmental Protection Agency } \\ \text { HCUWD\#1 } & \text { Hudspeth County Underground Water District No. 1 } \\ \text { HUC8 } & \text { Eight-digit hydrologic unit code } \\ \text { Ma } & \text { Mega-annum } \\ \text { NMBGMR } & \text { New Mexico Bureau of Geology and Mineral Resources } \\ \text { NMOCD } & \text { New Mexico Oil Conservation Division } \\ \text { NMOSE } & \text { New Mexico Office of the State Engineer } \\ \text { NWIS } & \text { National Water Information System (USGS) } \\ \text { RFDS } & \text { Reasonably foreseeable development scenario } \\ \text { TDS } & \text { Total dissolved solids } \\ \text { USGS } & \text { U.S. Geological Survey } \\ \text { UTM } & \text { Universal Transverse Mercator }\end{array}$




\title{
Assessment of Water Resources and the Potential Effects from Oil and Gas Development in the Bureau of Land Management Tri-County Planning Area, Sierra, Doña Ana, and Otero Counties, New Mexico
}

\author{
By Johanna M. Blake, ${ }^{1}$ Keely Miltenberger, ${ }^{1}$ Anne Stewart, ${ }^{1}$ Andre Ritchie,, Jennifer Montoya, ${ }^{2}$ Corey Durr, ${ }^{2}$ \\ Amy McHugh, ${ }^{1}$ and Emmanuel Charles ${ }^{1}$
}

\section{Abstract}

The U.S. Geological Survey (USGS), in cooperation with the Bureau of Land Management, conducted a study to assess the water resources and potential effects on the water resources from oil and gas development in the Tri-County planning area, Sierra, Doña Ana, and Otero Counties, New Mexico. Publicly available data were used to assess these resources and effects and to identify data gaps in the TriCounty planning area.

The Tri-County planning area includes approximately 9.3 million acres and is within the eastern extent of the Basin and Range Province, which consists of mountain ranges and low elevation basins. Three specific areas of interest within the Tri-County planning area are the Jornada del Muerto, Tularosa Basin, and Otero Mesa, which is adjacent to the Salt Basin. Surface-water resources are limited in the Tri-County planning area, with the Rio Grande as the main perennial river flowing from north to south through Sierra and Doña Ana Counties. The Tularosa Creek is an important surface-water resource in the Tularosa Basin. The Sacramento River, which flows southeast out of the Sacramento Mountains, is an important source of recharge to aquifers in the Salt Basin. Groundwater resources vary in aquifer type, depth to water, and water quality. For example, the Jornada del Muerto, Tularosa Basin, and Salt Basin each have shallow and deep aquifer systems, and water can range from freshwater, with less than 1,000 milligrams per liter $(\mathrm{mg} / \mathrm{L})$ of total dissolved solids, to brine, with greater than $35,000 \mathrm{mg} / \mathrm{L}$ of total dissolved solids. Water quality in the Tri-County planning area is affected by the dissolution of salt deposits and evaporation which are common in arid regions such as southern New Mexico.

The potential for oil and gas development exists in several areas within the Tri-County area. As many as 81 new conventional wells and 25 coalbed natural gas wells could be developed by 2035. Conventional oil and gas well construction in the Tri-County planning area is expected to

${ }^{1}$ U.S. Geological Survey.

${ }^{2}$ Bureau of Land Management. require 1.53 acre-feet (acre-ft) $(500,000$ gallons) of water per well, similar to requirements in the nearby Permian Basin of New Mexico, while construction of unconventional wells is expected to require 7.3 acre-ft of water per well. Produced waters in the Permian Basin have high total dissolved solids, in the brackish to brine range.

Data gaps identified in this study include the limited detailed data on surface-water resources, the lack of groundwater data in areas of interest, and the lack of water chemistry data related to oil and gas development issues. Surface waters in the Tri-County planning area are sparse; some streams are perennial, and most are ephemeral. A more detailed study of the ephemeral channels and their interaction with groundwater could provide a better understanding of the importance of these surface-water resources. Groundwater data used in this study are from the USGS National Water Information System, which does not have continuous waterlevel depth data at many of the sites in the Tri-County planning area. On Otero Mesa, no recurrent groundwaterlevel data are available at any one site. The water-quality data compiled in this study provide a good overview of the general chemistry of groundwater in the Tri-County planning area. To fully understand the groundwater resources, it would be helpful to have more wells in specific areas of interest for groundwater-level and water-quality measurements.

\section{Introduction}

The surface-water and groundwater resources of the Tri-County planning area (Sierra, Doña Ana, and Otero Counties, New Mexico; fig. 1) are relied upon to meet existing domestic, agricultural, livestock, and industrial uses. The Tri-County planning area is approximately 9.3 million acres of Federal, State, private, and Tribal lands, and the total surface area managed by the Bureau of Land Management (BLM) is approximately 2.8 million acres, or 30 percent of the total planning area (BLM, 2013). The BLM-owned areas with specific interest to the BLM in regards to oil and gas development are named "areas of interest" henceforth. 


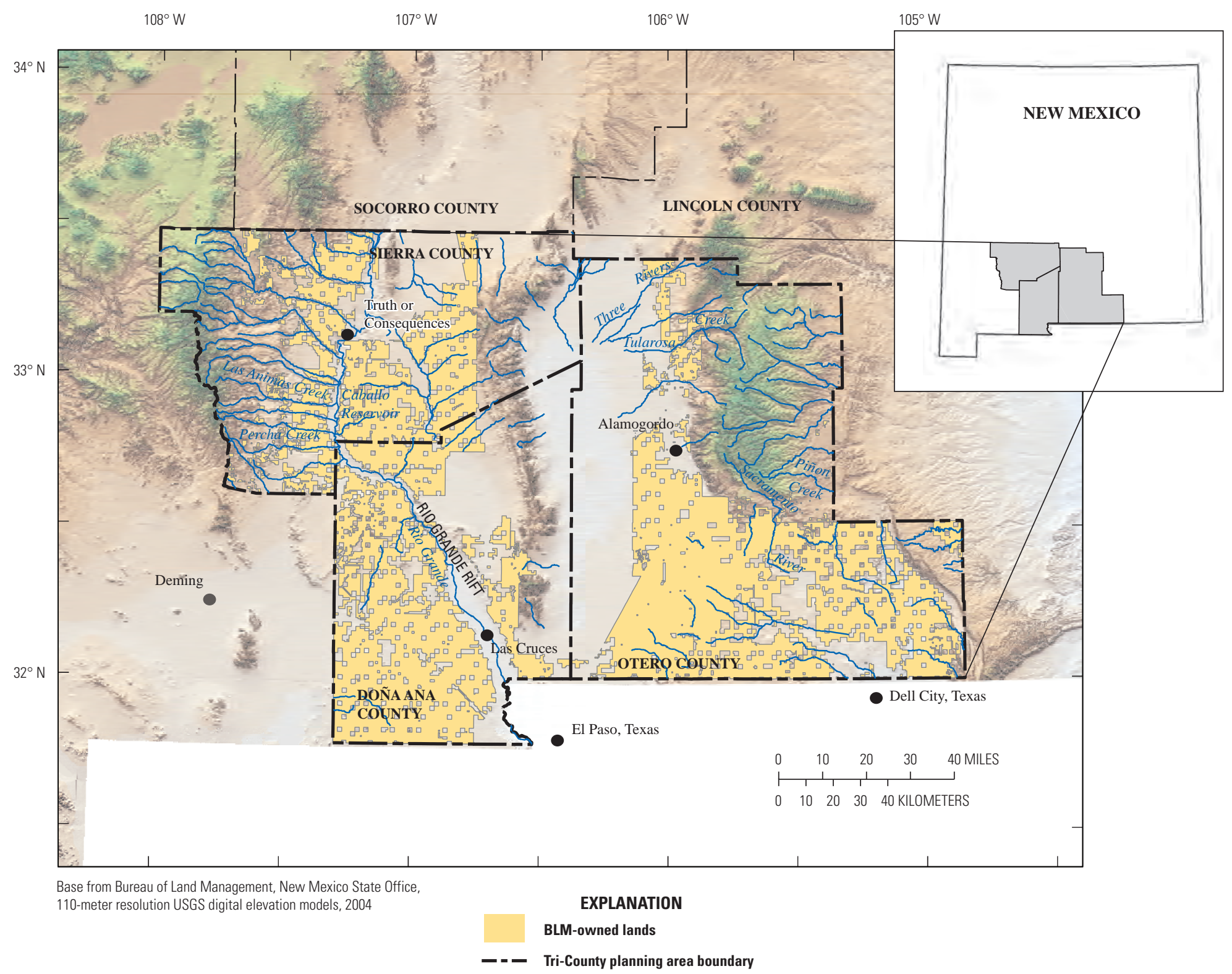

Figure 1. Lands owned by the Bureau of Land Management (BLM) in the Tri-County planning area, New Mexico. 
The three areas of interest are the Jornada del Muerto, the Tularosa Basin, and Otero Mesa, which often includes the Salt Basin (fig. 2).

Development of oil and gas resources on BLM lands within the Tri-County planning area may add to the water needs of the area and may affect water quality. Many published studies on the hydrogeology and water resources have been conducted within the planning area (for example, Bjorklund, 1957; Angles, 2001; Huff and Chace, 2006; and Ritchie, 2011), but few studies have been done at a scale that would allow the BLM to understand potential effects of their planning decisions across all three of the counties (Brady and others, 1983; Bedinger and others, 1989), and few studies have focused on the possible effects of oil and gas development on water resources in the area.

In 2013, the BLM released its Tri-County Resource Management Plan/Draft Environmental Impact Statement for public comment (BLM, 2013). Based on public comment, the BLM concluded that a supplemental environmental impact statement about analyzing alternatives for fluid minerals, such as oil and gas, leasing in the three counties was warranted. The planning area contains hydrologically connected and closed surface-water and groundwater basins, some of which cross State and National boundaries, with competing water demands for remote and populated areas in New Mexico, Texas, and Mexico. Some parts of the decision area are multiple-use lands, while others have varying levels of resource protections, including Areas of Critical Environmental Concern and Wilderness Study Areas.

In 2016, the U.S. Geological Survey (USGS), in cooperation with the BLM, initiated an assessment of the hydrology and potential effects of oil and gas development in the Tri-County planning area. An enhanced understanding of water uses across the planning area and an understanding of the possible effects of oil and gas development on the Jornada del Muerto, the Tularosa Basin, the Salt Basin, and Otero Mesa (fig. 2) are needed for the BLM planning process. Each of these areas of interest contain potable water that is sensitive to water quantity and (or) quality issues related to oil and gas development.

A limited amount of oil and gas development has occurred in the Tri-County planning area thus far (fig. 3), especially in comparison to the oil and gas development in the Permian Basin in New Mexico, located due east of the study area. The Permian Basin has been extensively developed for oil and gas production. As of 2009, BLM records show that 10,738 wells had been drilled on BLM lands in the Permian Basin (BLM, 2014), whereas in the Tri-County planning area, only 126 oil and gas wells had been drilled by 2015 , and only 6 of those remained active in 2015 (Glover, 2015). The Permian Basin is approximately 43 million acres compared to 9.3 million acres of the Tri-County planning area. In addition to the larger size of the Permian Basin, more traces of oil and gas appear in the Permian Basin than in the Tri-County planning area. The Reasonable Foreseeable Development Scenario for Oil and Gas Activities in the Tri-County Planning Area, South-Central New Mexico (RFDS) published by
BLM (Glover, 2015) provides details on the known wells drilled in the planning area and on the occurrence potential (fig. 2) and development potential (fig. 3) for oil and gas. The RFDS identifies areas of oil and gas occurrence potential by using historical and geological parameters. Such areas were identified for the Tri-County planning area by using the known geology and history of the nearby Permian Basin. The RFDS defines areas of "reasonably-foreseeable development potential" as a subset of potential oil and gas activity areas identified by the baseline scenario, considering limitations to development by "management-imposed conditions." The baseline scenario describes the likely anticipated oil and gas activity in the area based on historical and geological parameters. Management-imposed conditions could include administrative or economic constraints (Glover, 2015).

The RFDS lists areas with the highest potential for hydrocarbon development (fig. 3). This study includes information on water resources and geology of the Tri-County planning area in a broad sense and focuses on the Jornada del Muerto, Tularosa Basin, and Otero Mesa in relation to water quality and quantity (fig. 2), which are areas with the most recent leasing and drilling activity. The RFDS projects that 81 new conventional oil and gas wells and 25 coalbed natural gas wells could potentially be drilled in the planning area during 2015-2035 (figs. 2 and 3; Glover, 2015). This report provides a broad overview of the geology and hydrology of the Tri-County planning area as well as more detailed assessments of the three areas of interest to support BLM management decisions in the area. The discussion of geology is extensive in this report to clearly define the framework of the structure and types of rocks found in the Tri-County planning area. This information is important for understanding how water resources could be affected by oil and gas development and to provide information on the known oil and gas reservoirs or shows (indicators of oil and gas).

\section{Purpose and Scope}

This report presents the results of the initial assessment of water resources in the Tri-County planning area. The overall objectives of this study are to improve the existing characterization of surface-water and groundwater resources across the Tri-County planning area and provide hydrologic information related to potential oil and gas development. This report contains

1. A compilation of published literature and existing data related to water resources.

2. Results of an assessment of the vulnerability of water resources to potential effects of oil and gas development within the Tri-County planning area.

3. Discussion of critical gaps in hydrologic data necessary for informed management of water resources.

A geodatabase with shapefiles containing data related to water resources, water quality, and oil and gas development 
$\begin{array}{llll}108^{\circ} \mathrm{W} & 107^{\circ} \mathrm{W} & 106^{\circ} \mathrm{W} & 105^{\circ} \mathrm{W}\end{array}$

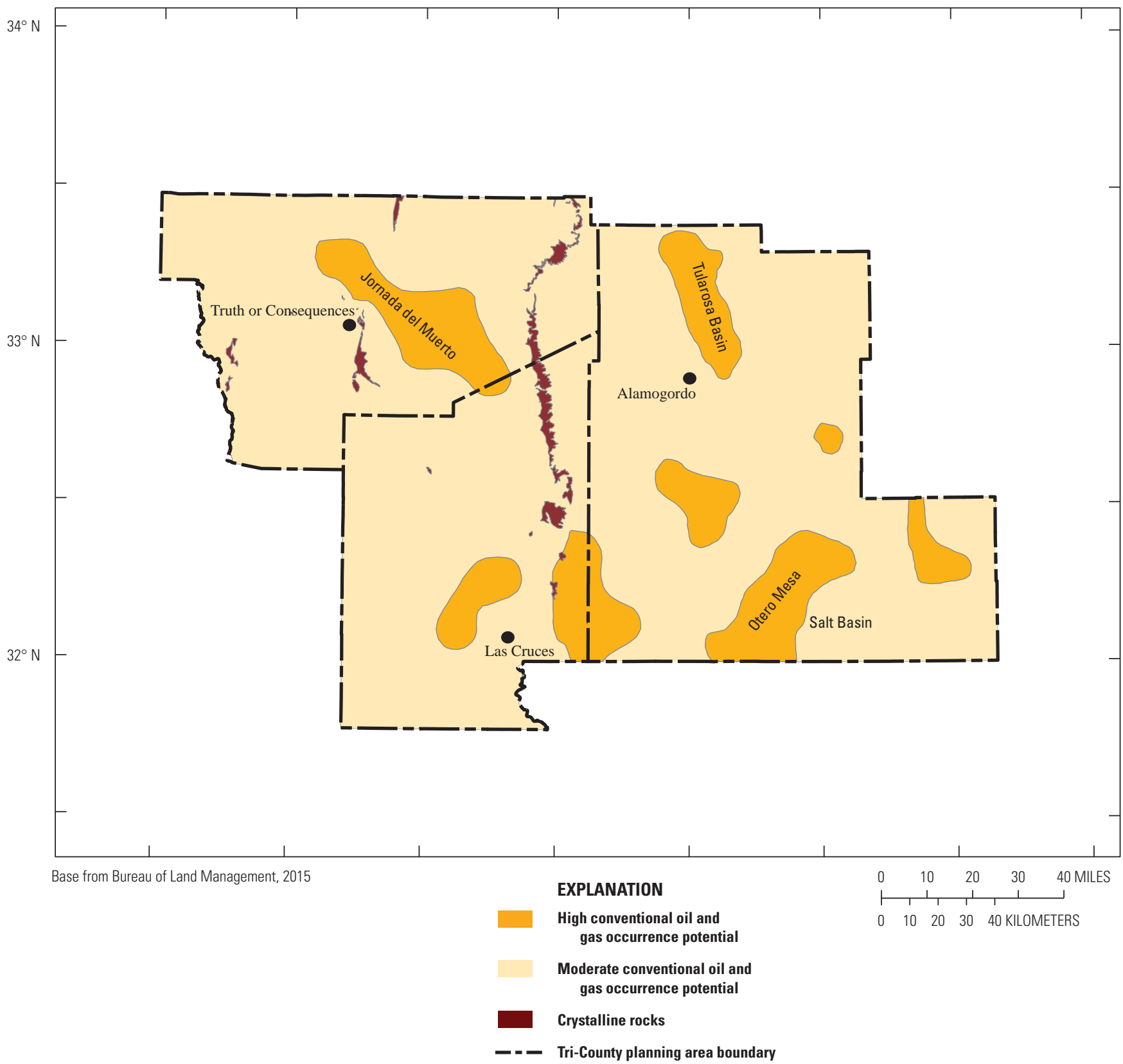

Figure 2. Locations of crystalline rocks and oil and gas occurrence potential based on the Bureau of Land Management report on reasonable foreseeable development potential, Tri-County planning area, New Mexico (Glover, 2015). 


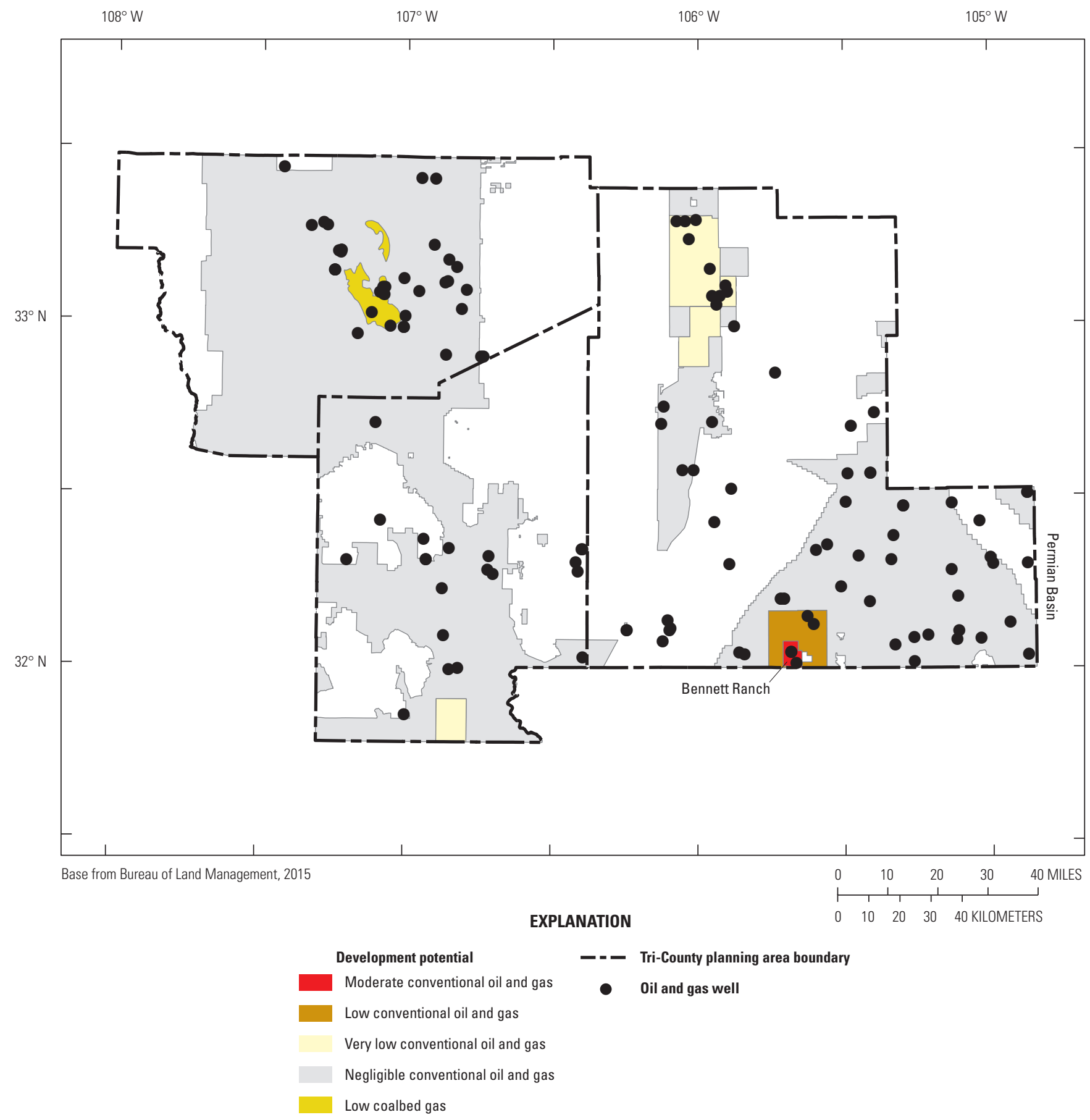

Figure 3. Locations of conventional oil and gas development potential, coalbed gas development potential, and locations of oil and gas wells, Tri-County planning area, New Mexico, 2015 (Glover, 2015). 
accompanies this study to provide additional resources to aid the BLM in management decisions (Blake and others, 2017). The geodatabase also contains metadata for each shapefile attribute.

\section{Methods}

Current understanding of the water resources and potential effects from oil and gas development in the TriCounty planning area was summarized from review of available literature and publically available data on geology, surface water, groundwater, and water quality and foreseeable oil and gas development scenarios. A field study was not conducted. Various lithologic identifications or formation names from other regions were previously used in petroleum exploratory drill logs. These were correlated and corrected to current New Mexico nomenclature by using Geolex (USGS, 2017a) and the National Geologic Map Database (USGS, 2017b).

\section{Geologic Data}

Four east-west-oriented geologic cross sections spanning the overall north-south extent of the Tri-County planning area were created by modifying previously published geologic cross sections from Bedinger and others (1989), Hawley and Kennedy (2004), and Ritchie (2011) (fig. 4). Cross sections $A-A^{\prime}, B-B^{\prime}$, and $C-C^{\prime}$ from Plate 2 of Bedinger and others (1989); I-I' from Plate 2 of Hawley and Kennedy (2004); and $C-C^{\prime}$ and $E-E^{\prime}$ from Ritchie (2011) were digitized in ArcGIS 10.3.1 (Esri, 2015) and modified by incorporating surface and subsurface geologic unit thickness information from oil and gas exploratory wells, surface geologic unit outcrop location information along each cross-section line, and surface and subsurface fault locations and relative displacement across faults.

Cross sections $A-A^{\prime}$ and $B-B^{\prime}$ created for this study were based on cross sections $A-A^{\prime}$ and $B-B^{\prime}$ from Bedinger and others (1989), and the plan-view extent of these cross sections replicated the Bedinger and others (1989) cross sections. Cross section $C-C^{\prime}$ created for this study was based on cross section $C-C^{\prime}$ from Ritchie (2011) that covered the eastern part of Otero County and data compiled for this study for the western part of Otero County and Doña Ana County. Cross section $D-D$ ' created for this study was based on cross section $E-E^{\prime}$ from Ritchie (2011), which covered the eastern part of Otero County; cross section C $-C^{\prime}$ from Bedinger and others (1989), which covered the western part of Otero County and the eastern part of Doña Ana County; and cross section I-I' from Hawley and Kennedy (2004), which covered the central and western parts of Doña Ana County.

Subsurface geologic unit thickness information was obtained from a variety of sources, including depths to geologic unit tops in oil and gas exploratory wells as documented in well files from the New Mexico Oil Conservation Division (NMOCD; 2016a); as reported in Kottlowski and others (1969), Thompson and Bieberman (1975), and Lozinsky (1987); and as reported by the New Mexico Bureau of Geology and Mineral Resources (NMBGMR) (A. Trivitt-Kracke, written commun., July 20, 2016). Thickness of geologic units in oil and gas exploratory wells was reported in Kottlowski $(1963,1965)$. Surface geologic unit outcrop location information was obtained from the NMBGMR Geologic Map of New Mexico at 1:500,000 scale (NMBGMR, 2003). Information on surface and subsurface fault locations and relative displacement across faults was obtained from the NMBGMR Geologic Map of New Mexico at 1:500,000 scale (NMBGMR, 2003; Sweetkind and others, 2017) and from the previously published cross sections (Bedinger and others, 1989; Hawley and Kennedy, 2004; Ritchie, 2011).

Some geologic units only had thickness information available in oil and gas exploratory wells as reported in Kottlowski (1963, 1965). For these units, depth to geologic unit picks (for example, top or bottom) were estimated by either adding or subtracting the thickness of geologic units to or from depth to geologic unit tops for units either stratigraphically directly above or below the units with only thickness information. In addition, one depth to geologic unit pick shown on cross section $C-C^{\prime}$ and one depth to geologic unit pick shown on cross section $D-D^{\prime}$ correspond to the total depth of an oil and gas exploratory well because the information compiled indicated these wells were in a specific geologic unit at total depth (Blake and others, 2017). Location information from wells about geologic unit tops and bottoms was obtained from the NMOCD (2016b) and the NMBGMR (A. Trivitt-Kracke, written commun., June 10, 2016). Location information from wells about geologic unit tops and bottoms obtained from the NMOCD was in an ArcGIS shapefile format, using the Universal Transverse Mercator (UTM) coordinate system, zone 13 north, North American Datum of 1983 (NAD 83), in units of meters. Location information obtained from the NMBGMR was in a tabular format, using latitude and longitude geographic coordinates in decimal degrees, with an undefined horizontal datum. The horizontal datum for the NMBGMR location information was assumed to be NAD 83, and locations were converted to the projected coordinate system, UTM zone 13 north, in units of meters to be consistent with the NMOCD location information. Oil and gas exploratory wells are labeled on each cross section with each well's American Petroleum Institute (API) number, whether or not the well was projected, and, if projected, the distance the well was projected. Location coordinates, depth to geologic units made by petroleum geologists from exploratory wells, and data sources for oil and gas exploratory wells displayed on cross sections $A-A^{\prime}$ through $D-D^{\prime}$ are provided in the data release associated with this study (Blake and others, 2017). 


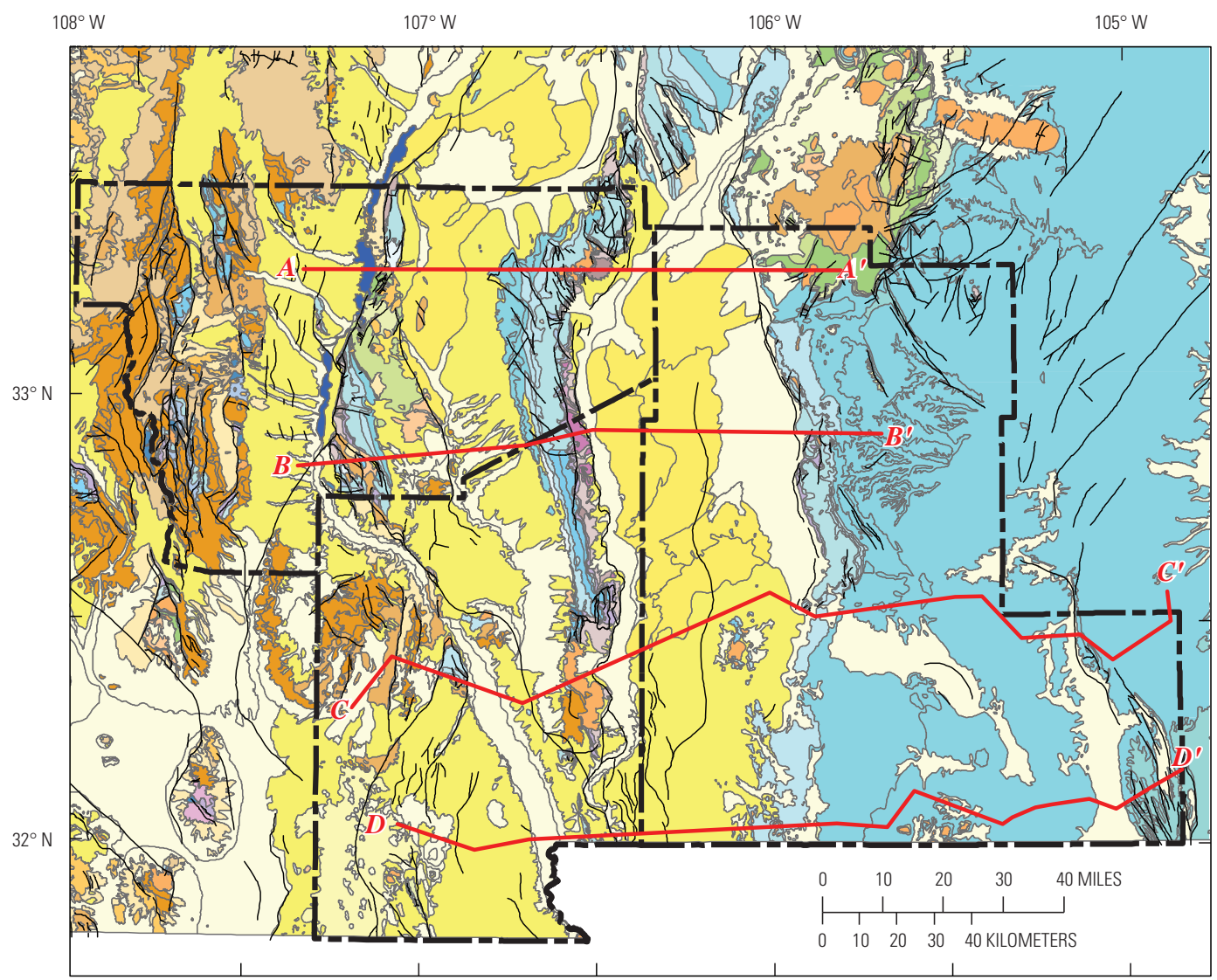

EXPLANATION

Quaternary

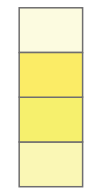

Alluvium and piedmont deposits

Eolian, lacustrine, playa, and gypsiferous eolian deposits Upper Santa Fe Group and Gila Formation deposits Basaltic and andesitic lava flow deposits

Tertiary

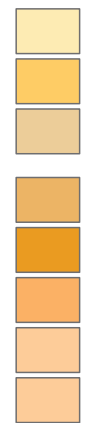

Lower Santa Fe Group deposits

Late Tertiary basaltic and andesitic lava flow deposits

Upper to middle Tertiary silicic to intermediate volcanic rocks rhyolitic lavas, and tuff deposits

Middle Tertiary volcanic rocks and volcaniclastic sedimentary deposits

Tertiary to Cretaceous basaltic andesites, rhyolitic lavas and tuffs, volcanic, andesitic, dacitic, and pyroclastic breccia deposits

Intermediate to silicic intrusive rock deposits

Early Tertiary sedimentary rocks

Cretaceous

Upper, lower, and undivided Cretaceous rocks

Mesa Verde Group

Mancos Shale

Dakota Sandstone

\section{Triassic}

Chinle Formation

Paleozoic

Paleozoic rocks, undivided

Permian rocks, undivided

Permian rocks, Artesia Group and Queen and Grayburg Formations

Permian rocks, San Andres Limestone and Yeso Formation

Permian rocks, Hueco, Abo, and Bursum Formations

Pennsylvanian rocks, undivided

Pennsylvanian rocks, Madera Group, Panther Seep Formation, and Lead Camp Limestone

Mississippian, Devonian, Silurian and Cambrian rocks, undivided

Mississippian through Cambrian rocks, undivided

\section{Proterozoic}

Mesoproterozoic granitic rocks

Paleoproterozoic granitic rocks

Paleoproterozoic mafic, rhyolite, and felsic volcanics and volcanic schist rocks

Paleoproterozoic quartzite rocks

Paleoproterozoic metasedimentary rocks

D-D' Geologic cross section (fig. 10)

Faults

- - Tri-County planning area boundary

Figure 4. The surficial geology of the Tri-County planning area, New Mexico (New Mexico Bureau of Geology and Mineral Resources, 2003) and the locations of four east-west-oriented geologic cross sections. 


\section{Hydrologic Data}

Discrete and continuous surface-water discharge data were obtained from the USGS National Water Information System (NWIS) database (USGS, 2017c) and reviewed for quality control. An inventory of USGS sites which had surface-water flow data in NWIS was obtained to determine surface-water data availability to characterize the hydrology of the study area. All sites within the Tri-County planning area, as well as sites within 1 mile outside of the area boundary, and the data associated with those sites were included in the inventory. Within NWIS, 275 surface-water sites are established within the Tri-County planning area and the 1-mile outer boundary of the planning area, and 197 of these sites have surface-water flow (streamflow) data. Of those 197 sites, 182 only have discrete measurements of streamflow, and 15 sites have continuous streamflow measurements. Measurements from 8 of these 15 sites are associated with annual peak streamflow determinations. The majority of the sites (approximately 140) have only 1 to 3 discrete streamflow measurements on concurrent dates. All surface-water sites are subsequently referred to as streamgages in this report, and some are identified with station numbers. Shapefiles of surface-water data including streamgage locations and discharge data were created in ArcMap 10.3.1 (Esri, 2015) and are accessible through the data release associated with this report (Blake and others, 2017). Time series plots and statistical summaries of continuous record discharges were produced to describe the available surface-water data.

Groundwater-level data were obtained from the USGS NWIS database and reviewed for quality control. Groundwater-level data were sorted by location and aquifer to create time-series plots of depth to groundwater from the surface. Raster files of groundwater-level maps were georeferenced in ArcMap 10.3.1 (Esri, 2015) by using the georeferencing tool, and then shapefiles were made of groundwater elevation contours by tracing the georeferenced raster files and modified based on professional judgement (Blake and others, 2017). Groundwater wells for in-depth analysis were first selected in the Tri-County planning area based on proximity to the areas of interest for high occurrence potential of conventional oil and gas development. Those areas of interest include the Jornada del Muerto, Tularosa Basin, and Otero Mesa/Salt Basin (fig. 2). Sites for in-depth analysis were then selected based on groundwater aquifer sources. Further selections were then made to acquire the greatest amount of historical groundwater-level measurements that are available within the NWIS database.

Water-quality data were obtained from the USGS NWIS database and reviewed for quality control. Quality-control reviews included checking data for approval status, comparing the cation to anion balance, and comparing data among wells. Total dissolved solids (TDS) concentrations, which are used to evaluate water quality in this assessment, are measured as residue on a filter following drying at 180 degrees Celsius, and quality-control reviews are important to ensure data comparability among samples. Additional data were compiled from Mayer (1995), Mamer and others (2014), Newton and Land (2016), and Sigstedt and others (2016). All water-quality data were projected spatially in ArcMap 10.3.1. These data are included with the associated data release for this study (Blake and others, 2017).

To assess the potential effects on water resources from oil and gas development, calculations were made based upon data from the nearby Permian Basin (Engler and Cather, 2014). Water-quality data of produced waters were collected from the USGS National Produced Waters Geochemical Database (USGS, 2016c), and are included in the data release associated with this study (Blake and others, 2017). Each dataset was spatially projected, and the horizontal coordinate information is referenced to the North American Albers Datum of 1983 (NADAlbers 83). Information such as stream locations, groundwater-well locations, and groundwater-level elevations and water-quality data in surface water and groundwater are included in the data release. Additionally, shapefiles of oil and gas occurrence and development potential provided by the BLM (Glover, 2015) are included in the data release to provide the pertinent information in one geodatabase.

\section{Physical Characteristics of the Tri-County Planning Area}

The Tri-County planning area includes approximately 9.3 million acres and consists of Sierra, Doña Ana, and Otero Counties in southern New Mexico (fig. 1; BLM, 2013). This area is varied in climate, ecoregions, geology, water resources, water quality, and oil and gas potential. This section describes these features broadly across the Tri-County planning area as well as at specific locations in the three areas of interest, the Jornada del Muerto, Tularosa Basin, and Otero Mesa.

\section{Climate}

During 1980-2010, the average annual precipitation of the entire Tri-County planning area was 11.2 inches (in.) with a minimum of $2.93 \mathrm{in}$. and a maximum of $29.2 \mathrm{in}$. (New Mexico Office of the State Engineer and the New Mexico Interstate Stream Commission, 2016). The precipitation data from the PRISM Climate Group (2017) shown in figure 5 are for the period 1981 to 2010 , and, according to those data, the maximum annual precipitation is greater than $31 \mathrm{in}$. Higher elevations receive the most precipitation as snowfall in the winter months, and lower elevations receive the least precipitation overall. Moisture in the form of monsoon storms occurs in the summer months. The American southwest is noted for the occurrence of an annual monsoon season which typically spans from early July until the end of September and represents the delivery of a substantial portion of annual precipitation. The mean annual temperatures in New Mexico range from 40 degrees Fahrenheit $\left({ }^{\circ} \mathrm{F}\right)$ in high mountains in the northern part of the State to $64^{\circ} \mathrm{F}$ in the southern part of the State (Western Regional Climate Center, 2017). 
$108^{\circ} \mathrm{W}$

$107^{\circ} \mathrm{W}$ $106^{\circ} \mathrm{W}$

$105^{\circ} \mathrm{W}$

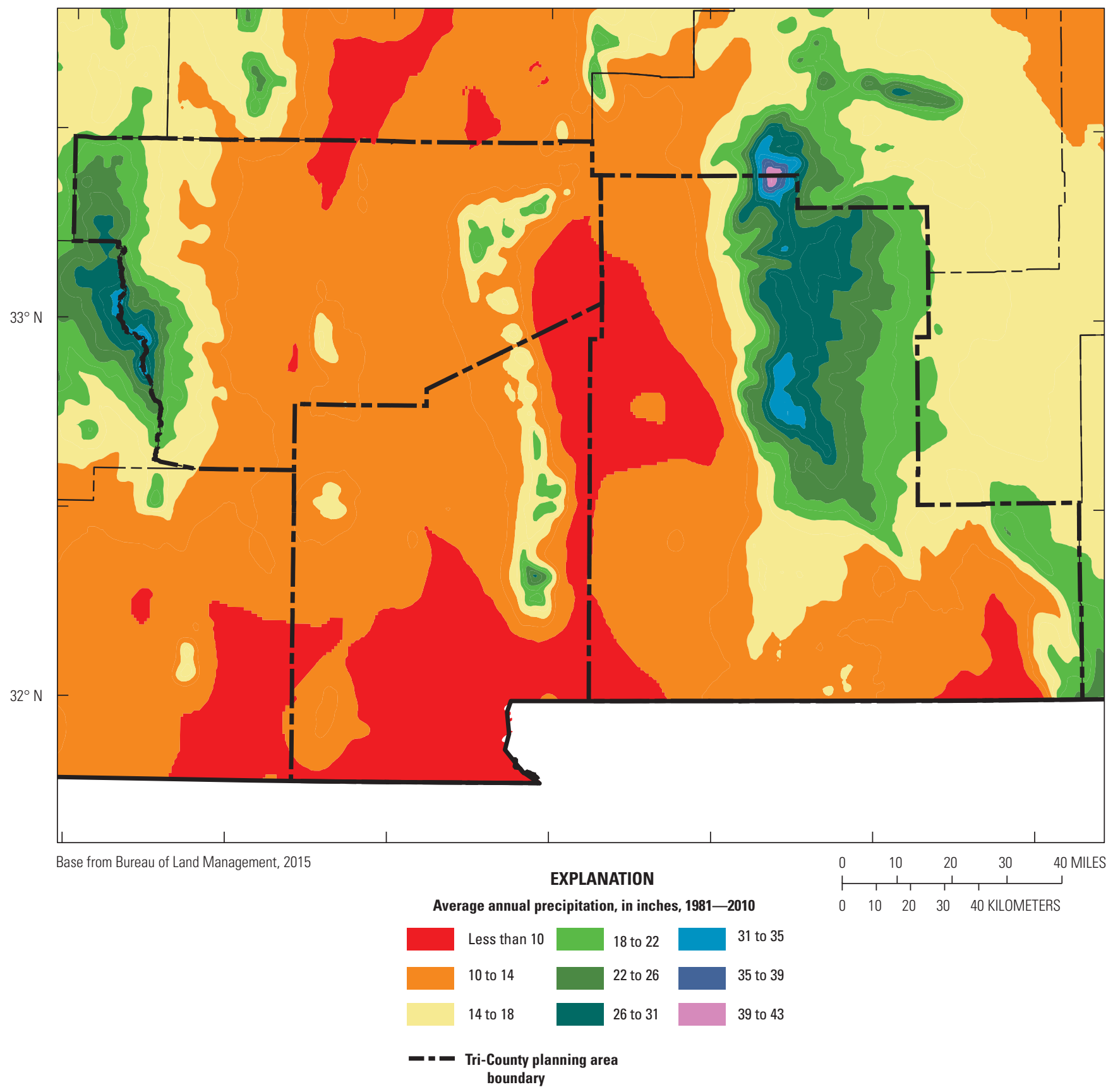

Figure 5. Average annual precipitation in the Tri-County planning area, New Mexico, 1981-2010. (PRISM Climate Group, 2017). 


\section{Vegetation}

The Tri-County planning area falls within the broad description of the Chihuahuan Desert Ecoregion that includes Chihuahuan Desert Slopes, Chihuahuan Desert Grasslands, Chihuahuan Basins and Playas, and Chihuahuan Montane Woodlands (fig. 6; Omernik and Griffith, 2014; U.S. Environmental Protection Agency, 2016a). Lowland features are generally dominated by basins, playas, grasslands, and shrublands. Ascending in elevation, low mountains and bajadas (broad benches or alluvial fans) are shrub dominated, and higher elevation terrains consist of forests, woodlands, and rocky slopes. Vegetation plays an important role for controlling runoff and infiltration in semiarid regions such as the planning area (Dunne and others, 1991). For example, shrubs such as mesquite and creosote bush have invaded large areas of grassland in the southwestern United States, which affects infiltration and runoff (Bhark and Small, 2003).

\section{Physiography and Climate Summaries for Identified Basins and Ranges}

The physiography of the Tri-County planning area is characterized by basins and ranges within the Rio Grande rift and the eastern Basin and Range Province, with northsouth-trending uplifted or tilted mountain ranges separated by alluvial valleys or basins (fig. 7). The land surface of the Tri-County planning area exposes rocks ranging from the Precambrian age that have been uplifted by faulting in the higher elevations to basin-fill sediments of Quaternary age. More detail on the geology of the Tri-County planning area is provided in the Surface and Structural Geology section of this report. Because of orographic affects, highland areas generally receive more precipitation than lowland areas, and precipitation is usually in the form of snow and rainfall. The geologic timescale, which includes major age units, is included as figure 8 for reference.

The Tri-County planning area has 17 basins and ranges: from west to east, Black Range, Palomas Basin, Caballo Mountains (range), Engle Basin, which contains the Elephant Butte Reservoir (basin), West Potrillo Mountains (range), Mesilla Basin-Lower Rio Grande (basin), Jornada del Muerto (basin), San Andres Mountains (range), Organ Mountains (range), Doña Ana Mountains (range), Hueco Bolson (basin), Tularosa Basin, Otero Mesa (range), Cornudas Mountains (range), Salt Basin, Sacramento Mountains (range), and Guadalupe Mountains (range) (fig. 7). These basins and ranges are described briefly in the following sections.

\section{Black Range}

Located in the northwest corner of the Tri-County planning area, the Black Range is a north-south-trending mountain range (fig. 7; Kuellmer, 1954). The range is composed of a thick sequence of volcanic rocks of Tertiary age called the Datil Formation (Ericksen and others, 1970). Rainfall occurs primarily in July and August with annual rainfall ranging from 16 to $30 \mathrm{in}$., depending upon elevation (Ericksen and others, 1970). Snowfall occurs from December through February. Percha Creek and Las Animas Creek (fig. 1) streamflow from the Black Range, through the Palomas Basin, and into the Caballo Reservoir.

\section{Palomas Basin}

Part of the Rio Grande rift, the Palomas Basin (fig. 7) is an east-dipping half graben filled with upwards of 6,500 feet (ft) of basin-fill deposits of the Quaternary-Tertiary Santa Fe Group (Lozinsky, 1987). Annual rainfall ranges from less than 5 to 20 in., with an average of 12.5 in. (Jones and others, 2013).

\section{Caballo Mountains and Engle Basin}

The Caballo Mountains trend north-south between the Palomas Basin and the Jornada del Muerto (fig. 7). Elephant Butte Reservoir is located in the eastern part of the Engle Basin on the western edge of the Caballo mountains. Rock types range in age from Precambrian to Quaternary, with about $17,000 \mathrm{ft}$ of sedimentary rocks underlying the surface. Granite, gneiss, and schist make up 10 percent of the total outcrop area (Silver, 1955). Average annual precipitation at Elephant Butte Reservoir is 10 in. (U.S. Climate Data, 2017). The Rio Grande (fig. 1) flows from Elephant Butte Reservoir into Caballo Reservoir and continues south towards Las Cruces.

\section{West Potrillo Mountains}

The West Potrillo Mountains are part of the Potrillo volcanic field of Quaternary age, which contains olivine basalts (fig. 7; Kilburn and others, 1988; Hoffer, 2001). Approximately 125 individual cinder cone volcanoes have been identified within the West Potrillo Mountains. The area is generally arid, with hot summers and moderate winters.

\section{Mesilla Basin-Lower Rio Grande}

The Mesilla Basin-Lower Rio Grande is located in southern Doña Ana County (fig. 7). Eastern boundaries of the basin are the Doña Ana, Tortugas, Organ, and Franklin Mountains. The basin is filled with Rio Grande flood-plain sediments and fluvial deposits of the Santa Fe Group outside of and below the flood-plain sediments. Average annual rainfall is about 8 in. in the basin (Wilkins, 1986). 
$08^{\circ} \mathrm{W}$

$107^{\circ} \mathrm{W}$

$106^{\circ} \mathrm{W}$

$105^{\circ} \mathrm{W}$
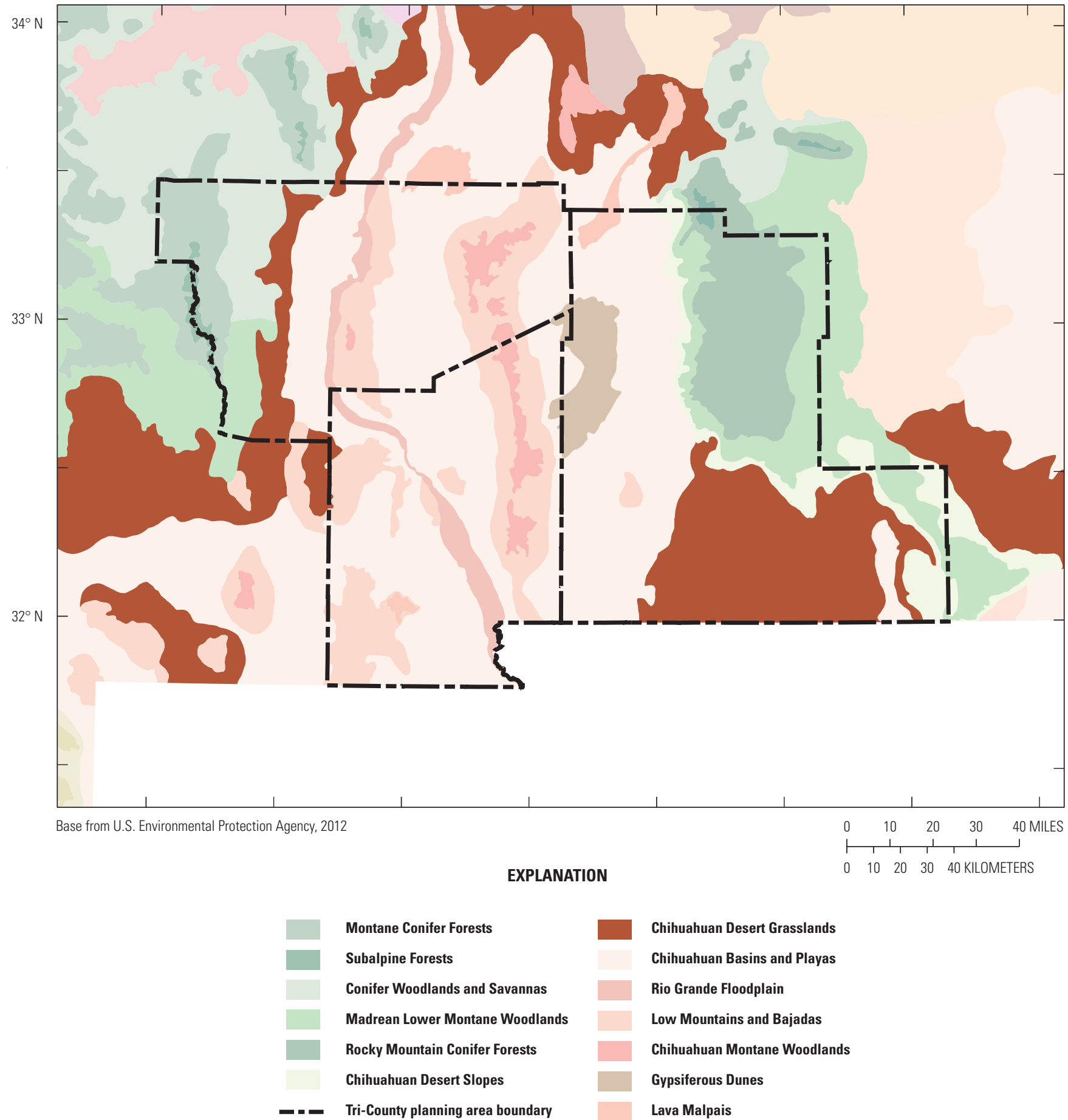

\begin{tabular}{|l|}
\hline Chihuahuan Desert Grasslands \\
Chihuahuan Basins and Playas \\
Rio Grande Floodplain \\
Low Mountains and Bajadas \\
Chihuahuan Montane Woodlands \\
Gypsiferous Dunes \\
Lava Malpais
\end{tabular}

Figure 6. Ecoregions in the Tri-County planning area, New Mexico (U.S. Environmental Protection Agency, 2016a). 


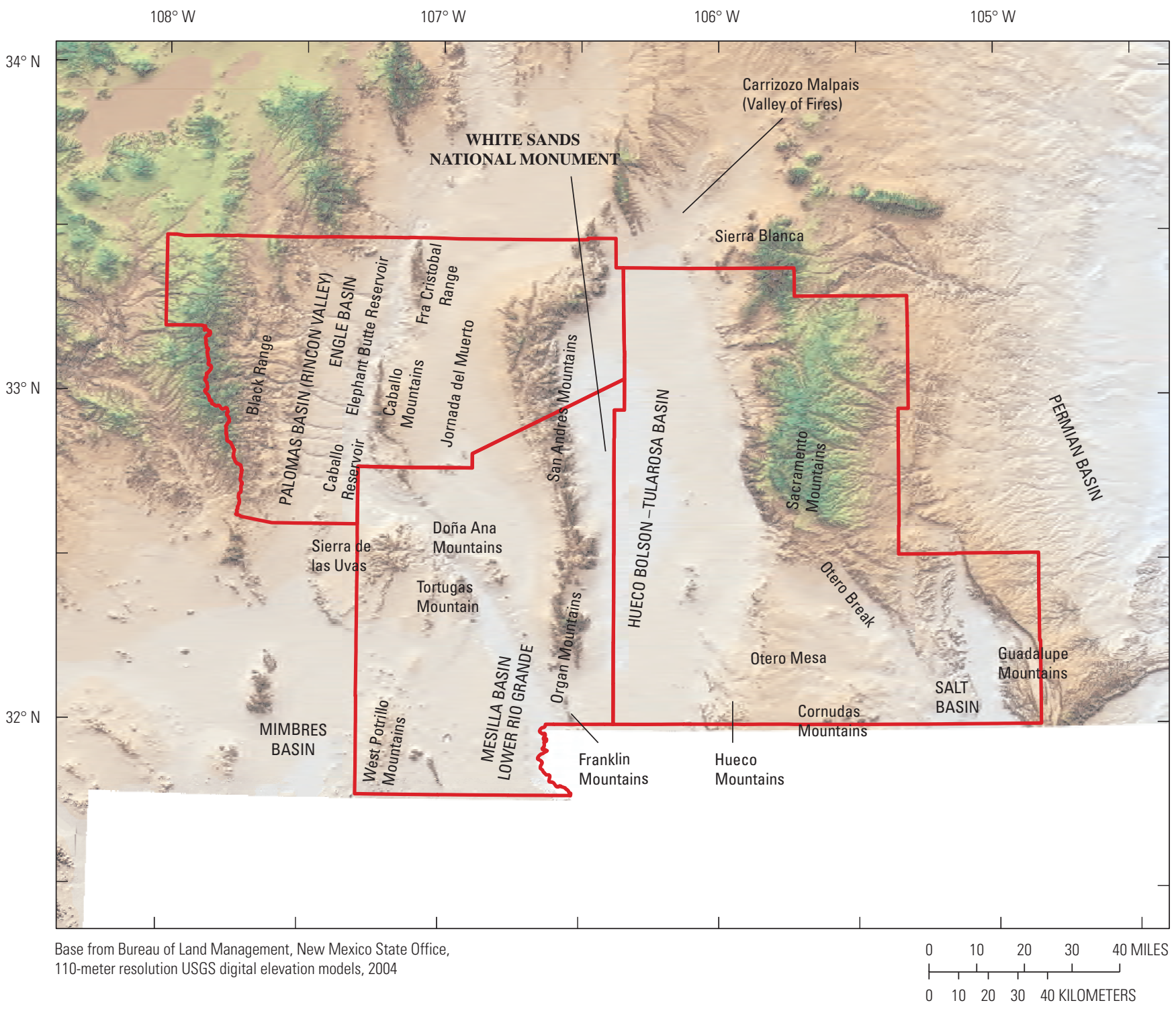

Figure 7. Locations of basins and mountain ranges and other features in the Tri-County planning area, New Mexico. 

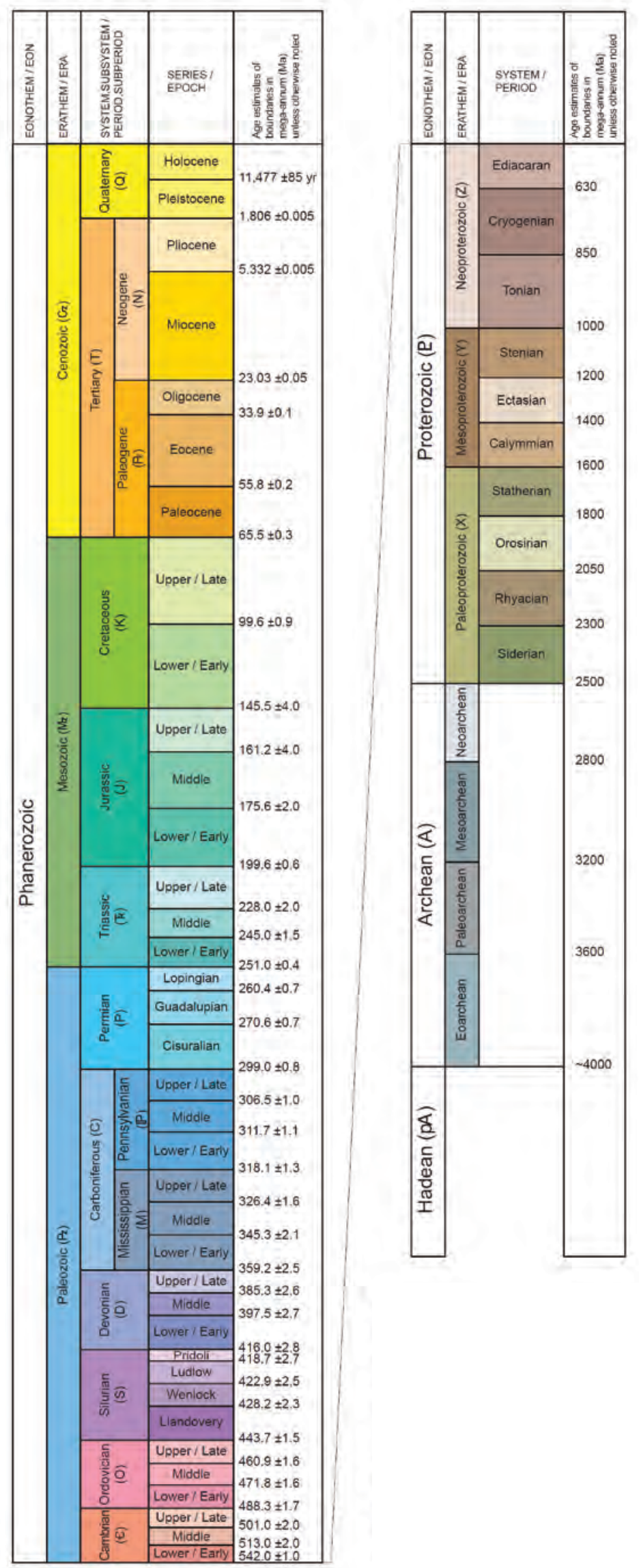

Figure 8. Divisions of geologic time (from U.S.

Geological Survey Geologic Names Committee, 2007). 


\section{Jornada del Muerto}

The Jornada del Muerto is a broad syncline that extends from the Caballo Mountains to the San Andres Mountains (fig. 7). The Jornada del Muerto contains a coal field in the Upper Cretaceous Crevasse Canyon Formation of the Mesaverde Group that extends from Socorro County (fig. 1), through Sierra County, and into western Doña Ana County (Bedinger and others, 1989). The Mesaverde Group is a nonmarine sequence of sandstone, shale, siltstone, and coal beds (Bedinger and others, 1989). The average annual precipitation in the area is about 10 in. (U.S. Climate Data, 2017).

\section{San Andres Mountains}

The San Andres Mountain range divides the Jornada del Muerto and the Tularosa Basin (fig. 7; Kottlowski, 1955), and structurally is made up of west-dipping fault blocks composed primarily of San Andres Limestone of Permian age (Seager, 1981). According to precipitation data from 1918 to 2002, average annual precipitation at the San Andres Wildlife Refuge, located in the southern San Andres Mountains, ranges from 7 to 25 in. depending on the elevation (Rawling, 2005).

\section{Organ Mountains and Doña Ana Mountains}

The Organ Mountains are a rugged and jagged mountain range located south of the San Andres Mountains and east of the city of Las Cruces, New Mexico (figs. 1 and 7; Glover, 1975). These mountains are composed of Tertiary volcanic intrusions, Tertiary-Quaternary gravels and alluvium, Paleozoic sedimentary rocks, and Precambrian granites. The dominant rock type is quartz-monzonite intrusions, especially on the western slopes (Glover, 1975). Average annual precipitation in the Organ Mountains ranges from 9 to 17 in. depending on the site within the mountains (Glover, 1975; Morino, 1996).

The Doña Ana Mountains transect Doña Ana County from the south-southeast to the north-northwest. The mountains, which reach the southwestern edge of the Jornada del Muerto (Seager and others, 1976), are westward-tilting. The bedrock ranges in age from Permian to Quaternary (Seager and others, 1976), and two-thirds of the bedrock is volcanic, including monzonites, andesites, obsidian, and ash flow tuff, and the remaining rocks are of sedimentary facies (Seager and others, 1976). Average annual rainfall in the Doña Ana Mountains is 8 to 9 in., with increased precipitation at higher elevations (Glover, 1975).

\section{Hueco Bolson and Tularosa Basin}

The Tularosa Basin is centrally located in the Tri-County planning area and is structurally and hydrologically connected to the Hueco Bolson to the south (fig. 7). The Tularosa Basin is a closed surface-water basin (Meinzer and Hare, 1915; Allmendinger and Titus, 1973), and its eastern and western boundaries include the San Andres Mountains, Sacramento Mountains, Sierra Blanca, and Hueco Mountains, all of which formed as a result of normal faulting. The sediments in the basin are Cenozoic in age, heterogeneous, and poorly consolidated, and overlie Mesozoic and Paleozoic sedimentary rocks. Deposits include fanglomerates, conglomerates, sandstones, caliche, shale, and gypsum (Allmendinger and Titus, 1973). Extensive areas of alkali flats and gypsum sands are present, including the gypsum sand dunes of White Sands National Monument (fig. 7; Meinzer and Hare, 1915). Streams, such as the Tularosa Creek and Three Rivers (fig. 1), flow into the basin from the topographic highs and deposit coarse-grained sediments close to the mountain front and finer grained sediments towards the center of the basin. These rivers are discussed further in the Surface Water section of this report. The average annual rainfall in the lowlands is approximately 10 in. (Meinzer and Hare, 1915).

\section{Sacramento Mountains}

The Sacramento Mountains are located in Otero County, extending from the Sierra Blanca to Otero Mesa (fig. 7; Pray, 1961). The mountains formed during the Tertiary period as a result of displacement along a major fault zone that trends north to south along its western edge (Pray, 1961). The lithological units range from Precambrian metamorphic/ granite facies to Cretaceous strata (Darton, 1921; Pray, 1961) to Tertiary igneous dikes and sills and Quaternary alluvium and terrace deposits (Pray, 1961). Average precipitation in the Sacramento Mountains ranges from 14 to $18 \mathrm{in} / \mathrm{yr}$ (BLM, 2005). The Sacramento River's headwaters are located in the Sacramento Mountains, and the river is an important feature for recharge to the Salt Basin.

\section{Otero Mesa}

Otero Mesa is an eastward-dipping, elevated plateau on the western edge of the Salt Basin (fig. 7; Huff and Chace, 2006). The Otero Mesa lies east of the Tularosa Basin and southwest of the Sacramento Mountains (fig. 7; Broadhead, 2003). Average precipitation on Otero Mesa is $11 \mathrm{in} / \mathrm{yr}$ (BLM, 2005). 


\section{Cornudas Mountains}

The Cornudas Mountains are igneous intrusions located in the southern part of the Tri-County planning area (fig. 7; Nutt and others, 1997). The mountains are underlain by Permian limestone and dolomitic sedimentary rocks, Cretaceous sandstone and shale, and late Eocene to early Oligocene alkaline intrusive rocks (Nutt and others, 1997). Average annual rainfall in the area is 13 in., delivered during July and August monsoon-season thunderstorms (Mayer, 1995).

\section{Salt Basin}

The Salt Basin is located in southern New Mexico and west Texas. In New Mexico, the basin covers 1,900 square miles $\left(\mathrm{mi}^{2}\right)$ and is bound by the Sacramento Mountains to the northwest, the Guadalupe Mountains to the east, Otero Mesa to the west, and the Cornudas Mountains to the southwest (fig. 7; Luna, 2005). An additional 4,000 $\mathrm{mi}^{2}$ of the basin are located in Texas (Bjorklund, 1957).

Average annual precipitation ranges from 10 in. in the central desert part of the Salt Basin to 25 in. in the higher mountains surrounding the basin (Livingston Associates, P.C., and John Shomaker and Associates, Inc., 2002). Mountainfront recharge flows in the subsurface along the Otero Break and discharges into the Salt Basin. Snowmelt in higher elevations creates prolonged groundwater recharge that recharges base flow in streams and springs in the basin. Lower elevations receive heavy rains and thunderstorms during summer monsoons (Finch, 2002).

\section{Guadalupe Mountains}

The Guadalupe Mountains are located in eastern Otero County, but also reach into west Texas at their southernmost extent (fig. 7; Hayes, 1964). The Guadalupe Mountains are composed of Precambrian granites, metavolcanics (metamorphosed volcanic rocks), metasedimentary (metamorphosed sedimentary) rocks (Hayes, 1964), Permian strata (Kues, 2006), igneous Tertiary dikes, and Quaternary alluvium (Hayes, 1964). Permian deposits include one of the most diverse ancient marine reef systems that has ever been found, the Capitan Reef (Kues, 2006). The average annual precipitation in the Guadalupe Mountains is a maximum of 18 in. as rain and 5 in. as snow (Western Regional Climate Center, 2017).

\section{Surficial and Structural Geology}

The surface geology of the Tri-County planning area includes Precambrian (Proterozoic) metamorphic and granitic plutonic rocks; Permian sandstones, limestones, and shales; and Quaternary alluvium (fig. 4). In areas such as the Caballo and San Andres Mountains, Precambrian plutonic rocks, metavolcanics, and quartzites are exposed at the surface (NMBGMR, 2003). Paleozoic rocks are also exposed at the surface in uplifted areas. These rocks include Cambrian sandstones, Ordovician and Silurian limestones, Devonian shales, Mississippian limestones, and Pennsylvanian limestones, shales, and sandstones (NMBGMR, 2003). In the eastern part of the Tri-County planning area, Permian rocks in the form of limestones, shales, and sandstones are found at the surface (NMBGMR, 2003). Mesozoic rocks in the Tri-County planning area consist primarily of Cretaceous deposits (Bedinger and others, 1989) and can be found in the Sacramento Mountains and the Jornada del Muerto (NMBGMR, 2003). Tertiary rocks are present in the TriCounty planning area in the form of the Lower Santa Fe Group, volcanic rocks such as rhyolite and tuff, and scattered intrusive igneous rocks (NMBGMR, 2003). Surficial deposits in the basins and low-lying areas are predominantly younger, unconsolidated Quaternary deposits that include the Upper Santa Fe Group, alluvium, piedmont alluvium, eolian deposits, and some volcanic deposits (NMBGMR, 2003). 
Structurally, the Tri-County planning area consists of a series of north-south-trending structural basins and uplifts separated by high-angle $\left(70\right.$ to $\left.90^{\circ}\right)$ normal or reverse faults (Bedinger and others, 1989; Hawley and Kennedy, 2004; Ritchie, 2011). The geologic cross sections show the complex faulting in the Tri-County planning area (figs. 9 and 10A-D). These basin-bounding high-angle faults and fault zones have relative displacements of as much as several thousand feet that juxtapose Cenozoic alluvial deposits and Cretaceous sedimentary rocks in the down-faulted blocks with older Cretaceous, Permian, Pennsylvanian, and older Paleozoic sedimentary rocks, and Precambrian igneous rocks in the up-faulted blocks (Bedinger and others, 1989). The current structural setting of the Tri-County planning area is the result of the ongoing Basin and Range Province extension that began about 25 to 30 million years ago (Ma) in the Oligocene and produced the Rio Grande rift (Hawley and Kennedy, 2004). These recent Basin and Range extensional features are often superimposed on older structures associated with midTertiary volcanism and Late Cretaceous to Early Cenozoic compressional tectonics of the Laramide orogeny (Bedinger and others, 1989; Hawley and Kennedy, 2004; Ritchie, 2011). However, the Jornada del Muerto has little to no faulting even though it is located in an extensionally dominated terrane near the Rio Grande rift (Lozinsky, 1987). Evidence of the lack of faulting includes the relatively thin (less than $400 \mathrm{ft}$ ) Santa $\mathrm{Fe}$ Group deposit of Quaternary-Tertiary age (Lozinsky, 1987). Because of variable uplifting in the San Andres Mountains, Precambrian through Tertiary sedimentary rocks are well exposed at the surface. Precambrian rocks include granites and metamorphic schists. Faulting has exposed gypsum evaporite units of the Permian Yeso Formation, allowing rain to dissolve the soluble salt deposits and transport them through surface water and groundwater towards the Tularosa Basin (Allmendinger and Titus, 1973), potentially affecting the water quality in the basin. On Otero Mesa, gently folded Permian strata are seen at the surface of the mesa; however, the subsurface is structurally complex. The multiple folds and faults in the subsurface are likely the result of reactivation of Ancestral Rocky Mountain faults (Black, 1976; Broadhead, 2003). The Otero Break is a prominent zone of fracturing that extends southeast from the Sacramento Mountains (fig. 7; Mayer, 1995; Mayer and Sharp, 1998). The Otero Break will be discussed further in the Hydrologic Assessment section of this report. The Salt Basin, which is defined structurally by north-south-trending, high-angle normal faults along the eastern and western margins, also exhibits horst-graben-horst morphology in its cross section (Finch, 2002). The western edge of the Sacramento Mountains is characterized by steep escarpments, while the eastern side has a gentle slope (Pray, 1961). This mountain range exhibits structural features such as anticlines, synclines, and thrust faults that were generated during the Pennsylvanian and Permian periods (Pray, 1961). The Guadalupe Mountains have gentle slopes on the east side and steep cliffs on their western flank. The mountains were uplifted as a result of north to northwest normal faulting that took place in the late Cenozoic Era (Hayes, 1964). Paleozoic thrust faulting and folding (King, 1948; Hayes, 1964), Mesozoic faulting (King, 1948), and early Cenozoic folding (King, 1948; Hayes, 1964) are evident within the rock units.

Precambrian rocks are exposed in uplifts of the San Andres, Caballo, Organ, and Hueco Mountains and the Fra Cristobal Range (fig. 7; Bedinger and others, 1989). Paleozoic rocks are exposed in most mountain uplifts and on the gently eastward-sloping surface of the Otero Mesa. Based on outcrop and subsurface sections, Paleozoic rocks in the Tri-County planning area range in thickness from approximately 3,000 to $8,000 \mathrm{ft}$ (Kottlowski, 1965). Cretaceous rocks are primarily present in the western part of Doña Ana County and central part of Sierra County, with large parts of Upper Cretaceous rocks removed from the region by erosion during the Cenozoic era (Kottlowski, 1965). The thickness of Cenozoic sedimentary alluvial deposits in the structural basins ranges from tens-of-ft on plateau surfaces to several thousand feet in valley interiors (Bedinger and others, 1989; Hawley and Kennedy, 2004; Ritchie, 2011). These sedimentary deposits are locally interbedded with and capped by basaltic to andesitic lava flows and pyroclastic deposits (Hawley and Kennedy, 2004; Sweetkind, 2017).

\section{Geologic History}

The Tri-County planning area has undergone multiple tectonic events and different depositional environments. This subsection describes these events and deposits which are no longer expressed on the surface. In general, lower Paleozoic (Cambrian through Mississippian) rocks in the study area were deposited on a stable shallow-marine shelf and thin northward because of syndepositional thinning and erosion to the north (King and Harder, 1985; Cather and Harrison, 2002; Raatz, 2002). The Late Mississippian to Early Pennsylvanian marked a shift to a more active tectonic regime in the study area that persisted throughout most of the remainder of the Paleozoic, and was characterized by the development of the Ancestral Rocky Mountains because of collision of North America (Laurentia) with South America-Africa (Gondwana) (Kluth and Coney, 1981; Kluth, 1986; Raatz, 2002; Poole and others, 2005). In the study area, structural features associated with the Ancestral Rocky Mountains include the Pedernal uplift (near the present-day Sacramento Mountains in eastern Otero County) and Orogrande Basin (near the present-day Tularosa Basin in western Otero County and eastern Sierra and Doña Ana Counties) (Cather and Harrison, 2002; Raatz, 2002). The Orogrande Basin was surrounded by a narrow, high-relief shelf on the east and a broad, low-relief shelf on the west (Raatz, 2002; Mack and others, 2013). 

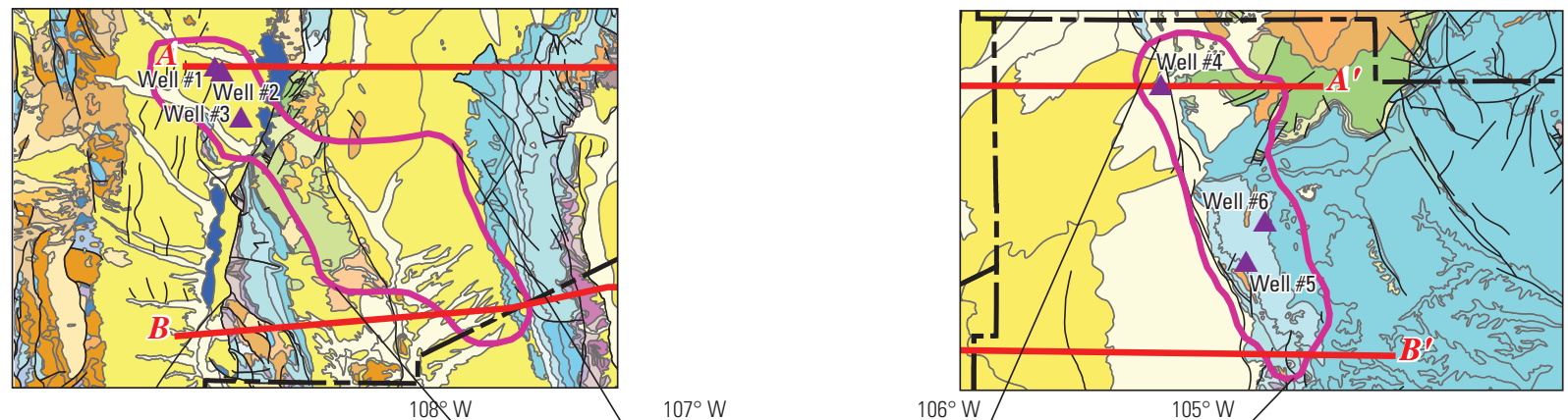

\section{EXPLANATION}

$A-A^{\prime}$ Geologic cross section

- Areas of potential oil and gas occurrence

- NMOCD well log locations

for hydrostratigraphic

columns described in table 1

Well \#1 API 30-051-20009

Well \#2 API 30-051-00007

Well \#3 API 30-051-20008

Well \#4 API 30-035-20015

Well \#5 API 30-035-20011

Well \#6 API 30-035-20025

Well \#7 API 30-035-20027

Well \#8 API 30-035-20028

Well \#9 API 30-035-00012

\section{Geologic units}

Quaternary
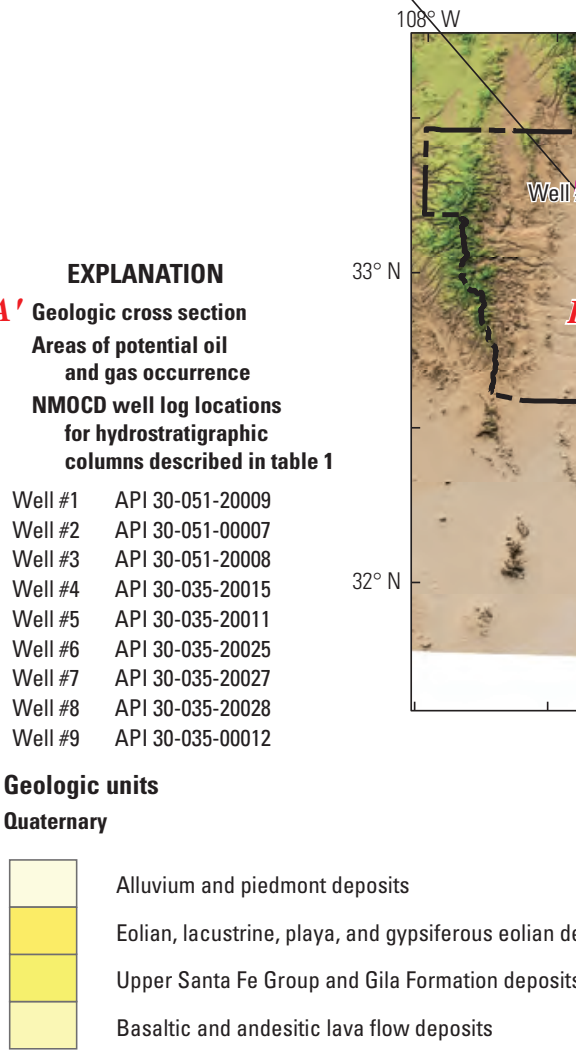

Alluvium and piedmont deposits

Eolian, lacustrine, playa, and gypsiferous eolian deposits

Upper Santa Fe Group and Gila Formation deposits

Basaltic and andesitic lava flow deposits

Tertiary

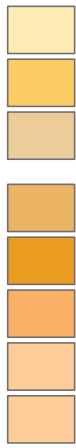

Lower Santa Fe Group deposits

Late Tertiary basaltic and andesitic lava flow deposits

Upper to middle Tertiary silicic to intermediate volcanic rocks, rhyolitic lavas, and tuff deposits

Middle Tertiary volcanic rocks and volcaniclastic sedimentary deposits

Tertiary to Cretaceous basaltic andesites, rhyolitic lavas and tuffs, volcanic, andesitic, dacitic, and pyroclastic breccia deposits

Intermediate to silicic intrusive rock deposits

Early Tertiary sedimentary rocks

Cretaceous

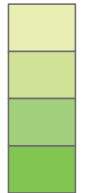

Upper, lower, and undivided Cretaceous rocks

Mesa Verde Group

Mancos Shale

Dakota Sandstone

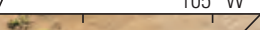

Paleozoic rocks, undivided

Permian rocks, undivided

Permian rocks, Artesia Group and Queen and Grayburg Formations

Permian rocks, San Andres Limestone and Yeso Formation

Permian rocks, Hueco, Abo, and Bursum Formations

Pennsylvanian rocks, undivided

Pennsylvanian rocks, Madera Group, Panther Seep Formation, and Lead Camp Limestone

Mississippian, Devonian, Silurian, and Cambrian rocks, undivided

Mississippian through Cambrian rocks, undivided

\section{Proterozoic}

Mesoproterozoic granitic rocks

Paleoproterozoic granitic rocks

Paleoproterozoic mafic, rhyolite, and felsic volcanics and volcanic schist rocks

Paleoproterozoic quartzite rocks

Paleoproterozoic metasedimentary rocks

Figure 9. Locations of geologic cross sections, areas of potential oil and gas occurrence, and wells with logs (New Mexico Oil Conservation Division [NMOCD], 2016b). See table 1 for more information from specific well logs. 


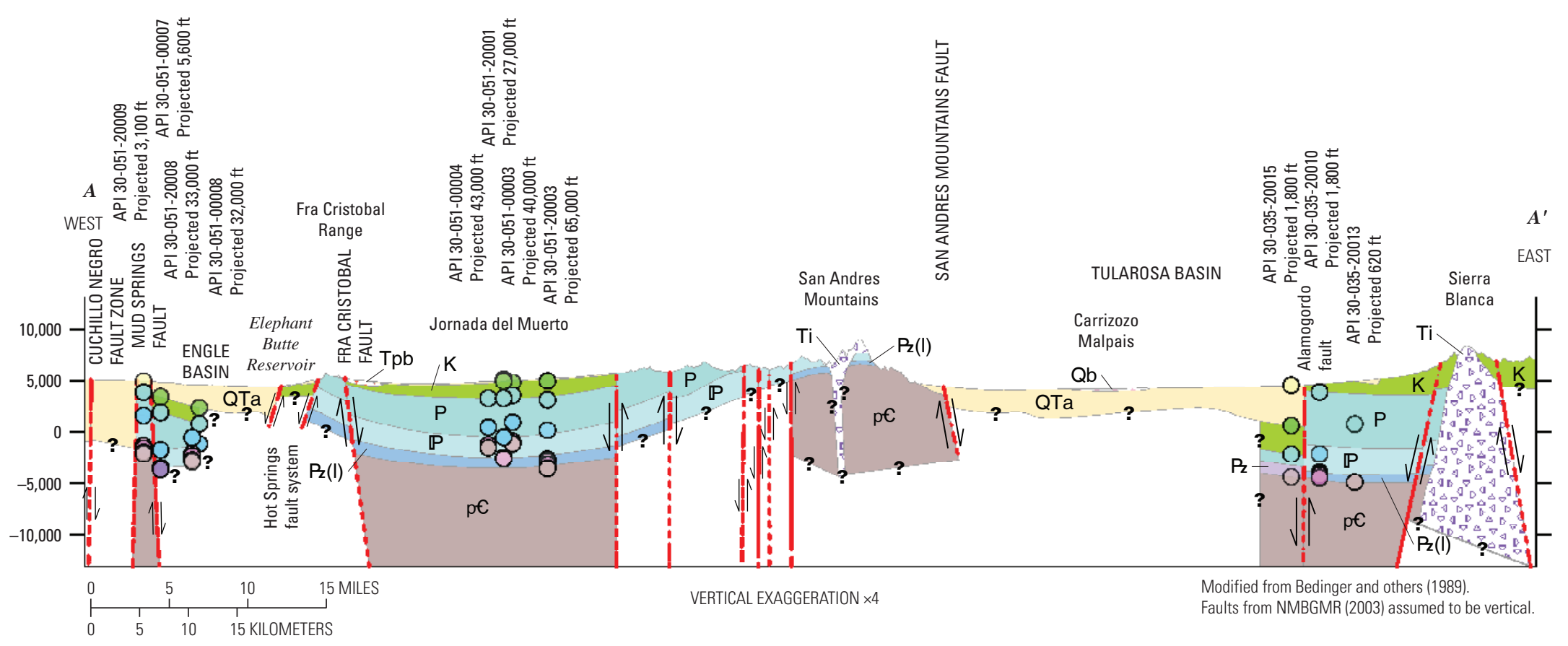

EXPLANATION

Stratigraphy

Unit - Description

Unkown

Qb Quaternary basaltic to andesitic lava flows

QTa Cenozoic basin fill; alluvium

Tpb Tertiary basaltic to andesitic lava flows

$F_{0}^{\circ} \mathrm{Ti} \quad$ Tertiary intrusive rocks

K Cretaceous, undivided

$P \quad$ Permian, undivided

$\mathbb{P}$ Pennsylvanian, undivided

$\mathrm{Pz}_{\mathbf{z}}(\mathrm{I})$ Paleozoic (lower), undivided

$\mathrm{Pz} \quad$ Paleozoic, undivided

pC Precambrian, undivided

$\leftrightharpoons$ - Faults-arrows on either side of the faults

indicate the direction of relative

displacement across each fault

Formation names use standard geologic nomenclature.

Question marks indicate lithology uncertain.

Stratigraphy from well logs

Unit - Description

QTa Cenozoic basin fill; alluvium

O K Cretaceous, undivide

O $P_{\mathbf{Z}}(\mathrm{u}), \mathrm{P}$ Permian, undivided

$\bigcirc \quad P_{2}(u) \quad$ Permian / Pennsylvanian carbonate rocks

$\bigcirc \quad B_{2}(u), \mathbb{P}$ Pennsylvanian, undivided

P $P_{2}(I), M \quad$ Mississippian, undivided

O $P(I), D$ Devonian, undivided

O $P_{\mathbf{Z}}(I), S$ Silurian

O $\quad \mathrm{P}_{2}(\mathrm{I}), \mathrm{O}$ Montoya

$\mathrm{B}(\mathrm{l}), \mathrm{O}$ El Paso

$\bigcirc \quad P(I)$, O€ Bliss

$\bigcirc$ pe Precambrian

Figure 10. Geologic cross sections in the Tri-County planning area, New Mexico. $A, A-A^{\prime} . B, B-B^{\prime} . C, C-C^{\prime}$. D, $D-D^{\prime}$. Cross section locations are shown in figure 9. 


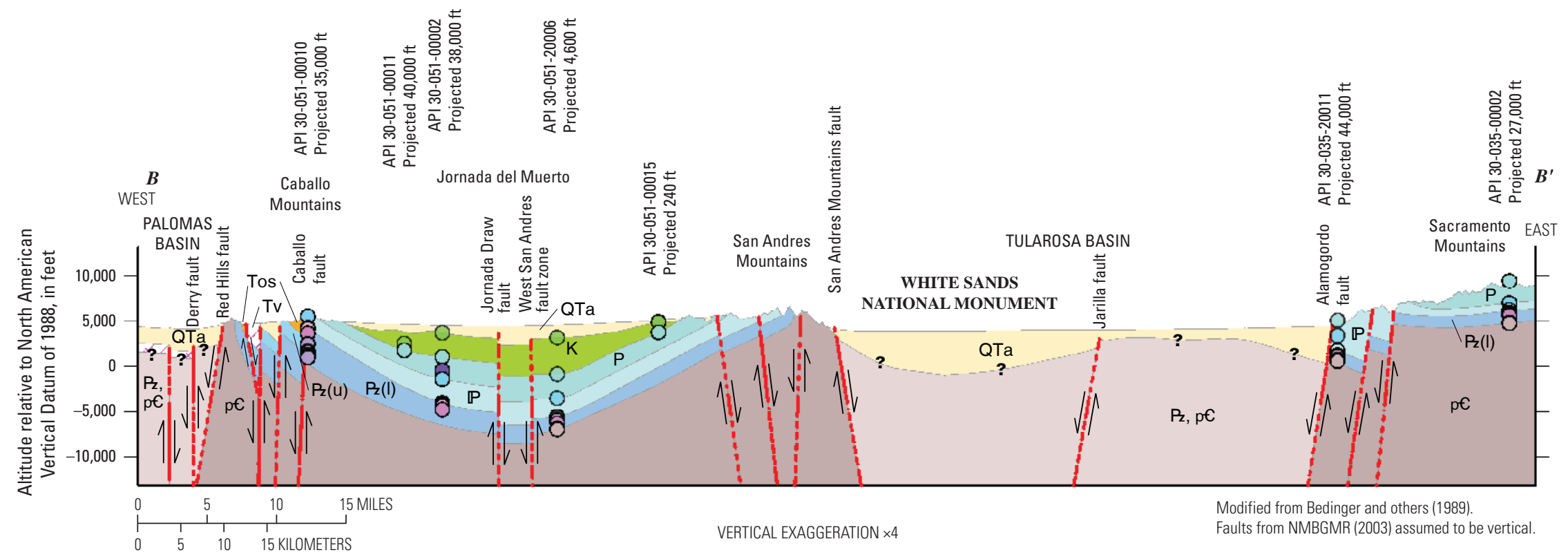

\section{EXPLANATION}

Stratigraphy

Unit - Description

QTa Cenozoic basin fill; alluvium

Tos Tertiary basaltic to andesitic lava flows

¿X TV Tertiary intrusive rocks

K Cretaceous, undivided

$P_{z}(u)$ Paleozoic (upper), undivided

P Permian, undivided

P Pennsylvanian, undivided

$\mathrm{B}$ (I) Paleozoic (lower), undivided

$\mathrm{Pz}$, p€ Paleozoic, undivided

p€ Precambrian, undivided

$=$ - Faults-arrows on either side of the faults

indicate the direction of relative displacement across each fault
Stratigraphy from well logs

\section{Unit - Description}

Ti? Tertiary (uncertain) intrusives

O K Cretaceous, undivided

$\mathrm{P}(\mathrm{u}), \mathrm{P}$ Permian, undivided

$\bigcirc \quad P_{2}(\mathrm{u}), \mathbb{P}$ Pennsylvanian, undivided

O $\mathrm{P}_{\mathbf{2}}(\mathrm{l}), \mathrm{M}$ Mississippian, undivided

P $P_{2}(I), D$ Devonian, undivided

$\bigcirc \quad P_{2}(I), S$ Silurian

$\mathrm{P}(\mathrm{I})$, SO Montoya and Fusselman, undifferentiated

O $\quad P_{2}(I), O \quad$ Montoya

O $P_{2}(I), O \quad$ El Paso

O $\mathrm{P}_{2}(\mathrm{I}), \mathrm{O}$, Bliss

$\bigcirc$ pe Precambrian

Formation names use standard geologic nomenclature. Question marks indic ate lithology uncertain. 


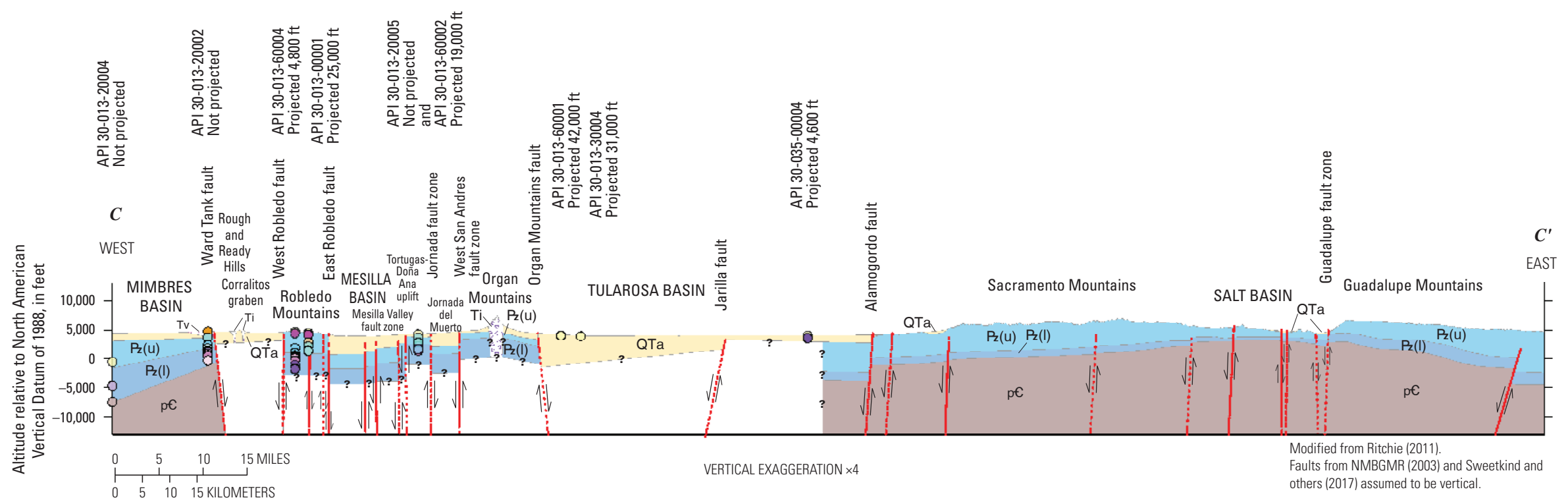

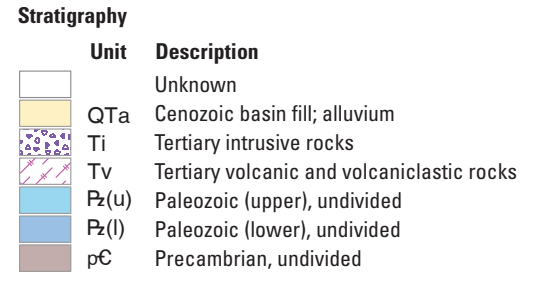

$=$ - Faults-arrows on either side of the faults indicate the direction of relative displacement across each fault

\section{EXPLANATION}

\section{Stratigraphy from well logs}

Unit Description

QTa Cenozoic basin fill; alluvium

Ti? Tertiary (uncertain) intrusives

Tv Tertiary volcanic and volcaniclastic rocks

Tvs Rubio Peak Formation (Palm Park)

Tps Lower Tertiary (to Cretaceous [uncertain] Lobo Formation (Love Ranch)

Pz Paleozoic, undivided

$\mathrm{Pz}(\mathrm{u}), \mathrm{P}$ Permian, undivided

Pz, Ph or M? Sill, Hueco, or Mississippian (uncertain)

\begin{tabular}{|c|c|c|}
\hline & Unit & Description \\
\hline o & $P_{2}(u), \mathbb{P}$ & Pennsylvanian, undivided \\
\hline & $\mathrm{P}_{2}(\mathrm{u}) ; \mathbb{P}, \mathrm{M}$, or $\mathrm{D}$ ? & $\begin{array}{l}\text { Pennsylvanian, Mississippian, or } \\
\text { Devonian (uncertain) }\end{array}$ \\
\hline & $P_{2}(I), M$ & Mississippian, undivided \\
\hline & $P_{2}(I), D$ & Percha \\
\hline & $P_{2}(I), S$ & Fusselman \\
\hline & $P_{2}(I), O$ & Montoya \\
\hline & $P_{2}(I), O$ & El Paso \\
\hline & $P_{2}(I), O €$ & Bliss \\
\hline & $p \in$ & Precambrian \\
\hline
\end{tabular}

Formation names use standard geologic nomenclature.

Question marks indicate lithology uncertain.

Figure 10. Geologic cross sections in the Tri-County planning area, New Mexico. A, $A-A^{\prime}$. B, B-B'. C, C- $C^{\prime}$. D, D- $D^{\prime}$. Cross section locations are shown in figure 9.-Continued 


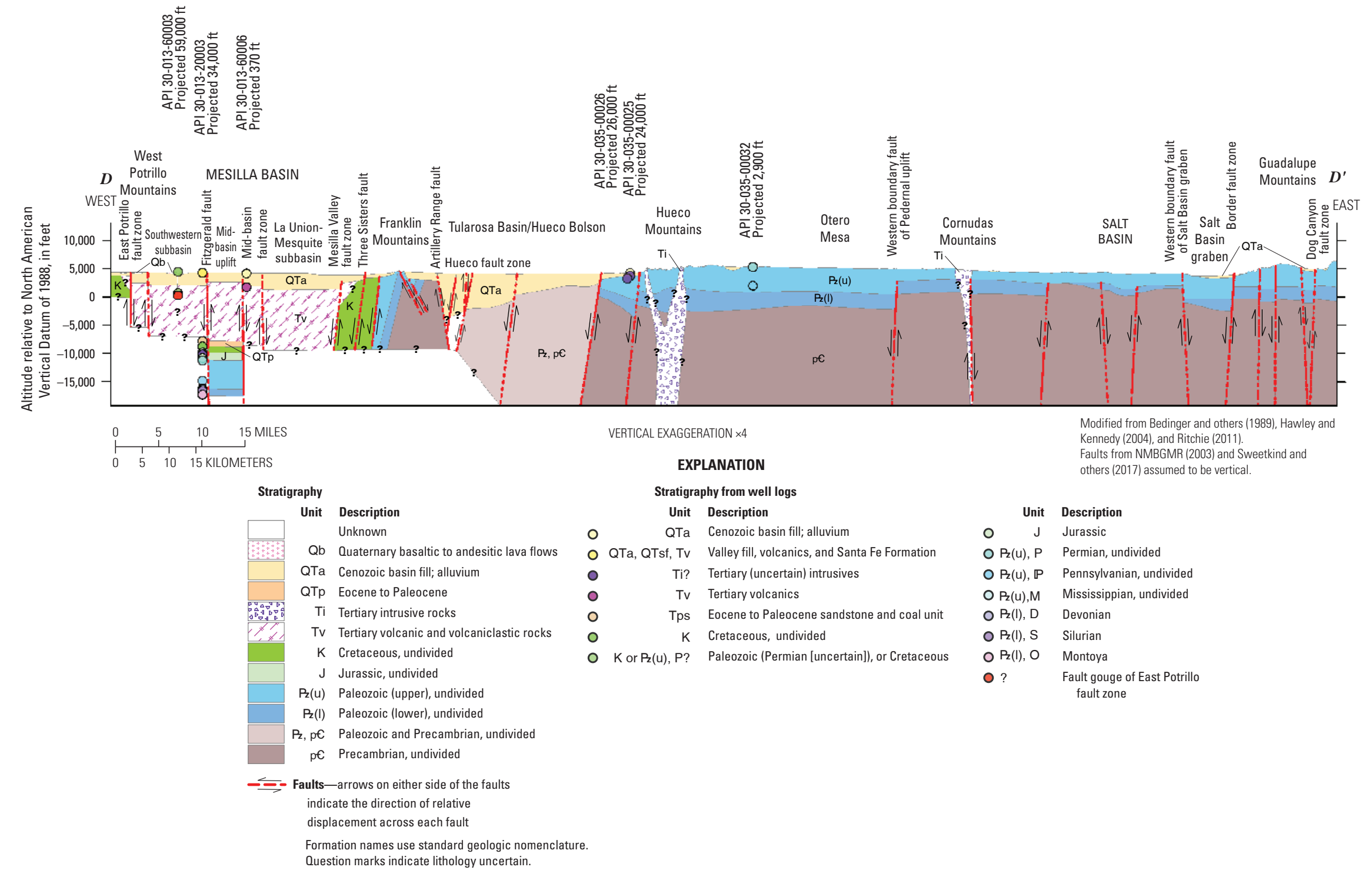


In general, Pennsylvanian rocks in the study area gradually thickened from west to east along the shelf towards a maximum thickness in the Orogrande Basin (a paleofeature), and rapidly thinned east from the Orogrande Basin along the shelf towards an eroded edge along the Pedernal uplift (Kottlowski, 1965; Foster, 1978; King and Harder, 1985). Active uplift and subsidence along the Ancestral Rocky Mountain structural features persisted into the early Permian with continued infilling of the Orogrande Basin (King and Harder, 1985; Mack and others, 1998; Raatz, 2002). In general, early Permian strata of the Hueco and Abo Formations in the study area rapidly thicken westward away from the Pedernal uplift towards the Orogrande Basin and gradually thin westward away from the Orogrande Basin, with the Hueco thickening southward and the Abo thinning southward (Kottlowski, 1965; Foster, 1978; King and Harder, 1985; Raatz, 2002). Rocks deposited during the Pennsylvanian and early Permian are not present or are relatively thin in the eastern and southeastern parts of Otero County because of erosion associated with the Pedernal uplift (Kottlowski, 1965; King and Harder, 1985; Broadhead, 2003; Ritchie, 2011; Newton and others, 2012). The remainder of the Permian marked a return to a stable tectonic regime, with the Pedernal uplift greatly reduced and the Orogrande Basin almost filled, forming a stable shallow-marine shelf on which the Permian units were deposited (Mack and others, 1998; Raatz, 2002; Ritchie, 2011). These later Permian strata of the Yeso, Glorieta, and San Andres Formations thicken generally southwestward in the study area, terminating at a Mesozoic eroded edge trending from southwest Sierra County to north of Las Cruces, New Mexico, to west of the Cornudas Mountains (Kottlowski, 1965, 1969; Raatz, 2002).

Mesozoic rocks are largely not present in the study area, having been removed by erosion during the Jurassic and Early Cretaceous (Kottlowski, 1965; Foster, 1978; Raatz, 2002). Scattered exposures of Triassic rocks are found in the far northern part of Otero County (Foster, 1978; NMBGMR, 2003). A 670-ft marine Jurassic section was reported in well API number 30-013-20003 (fig. 10D, cross section D-D'), but these are the only reported Jurassic rocks in the study area (Thompson and Bieberman, 1975; Foster, 1978; King and Harder, 1985). Lower Cretaceous rocks in the study area were deposited in the Chihuahua trough, a northwest-trending, extensional basin that formed southwest of the study area and was the site of a marine sea during the Early Cretaceous, with the northern limit of deposition trending from south of Caballo Reservoir to the southern San Andres Mountains to north of the Cornudas Mountains (Kottlowski, 1965; Mack and others, 1998; Raatz, 2002). In the study area, Lower Cretaceous rocks thicken to the southwest and have been removed by erosion in the southwest part of Sierra and Otero Counties and central and eastern Doña Ana County (Kottlowski, 1965).
Upper Cretaceous rocks in the study area were deposited in the southwestern margin of the ancient Western Interior Seaway, with the southern limit of deposition trending from near Deming, New Mexico, to El Paso, Texas (Kottlowski, 1965; Mack and others, 1998; Raatz, 2002). In general, Upper Cretaceous rocks thicken to the north in the study area with a maximum thickness near the Caballo Mountains and Fra Cristobal Range in central Sierra County, and have been removed by erosion during the Cenozoic over western Sierra County, eastern Sierra and Doña Ana Counties, and most of Otero County (Kottlowski, 1965; Raatz, 2002).

The Laramide orogeny during the Late Cretaceous through the Eocene resulted in the northwest-trending Rio Grande uplift and surrounding Love Ranch and Potrillo Basins to the north in central New Mexico and to the south in central New Mexico, respectively (Mack and others, 1998; Raatz, 2002). These basins were subsequently infilled with the deposits of the McRae and Love Ranch Formations (Mack and others, 1998; Raatz, 2002). The Eocene to the Miocene was marked by volcanism that produced the Palm Park Formation (named for exposures in the Caballo Mountains) and its correlations in the Doña Ana and Organ Mountains, the Sierra Blanca volcanics, and numerous intrusions in the San Andres, Sacramento, Hueco, and Cornudas Mountains (Foster, 1978; King and Harder, 1985; Mack and others, 1998; Nutt and O'Neill, 1998; Raatz, 2002; Broadhead, 2003; Newton and others, 2012).

The initial stage of crustal extension associated with the Rio Grande rift began in the Oligocene and culminated in the early Miocene with the deposition of the Haynor Ranch and Rincon Valley Formations, but with little associated volcanism (Mack and others, 1998; Raatz 2002; Hawley and Kennedy, 2004). The second stage of extension began in the late Miocene (approximately $10 \mathrm{Ma}$ ) and continues to the present day, and produced the current configuration of uplifts and basins bounded by high-angle normal faults (Mack and others, 1998; Raatz, 2002). The Pliocene to early Pleistocene sedimentary rocks of the Palomas and Camp Rice Formations were deposited by the ancestral Rio Grande in the Palomas and Mesilla Basins, the western and eastern (between the Doña Ana and San Andres Mountains) parts of the Jornada del Muerto, and the southern part of the Tularosa Basin during this second stage of extension (Mack and others, 1997, 1998; Raatz, 2002). These Neogene to early Pleistocene strata of the Haynor Ranch, Rincon Valley, Palomas, and Camp Rice Formations are included in the Santa Fe Group (Sweetkind, 2017). In addition, the second stage of Rio Grande rift extension was characterized by basalt volcanism as seen in the West Potrillo Mountains (southwestern Doña Ana County), Jornada basalt field (northern Sierra County), and Carrizozo Malpais (northwestern Otero County) (Hoffer and Corbitt, 1991; Mack and others, 1998; Dunbar, 1999; Raatz, 2002). 
About $0.78 \mathrm{Ma}$, the ancestral Rio Grande and its tributaries began to incise the Santa Fe Group sediments and backfill the basins (Mack and others, 1997, 1998, 2006; Sweetkind, 2017). During the Pleistocene to early Holocene, lakes formed in the Jornada del Muerto and the Tularosa and Salt Basins and left behind evaporite deposits (Neal and others, 1983; Hawley, 1993; O’Neill, 1998; Gile, 2002; Raatz, 2002; Newton and Allen, 2014). One of the largest lakes in the study area, perennial Lake Otero, filled the west-central part of the Tularosa Basin (Raatz 2002; Newton and Allen, 2014). As the lake dried and constricted, dissolved salts derived primarily from the Yeso Formation were deposited as evaporates, predominantly gypsum, which were subsequently transported eastward by the prevailing wind direction to form the dune field at White Sands National Monument (Raatz, 2002; Newton and Allen, 2014). The Salt Basin and parts of the Jornada del Muerto and Tularosa Basins not containing ancestral Rio Grande deposits are filled with Tertiary to Quaternary alluvial, fluvial, eolian, lacustrine, and playa deposits (O’Neill, 1998; NMBGMR, 2003; Mamer and others, 2014; Newton and Allen, 2014; Newton and others, 2015).

\section{Geologic Cross Sections}

Four east-west-oriented geologic cross sections spanning the overall extent of the Tri-County planning area show the structure and surface and subsurface geology of the area from the Proterozoic Eon through the Quaternary period (figs. 9-10; note a vertical exaggeration of four times in figure 10). Landsurface elevation as depicted on the cross sections is defined by using a 1 arc-second (approximately 98-ft horizontal resolution) digital elevation model obtained from the USGS 3D Elevation Program (USGS, 2013a-f, 2016a-b). Elevations are relative to the North American Vertical Datum of 1988.

The cross sections show the overall subsurface geology including depth from surface and thickness of the units of the Tri-County planning area, which aid in understanding water resources and oil and gas potential in relation to subsurface deposits. The location and elevation of surface and subsurface geologic unit descriptions from oil and gas exploratory well logs are shown as colored circles. In some cases, the exploratory well did not coincide with the line of cross section at the land surface, and these wells were projected to the line of cross section along the shortest straight-line distance from the well's actual location, taking into account any dip associated with the geologic units. The maximum projected distance was $65,000 \mathrm{ft}$ for a well on cross section $A-A^{\prime}$, with an average projected distance for all cross sections of 24,000 ft. Location information was obtained from the NMOCD (2016b) and the NMBGMR (A. Trivitt-Kracke, NMBGMR, written commun., June 10, 2016). Location information obtained from the NMOCD was in an ArcGIS shapefile format, using the UTM coordinate system zone 13 north, NAD 83, in units of meters. Location information obtained from the NMBGMR was in a tabular format, using latitude and longitude geographic coordinates in decimal degrees, with an undefined horizontal datum. The horizontal datum for the NMBGMR location information was assumed to be NAD 83, and locations were converted to a projected coordinate system, UTM zone 13 north, in units of meters to be consistent with the NMOCD location information.

Oil and gas exploratory wells are labeled on each cross section with each well's API number, whether or not the well was projected, and the distance the well was projected if applicable. Location coordinates, depth to geologic unit picks from exploratory wells made by petroleum geologists, and data sources for oil and gas exploratory wells displayed on cross sections $A-A^{\prime}$ through $D-D$ ' are provided in the associated data release (Blake and others, 2017). The process used to determine the depth to geologic unit picks is discussed in the Methods section of this report. Table 1 provides information about the age, geologic unit, depth, unit description, and hydrogeologic characteristics of API wells used in the cross sections.

Each cross section illustrates the structural features and resultant lateral and vertical extents of the geologic units that typify the Tri-County planning area of southern New Mexico. 
Table 1. Summary of hydrostratigraphic nomenclature and description of rock units in areas of interest, Jornada del Muerto, Tularosa Basin, and Otero Mesa, New Mexico.

[Locations of geologic cross sections and wells shown in figure 9; ft, foot; API, American Petroleum Institute. gal/min, gallon per minute; --, no data; (gal/d)/ft, gallons per day per foot; , approximately]

Wells located on cross section $A-A^{\prime}$

Well log information from the Jornada del Muerto high oil and gas occurrence potential area Well API 30-051-20009 Well \#1

\begin{tabular}{|c|c|c|c|c|c|c|c|}
\hline $\begin{array}{l}\text { Eonothem/ } \\
\text { eon }\end{array}$ & $\begin{array}{l}\text { Erathem/ } \\
\text { era }\end{array}$ & $\begin{array}{c}\text { System/ } \\
\text { subsystem/ } \\
\text { period/subperiod }\end{array}$ & $\begin{array}{l}\text { Geologic } \\
\text { unit }\end{array}$ & Abbreviation & $\begin{array}{l}\text { Depth from } \\
\text { surface } \\
\text { (ft) }\end{array}$ & $\begin{array}{c}\text { Unit } \\
\text { description }\end{array}$ & Hydrogeologic characteristics \\
\hline \multirow{5}{*}{ 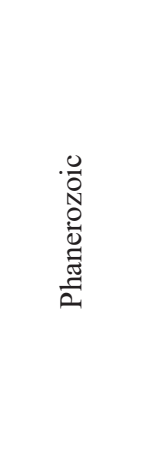 } & $\begin{array}{l}0 \\
0 \\
0 \\
0 \\
0 \\
0\end{array}$ & Quaternary & Alluvium & Qal & $0-3,328$ & $\begin{array}{l}\text { Sand, gravel, and } \\
\text { redbeds }\end{array}$ & Permeable; irrigation wells yield $1,000 \mathrm{gal} / \mathrm{min}{ }^{1}$ \\
\hline & \multirow{4}{*}{ 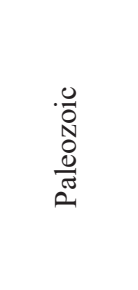 } & Pennsylvanian & Undifferentiated & $\mathrm{P}$ & $3,328-6,286$ & Limestone and shale & Yield small amounts of water. ${ }^{2}$ \\
\hline & & \multirow[t]{2}{*}{ Ordovician } & Montoya Group & $\mathrm{O}$ & $6,286-6,514$ & Dolomite & Unknown. \\
\hline & & & El Paso Group & $\mathrm{O}$ & $6,514-6,925$ & $\begin{array}{l}\text { Sandstone, dolomite, } \\
\text { and limestone }\end{array}$ & Unknown. \\
\hline & & $\begin{array}{l}\text { Cambro- } \\
\text { Ordovician }\end{array}$ & Bliss Sandstone & $\mathrm{OC}$ & $6,925-7,069$ & $\begin{array}{l}\text { Sandstone, limestone, } \\
\text { and dolomite }\end{array}$ & Relatively impermeable. ${ }^{1}$ Porosity is 3.4 to 7.6 percent. ${ }^{3}$ \\
\hline $\begin{array}{l}0 \\
0 \\
0 \\
0 \\
0 \\
0 \\
0 \\
0 \\
0\end{array}$ & & Precambrian & Granite & $\mathrm{pC}$ & $7,069-7,230$ & Crystalline rock & Relatively impermeable. ${ }^{1}$ \\
\hline
\end{tabular}


Table 1. Summary of hydrostratigraphic nomenclature and description of rock units in areas of interest, Jornada del Muerto, Tularosa Basin, and Otero Mesa, New Mexico.Continued

[Locations of geologic cross sections and wells shown in figure 9; ft, foot; API, American Petroleum Institute. gal/min, gallon per minute; --, no data; (gal/d)/ft, gallons per day per foot; , approximately]

Wells located on cross section $A-A^{\prime}-$ Continued

Well log information from the Jornada del Muerto high oil and gas occurrence potential area-Continued

Well API 30-051-00007 Well \#2

\begin{tabular}{|c|c|c|c|c|c|c|c|}
\hline $\begin{array}{l}\text { Eonothem/ } \\
\text { eon }\end{array}$ & $\begin{array}{l}\text { Erathem/ } \\
\text { era }\end{array}$ & $\begin{array}{c}\text { System/ } \\
\text { subsystem/ } \\
\text { period/subperiod }\end{array}$ & $\begin{array}{l}\text { Geologic } \\
\text { unit }\end{array}$ & Abbreviation & $\begin{array}{l}\text { Depth from } \\
\text { surface } \\
\text { (ft) }\end{array}$ & $\begin{array}{c}\text { Unit } \\
\text { description }\end{array}$ & Hydrogeologic characteristics \\
\hline \multirow{11}{*}{ 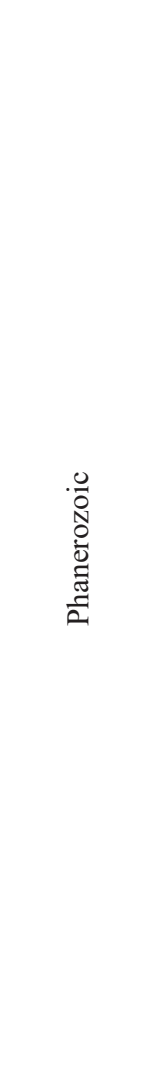 } & \multirow{3}{*}{ 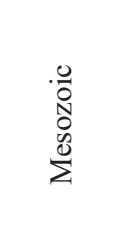 } & $\begin{array}{l}\text { Tertiary- } \\
\text { Cretaceous }\end{array}$ & $\begin{array}{l}\text { McRae } \\
\text { Formation }\end{array}$ & $\mathrm{Kmc}$ & $1,450-1,539$ & Coal-bearing sandstone and shale & Unknown. \\
\hline & & \multirow[t]{2}{*}{ Cretaceous } & $\begin{array}{l}\text { Mesaverde } \\
\text { Formation }\end{array}$ & $\mathrm{Kmv}$ & $1,539-1,590$ & $\begin{array}{l}\text { Lenticular sandstone reservoir beds, } \\
\text { coal shows }\end{array}$ & $\begin{array}{l}\text { Springs and groundwater wells can yield } \\
2-4 \mathrm{gal} / \mathrm{min} \text { (impotable). }{ }^{2}\end{array}$ \\
\hline & & & Undifferentiated & $\mathrm{Ku}$ & $1,590-2,950$ & -- & \\
\hline & \multirow{8}{*}{$\begin{array}{l}.0 \\
0 \\
\frac{0}{0} \\
\frac{0}{\pi}\end{array}$} & \multirow[t]{3}{*}{ Permian } & $\begin{array}{l}\text { San Andres } \\
\text { Limestone }\end{array}$ & Psa & $2,950-3,690$ & $\begin{array}{l}\text { Marine porous and permeable } \\
\text { sandstone and limestone. Dark } \\
\text { carbonaceous and bituminous } \\
\text { matter }\end{array}$ & $\begin{array}{l}\text { Irrigation wells can yield } 800 \text { to } 1,000 \mathrm{gal} / \mathrm{min}^{1}{ }^{1} \\
\text { Transmissivity of } 75,000(\mathrm{gal} / \mathrm{d}) / \mathrm{ft}^{2}\end{array}$ \\
\hline & & & Yeso Formation & Py & $3,690-5,439$ & $\begin{array}{l}\text { Porous and permeable sandstone and } \\
\text { limestone }\end{array}$ & $\begin{array}{l}\text { Stock wells can yield } 3 \text { to } 15 \mathrm{gal} / \mathrm{min}^{2}{ }^{2} \\
\text { Transmissivity of } 44,750(\mathrm{gal} / \mathrm{d}) / \mathrm{ft}^{2}\end{array}$ \\
\hline & & & Abo Formation & $\mathrm{Pa}$ & $5,439-6,608$ & Sandstone redbeds & $\begin{array}{l}\text { Springs and groundwater wells can yield } 3 \text { to } \\
4 \mathrm{gal} / \mathrm{min}^{2}\end{array}$ \\
\hline & & \multirow[t]{2}{*}{ Pennsylvanian } & Undifferentiated & $\mathrm{Pu}$ & $6,608-6,702$ & -- & \multirow[t]{2}{*}{ Yield small amounts of water. $^{2}$} \\
\hline & & & $\begin{array}{l}\text { Magdalena } \\
\text { Formation }\end{array}$ & $\mathrm{Pm}$ & $6,702-8,306$ & $\begin{array}{l}\text { Marine blue and gray limestone. } \\
\text { Dark blue shale. Carbonaceous and } \\
\text { petroliferous residues }\end{array}$ & \\
\hline & & Mississippian & Undifferentiated & M & $8,306-8,350$ & $\begin{array}{l}\text { Limestone and quartzite sill. The sill } \\
\text { is } \sim 500 \text { feet thick }\end{array}$ & Unknown. \\
\hline & & Devonian & Percha Shale & $\mathrm{Dp}$ & $8,350-8,500$ & Shale & Unknown. \\
\hline & & Silurian & $\begin{array}{l}\text { Fusselman } \\
\text { Dolostone }\end{array}$ & Sf & 8,500-unknown & Dolomite & Unknown. \\
\hline
\end{tabular}


Table 1. Summary of hydrostratigraphic nomenclature and description of rock units in areas of interest, Jornada del Muerto, Tularosa Basin, and Otero Mesa, New Mexico.Continued

[Locations of geologic cross sections and wells shown in figure 9; ft, foot; API, American Petroleum Institute. gal/min, gallon per minute; --, no data; (gal/d)/ft, gallons per day per foot; , approximately]

Wells located on cross section $A-A^{\prime}-$ Continued

Well log information from the Jornada del Muerto high oil and gas occurrence potential area-Continued

Well API 30-051-20008 Well \#3

\begin{tabular}{|c|c|c|c|c|c|c|c|}
\hline $\begin{array}{l}\text { Eonothem/ } \\
\text { eon }\end{array}$ & $\begin{array}{l}\text { Erathem/ } \\
\text { era }\end{array}$ & $\begin{array}{c}\text { System/ } \\
\text { subsystem/ } \\
\text { period/subperiod }\end{array}$ & $\begin{array}{l}\text { Geologic } \\
\text { unit }\end{array}$ & Abbreviation & $\begin{array}{l}\text { Depth from } \\
\text { surface } \\
\text { (ft) }\end{array}$ & $\begin{array}{c}\text { Unit } \\
\text { description }\end{array}$ & Hydrogeologic characteristics \\
\hline \multirow{5}{*}{$\begin{array}{l}\frac{0}{0} \\
0 \\
\frac{0}{0} \\
\frac{0}{2} \\
\frac{0}{2}\end{array}$} & $\begin{array}{l}0 \\
0 \\
0 \\
0 \\
0 \\
0\end{array}$ & Quaternary & & Qal & $0-5,128$ & Sand, gravel, and redbeds & Permeable; irrigation wells yield $1,000 \mathrm{gal} / \mathrm{min}^{1}{ }^{1}$ \\
\hline & \multirow{4}{*}{$\begin{array}{l}0 \\
0 \\
0 \\
\frac{0}{\pi} \\
\frac{0}{0}\end{array}$} & Pennsylvanian & Undifferentiated & $\mathrm{P}$ & $5,128-6,728$ & Limestone and shale & Yield small amounts of water. ${ }^{2}$ \\
\hline & & \multirow[t]{2}{*}{ Ordovician } & Montoya Group & $\mathrm{O}$ & $6,728-6,906$ & Dolomite & Unknown. \\
\hline & & & El Paso Group & $\mathrm{O}$ & $6,906-7,334$ & $\begin{array}{l}\text { Sandstone, dolomite, and } \\
\text { limestone }\end{array}$ & Unknown. \\
\hline & & $\begin{array}{l}\text { Cambro- } \\
\text { Ordovician }\end{array}$ & Bliss Sandstone & $\mathrm{OC}$ & $7,334-7,462$ & $\begin{array}{l}\text { Sandstone, limestone, and } \\
\text { dolomite }\end{array}$ & $\begin{array}{l}\text { Relatively impermeable. }{ }^{1} \text { Porosity is } 3.4 \text { to } \\
7.6 \text { percent. }{ }^{3}\end{array}$ \\
\hline $\begin{array}{l}0 \\
0 \\
0 \\
0 \\
00 \\
0 \\
0 \\
0\end{array}$ & & Precambrian & & $\mathrm{pC}$ & $7,462-7,552$ & Crystalline rock & Relatively impermeable. ${ }^{1}$ \\
\hline
\end{tabular}


Table 1. Summary of hydrostratigraphic nomenclature and description of rock units in areas of interest, Jornada del Muerto, Tularosa Basin, and Otero Mesa, New Mexico.Continued

[Locations of geologic cross sections and wells shown in figure 9; ft, foot; API, American Petroleum Institute. gal/min, gallon per minute; --, no data; (gal/d)/ft, gallons per day per foot; , approximately]

Wells located on cross section $A-A^{\prime}-$ Continued

Well log information from the Tularosa Basin high oil and gas occurrence potential area

Well API 30-035-20015 Well \#4

\begin{tabular}{|c|c|c|c|c|c|c|c|}
\hline $\begin{array}{l}\text { Eonothem/ } \\
\text { eon }\end{array}$ & $\begin{array}{l}\text { Erathem/ } \\
\text { era }\end{array}$ & $\begin{array}{c}\text { System/ } \\
\text { subsystem/ } \\
\text { period/subperiod }\end{array}$ & $\begin{array}{l}\text { Geologic } \\
\text { unit }\end{array}$ & Abbreviation & $\begin{array}{l}\text { Depth from } \\
\text { surface } \\
\text { (ft) }\end{array}$ & $\begin{array}{c}\text { Unit } \\
\text { description }\end{array}$ & Hydrogeologic characteristics \\
\hline \multirow{5}{*}{ 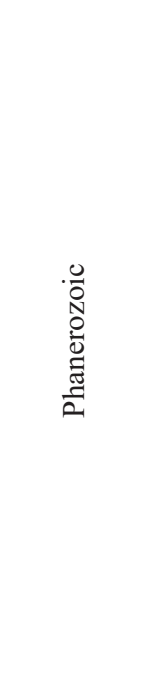 } & 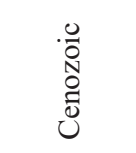 & Quaternary & Alluvium & Qp & $0-3,900$ & Valley fill, piedmont alluvial deposits & $\begin{array}{l}\text { Permeable; irrigation wells yield 1,000 gal/ } \\
\text { min. }{ }^{1}\end{array}$ \\
\hline & $\begin{array}{l}0 \\
0 \\
0 \\
0 \\
\infty \\
\sum_{2}^{\infty}\end{array}$ & Cretaceous & $\begin{array}{l}\text { Dakota } \\
\text { Sandstone }\end{array}$ & $\mathrm{Kd}$ & $3,900-6,700$ & Brown to white sandstone & $\begin{array}{l}\text { Groundwater wells can yield } 2-500 \mathrm{gal} / \\
\text { min. }{ }^{2}\end{array}$ \\
\hline & \multirow{3}{*}{$\begin{array}{l}0 \\
\frac{0}{0} \\
\frac{0}{\pi} \\
\frac{0}{\pi}\end{array}$} & \multirow[t]{3}{*}{ Permian } & $\begin{array}{l}\text { San Andres } \\
\text { Limestone }\end{array}$ & Psa & $6,700-7,300$ & $\begin{array}{l}\text { Gray fossiliferous limestone and } \\
\text { dolomite }\end{array}$ & $\begin{array}{l}\text { Irrigation wells can yield } 800 \text { to } 1,000 \mathrm{gal} / \\
\text { min. }{ }^{1} \text { Transmissivity of } 75,000(\mathrm{gal} / \mathrm{d}) / \mathrm{ft}^{2}{ }^{2}\end{array}$ \\
\hline & & & $\begin{array}{l}\text { Glorieta } \\
\text { Sandstone }\end{array}$ & $\mathrm{Pg}$ & $7,300-7,390$ & Quartz sandstone & Unknown. \\
\hline & & & $\begin{array}{l}\text { Yeso } \\
\text { Formation }\end{array}$ & Py & $7,390-8,900$ & $\begin{array}{l}\text { Gypsum, yellow sandstones, red/yellow/ } \\
\text { gray siltstones/shales, limestone, } \\
\text { dolomite, minor halite }\end{array}$ & $\begin{array}{l}\text { Stock wells can yield } 3 \text { to } 15 \mathrm{gal} / \mathrm{min}^{2}{ }^{2} \\
\text { Transmissivity of } 44,750(\mathrm{gal} / \mathrm{d}) / \mathrm{ft}^{2}\end{array}$ \\
\hline 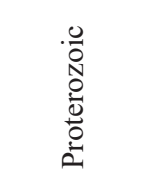 & & Precambrian & & $\mathrm{Xg}$ & 8,900-unknown & Coarse, pink granitic rocks & Relatively impermeable. ${ }^{1}$ \\
\hline
\end{tabular}


Table 1. Summary of hydrostratigraphic nomenclature and description of rock units in areas of interest, Jornada del Muerto, Tularosa Basin, and Otero Mesa, New Mexico.Continued

[Locations of geologic cross sections and wells shown in figure 9; ft, foot; API, American Petroleum Institute. gal/min, gallon per minute; --, no data; (gal/d)/ft, gallons per day per foot; , approximately]

Wells located on cross section $A-A^{\prime}-$ Continued

Well log information from the Tularosa Basin high oil and gas occurrence potential area-Continued

Well API derived from 30-035-20025 and 30-035-20011 Wells \#5 and 6

\begin{tabular}{|c|c|c|c|c|c|c|c|}
\hline $\begin{array}{l}\text { Eonothem/ } \\
\text { eon }\end{array}$ & $\begin{array}{l}\text { Erathem/ } \\
\text { era }\end{array}$ & $\begin{array}{c}\text { System/ } \\
\text { subsystem/ } \\
\text { period/subperiod }\end{array}$ & $\begin{array}{l}\text { Geologic } \\
\text { unit }\end{array}$ & Abbreviation & $\begin{array}{l}\text { Depth from } \\
\text { surface }\end{array}$ & $\begin{array}{c}\text { Unit } \\
\text { description }\end{array}$ & Hydrogeologic characteristics \\
\hline \multirow{8}{*}{ 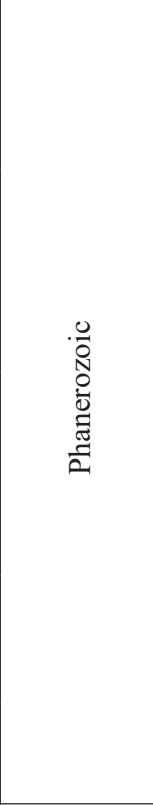 } & $\begin{array}{l}0 \\
\stackrel{0}{0} \\
\end{array}$ & Quaternary & Alluvium & Qa & $0-918$ & $\begin{array}{l}\text { Alluvial deposits with Tertiary intermediate to } \\
\text { silicic igneous sill }\end{array}$ & $\begin{array}{l}\text { Permeable; irrigation wells yield } 1,000 \\
\text { gal } / \text { min. }^{1}\end{array}$ \\
\hline & \multirow{7}{*}{$\begin{array}{l}0 \\
0 \\
0 \\
0 \\
\frac{0}{\pi} \\
0\end{array}$} & Permian & Abo Formation & $\mathrm{Pa} \& \mathrm{~Pb}$ & $918-1,695$ & $\begin{array}{l}\text { Arkosic sandstone to pebble conglomerate beds, } \\
\text { sandy limestone, nodular limestone wedge }\end{array}$ & $\begin{array}{l}\text { Springs and groundwater wells can } \\
\text { yield } 3 \text { to } 4 \mathrm{gal} / \mathrm{min}^{2}\end{array}$ \\
\hline & & Pennsylvanian & Undifferentiated & $\mathrm{Pu}$ & $1,695-3,300$ & $\begin{array}{l}\text { Marine shales, limestones, carbonates, and } \\
\text { clastics }\end{array}$ & Yield small amounts of water. ${ }^{2}$ \\
\hline & & Mississippian & $\begin{array}{l}\text { Lake Valley } \\
\text { Limestone }\end{array}$ & M & $3,330-3,705$ & $\begin{array}{l}\text { Crinoidal limestones, calcareous siltstone, and } \\
\text { shale }\end{array}$ & Unknown. \\
\hline & & Silurian & $\begin{array}{l}\text { Fusselman } \\
\text { Dolostone }\end{array}$ & $\mathrm{S}$ & $3,705-3,930$ & Dark, cherty dolomite & Unknown. \\
\hline & & \multirow[t]{2}{*}{ Ordovician } & Montoya Group & $\mathrm{O}$ & $3,930-4,270$ & Dolomite, chert, and sandy dolomite & Unknown. \\
\hline & & & El Paso Group & $\mathrm{O}$ & $4,270-4,410$ & Alternating limestones and dolomites & Unknown. \\
\hline & & $\begin{array}{l}\text { Cambro- } \\
\text { Ordovician }\end{array}$ & Bliss Sandstone & $\mathrm{OC}$ & $4,410-4,500$ & Sandstone with glauconitic, oolitic hematite beds & $\begin{array}{l}\text { Relatively impermeable }{ }^{1} \text {. Porosity is } 3.4 \\
\text { to } 7.6 \text { percent. }^{3}\end{array}$ \\
\hline $\begin{array}{l}.0 \\
0 \\
0 \\
00 \\
0 \\
0 \\
0 \\
0\end{array}$ & & Precambrian & & $\mathrm{Xg}$ & $4,500-5,020$ & Coarse, pink granitic rocks & Relatively impermeable. ${ }^{1}$ \\
\hline
\end{tabular}


Table 1. Summary of hydrostratigraphic nomenclature and description of rock units in areas of interest, Jornada del Muerto, Tularosa Basin, and Otero Mesa, New Mexico.Continued

[Locations of geologic cross sections and wells shown in figure 9; ft, foot; API, American Petroleum Institute. gal/min, gallon per minute; --, no data; (gal/d)/ft, gallons per day per foot; , approximately]

Wells located on cross section $D-D^{\prime}$

Well log information from the Otero Mesa high oil and gas occurrence potential area

Well API 30-035-00012 Well \#9

\begin{tabular}{|c|c|c|c|c|c|c|c|}
\hline $\begin{array}{l}\text { Eonothem/ } \\
\text { eon }\end{array}$ & $\begin{array}{c}\text { Erathem/ } \\
\text { era }\end{array}$ & $\begin{array}{c}\text { System/ } \\
\text { subsystem/ } \\
\text { period/subperiod }\end{array}$ & $\begin{array}{l}\text { Geologic } \\
\text { unit }\end{array}$ & Abbreviation & $\begin{array}{l}\text { Depth from } \\
\text { surface } \\
\text { (ft) }\end{array}$ & $\begin{array}{c}\text { Unit } \\
\text { description }\end{array}$ & Hydrogeologic characteristics \\
\hline \multirow{9}{*}{ 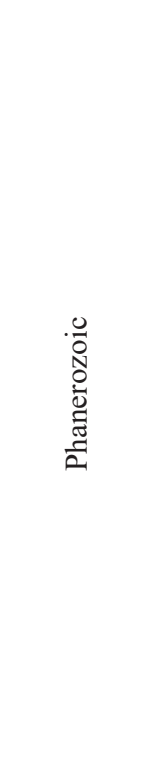 } & \multirow{9}{*}{$\begin{array}{l}0 \\
0 \\
0 \\
0 \\
0 \\
0 \\
0\end{array}$} & Quaternary & & Qa & $0-50$ & Sand & Permeable; irrigation wells yield $1,000 \mathrm{gal} / \mathrm{min}^{1}$ \\
\hline & & \multirow{5}{*}{ Permian } & $\begin{array}{l}\text { San Andres } \\
\text { Limestone }\end{array}$ & Psa & $50-1,050$ & $\begin{array}{l}\text { Gray fossiliferous limestone and } \\
\text { dolomite }\end{array}$ & $\begin{array}{l}\text { Irrigation wells can yield } 800 \text { to } 1,000 \mathrm{gal} / \mathrm{min}^{1} \\
\text { Transmissivity of } 75,000(\mathrm{gal} / \mathrm{d}) / \mathrm{ft}^{2}{ }^{2}\end{array}$ \\
\hline & & & Yeso Formation & Py & $1,050-1,372$ & $\begin{array}{l}\text { Red shale, sands, limestone, and } \\
\quad \text { evaporites }\end{array}$ & $\begin{array}{l}\text { Stock wells can yield } 3 \text { to } 15 \mathrm{gal} / \mathrm{min}^{2}{ }^{2} \\
\text { Transmissivity of } 44,750(\mathrm{gal} / \mathrm{d}) / \mathrm{ft}^{2}\end{array}$ \\
\hline & & & Abo Formation & $\mathrm{Pa}$ & $1,372-1,546$ & $\begin{array}{l}\text { Red mudstone, shale, and } \\
\text { dolomite }\end{array}$ & $\begin{array}{l}\text { Springs and groundwater wells can yield } 3 \text { to } \\
4 \mathrm{gal} / \mathrm{min}^{2}{ }^{2}\end{array}$ \\
\hline & & & \multirow[t]{2}{*}{ Hueco Formation } & \multirow[t]{2}{*}{$\mathrm{Ph}$} & $1,546-2,090$ & $\begin{array}{l}\text { Dolomite, limestone, and red } \\
\text { shale }\end{array}$ & Unknown. \\
\hline & & & & & $2,090-2,104$ & Conglomerate & Unknown. \\
\hline & & Mississippian & Undifferentiated & M & $2,104-2,146$ & $\begin{array}{l}\text { Crinoidal and shelf limestones, } \\
\text { chert }\end{array}$ & Unknown. \\
\hline & & Devonian & Percha Shale & $\mathrm{Dp}$ & $2,146-2,154$ & Fissile shale & Unknown. \\
\hline & & Silurian & $\begin{array}{l}\text { Fusselman } \\
\text { Dolostone }\end{array}$ & $\mathrm{S}$ & $2,154-2,433$ & $\begin{array}{l}\text { Light colored chert, dolomite, } \\
\text { and massive limestone }\end{array}$ & Unknown. \\
\hline
\end{tabular}


Table 1. Summary of hydrostratigraphic nomenclature and description of rock units in areas of interest, Jornada del Muerto, Tularosa Basin, and Otero Mesa, New Mexico.Continued

[Locations of geologic cross sections and wells shown in figure 9; ft, foot; API, American Petroleum Institute. gal/min, gallon per minute; --, no data; (gal/d)/ft, gallons per day per foot; , approximately]

Wells located on cross section $D-D$-Continued

Well log information from the Otero Mesa high oil and gas occurrence potential area-Continued

Well API 30-035-20027 and 30-035-20028 Wells \#7 and 8

\begin{tabular}{|c|c|c|c|c|c|c|c|}
\hline $\begin{array}{c}\text { Eonothem/ } \\
\text { eon }\end{array}$ & $\begin{array}{l}\text { Erathem/ } \\
\text { era }\end{array}$ & \begin{tabular}{|c|} 
System/ \\
subsystem/ \\
period/subperiod
\end{tabular} & $\begin{array}{l}\text { Geologic } \\
\text { unit }\end{array}$ & Abbreviation & $\begin{array}{l}\text { Depth from } \\
\text { surface } \\
\text { (ft) }\end{array}$ & $\begin{array}{c}\text { Unit } \\
\text { description }\end{array}$ & Hydrogeologic characteristics \\
\hline \multirow{13}{*}{ 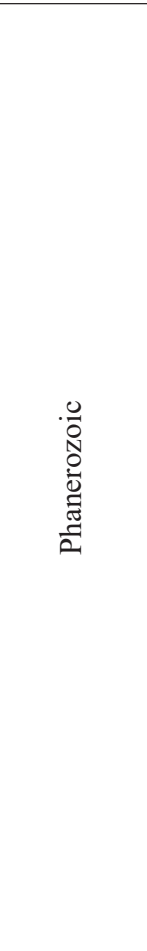 } & \multirow{13}{*}{ 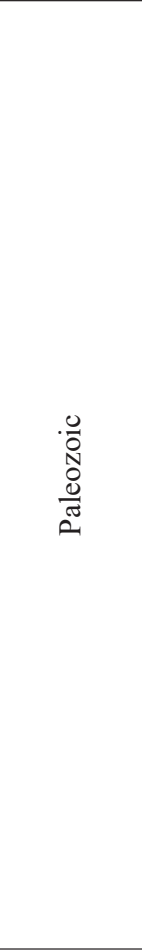 } & \multirow[t]{4}{*}{ Permian } & Yeso Formation & Py & $0-340$ & $\begin{array}{l}\text { Red, gray, yellow shale, yellow } \\
\text { sandstone, limestone, and anhydrite }\end{array}$ & \begin{tabular}{|} 
Stock wells can yield 3 to $15 \mathrm{gal} / \mathrm{min}^{2}$ \\
Transmissivity of $44,750(\mathrm{gal} / \mathrm{d}) / \mathrm{ft}^{2}$
\end{tabular} \\
\hline & & & Abo Formation & $\mathrm{Pa}$ & $340-660$ & Red mudstone, shale, and dolomite & $\begin{array}{l}\text { Springs and groundwater wells can yield } 3 \text { to } \\
4 \mathrm{gal} / \mathrm{min}^{2}{ }^{2}\end{array}$ \\
\hline & & & \multirow{2}{*}{$\begin{array}{l}\text { Hueco } \\
\text { Formation }\end{array}$} & \multirow[t]{2}{*}{$\mathrm{Ph}$} & $660-2,190$ & Dolomite, limestone, and red shale & Unknown. \\
\hline & & & & & $2,190-2,440$ & Conglomerate & Unknown. \\
\hline & & Pennsylvanian & Undifferentiated & $\mathrm{P}$ & $2,440-4,430$ & $\begin{array}{l}\text { Cherty limestone, quartz sandstone, } \\
\text { shale }\end{array}$ & Yield small amounts of water. $^{2}$ \\
\hline & & Mississippian & $\begin{array}{l}\text { Helms } \\
\text { Formation }\end{array}$ & $\mathrm{Mh}$ & $4,430-4,630$ & $\begin{array}{l}\text { Argillaceous limestone with yellow and } \\
\text { gray shale interbedding }\end{array}$ & Unknown. \\
\hline & & & \begin{tabular}{|l|} 
Lower \\
Mississippian
\end{tabular} & M & $4,630-4,905$ & Crinoidal and shelf limestones, chert & Unknown. \\
\hline & & Devonian & Percha Shale & $\mathrm{D}$ & $4,905-4,950$ & Fissile shale & Unknown. \\
\hline & & & Oñate Formation & $\mathrm{D}$ & $4,950-4,975$ & Black chert and limestone, dark shale & Unknown. \\
\hline & & Silurian & $\begin{array}{l}\text { Fusselman } \\
\text { Dolostone }\end{array}$ & $\mathrm{S}$ & $4,975-5,475$ & Chert, dolomite, and massive limestone & Unknown. \\
\hline & & Ordovician & Montoya Group & $\mathrm{O}$ & $5,475-5,820$ & $\begin{array}{l}\text { Sandstone, sandy dolomite, gray cherty } \\
\text { limestone }\end{array}$ & Unknown. \\
\hline & & & El Paso Group & $\mathrm{O}$ & $5,820-6,915$ & Light gray dolomite with some chert & Unknown. \\
\hline & & $\begin{array}{l}\text { Cambro- } \\
\text { Ordovician } \\
\end{array}$ & Bliss Sandstone & $\mathrm{OC}$ & $6,915-7,066$ & Quartz sandstone & \begin{tabular}{|l} 
Relatively impermeable. ${ }^{1}$ Porosity is 3.4 to \\
7.6 percent. \\
\end{tabular} \\
\hline 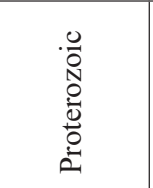 & & Precambrian & Granite & $\mathrm{Xg}$ & $7,066-7,075$ & Coarse-grained igneous intrusive & Relatively impermeable. $^{1}$ \\
\hline
\end{tabular}




\section{$A-A^{\prime}$}

Cross section $A-A^{\prime}$ extends (west to east) from the northcentral part of Sierra County, near Elephant Butte Reservoir, to the north-central part of Otero County, near the Sierra Blanca (fig. 10A). The cross section passes through uplifts of the Fra Cristobal Range, San Andres Mountains, and Sierra Blanca and through intervening valleys of the Jornada del Muerto and Tularosa Basin. Starting in the west, the cross section passes through the Quaternary Cuchillo Negro fault zone, a series of north- to northeast-trending, high-angle, east- and west-dipping normal faults in the central part of the Engle Basin (Lozinsky, 1987; Machette, 1987; Cikoski and Koning, 2013; Machette and Jochems, 2016a). The Engle Basin is an east-tilted half graben filled with as much as 2,300 ft or more of Santa Fe Group sediments along its eastern boundary at the Hot Springs fault system (Lozinsky, 1987). Well API number 30-051-20009 is probably located in the buried section of the northeast-tilted block of the Mud Springs uplift, which is bounded on the west by the Quaternary, highangle, west-dipping Mud Springs fault that could have as much as 6,500 ft of down-to-the-west offset (Lozinsky, 1987; Jochems and Koning, 2015; Machette and Jochems, 2016b). A major, unnamed down-to-the-east normal fault is possible on the east side of the Mud Springs uplift between well API numbers 30-051-20009 and 30-051-00007 (Lozinsky, 1987). Cretaceous rocks are not present on the Mud Springs uplift, likely because of pre-Santa Fe Group erosion (Lozinsky, 1987).

To the east of Elephant Butte Reservoir, the north- to northeast-striking Laramide-age to Rio Grande rift-age Hot Springs fault system of Harrison and Cather (2004) juxtaposes younger Cenozoic basin-fill and Cretaceous strata to the west with older Cretaceous, and Paleozoic rocks along the western flank of the Fra Cristobal Range (NMBGMR, 2003; Nelson and others, 2012; Machette and Jochems, 2016c). The Hot Springs fault within this system dips about 70 to $80^{\circ}$ to the northwest and has at least 3,600 ft of down-to-the-west offset (Lozinsky, 1987; Harrison and Cather, 2004; Nelson and others, 2012; Machette and Jochems, 2016c). Along the eastern flank of the Fra Cristobal Range, the Rio Grande riftage Fra Cristobal fault separates the east-tilted horst of the range from the gentle Cenozoic syncline of the Jornada del Muerto (Lozinsky, 1987; Nelson and others, 2012; Machette and Jochems, 2016d). The Fra Cristobal fault has at least 1,150 ft of down-to-the-east offset that juxtaposes Permian and Pennsylvanian strata west of the fault with Cretaceous and Permian strata east of the fault, and dips about 50 to $70^{\circ}$ to the east (NMBGMR, 2003; Nelson and others, 2012).

Cenozoic basin-fill deposits along $A-A^{\prime}$ in this part of the Jornada del Muerto are relatively thin and generally less than $330 \mathrm{ft}$ thick (Nelson, 1986; Lozinsky, 1987). The gently west-tilted (10 to $20^{\circ}$ ) San Andres Mountains uplift rises along the limb of the Jornada del Muerto syncline and is dissected by a series of unnamed faults assumed to be high-angle, down-to-the-west normal faults that juxtapose younger Santa Fe Group sediments and Cretaceous and Permian rocks to the west with older Permian and Pennsylvanian strata to the east (Kottlowski, 1955; NMBGMR, 2003; Newton and others, 2015). Tertiary intrusive rocks are the cores of peaks in the San Andres Mountains (NMBGMR, 2003).

Cross section $A-A^{\prime}$ extends out of the San Andres Mountains into the northern part of the Tularosa Basin along the northern section of the Rio Grande rift-age San Andres Mountains fault, a northeast-trending, high-angle, down-tothe-east normal fault that juxtaposes lower Paleozoic and Precambrian rocks west of the fault with Cenozoic basin fill east of the fault (NMBGMR, 2003; Machette and Jochems, 2015a). Within this part of the Tularosa Basin, cross section $A-A^{\prime}$ passes through the southern edge of the Carrizozo Basalt, a basaltic lava flow with an eruption age of 5,200 \pm 700 years ago (Dunbar, 1999). The thickness of Cenozoic basin-fill within the Tularosa Basin is poorly documented (Newton and Allen, 2014). However, 3,900 ft of basin-fill was reported above Cretaceous rocks in well API number 30-035-20015 along the eastern margin of the Tularosa Basin. The Tularosa Basin is bounded on the east by the Alamogordo fault, a northwest-trending, high-angle, down-to-the-west normal fault with four sections (Mamer and others, 2014; Koning and others, 2016a). Cross section A-A' passes through the Three Rivers section of the Rio Grande rift-age Alamogordo fault, where it juxtaposes Cenozoic basin-fill west of the fault with Cretaceous and Permian rocks east of the fault (NMBGMR, 2003; Koning and others, 2016a). The difference in elevation between the top of Permian rocks in well API number 30-03520015 west of the Three Rivers section and well API number 30-035-20010 east of the Three Rivers section suggests approximately $6,000 \mathrm{ft}$ of offset. Tertiary intrusive rocks core peaks in the Sierra Blanca (NMBGMR, 2003).

\section{$B-B^{\prime}$}

Cross section $B-B^{\prime}$ extends (west to east) from the south-central part of Sierra County in the Palomas Basin to the central part of Otero County in the Sacramento Mountains (fig. 10B). The cross section passes through uplifts of the Caballo, San Andres, and Sacramento Mountains and through the intervening valleys of the Palomas Basin (Rincon Valley), Jornada del Muerto, and Tularosa Basin. Starting in the west, the cross section is located in the Palomas Basin, an east-tilted half graben filled with at least 6,500 ft of Cenozoic basinfill along the eastern side (Nelson, 1986; Lozinsky, 1987). The eastern margin of the Palomas Basin is bounded by Rio Grande rift-age down-to-the-west normal faults, Derry and Red Hills, that are associated with the southern end of the Caballo Mountains uplift (Machette and Jochems, 2016e-f; Sweetkind, 2017). The Derry fault of Sweetkind (2017) includes a north-trending northward extension of the trace of this fault from Haller (2014) that intersects cross section B-B' south of the Caballo Reservoir. The north-trending Red Hills fault dips 50 to $60^{\circ}$ to the west and juxtaposes Cenozoic basinfill to the west with Paleozoic and Precambrian rocks to the east in the Red Hills uplift (NMBGMR, 2003; Machette and Jochems, 2016f). 
The northwest-trending, high-angle, southern section of the Caballo fault passes through cross section B-B' and bounds the southern end of the east-tilted Caballo Mountains block where it juxtaposes Tertiary sedimentary rocks to the west with Paleozoic rocks to the east (Machette, 1987; NMBGMR, 2003; Machette and Jochems, 2016g). Strata of the Caballo Mountains uplift dip eastward into the syncline of the Jornada del Muerto (Newton and others, 2015). The northwest-trending, down-to-the-east Jornada Draw fault generally parallels the hinge of the syncline and dips to the northeast (Machette and Jochems, 2015b; Newton and others, 2015). Where the Jornada Draw fault intersects cross section $B-B^{\prime}$, it is concealed beneath Quaternary basin-fill deposits (NMBGMR, 2003; Machette and Jochems, 2015b; Newton and others, 2015). The thickness of Cenozoic basin-fill in this part of the Jornada del Muerto ranges from 2,500 $\mathrm{ft}$ to more than 3,500 ft (Hawley and Kennedy, 2004; Kambhammettu and others, 2010). The West San Andres fault zone of Sweetkind and others (2017) passes through cross section B-B' just east of the Jornada Draw fault. The down-to-thewest West San Andres fault zone forms the eastern boundary of the Jornada del Muerto, offsets Middle Santa Fe (Rincon Valley Formation) and older strata, and is buried by Cenozoic basin fill (Hawley and Kennedy, 2004; Sweetkind, 2017).

The gently west-tilted San Andres Mountains uplift rises along the limb of the Jornada del Muerto syncline and is dissected by a series of unnamed faults that are assumed to be high-angle and juxtapose Paleozoic and Precambrian rocks (NMBGMR, 2003; Newton and others, 2015). The San Andres Mountains along cross section B-B' are bounded by the central section of the San Andres Mountains fault. The San Andres Mountains fault trends northwest in this section, but otherwise has similar characteristics to the northern section along cross section A-A' (NMBGMR, 2003; Machette and Jochems, 2015c). The Tularosa Basin is structurally divided into two half grabens by the concealed, north-trending Jarilla fault, with the half grabens tilted away from the fault (Mamer and others, 2014; Newton and Allen, 2014). In this part of the Tularosa Basin, Cenozoic basin-fill thickness ranges from 3,000 to $8,000 \mathrm{ft}$, with basin-fill thickness increasing eastward in the eastern half graben (King and Harder, 1985; Mamer and others, 2014; Newton and Allen, 2014). Cross section B-B' passes through the Sabinata section of the Alamogordo fault, where it juxtaposes Cenozoic basin fill west of the fault with Paleozoic rocks east of the fault at the base of the Sacramento Mountains (NMBGMR, 2003; Koning and others, 2016b). The western escarpment of the Sacramento Mountains exposes Permian and Pennsylvanian strata.

\section{$C-C^{\prime}$}

Cross section $C-C^{\prime}$ extends (west to east) from the westcentral part of Doña Ana County in the Mimbres Basin to the east-central part of Otero County (fig. 10C). The cross section passes through uplifts of the Robledo, Organ, Sacramento, and Guadalupe Mountains and through intervening valleys of the
Mimbres Basin, Mesilla Basin, Jornada del Muerto, Tularosa Basin, and Salt Basin. Starting in the west, the cross section is located in the Mason Draw section of the Mimbres Basin (Hanson and others, 1994; Hawley and others, 2000). The north-trending, down-to-the-east, Rio Grande rift-age Ward Tank fault bounds the east side of the northwest-tilted Sierra de las Uvas uplift, dips 65 to $75^{\circ}$ to the east, and displaces Tertiary and Permian rocks with a maximum offset of 2,000 to 2,500 ft (Machette and Jochems, 2016h). East of the Ward Tank fault, the cross section passes through the Rough and Ready Hills, which contain Oligocene volcanics associated with intrusions of the Cedar Hills vent zone, and the Corralitos graben, which contains Cenozoic basin fill (Seager and Clemons, 1975; Mack and others, 1994; Seager and others, 2004). The Corralitos graben is bounded on the east by the southward-widening horst block of the Robledo Mountains, which has a western margin formed by the West Robledo fault and an eastern margin formed by the East Robledo fault (Seager and others, 2004; Machette and Jochems, 2015d-e). The Rio Grande rift-age West and East Robledo faults are normal faults that trend northeast, dip at high angles to the west and east, respectively, and juxtapose Paleozoic rocks in the horst against Cenozoic basin fill to the west and east, respectively (NMBGMR, 2003; Machette and Jochems, 2015d-e).

Cross section $C-C^{\prime}$ then passes into the northern part of the Mesilla Basin, just north of Las Cruces, New Mexico, where it intersects the north-trending, high-angle, down-to-thewest normal faults of the Mesilla Valley fault zone (Hawley and Kennedy, 2004; Seager and others, 2004; Sweetkind, 2017). The Mesilla Valley fault zone offsets Middle Santa $\mathrm{Fe}$ and older strata, is concealed beneath younger Cenozoic basin fill, and forms the eastern boundary of the Mesilla Basin (Hawley and Kennedy, 2004; Sweetkind, 2017). The Santa Fe Group within this portion of the Mesilla Basin is as much as 2,000 ft thick (Hawley and Kennedy, 2004). To the east of the Mesilla Valley fault zone, the cross section passes through the southern part of the uplift associated with the Tortugas-Doña Ana uplift (Hawley and Kennedy, 2004; Seager and others, 2004; Sweetkind, 2017). The Tortugas-Doña Ana uplift is bounded on the east by the curvilinear Jornada fault zone; in the area where it intersects cross section $C-C^{\prime}$, the Jornada fault zone trends northerly. The Jornada fault zone forms the western boundary of the Jornada del Muerto (Hawley and Kennedy, 2004; Seager and others, 2004). The Rio Grande rift-age Jornada fault zone consists of high-angle, down-tothe-east normal faults (Hawley and Kennedy, 2004; Seager and others, 2004).

Cross section $C-C^{\prime}$ passes through the far southern part of the Jornada del Muerto, which is filled with approximately 2,000 to $2,500 \mathrm{ft}$ of Santa Fe Group sediments in this area (Hawley and Kennedy, 2004). East of the Jornada del Muerto, cross section $C-C^{\prime}$ intersects the West San Andres fault zone and the west-tilted uplift associated with the Organ Mountains (Seager, 1981; Hawley and Kennedy, 2004; Sweetkind and others, 2017). Tertiary intrusive rocks are the cores of peaks 
in the Organ Mountains (NMBGMR, 2003). The Organ Mountains are bounded on the east by the north-trending, down-to-the-east, Rio Grande rift-age Organ Mountains fault (Machette and Jochems, 2015f). Cross section C $-C^{\prime}$ passes through the Cox Ranch section of the Organ Mountains fault, which dips 60 to $75^{\circ}$ to the east (Machette and Jochems, 2015f). Displacement across this fault is poorly documented, but could be as much as 13,000 to 16,000 ft (Machette and Jochems, 2015f).

The thickness of Cenozoic basin fill within the Tularosa Basin along cross section $C-C^{\prime}$ is poorly documented, but has been estimated to be as much as $6,800 \mathrm{ft}$ and thins to the east (King and Harder, 1985; Newton and Allen, 2014). Cross section $C-C^{\prime}$ passes through the mid-basin Jarilla fault before intersecting the far southern extent of the Alamogordo fault along the southern Sacramento Mountains escarpment. This northeast-trending, high-angle, down-to-the-west, normal fault section of the Alamogordo fault is known as the McGregor section (Koning and others, 2016c). The cross section then passes west to east along the southern part of the Sacramento Mountains just north of the northwest-trending, down-to-the-west system of normal faults and fractures known as the Otero Break (fig. 7) before crossing the Rio Grande rift-age faults that bound the Salt Basin graben and the Guadalupe Mountains uplift to the east (King and Harder, 1985; McKnight, 1986; Mayer, 1995; Mayer and Sharp, 1998; Broadhead, 2003; Ritchie, 2011). The north-trending, high-angle, down-to-the-west Guadalupe fault zone forms the western boundary of the Guadalupe Mountains, with displacement across the fault zone ranging from 2,000 to 4,000 ft (Kelley, 1971; Black, 1973; McKnight, 1986; Ritchie, 2011).

\section{$D-D^{\prime}$}

Cross section $D-D^{\prime}$ extends (west to east) from the southwest part of Doña Ana County in the West Potrillo Mountains to the southeast part of Otero County in the Guadalupe Mountains (fig. 10D). The cross section passes through uplifts of the Franklin, Hueco, Cornudas, and Guadalupe Mountains and through intervening valleys of the Mesilla, Tularosa, and Salt Basins. In addition, the cross section passes through the gently eastward-sloping surface of the Otero Mesa between the Hueco and Cornudas Mountains. Starting in the west, the cross section is located in Quaternary basalt lava flows of the Potrillo volcanic field in the eastern West Potrillo Mountains (Mack and others, 1998; NMBGMR, 2003). The cross section intersects the north-trending, downto-the-east East Potrillo fault zone, which forms the western boundary of the Mesilla Basin in this area (Hawley and Kennedy, 2004; Sweetkind, 2017).

From the East Potrillo fault zone to the Fitzgerald fault, cross section $D-D$ ' passes through the southwestern subbasin of the Mesilla Basin (Hawley and Kennedy, 2004; Sweetkind, 2017). Santa Fe Group thickness within the Southwestern subbasin is generally less than 2,000 ft (Hawley and Kennedy, 2004). The Southwestern subbasin is separated from the
La Union-Mesquite subbasin to the east by the Mid-basin uplift (Hawley and Kennedy, 2004; Sweetkind, 2017). The western boundary of the Mid-basin uplift is defined by the north-trending, high-angle, down-to-the-west Rio Grande riftage Fitzgerald fault (Hawley and Kennedy, 2004; Machette and Jochems, 2015g; Sweetkind, 2017). A poorly defined, north-trending, high-angle, down-to-the-east normal fault zone (Mid-basin fault zone) bounds the eastern side of the Midbasin uplift (Hawley and Kennedy, 2004; Sweetkind, 2017). Santa Fe Group thickness above the Mid-basin uplift is about 1,500 ft (Hawley and Kennedy, 2004).

Santa Fe Group thickness within the La Union-Mesquite subbasin is inferred to reach a maximum of 3,000 ft (Hawley and Kennedy, 2004). The La Union-Mesquite subbasin is bounded on the east by the Mesilla Valley fault zone (Hawley and Kennedy, 2004). The down-to-the-west Three Sisters fault intersects cross section $D-D^{\prime}$ as the cross section approaches the northern Franklin Mountains (Sweetkind and others, 2017). The west-dipping Franklin Mountains uplift is bounded on the east by the concealed southern section of the Artillery Range fault (Harbour, 1972; Lovejoy, 1975; Machette and Jochems, 2015h). In this section, the Rio Grande rift-age Artillery Range fault is a northwest-trending, high-angle, down-to-the-east normal fault (Machette and Jochems, 2015h).

East of the Franklin Mountains, cross section D-D' enters the southern Tularosa Basin/northern Hueco Bolson. The Quaternary Hueco fault zone forms a broad, elongate, north-trending zone of east- and west-dipping normal faults along the western side of the Tularosa Basin/Hueco Bolson in this region (Collins and Jochems, 2016). The Cenozoic basin fill within the Tularosa Basin/Hueco Bolson in this region along cross section $D-D^{\prime}$ has been estimated to be as much as 8,000 ft thick (King and Harder, 1985). At the eastern side of the Tularosa Basin/Hueco Bolson, cross section D-D' intersects an unnamed, southeast-trending, southwest-dipping normal fault of Quaternary age (Machette, 1996). Tertiary intrusive rocks core peaks in the north-south-trending Hueco Mountains (NMBGMR, 2003).

Cross section $D-D^{\prime}$ then passes through the gently eastward-sloping surface of the Otero Mesa. Tertiary intrusive rocks form the cores of peaks in the Cornudas Mountains, which rise more than 2,000 ft above the Otero Mesa along the New Mexico-Texas State line (Ritchie, 2011). The Cornudas Mountains are located above the faulted western edge of the Pedernal uplift (Nutt and O'Neill, 1998; Cather and Harrison, 2002; Broadhead, 2003; Ritchie, 2011). To the east of the Cornudas Mountains, the cross section passes through the Rio Grande rift-age faults that bound the Salt Basin graben and the Guadalupe Mountains uplift to the east (King and Harder, 1985; McKnight, 1986; Mayer, 1995; Mayer and Sharp, 1998; Broadhead, 2003; Ritchie, 2011). These faults include the unnamed western-boundary fault of the Salt Basin graben; the north-trending, down-to-the-west Border fault zone that bounds the eastern edge of the Salt Basin graben; and the north-trending, down-to-the-west Dog Canyon fault zone (King and Harder, 1985; McKnight, 1986; Mayer, 1995; Mayer and Sharp, 1998; Broadhead, 2003; Ritchie, 2011). 


\section{General Stratigraphic and Hydrogeologic Framework in Areas of Interest}

The geologic units in the Tri-County planning area vary in age, rock type, oil and gas potential, and hydrogeologic characteristics. Geologic units in the three areas of interest, Jornada del Muerto, Tularosa Basin, and Otero Mesa, are described in the following sections in order of age from oldest to youngest (fig. 9). Oil and gas potential and hydrogeologic characteristics are included where known. While the detailed geologic descriptions are specific to these areas of interest, the information is generally applicable in other areas of the Tri-County planning area. Stratigraphy and descriptions from selected well logs in each area are shown in table 1. Additionally, table 1 contains available hydrogeologic characteristics of formations described in the well logs. This table and the information in the following sections of text provide more detail about the type of geology present, especially details related to oil and gas development, which could aid land managers when making decisions.

Conventional oil and gas resources are formed when rocks rich in organic material, such as shales, are subjected to heat and pressure which mobilize the hydrocarbons from the rock. The oil or gas then migrates, generally upward, out of the source rock until it hits a seal which traps the oil and gas. Oil and gas are lighter than water and therefore get trapped in a reservoir above the water column. A reservoir, typically composed of a porous media such as sandstone or limestone, is the location where the oil and gas remain until extracted via vertical drilling and pumping (Dolson, 2016). Reservoir rocks can be quantified by values of porosity and permeability. The porosity of a rock quantifies the open space in a rock divided by the total rock volume, and is presented as a percentage. The permeability value of a rock provides an indication of the ability for fluids to flow through pore spaces. These characteristics also apply to water-bearing capabilities of rocks. Oil and gas typically remain in reservoirs until extracted by pumping (Dolson, 2016).

Unconventional oil and gas resources are found in shale source rocks and reservoirs. The hydrocarbons are not trapped on top of the water column and are accessed via horizontal drilling and fracking. Continued advancements in horizontal drilling and production technologies for oil and gas wells, which can extract larger volumes of oil and gas than conventional vertical oil and gas wells, will allow for exploration in areas that have previously been considered not economically feasible. However, little if any oil production is projected for the Tri-County planning area (Glover, 2015).

\section{Precambrian}

The oldest rock units observed in the Tri-County planning area are Precambrian in age and consist of fractured, coarse-grained granite and metamorphic rocks (table 1; Kelley and Silver, 1952; Person and others, 2013). They can be observed along the western escarpment, or long steep slope, of the Sacramento Mountains, in the northern San Andres Mountains, and in various other isolated areas (Weir, 1965). The metamorphic lithology in southern New Mexico is primarily phyllite and schist, while the granite is predominantly quartz monzonite (Stageman, 1988). The Precambrian rocks can be greater than $17,000 \mathrm{ft}$ thick in the subsurface in some areas (Kelley and Silver, 1952).

\section{Oil and Gas Potential}

Rocks of Precambrian age are generally not oil and gas source rocks or reservoir rocks because they have no carbon content and low permeability.

\section{Hydrogeologic Characteristics}

Precambrian rocks in the Tri-County planning area generally yield little to no water because of low permeability, which makes them poor aquifers (Conover and others, 1955; Hood and Kister, 1962; Weir, 1965).

\section{Cambro-Ordovician}

The Bliss Sandstone unconformably overlies the Precambrian-age rocks (table 1; Pray, 1961). The sandstone is estimated to be Late Cambrian to Early Ordovician in age (Kelley and Silver, 1952). The Bliss Sandstone has a distinct dark gray color and a varied composition of alternating siliciclastics and carbonates because it was deposited over one major transgression and four minor regressive-transgressive packages of an ancient seaway (Kelley and Silver, 1952; Chafetz and others, 1986; Stageman, 1988). The deposit consists of coarse-grained sandstone, limestone, dolomite, oolitic hematite, shale, glauconite, siltstone, and a pebble conglomerate near the base of the unit; bedding is thin with a few thicker beds near the base (Kelley and Silver, 1952; Pray, 1961; Stageman, 1988). Overall, the Bliss Sandstone is approximately $110-160 \mathrm{ft}$ thick in south-central New Mexico (Kelley and Silver, 1952).

\section{Oil and Gas Potential}

The Bliss Sandstone contains less than 0.2 percent organic matter, which is low for yielding hydrocarbons (Darton, 1921; Broadhead, 2003).

\section{Hydrogeologic Characteristics}

The Cambrian rocks do not affect the groundwater hydrology in the Tularosa Basin (Weir, 1965). The Bliss Sandstone is relatively impermeable and therefore is not a 
good aquifer (Conover and others, 1955). The porosity of the sandstones in the Bliss Sandstone ranges from 3.4 to 7.6 percent (Hayes, 1975).

\section{Ordovician}

\section{El Paso Group}

The El Paso Group is a thick carbonate sequence that is divided into the Sierrite Limestone and the Bat Cave Formation and is easily distinguishable by color and bedding (Kelley and Silver, 1952; Taylor and others, 2004). The Sierrite Limestone lies conformably over the Bliss Sandstone except near the Sacramento Mountains where a minor unconformity may exist (Pray, 1961; Stageman, 1988). The Sierrite Limestone is gray to brown, the composition is mostly limestone with bands and nodules of chert, and it has thin to medium bedding (Kelley and Silver, 1952; Pray, 1961). The Sierrite Limestone is commonly $130-170 \mathrm{ft}$ thick, but is as much as $430 \mathrm{ft}$ thick near the Sacramento Mountains (Kelley and Silver, 1952; Pray, 1961). The Bat Cave Formation conformably overlies the Sierrite Limestone. Stromatolite bioherms (ancient reefs of mound-like form builtby a variety of marine invertebrates) in the lower Bat Cave Formation separate the Sierrite Limestone and the Bat Cave Formation (Kelley and Silver, 1952). The Bat Cave Formation is gray, the composition is mostly fine-grained limestone and dolomite with some dark brown chert banding and nodules, and it has medium to thick bedding (Kelley and Silver, 1952). The Bat Cave Formation is commonly 215-305 $\mathrm{ft}$ thick with thinning towards the north that has most likely been caused by post-depositional erosion (Kelley and Silver, 1952).

\section{Oil and Gas Potential}

The El Paso Group has total organic carbon concentrations less than 0.2 percent, which is low for yielding hydrocarbons (Broadhead, 2003), but some oil residues have been found in the Jornada del Muerto (Albright and others, 1955). The biohermal masses of ancient stromatolite reefs in some of the Ordovician rocks of the Jornada del Muerto contain secondary porosity (Kelley and Silver, 1952), which increases the likelihood of becoming petroleum reservoirs in the presence of source rocks in the area.

\section{Hydrogeologic Characteristics}

The Ordovician rocks do not have significance to the groundwater hydrology in the Tularosa Basin (Weir, 1965). In general, the rocks have low porosity and permeability. However, the El Paso Group has well-developed secondary porosity from dissolution of limestone and dolomites (Broadhead, 2003).

\section{Montoya Group}

The Montoya Formation was elevated to group status by Kelley and Silver in their paper published in 1952, which was based on previous work by Darton (1928) and Entwistle (1944). The Montoya Group is divided into the Cable Canyon Sandstone, Upham Dolomite, Aleman Formation, and the Cutter Dolomite in south-central New Mexico. Regionally, the Cable Canyon Sandstone unconformably overlies the El Paso Group (Pray, 1961). The Cable Canyon Sandstone is a gray, medium-grained sandstone that coarsens upward into a conglomerate near the top of the unit and forms a cliff at the surface (Kelley and Silver, 1952). The Upham Dolomite conformably overlies the Cable Canyon Sandstone. The Upham Dolomite is a gray to brown, medium- to coarsegrained dolomite with some sparse chert nodules and streaks; it has a high intergranular porosity (Kelley and Silver, 1952). The Aleman Formation is a gray and brown dolomite and is a marker bed for the Montoya Group (Kelley and Silver, 1952). The Aleman Formation is largely microcrystalline with chert fossil replacements (Kelley and Silver, 1952). The Cutter Dolomite rests on an apparent conformity with the Aleman Formation; it is a gray dolomite with dolomitic limestone and claystone at the base of the unit (Kelley and Silver, 1952). The entire Montoya Group is as much as $450 \mathrm{ft}$ thick near the Caballo Mountains and approximately 190 to $225 \mathrm{ft}$ thick in the Sacramento Mountains (Kelley and Silver, 1952; Pray, 1961).

\section{Oil and Gas Potential}

The Cable Canyon Sandstone has high porosity, and some oil residues have been found in the Jornada del Muerto (Albright and others, 1955). The Ordovician Montoya Group has total organic carbon concentrations less than 0.2 percent, which is low for yielding hydrocarbons (Broadhead, 2003).

\section{Hydrogeologic Characteristics}

The Montoya Group has well-developed secondary porosity from dissolution of limestone and dolomites (Broadhead, 2003), which would be expected to promote fluid flow. The Upham Dolomite has a high intergranular (Kelley and Silver, 1952) and vuggy porosity, or porosity formed from dissolution of large features such as fossils (Greenwood and others, 1977). Person and others (2013) used residence time and temperature to determine that lower Paleozoic rocks generally have a porosity of 0.15 and a permeability of $10^{-13.3}$ square meters $\left(\mathrm{m}^{2}\right)$.

\section{Silurian}

The Fusselman Dolostone rests unconformably on the Montoya Group (table 1; Pray, 1961) and is a jointed gray and brown dolomite with some chert banding and nodules 
(Kelley and Silver, 1952). The formation is distinctive in the Sacramento Mountains, can be a ledge former, and is fossiliferous (Pray, 1961). It has variable thicknesses because of erosion, but it can be as much as $75 \mathrm{ft}$ thick and tends to pinch out towards the north in the Tri-County planning area (Pray, 1961; NMOCD, 2016a).

\section{Oil and Gas Potential}

The total organic concentration in the Fusselman Dolostone in the Tularosa Basin is less than 0.2 percent, which is low for a hydrocarbon source rock (Broadhead, 2003); however, the Fusselman Dolostone may still be a good reservoir for oil and gas (Pray, 1961).

\section{Hydrogeologic Characteristics}

The Fusselman Dolostone has well-developed porosity, and freshwater has been recovered in this unit in areas of the Otero Mesa and Tularosa Basin (Broadhead, 2003). However, concentrate water from the desalination plant in El Paso, Texas, is injected into the Fusselman Dolostone in the Hueco Bolson in Texas, close to the New Mexico border. The concentrate water has total dissolved solids less than 8,000 milligrams per liter (mg/L) (Hutchison, 2008).

\section{Devonian}

The Devonian strata in southern New Mexico consist of the Oñate Formation and Percha Shale (table 1). The Oñate Formation is the oldest Devonian section observed in southern New Mexico and was formerly referred to as the Canutillo of Texas (Stevenson, 1945; Pray, 1961). It rests unconformably on the Fusselman Dolostone and is found in the Otero Mesa area in southern New Mexico (Pray, 1961; NMOCD, 2016d). The Oñate Formation is a crystalline black limestone and gray dolomite with chert nodules in the upper portion and dark shale at the base; it has thin bedding and is not fossiliferous (Black, 1975; Pray, 1961). The thickness of the Oñate Formation in the Sacramento Mountains can be as much as $34 \mathrm{ft}$ (Pray, 1961). The Percha Shale rests unconformably on the Oñate Formation in the Sacramento Mountains and Otero Mesa area, but also on the Fusselman Dolostone in other areas (Pray, 1961). It is a slope-former that is a dark brown fissile shale in the lower section, gray claystone with limestone nodules in the middle section, and a fine-grained red sandstone in the upper section (Kelley and Silver, 1952; Pray, 1961).

The Percha Shale has variable thickness but can be as much as $105 \mathrm{ft}$ thick in the Caballo Mountains (Pray, 1961).

\section{Oil and Gas Potential}

In the Jornada del Muerto, the sandstone portion of the Percha Shale has oil reservoir potential, and the shale has oil confinement potential (Albright and others, 1955). Petroleum source rocks in the Tularosa Basin are Devonian shales and cherts, with total organic carbon concentrations ranging from 0.18 to 3.68 percent and thermal maturity ranging from immature to mature (Broadhead, 2003). No information was found about the oil and gas potential of the Oñate Formation.

\section{Hydrogeologic Characteristics}

The Percha Shale is a confining unit in the southern Caballo Mountains with a permeability of $10^{-18.3} \mathrm{~m}^{2}$ and a porosity of 0.15 (Person and others, 2013). The permeability of the Percha Shale is very low, which would make it a poor aquifer. In the case of the Percha Shale, only 15 percent of the rock has open pore space. No information was found about the hydrogeologic characteristics of the Oñate Formation.

\section{Mississippian}

The presence of Mississippian strata in southern New Mexico is spatially variable. The deposits thin towards the south because of the uplift and subsequent erosion that occurred during the late Pennsylvanian period (Black, 1975), so they are not consistently present throughout the Tri-County planning area. The Lower Mississippian sections include the Caballero and Lake Valley Formations; the Lake Valley Formation is further divided into several members, of which the Alamogordo and Nunn Members may be present in the Sacramento Mountains (Pray, 1961). The Caballero Formation sits unconformably on the Percha Shale and is a gray limestone and shale unit with fossils; it can be as much as $15 \mathrm{ft}$ thick south of the Sacramento Mountains (Pray, 1961). The Lake Valley Formation occurs in patches within southern New Mexico (Kelley and Silver, 1952). The Lake Valley Formation is fossiliferous and contains chert lenses and minor shales and siltstones. It can be as much as $400 \mathrm{ft}$ thick near the Sacramento Mountains but thins to the north, and thicknesses are highly variable because of erosional processes (Pray, 1961). The upper strata of the Lake Valley Formation consists of the Helms Formation, present in the southern section of the Otero Mesa (NMOCD, 2016d). The Helms Formation is present in southern Otero Mesa, and it also sits unconformably on the Lower Mississippian units; it is a gray limestone with shale interbedding and oolitic limestone in the upper section (Pray, 1961). It is thin-bedded, fossiliferous and can be as much as $200 \mathrm{ft}$ thick in the southern Otero Mesa area (Pray, 1961; NMOCD, 2016d).

\section{Oil and Gas Potential}

The Helms Formation has had evidence of gas as an escape of methane from underground deposits, in the southern Otero Mesa area (NMOCD, 2016d). Gas shows are thought to indicate the presence of hydrocarbons. No other information regarding oil and gas potential were found for these geologic units. 


\section{Hydrogeologic Characteristics}

No data were found about hydrogeology for these geologic units.

\section{Pennsylvanian}

Pennsylvanian strata are highly variable in southern New Mexico (Kelley and Silver, 1952; Black, 1975). McKee (1967) refers to the presence of thick Pennsylvanian strata that had the opportunity to accumulate in a paleo-basin in south central New Mexico called the Orogrande Basin. The Orogrande Basin has a thick Pennsylvanian sequence that is highly variable because of tectonic instability during the Pennsylvanian period (Wilson, 1967). This tectonic instability caused numerous ancient sea-level transgressions and regressions and also formed the Perdernal uplift to the east of the Orogrande Basin (Wilson, 1967). For this reason, the former Orogrande Basin possesses marine and terrestrial sedimentary deposits (Wilson, 1967). McKee (1967) stated that in the northern area of the Orogrande Basin, the Pennsylvanian strata can be present as the Madera Formation, which is a limestone. The Pennsylvanian strata can be present in the southwest part as the Magdalena Group, and in the southeast as an undifferentiated unit (McKee, 1967). Pennsylvanian strata rest unconformably on the Lower Mississippian section (Kelley and Silver, 1952; Pray, 1961). Pennsylvanian strata thin to the east at the Pedernal uplift (Pray, 1961). Pennsylvanian deposits include fossiliferous white limestone with chert, gray to red sandstone and shale, and a dark limestone conglomerate near the top (where the upper sections are present) (Darton, 1921; Pray, 1961). The Bar B Formation consists of gray shale, siltstone, and mudstone. The thickness of the Pennsylvanian strata can be as much as 3,000 ft in certain areas like the Jornada del Muerto and in the Sacramento Mountains (Pray, 1961).

\section{Oil and Gas Potential}

The Magdalena Group has a high potential for oil and gas because of large amounts of bioherm fossils, high limestone and conglomerate permeability, and shale layer confinements in the Jornada del Muerto (Albright and others, 1955). Oil or gas reservoir rocks in the Tularosa Basin may include rocks of Pennsylvanian age (Butler, 1988).

\section{Hydrogeologic Characteristics}

The Magdalena Group deposits can yield some carbonate-rich water in the Organ Mountain areas (Herrick and Davis, 1965). The Bar B formation has a permeability of $10^{-12} \mathrm{~m}^{2}$, and a porosity of 0.2 ; its low permeability indicates it is more of a confining layer than an aquifer (Person and others, 2013).

\section{Permian}

Permian strata in south-central New Mexico are well preserved. Geologic units include the Hueco Formation (present in the Otero Mesa), Abo Formation, Yeso Formation, Glorieta Formation (present in the Tularosa basin), and the San Andres Limestone (present in the Jornada del Muerto, Tularosa Basin, and northern Otero Mesa) (table 1; Kelley and Silver, 1952; Pray, 1961; NMOCD, 2016d).

The Hueco Formation rests unconformably on the Lower Pennsylvanian strata; it is a gray fossiliferous dolomite and limestone with shale interbedding and some fine-grained sandstone throughout (Black, 1975; Pray, 1961). It also has a conglomerate section near the base of the unit that has previously been referred to as the Powwow Member (Hallgarth, 1967). The Hueco Formation is nearly $1,800 \mathrm{ft}$ thick in the Bennett Ranch area of Otero Mesa (fig. 3; NMOCD, 2016d). The Bennett Ranch has two gas wells that are active, but are shut-in (Glover, 2015). The Hueco Formation is also present south of the Sacramento Mountains as an interbed of gray limestone and shale within the Abo Formation, which is sometimes referred to as the Pendejo Tongue (Black, 1975; Pray, 1961). The Abo Formation rests on an angular unconformity above the Hueco Formation and conformably on the Magdalena Group of Pennsylvanian age in the Caballo Mountains area (Kelley and Silver, 1952; Pray, 1961). The Abo Formation consists of dark red mudstone, claystone, and a medium- to coarse-grained cross-bedded sandstone (Pray, 1961; Black, 1976; Lucas and others, 2014). The unit can be as much as $550 \mathrm{ft}$ thick in southern New Mexico, but thicknesses are highly variable because of structural deformation (Pray, 1961).

The Yeso Formation has a diagnostic pink color that distinguishes it from the red beds of the Abo Formation (Pray, 1961). It rests on a gradational contact between it and the lower Abo Formation (Kelley and Silver, 1952; Pray, 1961). The Yeso Formation has a lithology that is variably erodible and poorly consolidated and consists of fine-grained red to yellow sandstone, gray limestone, gray shale, pink mudstone, gypsum, and halite (Kelley and Silver, 1952; Pray, 1961). The Yeso Formation also has variable thicknesses in southern New Mexico, but can be as much as $1,800 \mathrm{ft}$ thick in the southern Sacramento Mountains (Pray, 1961).

The Glorieta Sandstone is only exposed at the surface in certain central and northern areas of Otero County; it is a light-colored quartz sandstone cemented with calcite (Black, 1975; NMOCD, 2016d).

The San Andres Limestone rests on a gradational contact above the Yeso Formation in most areas (Black, 1975). It is a gray limestone with dolomite and minor amounts of yellowbrown sandstone, red claystone, and gypsum (Kelley and Silver, 1952; Pray, 1961). The San Andres Limestone has thin to medium bedding and is fossiliferous; the thickness is also variable because of erosion but can be as much as $1,000 \mathrm{ft}$, especially in the eastern Tri-County planning area (Kelley and Silver, 1952; Pray, 1961). 


\section{Oil and Gas Potential}

The Yeso Formation and San Andres Limestone have oil reservoir capabilities in the Jornada del Muerto because of their porosity, but they also have carbonaceous material (Albright and others, 1955). In the Otero Mesa area, the entire Permian strata functions as a seal for potential oil reservoirs because of the large unconformity that it lies upon. There is also a high potential for the presence of structural traps below the Permian strata (Black, 1975). The Bennett Ranch has two gas wells that are active, but shut-in, in the Hueco Formation (Glover, 2015).

\section{Hydrogeologic Characteristics}

The Abo Formation has minor groundwater yields in the northern part of the Tularosa Basin (Herrick and Davis, 1965). The Abo Formation has a permeability of $10^{-14.3} \mathrm{~m}^{2}$ and a porosity of 0.25 (Person and others, 2013). The Yeso Formation and Glorieta Sandstone in central New Mexico and south of the New Mexico-Texas border have permeability similar to the range expected in aquifers, but the water quality has been so poor as to be considered generally nonpotable (Herrick and Davis, 1965). In some areas, the Yeso Formation permeability is $10^{-16} \mathrm{~m}^{2}$, and the porosity is 0.25 (Person and others, 2013). The San Andres Limestone can also yield some water in central New Mexico (Herrick and Davis, 1965). The permeability of the San Andres Limestone is relatively low at $10^{-16} \mathrm{~m}^{2}$, and porosity is 0.25 (Person and others, 2013).

\section{Cretaceous}

The Mesozoic strata are confined to the northern extent of the Tri-County planning area and are completely absent to the south because of post-depositional erosion (Black, 1975; Lozinsky, 1987). The remaining units are of Late Cretaceous age and consist of the Dakota Sandstone, Mancos Shale, Mesaverde Formation, and McRae Formation (which is also described as Late Cretaceous to early Tertiary, based on information in the National Geologic Map Database, Geolex Search; USGS, 2017a). The McRae Formation is found in outcrops near Elephant Butte Reservoir, but Kelley and Silver (1952) suggest that it probably extends farther east into the subsurface beneath the Jornada del Muerto. Lozinsky (1987) proposes possible causes of the limited known extent, including a limited area of deposition or perhaps an erosional truncation of the unit that originally extended farther east. The Dakota Sandstone unconformably overlies the San Andres Limestone in the areas where it is present (Kelley and Silver, 1952). The Dakota Sandstone is a fine- to coarse-grained, brown to white sandstone with conglomerates and a lower section of siltstone (Pike, 1947; Kelley and Silver, 1952; Sandeen, 1954). The Dakota Sandstone has thin to medium bedding and cross bedding, and can be as much as $2,800 \mathrm{ft}$ thick east of the Sacramento Mountain escarpment (Kelley and Silver, 1952; NMOCD, 2016d). The Mancos Shale is a dark gray shale unit that has some thin beds of limestone and sandstone (Darton, 1921; Pike, 1947; Kelley and Silver, 1952). It has thin bedding and is typically $350-450 \mathrm{ft}$ thick where it is present in the Tri-County planning area (Kelley and Silver, 1952). The Mesaverde Formation rests conformably on the Mancos Shale; it is a brown unit of interbedded shale, sandstone, and conglomerates (Kelley and Silver, 1952). The Mesaverde Formation can be as much as 2,500 ft thick in the Caballo Mountains, although it is only approximately $50 \mathrm{ft}$ thick in the drill log for well \#2 (API 30-051-00007). The McRae Formation has a rough, uneven lower boundary because of the presence of a basal volcanic conglomerate and is otherwise a medium- to coarse-grained gray sandstone with some reddish brown shale beds (Kelley and Silver, 1952). The McRae Formation is presumed to be as much as 3,000 ft thick in some areas, although measurements have proven difficult because of local faulting and the formation's position under Elephant Butte Reservoir (Kelley and Silver, 1952; Lozinsky and others, 1984).

\section{Oil and Gas Potential}

The Dakota Sandstone may serve as a petroleum reservoir, especially in the Jornada del Muerto area (Darton, 1921; Albright and others, 1955). The Mancos Shale has some sandstone beds that may be coal-bearing, and Darton (1921) states that the Mancos Shale is "favorable for the generation of oil" just northeast of Las Cruces, New Mexico. Since 1922, one abandoned oil well southeast of Las Cruces has shown the presence of oil or gas (Glover, 2015; NMOCD, 2016a). The Mesaverde Formation has had sporadic traces of oil and gas in the Jornada del Muerto likely because of the lenticular nature of individual sand beds; coal beds have also been found within the Mesaverde Formation (Darton, 1921; Albright and others, 1955).

\section{Hydrogeologic Characteristics}

Cretaceous deposits in the study area are overall poor aquifers with the exception of the sandstone units, which are low yielding and contain, in general, nonpotable waters (Herrick and Davis, 1965). However, in the northern Jornada del Muerto, the McRae Formation contains conglomerates, shale, and sandstone as much as 1,500 ft thick, and is an important aquifer unit (Newton and others, 2015).

\section{Quaternary}

The youngest units present in southern New Mexico are of Quaternary age. They are poorly consolidated alluvial sediments and terrace deposits that consist of sands, gravels, conglomerates, red clays, and some gypsum (Darton, 1921; Sandeen, 1954; NMOCD, 2016d). These sediments are present in most areas and can be as much as 5,000 ft thick, especially in larger basins like the Jornada del Muerto and Tularosa Basin (Darton, 1921; Sandeen, 1954; NMOCD, 2016d). 


\section{Oil and Gas Potential}

No literature was found reporting oil and gas possibilities in the Quaternary deposits.

\section{Hydrogeologic Characteristics}

Basin-fill deposits have high water-bearing potential and high yields because they are very permeable, but they are found to be highly mineralized towards basin centers (Herrick and Davis, 1965). This ultimately affects the water quality, which is discussed in the Hydrologic Assessment section of this report.

\section{Hydrologic Assessment}

\section{Surface Water}

Surface water in this discussion was evaluated by 8 -digit hydrologic unit codes (HUC8), where the HUC8 shows a subbasin, regional-scale view of the division of watersheds in the area (fig. 11; USGS and U.S. Department of Agriculture, Natural Resources Conservation Service, 2013). Surface water in the Tri-County planning area is sparse, but important surface-water resources include the Rio Grande, Elephant Butte Reservoir, Caballo Reservoir, Three Rivers, Las Animas Creek, Sacramento River, Tularosa Creek, and Percha Creek (fig. 12). The Rio Grande flows from north to south through Sierra and Doña Ana Counties (fig. 12). In the Salt Basin, the Sacramento River flows from the Sacramento Mountains, where it is perennial, to the south, where it dries up or enters the subsurface (Mayer and Sharp, 1998).

A basic statistical summary of the continuous-record streamgage data is provided in table 2 . The locations of continuous-record streamgages are shown in figure 13, and periods of continuous record are shown in figure 14. Of the 15 continuous-record streamgages, 11 have relatively short periods of record (less than 20 years). Discharge duration curves (fig. 15) provide a visual evaluation of the streamflow characteristics at the streamgages for the periods of available data. Streamgages with pronounced regulation (dams, diversions) affecting the natural streamflow characteristics have distinct duration curves, such as the streamgages on the Rio Grande below Elephant Butte and Caballo Dams (USGS station numbers 08361000 and 08362500 , respectively). Hydrologic alterations caused by irrigation can be more subtle in the duration curve, such as at streamgages 08481500 Tularosa Creek near Bent, 08482000 Rio Tularosa near Tularosa, and $08484500 \mathrm{La} \mathrm{Luz} \mathrm{Creek} \mathrm{at} \mathrm{La} \mathrm{Luz.} \mathrm{The}$ amount of time during which the stream is dry is also an important characteristic of the site. The streamgages 08486250 Tularosa Valley Tributary near White Sands and 08486260 Tularosa Valley Tributary at White Sands were dry more than 95 percent of the time during the period of record.

Four of the 15 continuous-record streamgages have more than 20 years of data, which makes them suitable for in-depth statistical analysis. The two long-term streamgages on the Rio Grande (08361000 and 08362500$)$ are heavily regulated. The other two long-term gages are located on unregulated reaches of Eagle Creek and Tularosa Creek (08387600 and 08481500).

The discharge duration curves provide a visual way to see the overall discharge of each stream as well as how often each stream is flowing at a certain discharge. The long-term discharge data from the four streamgages mentioned above show the inherent variability in streamflows, especially in those streams that are heavily regulated. Many ephemeral channels and arroyos in the Tri-County planning area are not accounted for in this discussion because of lack of data; however, ephemeral channels and arroyos in the Salt Basin may be conduits for basin recharge (Tillery, 2011). 


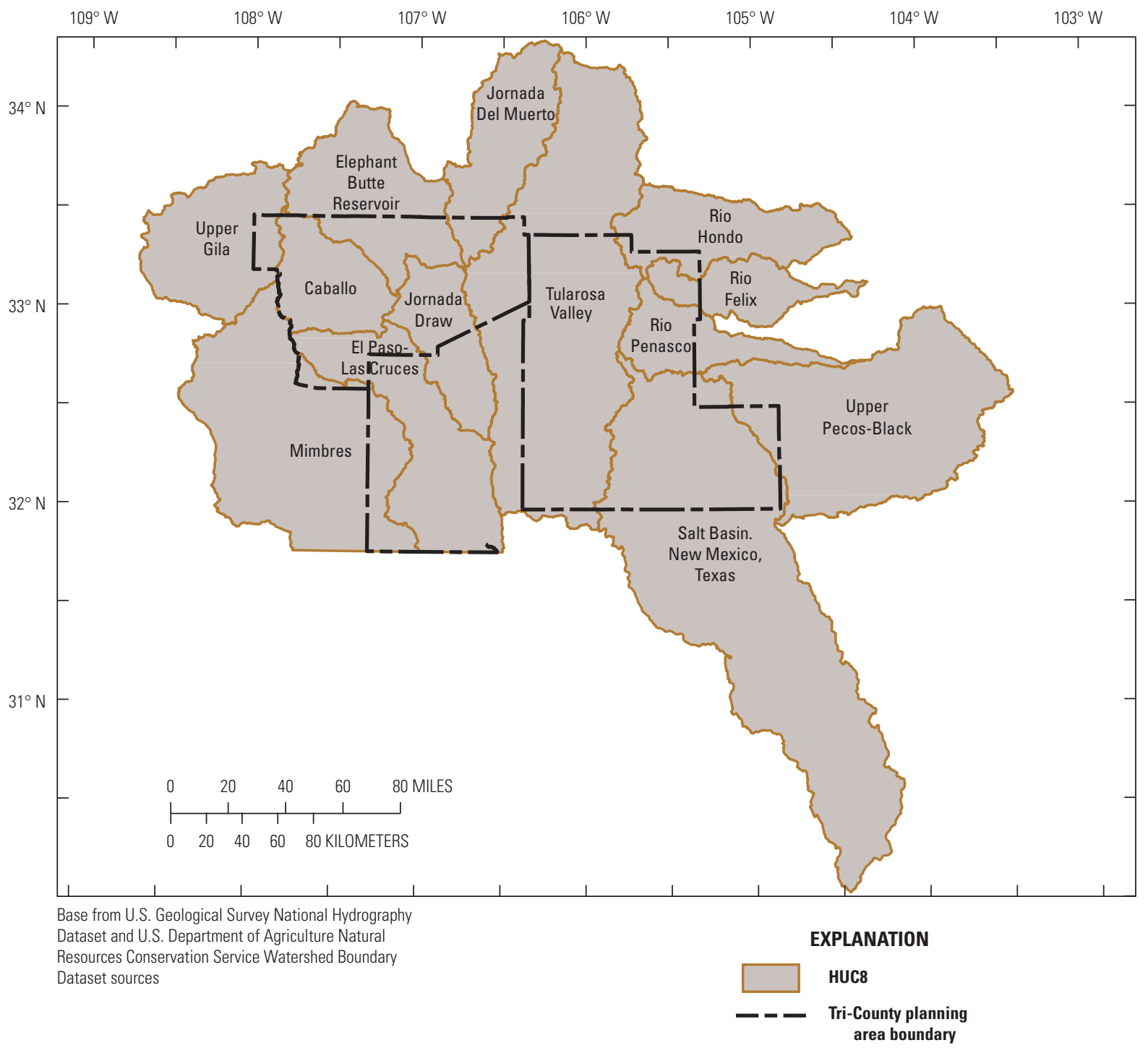

Figure 11. The Tri-County planning area and 8-digit hydrologic unit code (HUC8) watershed boundaries. 


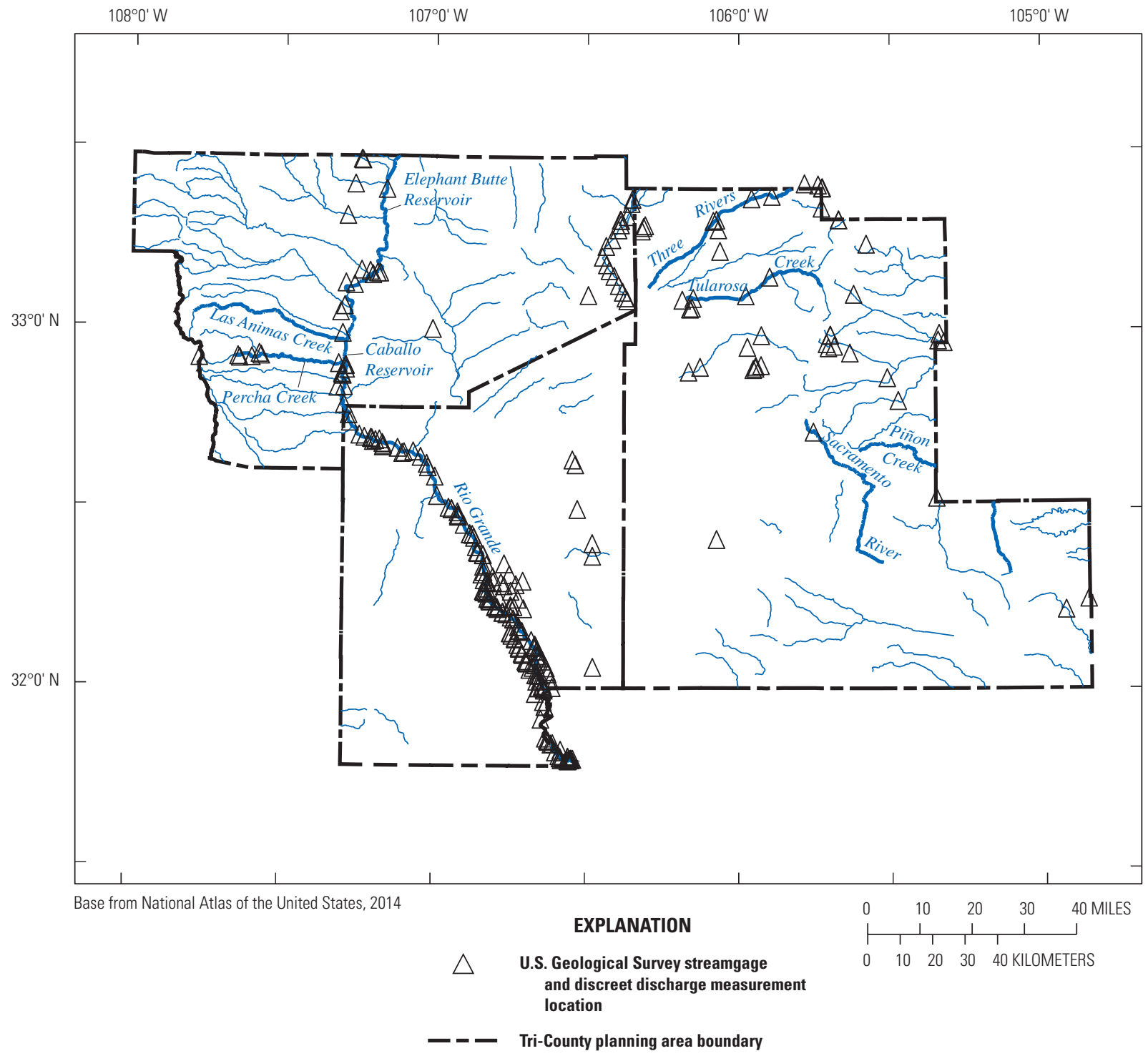

Figure 12. Locations of U.S. Geological Survey streamgages and discrete discharge measurements, Tri-County study area, New Mexico, 2015. 
Table 2. Summary statistics for continuous-record streamgages in the Tri-County planning area, New Mexico.

[USGS, U.S. Geological Survey; sNM, New Mexico; max, maximum; min, minimum; n.d., no data]

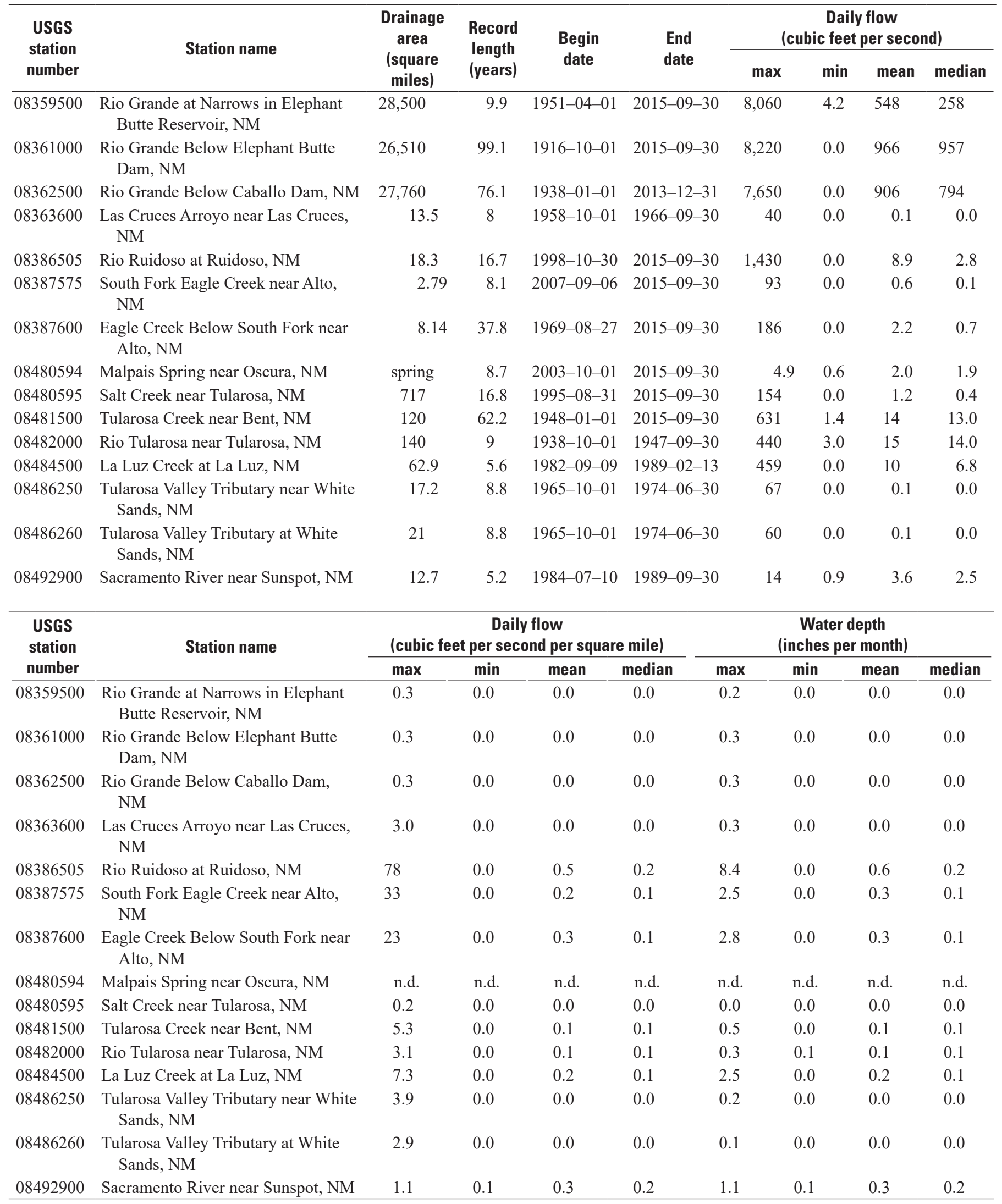




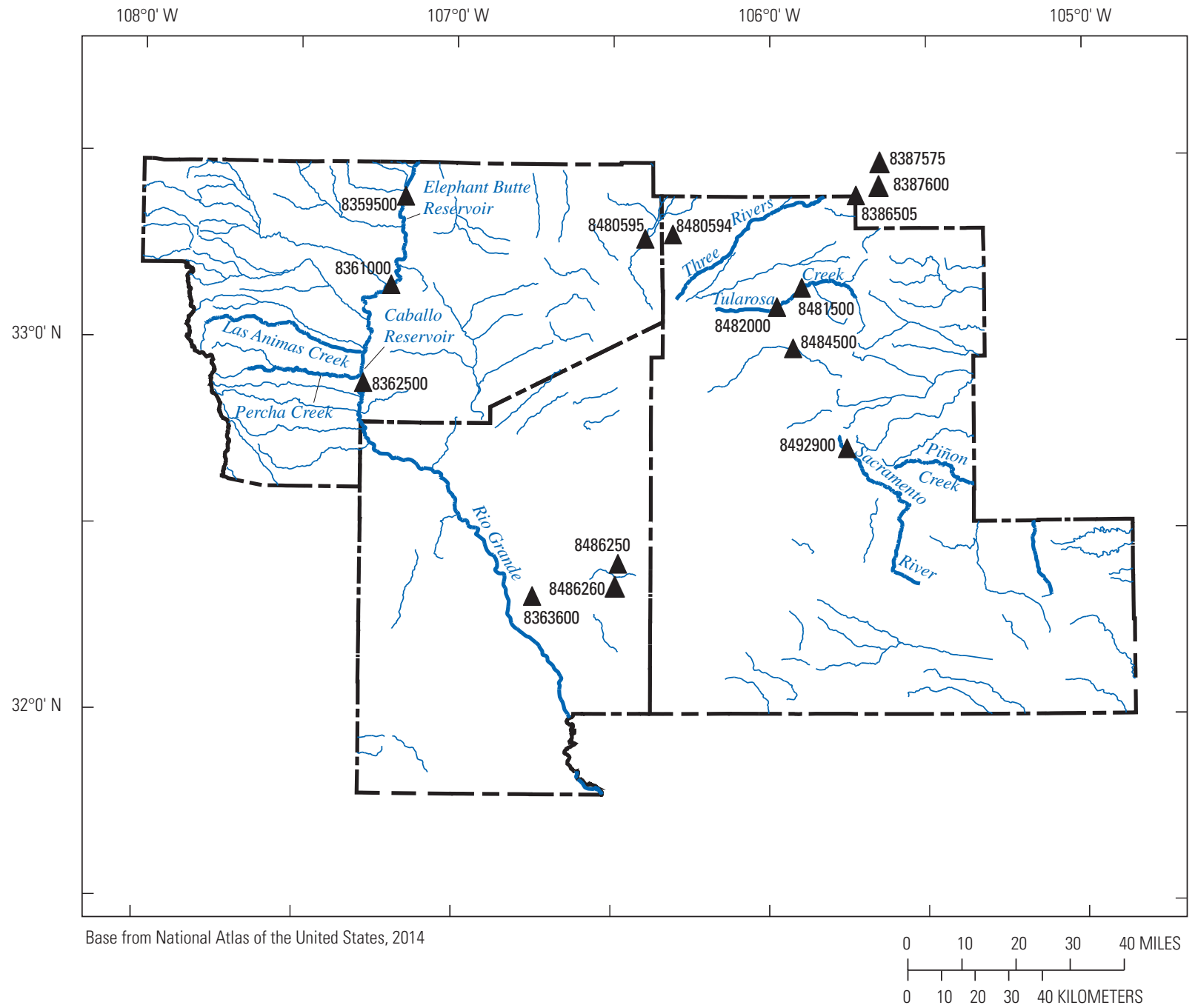

EXPLANATION

$\begin{array}{cll}\begin{array}{cll}\text { Station number } & \text { Station name } & \text { U.S. Geological Survey streamgage } \\ \text { with continuous daily values }\end{array} \\ 8359500 & \text { Rio Grande at Narrows In Elephant Butte Reservoir, NM } & \text { Tri-County planning area boundary } \\ 8361000 & \text { Rio Grande below Elephant Butte Dam, NM } & \\ 8362500 & \text { Rio Grande below Caballo Dam, NM } & \\ 8363600 & \text { Las Cruces Arr near Las Cruces, NM } & \\ 8386505 & \text { Rio Ruidoso at Ruidoso, NM } & \\ 8387575 & \text { South Fork Eagle Creek near Alto, NM } & \\ 8387600 & \text { Eagle Creek below South Fork near Alto, NM } & \\ 8480594 & \text { Malpais Spring near Oscura, NM } \\ 8480595 & \text { Salt Creek near Tularosa, NM } \\ 8481500 & \text { Tularosa Creek near Bent, NM } \\ 8482000 & \text { Rio Tularosa near Tularosa, NM } \\ 8484500 & \text { La Luz Creek at La Luz, NM } \\ 8486250 & \text { Tularosa Valley Tributary near White Sands, NM } \\ 8486260 & \text { Tularosa Valley Tributary at White Sands, NM } \\ 8492900 & \text { Sacramento River near Sunspot, NM }\end{array}$

Figure 13. Locations of U.S. Geological Survey streamgages in the Tri-County planning area, New Mexico. 


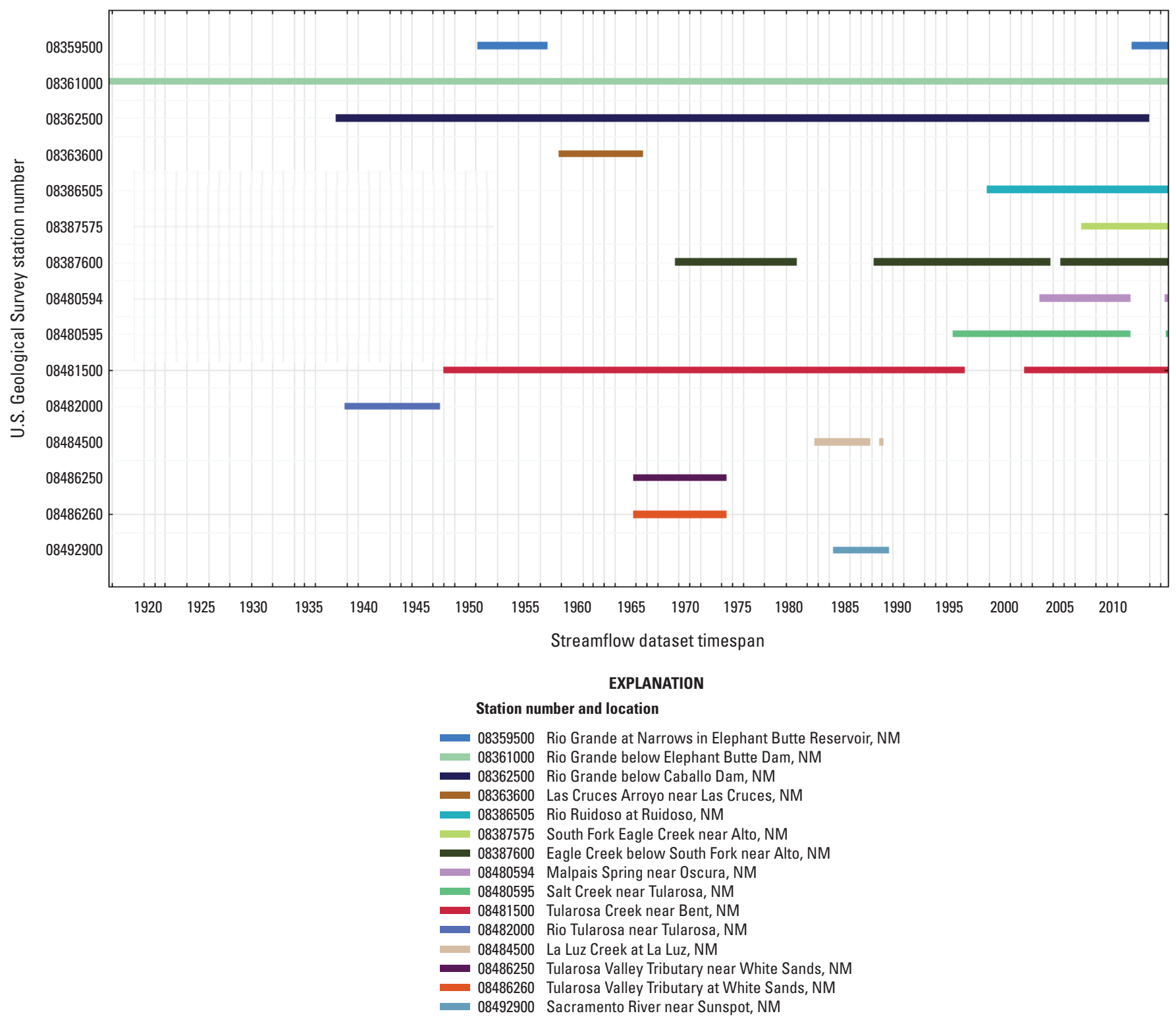

Figure 14. Periods of record for the 15 U.S. Geological Survey continuous-record streamgages in Sierra, Doña Ana, and Otero Counties, New Mexico, 1920 through September 30, 2015. 

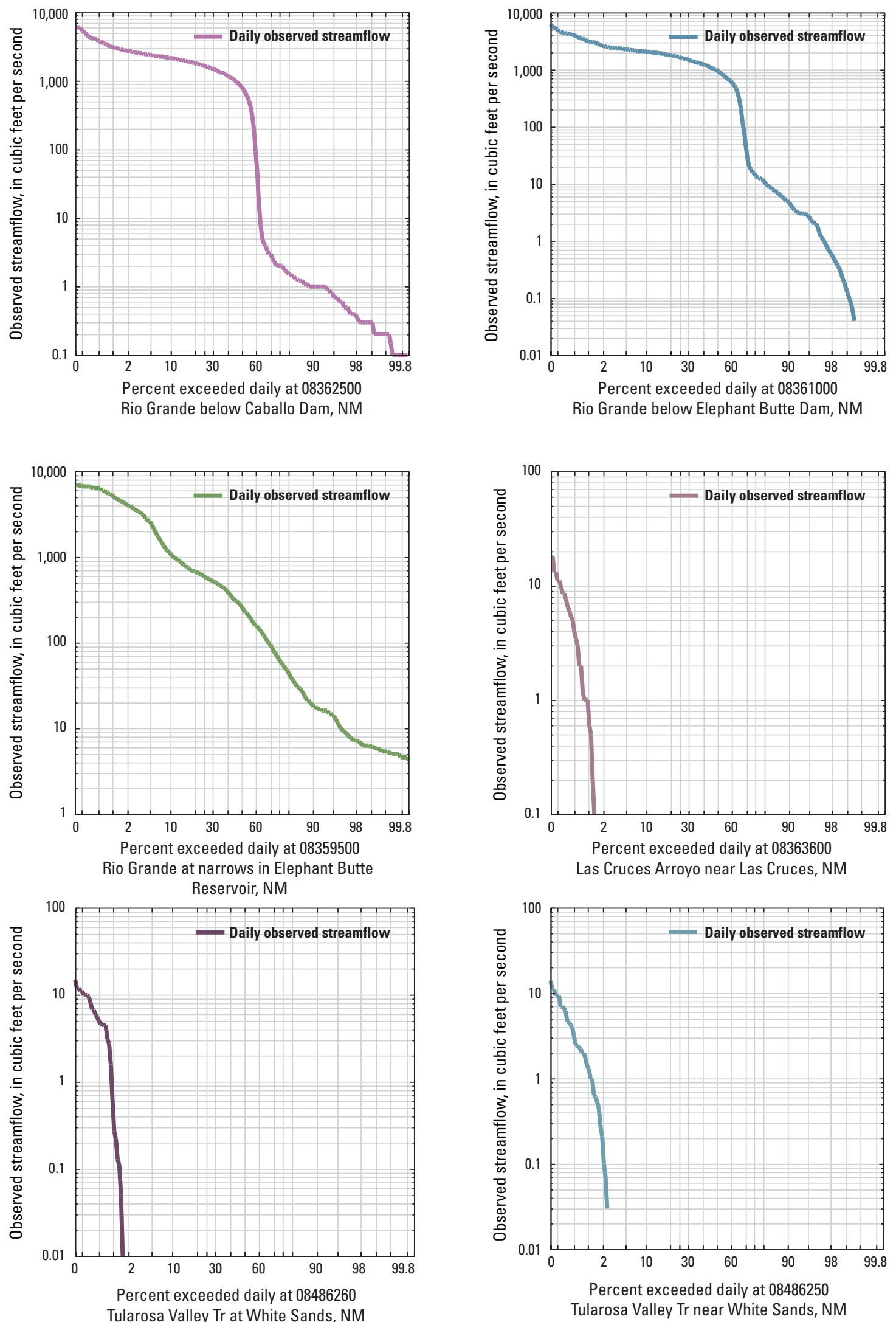

Figure 15. Discharge duration curves for 15 continuous-record streamgages in the Tri-County planning area, New Mexico. 

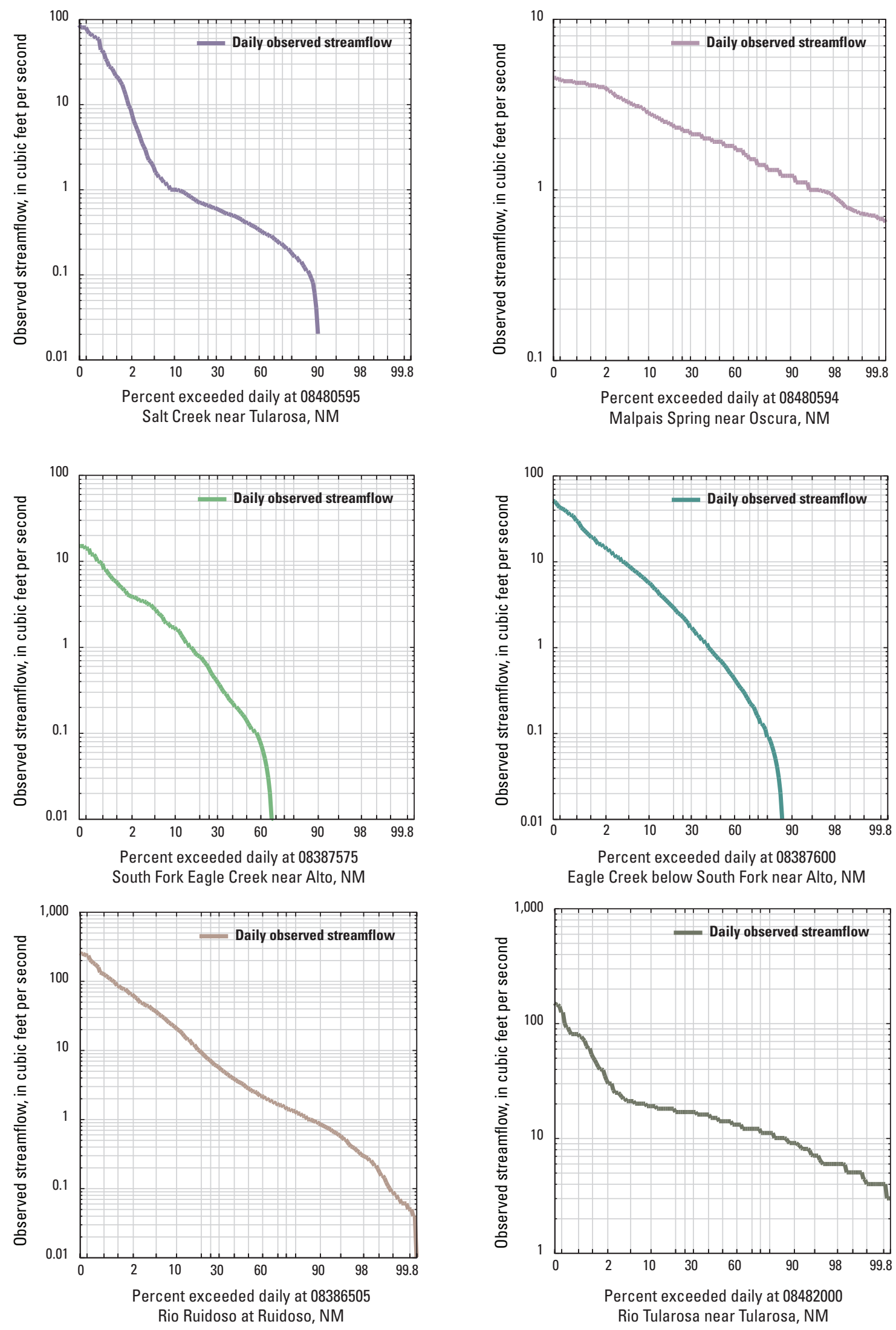

Figure 15. Discharge duration curves for 15 continuous-record streamgages in the Tri-County planning area, New Mexico.-Continued 

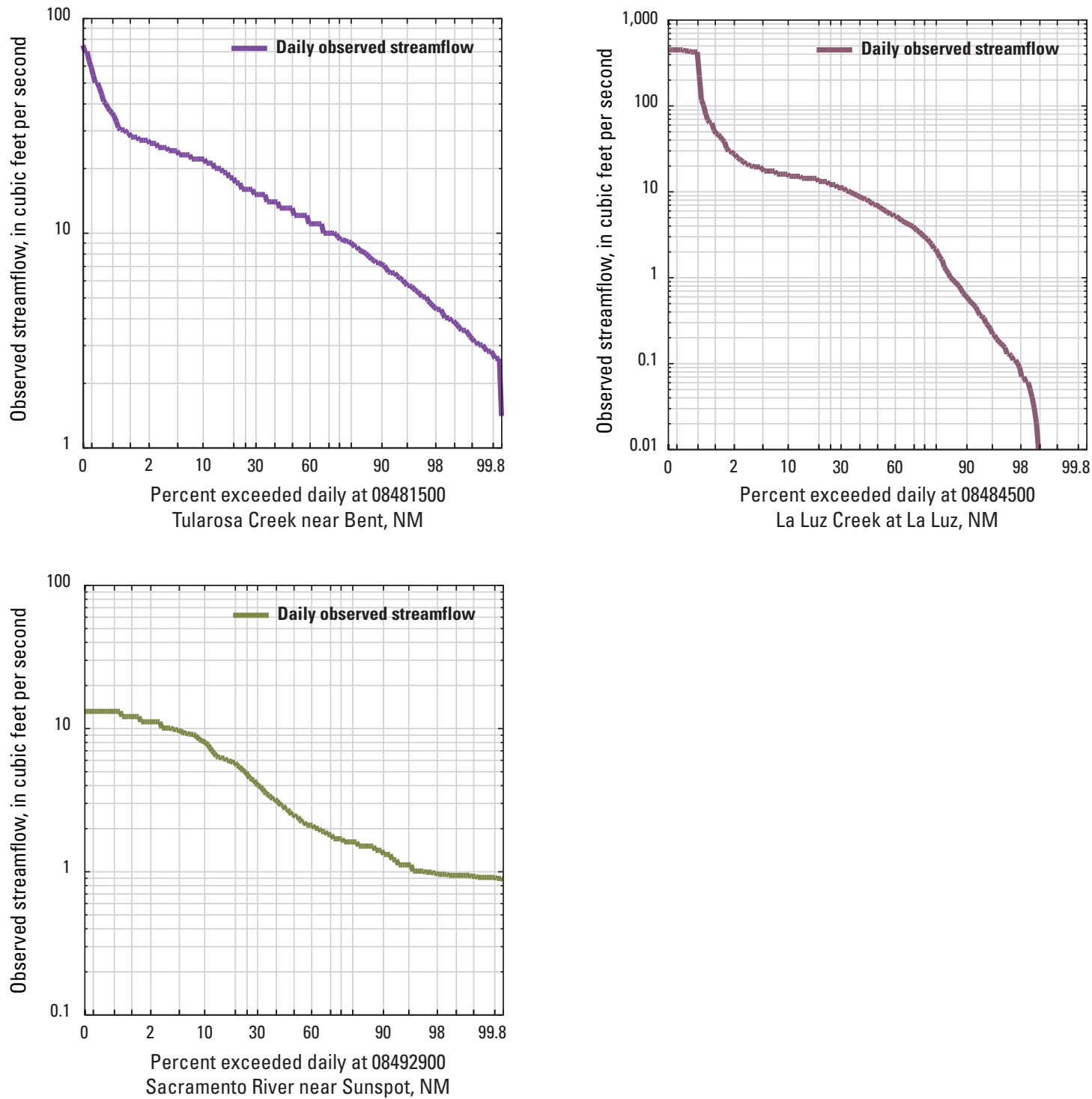

Figure 15. Discharge duration curves for 15 continuous-record streamgages in the Tri-County planning area, New Mexico.-Continued 


\section{Groundwater}

The Tri-County planning area has three major aquifer types: (1) thin alluvial-fan and river-laid unconsolidated deposits such as the Salt Basin; (2) basin fill of deep downfaulted basins such as the Tularosa Basin and the Rio Grande Valley; and (3) consolidated limestone, sandstone, and shale such as Otero Mesa (New Mexico Interstate Stream Commission and the New Mexico Office of the State Engineer, 2002).

Groundwater and surface-water systems originating in the Tri-County planning area are generally recharged by precipitation delivered as snow in highland areas such as the San Andres and Sacramento Mountains, and to a lesser degree by rainfall. Snowmelt in highland areas provides spring runoff to surface-water systems and also provides recharge to regional groundwater systems. Streamflows may also recharge groundwater systems if stream channels traverse permeable zones and if groundwater storage areas are in deficit. Groundwater may discharge naturally at springs and areas of low elevation, as a function of hydraulic characteristics and hydraulic gradient, and may also discharge to extraction wells.

For the purpose of administering water rights in New Mexico, groundwater basins are delineated and designated in a process of declaration by the Office of the State Engineer (fig. 16; New Mexico Office of the State Engineer and the New Mexico Interstate Stream Commission, 2017d). Groundwater-levels throughout the Tri-County planning area are based on data from multiple sources spanning many years and therefore are only representative of regional groundwater conditions and should not be relied upon for site-specific analysis (fig. 17). Within each of the areas of interest pertinent to this study, the important aquifers are described and representative hydrographs are shown, subject to the availability of long-term water-level data. Table 3 lists ranges and average depths to groundwater and total depths of wells in potential oil and gas development areas. (Average depth to groundwater calculations excluded data categorized as "confined" and zero-valued depth to water data; calculations were performed without respect to spatial or temporal data distribution).

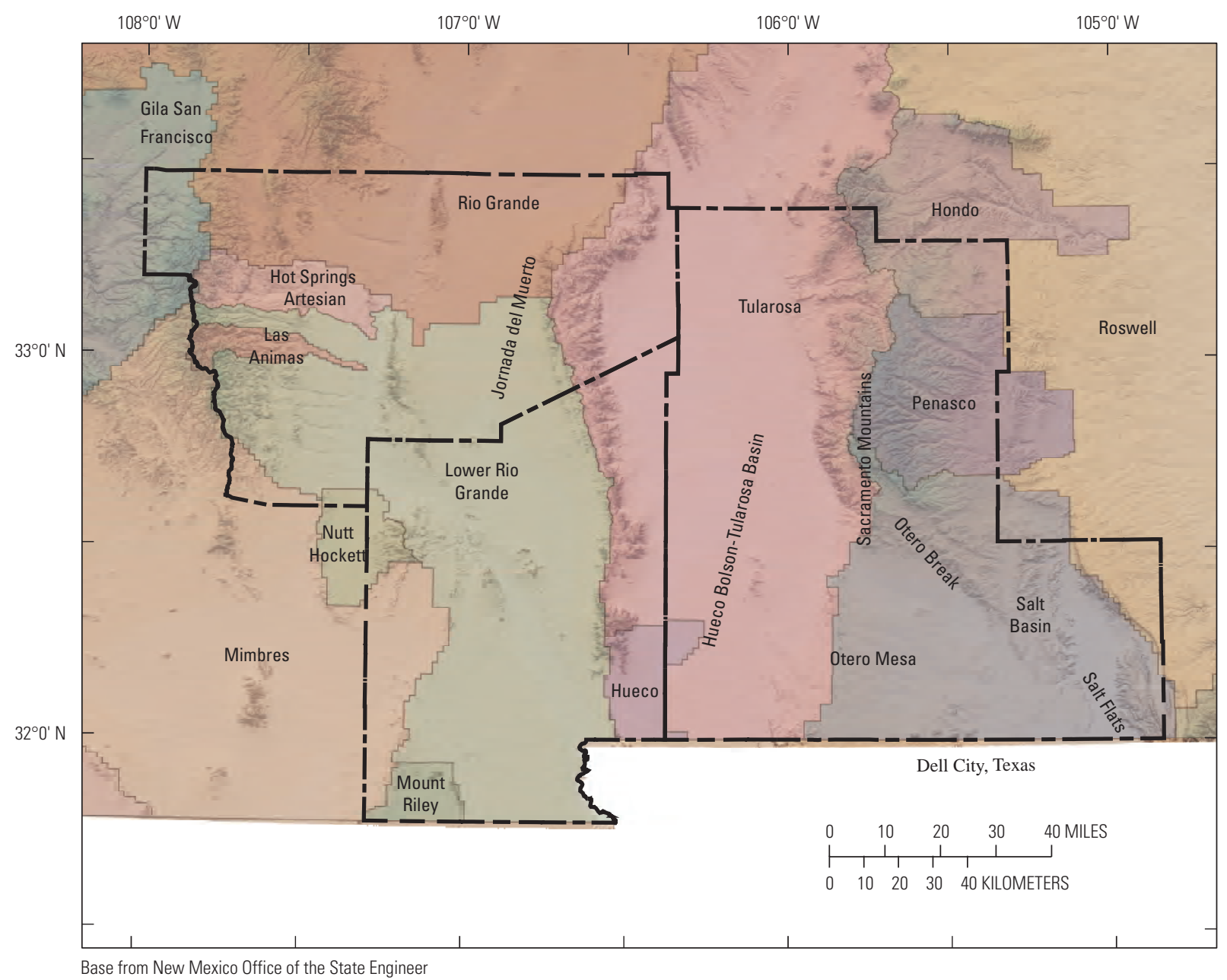

Figure 16. Groundwater basins, the Sacramento Mountains, Otero Break, and Salt Flats in the Tri-County planning area as delineated by the New Mexico Office of the State Engineer (New Mexico Office of the State Engineer and the New Mexico Interstate Stream Commission, 2017c). 


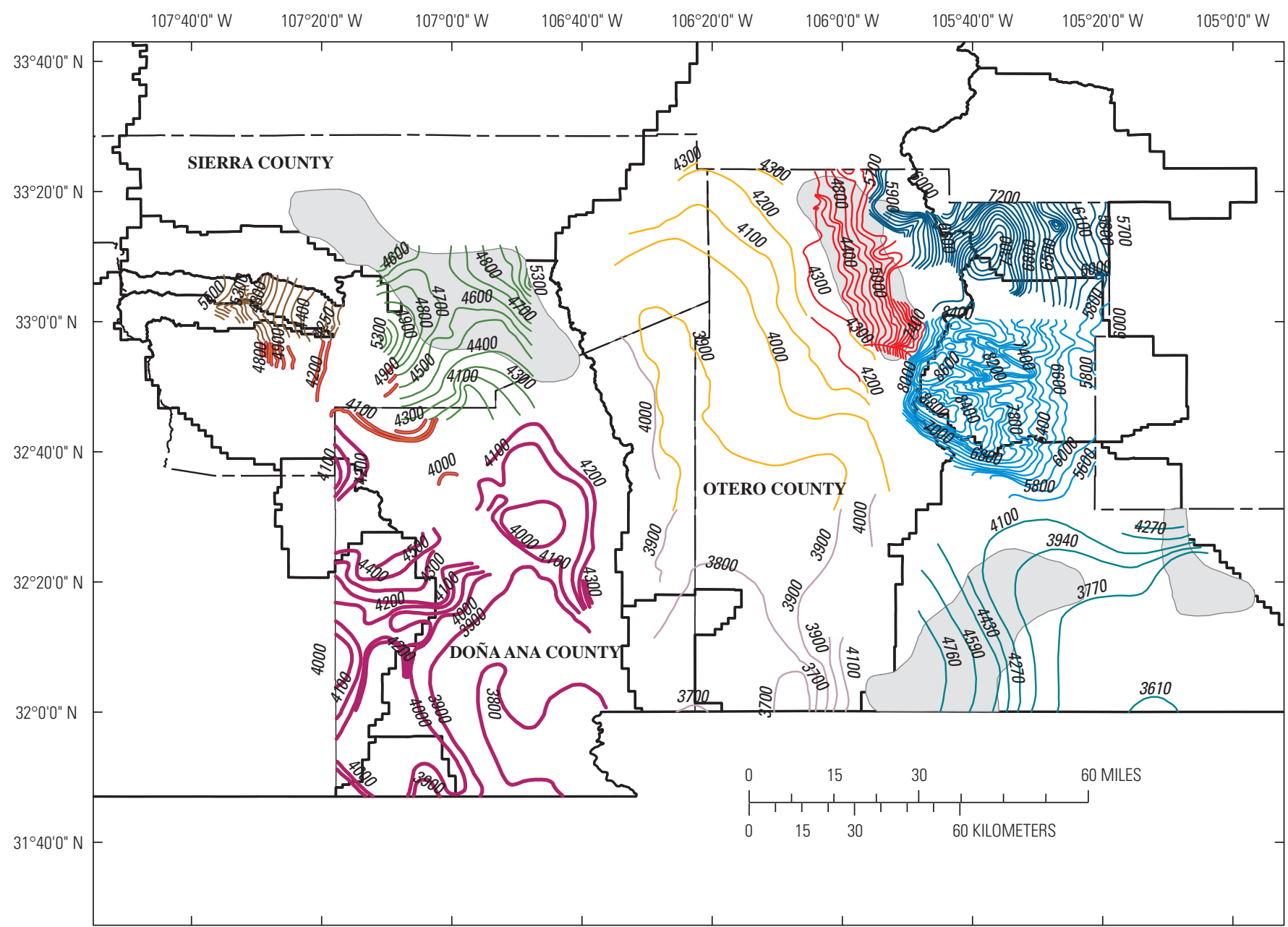

EXPLANATION

Groundwater-level contour-shows altitude of groundwater levels, in feet above North American Vertical Datum of 1988. Contour interval variable

Davie and Spiegel, 1967 Land and others, 2014

Newton and others, 2015

Sloan and Garber, 1971

Conover, 1954

Land and others, 2012

Wilson and others, 1981

Mayer and Sharp, 1998

Newton and Allen, 2014

Hibbs and others, 1997

Water level elevation, in feet

Declared groundwater basins

Areas of interest

Figure 17. General groundwater levels in the Tri-County planning area, based on available data in the area, $1967-2017$. 
Table 3. Oil, gas, and coalbed methane well potential-development estimates with groundwater level data and hydrocarbon occurrence depths related by areas in the Tri-County planning area, New Mexico.

[ft, foot; NAVD 88, North American Vertical Datum of 1988; K, Cretaceous; *, Pennsylvanian; M, Mississippian; S, Silurian; |, Paleozoic (undivided); O-G, oil and gas; CBM, coalbed methane; USGS, U.S. Geological Survey; GIS, geographic information system; ?, uncertain; O, Ordovician]

Potential development estimates for conventional oil, gas, and coalbed methane wells with associated estimates of nearby groundwater depths

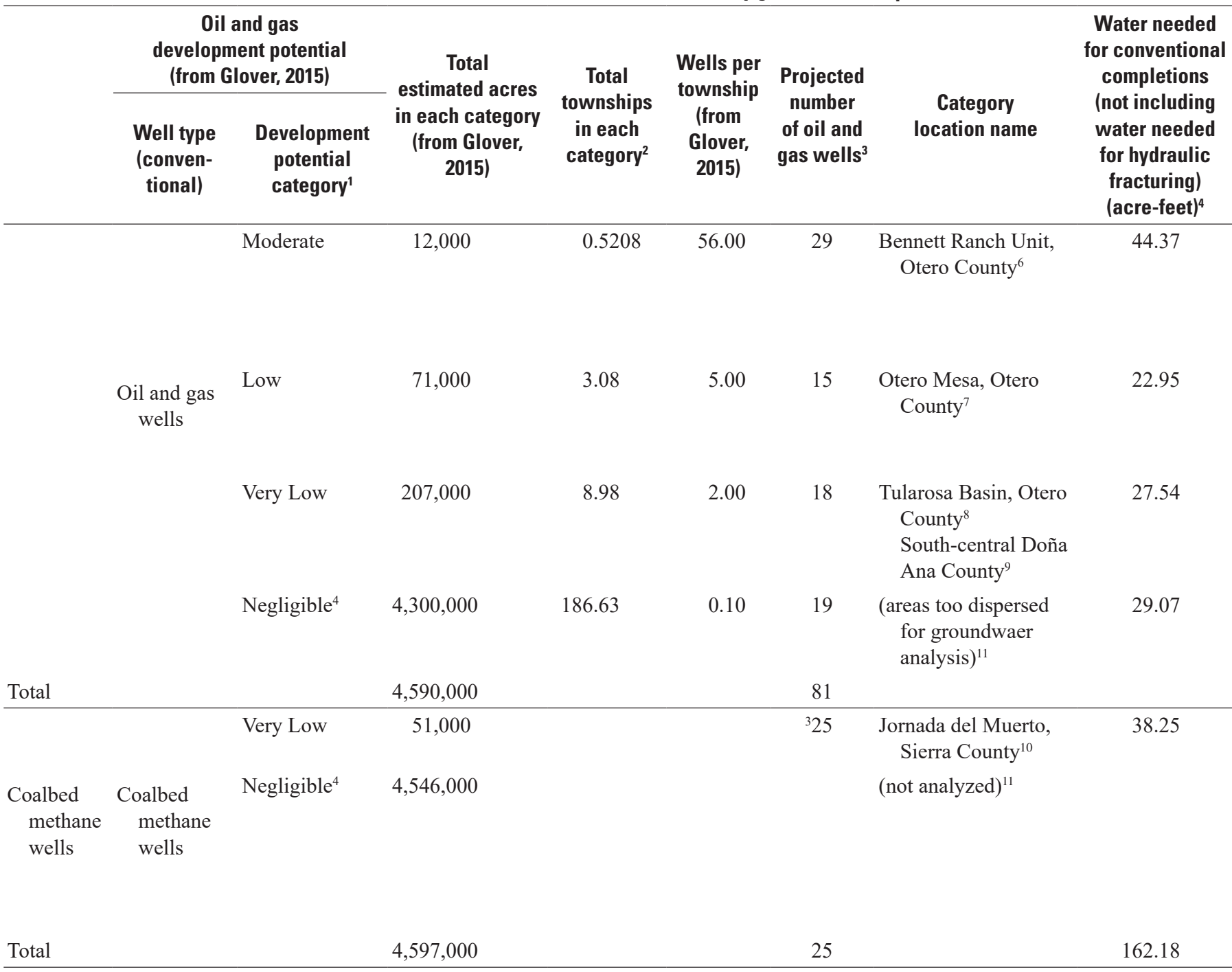

Percent difference in acreage estimates

0.152

Total (or total range)

106

162.18

${ }^{1}$ Negligible potential, as reported by Glover (2015), not assessed for coalbed-methane potential development.

${ }^{2}$ Township area calculated as total acres/(640 acres/square mile)/36 square miles.

${ }^{3}$ Wells per potential development category calculated as total townships $\times$ wells per calculated township area.

${ }^{4}$ Areas designated negligible for $\mathrm{O}-\mathrm{G}$ wells and CBM wells have essentially equivalent boundaries (difference 0.15 percent).

${ }^{5}$ Average data included all measurements taken, disregarding disparate periods of record; data rounded; range, average, and number of wells used to estimate is provided if sufficient data are available. Data from USGS Groundwater Site Inventory database synthesized in GIS.

${ }^{6}$ Bennett Ranch Unit formation of water-well completion unknown; data for one unique well in area of moderate potential development.

${ }^{7}$ Otero Mesa formation of water-well completion categorized variously as Bone Springs Limestone or unknown; dataset composed of five unique groundwater wells with unknown formations-of-completion in or within 1 mile of area of low potential development.

${ }^{8}$ Tularosa Basin formations of water-well completion categorized variously as alluvium, bolson deposits, Santa Fe Formation deposits, or uncategorized; data for 246 wells. 
Table 3. Oil, gas, and coalbed methane well potential-development estimates with groundwater level data and hydrocarbon occurrence depths related by areas in the Tri-County planning area, New Mexico.-Continued

[ft, foot; NAVD 88, North American Vertical Datum of 1988; K, Cretaceous; *, Pennsylvanian; M, Mississippian; S, Silurian; |, Paleozoic (undivided); O-G, oil and gas; CBM, coalbed methane; USGS, U.S. Geological Survey; GIS, geographic information system; ?, uncertain; O, Ordovician]

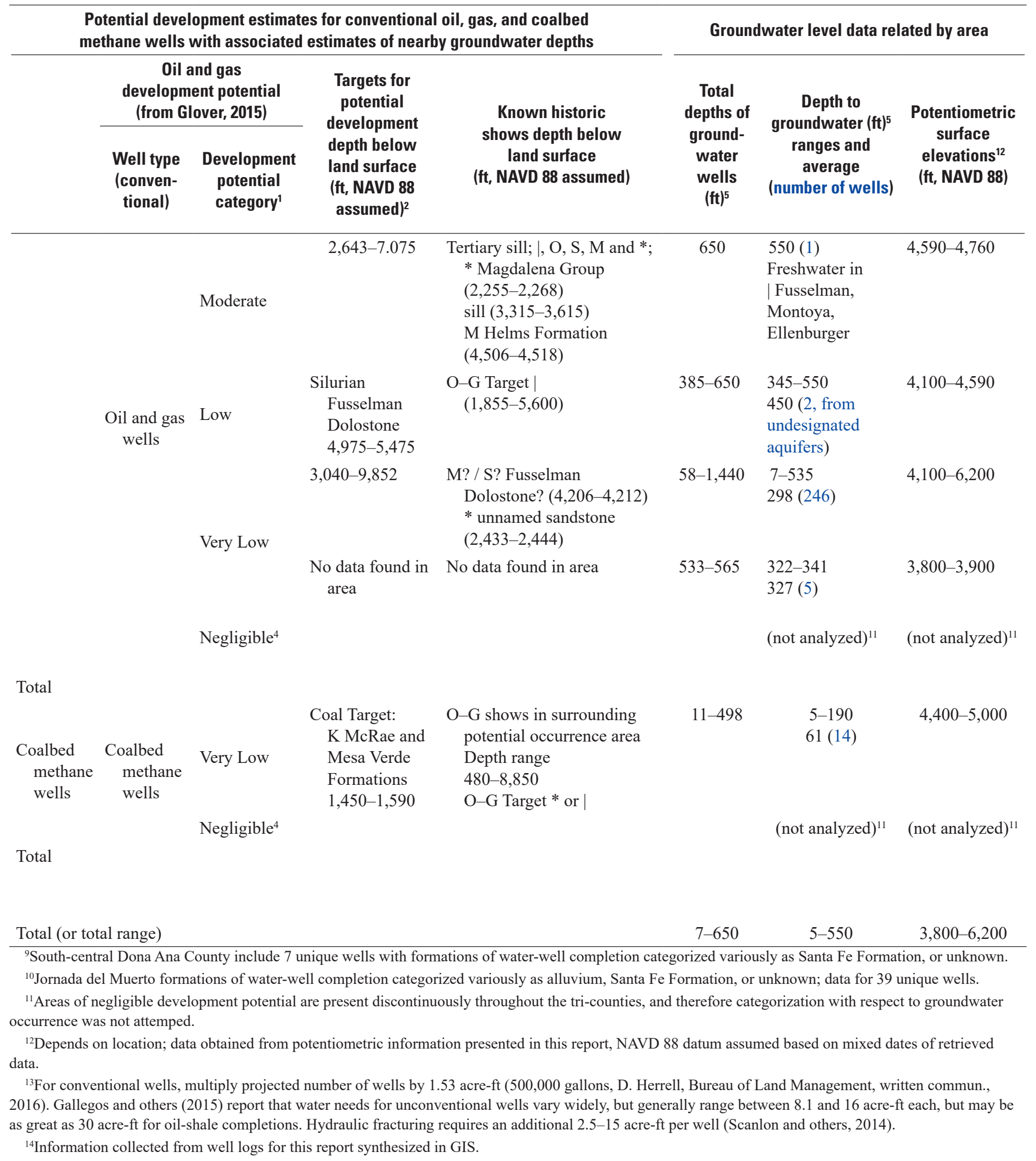




\section{Groundwater in the Jornada del Muerto}

The important aquifers in the Jornada del Muerto include shallow aquifers contained in Quaternary alluvium as well as in the Love Ranch and McRae Formations (Newton and others, 2015). Shallow alluvial groundwater may be perched; however, perched groundwater appears to recharge regional systems deeper than $200 \mathrm{ft}$ below land surface (Newton and others, 2015). The shallowest water, about $30 \mathrm{ft}$ below land surface, is found in the center of the basin, and deeper water is found to the east and south. In the southern part of the Jornada del Muerto, groundwater is generally 200 to $600 \mathrm{ft}$ below land surface (Brady and others, 1983). Groundwater on the western side of the San Andres Mountains flows southwesterly to discharge to the Rio Grande (fig. 18).

In Sierra County, groundwater-level contour maps near Las Animas Creek, which flows into the Caballo Reservoir, show a general flow from west to east (Davie and Spiegel, 1967). The contours are drawn from groundwater-levels in the Santa Fe Group. On the western and eastern sides of the Jornada del Muerto, groundwater flows towards the center of the basin (fig. 18; Newton and others, 2015). Additionally, in the northwest part of the basin, groundwater flows to the northwest, and in the south-central part of the basin, groundwater flows to the south towards the Rio Grande (fig. 18).

Within and nearby the Sierra County area of potential development, total depths of groundwater wells range from 11 to $498 \mathrm{ft}$, while depths to groundwater range from 5 to $190 \mathrm{ft}$ (table 3; USGS, 2017c).

Two groundwater wells were selected for hydrograph analysis within the Jornada del Muerto in Sierra County (fig. 19). Both wells are located in areas of high oil and gas potential. In the alluvial bolson aquifer, USGS site identifier (ID) 331002107150001 (latitude $33.1673^{\circ}$, longitude $-107.2506^{\circ}$ ) was selected because of the long period of record of measurements, spanning from 1972 to 2005 . At the second site, USGS site ID 325726106585701 (latitude $32.9568^{\circ}$, longtitude $-106.9858^{\circ}$ ), completed in the Santa Fe Group aquifer, the six measurements included in the period of record spanned from 1984 to 2014.

The alluvial bolson aquifer in the Jornada del Muerto started to show a rise in groundwater levels in the mid-1980s until around 1996. Then groundwater-levels began to decline. Overall, from 1972 to 2005, groundwater-levels have risen $10-15 \mathrm{ft}$ in this aquifer at site 331002107150001 (fig. 19).
More recently, groundwater-levels have only varied by approximately $9 \mathrm{ft}$ from 1997 to the most recent measurement in 2005.

The Santa Fe Group aquifer in the Jornada del Muerto has limited historical data available, but groundwaterlevels did decline from the mid-1980s until 2014. Overall, groundwater-levels at site 325726106585701 have declined nearly $15 \mathrm{ft}$ in this aquifer.

\section{Groundwater in the Tularosa Basin}

In the Tularosa Basin in Otero County, the most important aquifer is 3,000 to 4,000 ft of Quaternary basin-fill deposits. For 246 wells, depth to groundwater ranges from 7 to $535 \mathrm{ft}$ below land surface, with an average of $298 \mathrm{ft}$ below land surface (table 3; USGS, 2017c). In the northeastern Tularosa Basin, surrounding the RFDS for oil and gas area of interest, groundwater flows from east to west, from the Sacramento Mountains towards the center of the basin (fig. 20; Land and others, 2014).

In the Tularosa Basin, the alluvium contains shallow and deep groundwater. Two groundwater wells were selected for analysis within the Tularosa Basin in Otero County (fig. 21). USGS site ID 330545106004001 (latitude $33.0959^{\circ}$, longitude $-106.0117^{\circ}$ ) is a well completed within the alluvial bolson aquifer and was selected because there is a dense water-level dataset with a 20-year range (1952-72). The second selected well within the Tularosa Basin, USGS site ID 325747105531901 (latitude $32.9619^{\circ}$, longitude $-105.8881^{\circ}$ ), is completed within the aquifer unit categorized in the USGS NWIS database (USGS, 2017c) under the general category Pediment, Terrace, and Other Deposits of Gravel, Sand and Caliche. Historical data are limited to two measurements, one each from 1994 and 2013.

Depth to groundwater for eight wells in the alluvial bolson aquifer ranges from about 110 to $175 \mathrm{ft}$ below land surface; total depths of wells range from 150 to $265 \mathrm{ft}$ (USGS, 2017c). The alluvial bolson aquifer has displayed a slight decrease in groundwater-levels from 1970 to the most recent depth-to-groundwater measurement, made in 1972 (fig. 21). Current groundwater-level data are needed in this aquifer. Between the two measurements available at site 325747105531901 in the Pediment, Terrace, and Other Deposits of Gravel, Sand and Caliche aquifer, the depth to groundwater has increased more than $7 \mathrm{ft}$. 


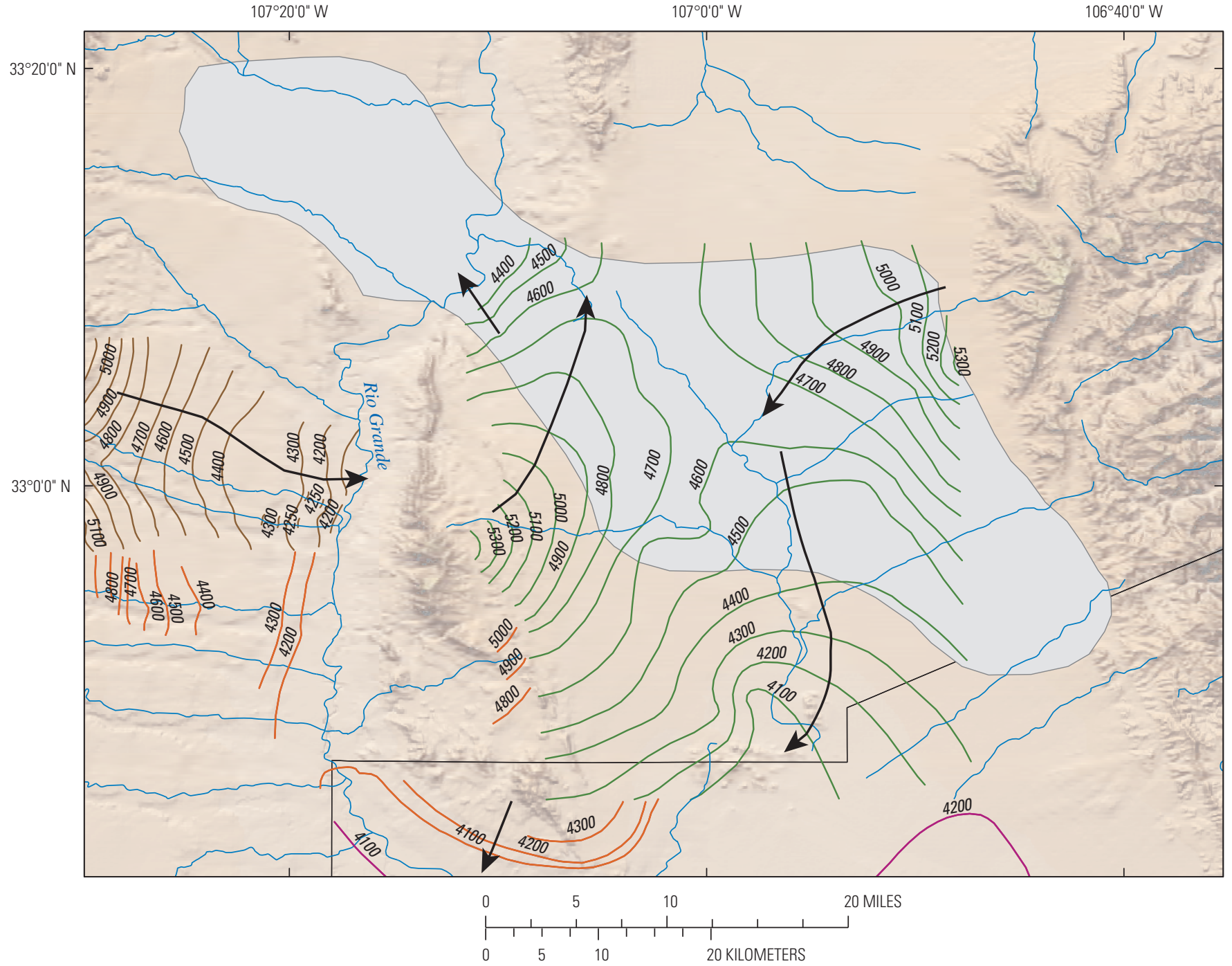

EXPLANATION

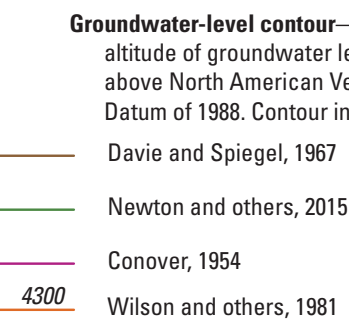

Figure 18. General groundwater levels and general flow paths in the Jornada del Muerto area, New Mexico. 

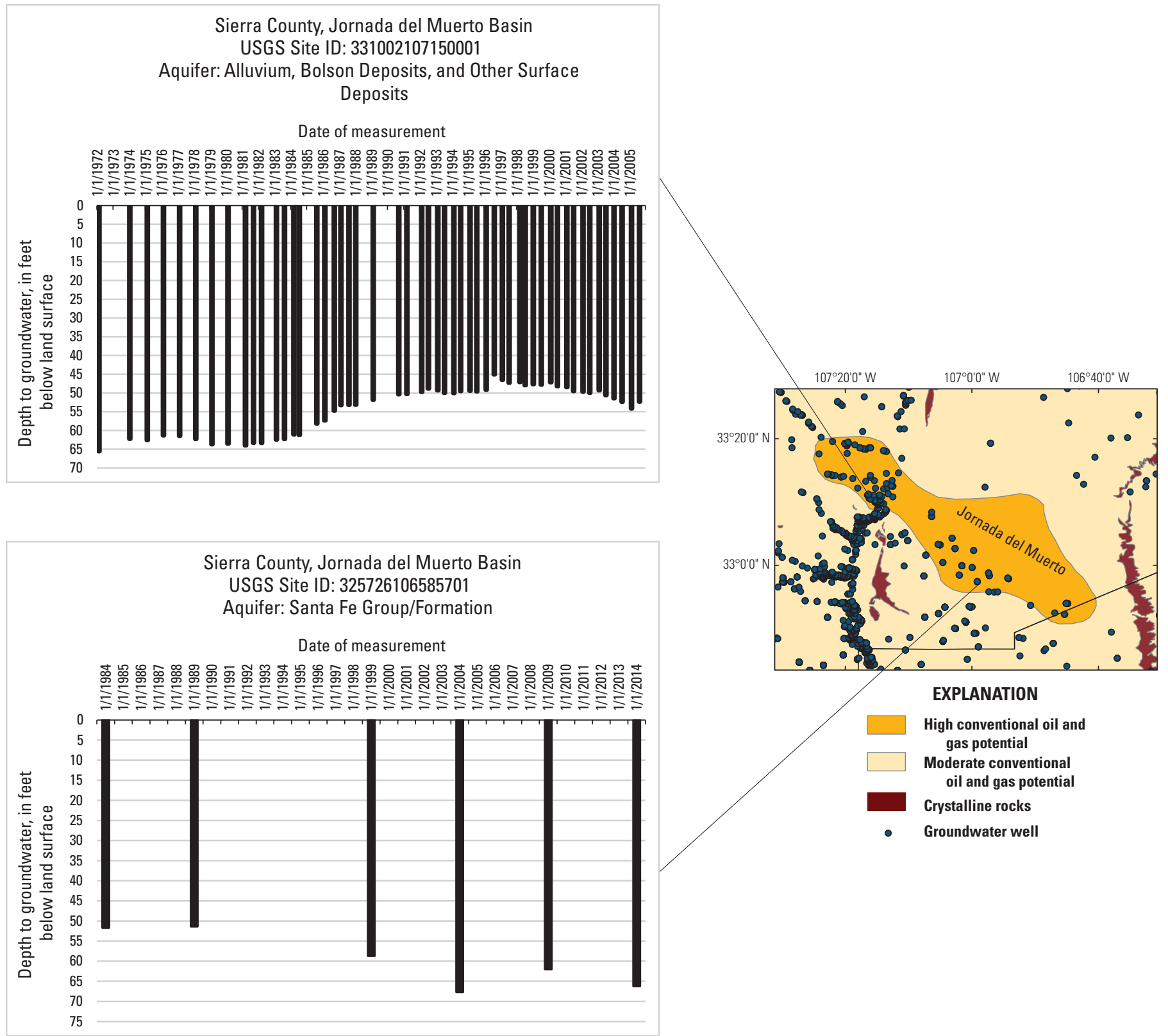

Figure 19. Depth to water in two groundwater wells in the Jornada del Muerto, Sierra County, New Mexico. 


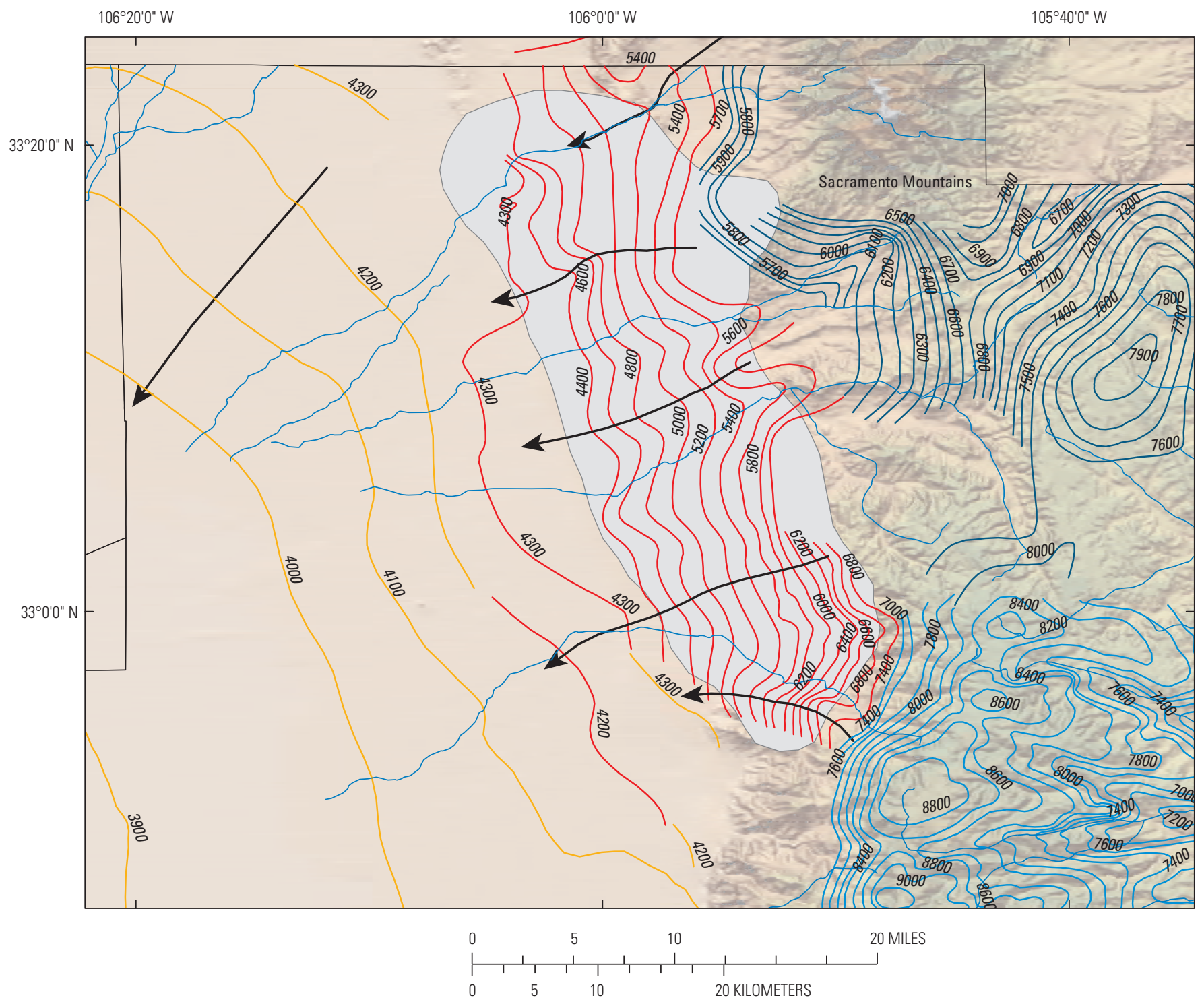

EXPLANATION

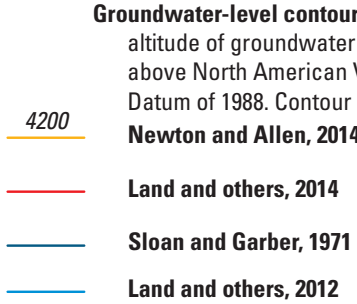

Figure 20. General groundwater levels and general flow paths in the Tularosa Basin area, New Mexico. 


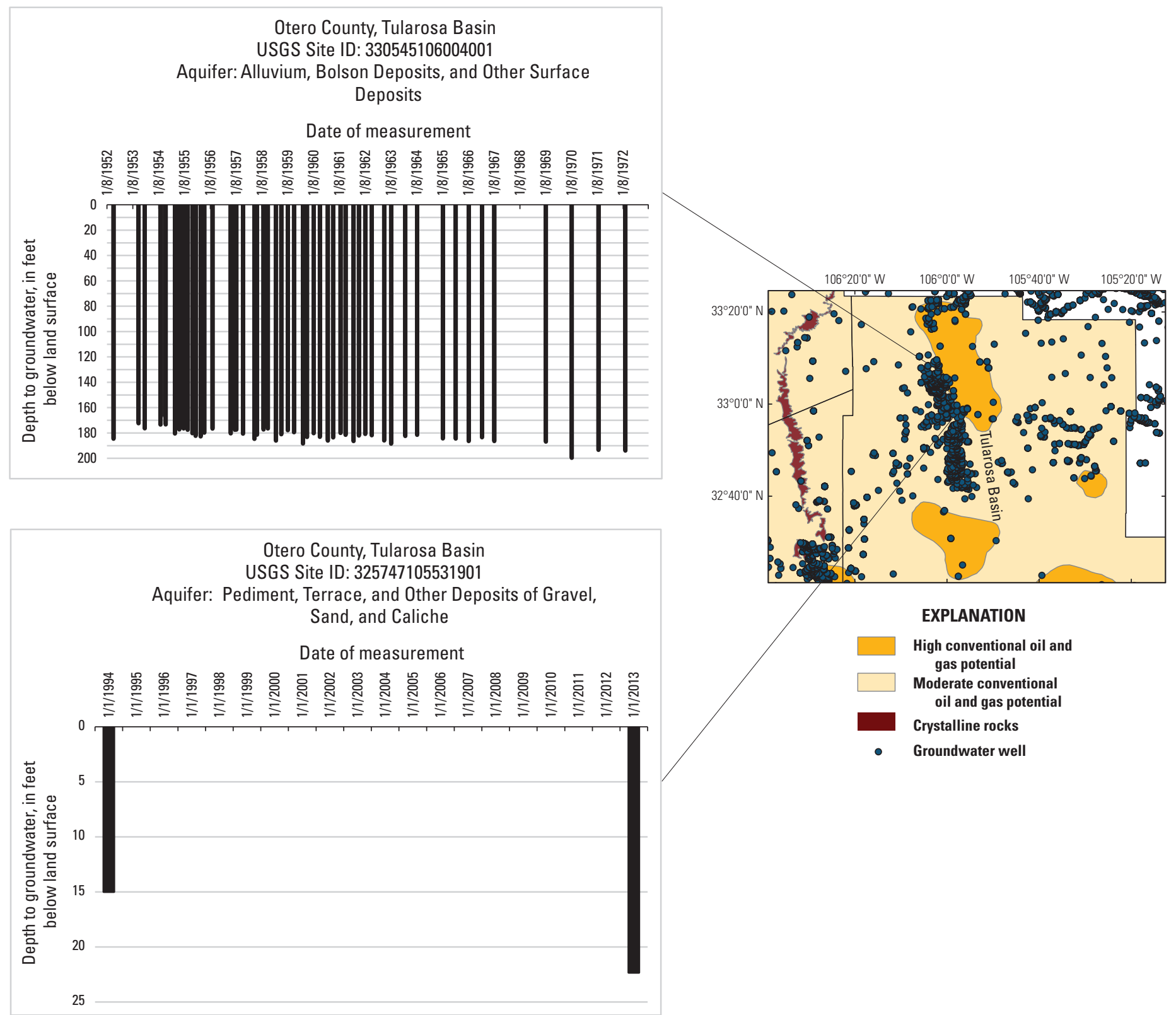

Figure 21. Depths to water in two groundwater wells in the Tularosa Basin, Otero County, New Mexico. 


\section{Groundwater in the Salt Basin}

In the Salt Basin, groundwater is found in the carbonate aquifers of the San Andres Limestone and Yeso Formation (Pray, 1961; Wasiolek, 1991; Luna, 2005; Sigstedt and others, 2016) and the sandstone aquifer of the Abo Formation (Luna, 2005). The Salt Basin is an arid hydrologically closed basin (Sigstedt and others, 2016) with carbonate bedrock overlain by alluvial fill as thick as $2,500 \mathrm{ft}$ (Mayer and Sharp, 1998). The alluvial fill is overlain by evaporite deposits composed primarily of gypsum (Mayer and Sharp, 1998). Recharge quantities to the Salt Basin are estimated to be between 15,000 to 100,000 acre-feet per year (acre-ft/yr; Sigstedt and others, 2016). This range is broad, likely because of variable precipitation and flow paths in the basin. Recharge to the Salt Basin comes from the Sacramento Mountains to the north and a south-southeast-trending high-permeability zone that allows recharge to reach the Salt Basin (Mayer and Sharp, 1998; Sigstedt and others, 2016). Additionally, ephemeral streams such as Piñon Creek (fig. 12) provide some recharge during high-intensity storm events (Sigstedt and others, 2016). The most significant fracture system, Otero Break, trends from the Sacramento River to Dell City, Texas (figs. 16 and 22; Mayer, 1995. Regional groundwater in the Dell City area flows east from the Cornudas Mountains and southeast from the Sacramento Mountains through the Otero Break (figs. 7 and 22; Sharp and others, 1993). Recharge in the southern Salt Basin and Dell City area appears to come from surfacewater infiltration through fractures underlying streambeds and arroyos (Sharp and others, 1993). Discharge in the Dell City area is predominantly from groundwater withdrawals for irrigation (Huff and Chace, 2006).

Depths to water have been measured in the Salt Basin and Otero Mesa of New Mexico and Texas from Quaternary alluvium, alluvium bolson deposits, the Yeso Formation, San Andres Limestone, Bone Spring Limestone, and Bone Spring and Victoria Limestones (fig. 23). Three wells were selected from three different aquifers in the Salt Basin. USGS site ID 320138105063101 (latitude $32.0236^{\circ}$, longitude $-105.1148^{\circ}$ ) in the Bone Spring Limestone aquifer has a large amount of historical data from 1956 to 2013. In the alluvial bolson aquifer, USGS site ID 320629105045401 (latitude $32.1082^{\circ}$, longitude $-105.0822^{\circ}$ ) has data from 1956 to 199 , although there is a data gap between 1980 and 1995. USGS site ID 320627105045701 (latitude $32.1076^{\circ}$, longitude $-105.0830^{\circ}$ ) is in the San Andres Limestone aquifer, but has only three historical water-level measurements, one each from 1995, 2000 , and 2005.

Groundwater-level data are abundant for the Bone Spring Limestone aquifer in the Salt Basin just east of the Otero Mesa (fig. 23). Groundwater levels at site 320138105063101 are available for the period 1956-2013. Large fluctuations from year to year are seen with pumping statuses noted for measurements in the USGS NWIS database (USGS, 2017c), but generally a steady decline in groundwater-levels is observed. No data exist for the period 2006-2011, but groundwater levels are similar for 2005 and 2013.

In the alluvial bolson aquifer in the Salt Basin, site 320629105045401 shows extensive water-level variations. In the late 1950s, groundwater-levels steadily increased until 1960. From 1960 until 1974, groundwater levels were measured at irregular intervals, but seem to generally decline. From 1975 to 1999, data are scarce but show variations of nearly $5 \mathrm{ft}$ in groundwater levels. Current groundwater-level data are needed for this aquifer.

Three groundwater-level measurements are available for site 320627105045701 in the San Andres Limestone aquifer in the Salt Basin (fig. 23). The three measurements (one each from 1995, 2000, and 2005) show little difference from each other, but overall the groundwater-level declined more than 1 $\mathrm{ft}$ during 1995-2005.

Only four depth-to-groundwater measurements are available from Otero Mesa (and of those, only two coincide with the RFDS-mapped conventional oil and gas occurrence potential, fig. 2). Groundwater levels at sites 320220105415501, 320622105361101, 32154510538101, and 321756105262901 were all measured once, during 1957 (fig. 23). The depth-to-water measurements at that time ranged from 350 to $800 \mathrm{ft}$ below land surface. The aquifersof-completion for these wells are not designated in the USGS database. 

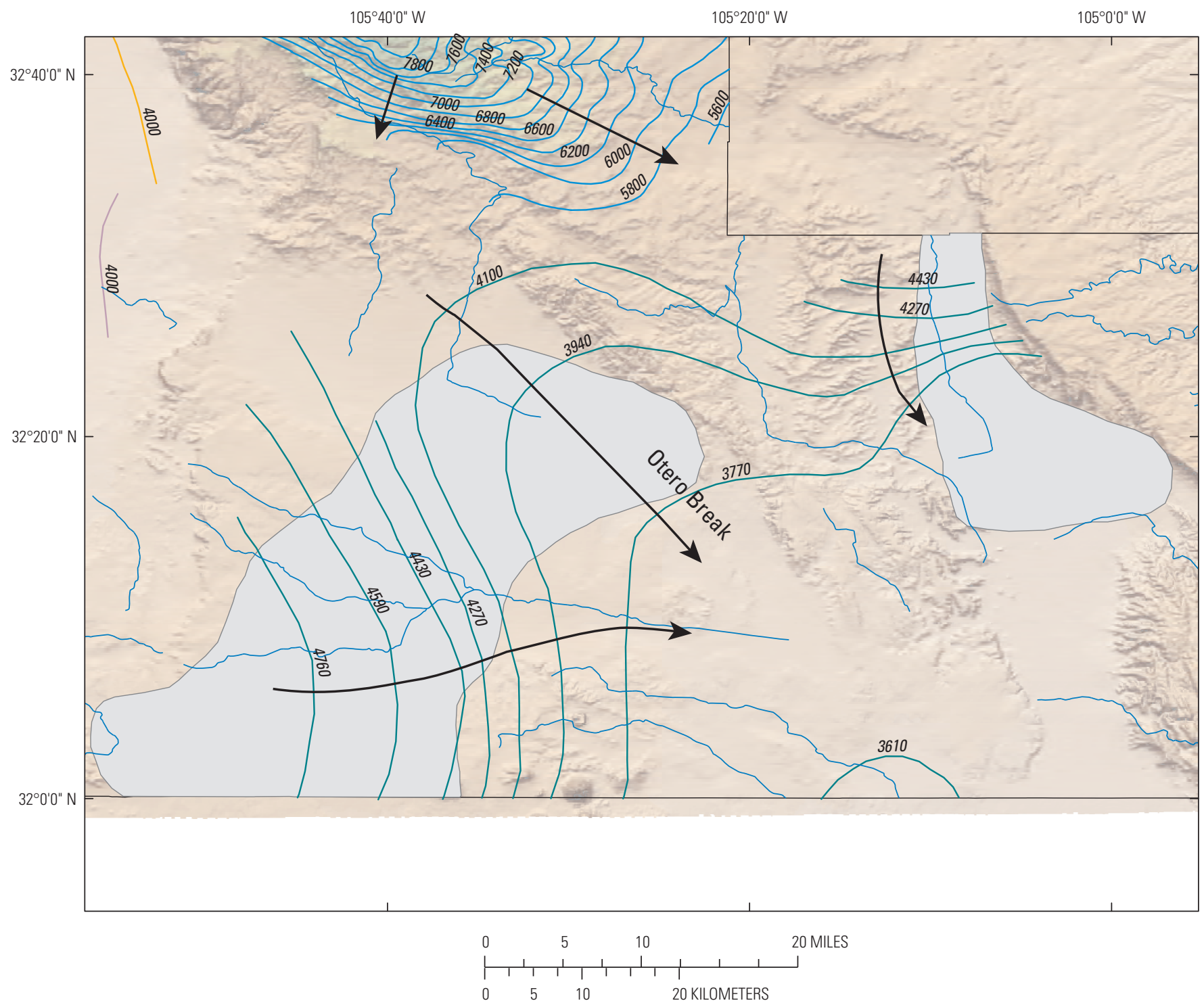

EXPLANATION

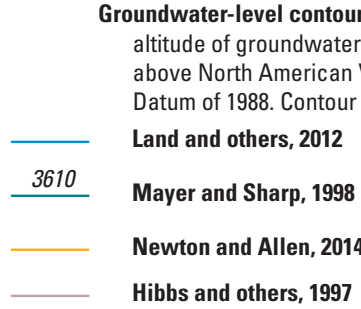

Figure 22. General groundwater levels and general flow paths in the Otero Mesa and Salt Basin areas, New Mexico. 


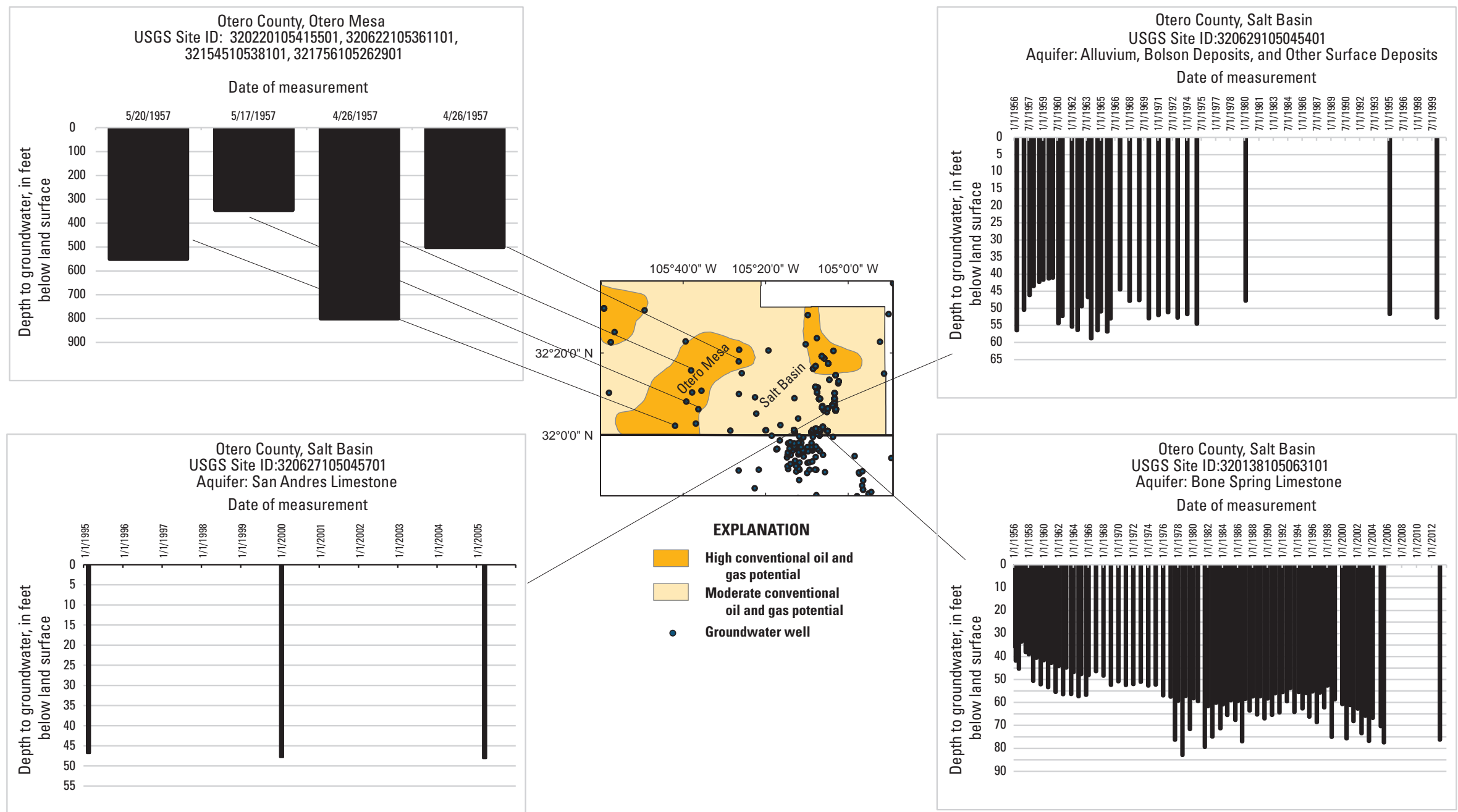

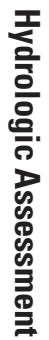

Figure 23. Depths to water in groundwater wells in the Otero Mesa and Salt Basin areas, New Mexico. 


\section{Water Quality}

In the Tri-County planning area, oil and gas development has the potential to affect the quality of water in the region needed for drinking water, irrigation, and livestock. In this area, as in much of the southwestern United States, total dissolved solids, arsenic, uranium, nitrate, chloride, sulfate, and sodium are the main water-quality concerns (Gurdak and others, 2009; Thiros and others, 2014).

Total dissolved solids (TDS) are the measure of the inorganic and organic ion content after filtration of a water sample. Major ions such as silica, bicarbonate, calcium, sodium, potassium, magnesium, chloride, and sulfate contribute to TDS concentrations and contribute to the salinity of water (Anning and Flynn, 2014). The U.S. Environmental Protection Agency (EPA) lists TDS on their national secondary drinking water regulations, which are non-enforceable guidelines for constituents in water that may cause cosmetic or aesthetic effects in public supply drinking water (EPA, 2017). The drinking water standard for TDS is $500 \mathrm{mg} / \mathrm{L}$, while other sources list a TDS of as much as $1,000 \mathrm{mg} / \mathrm{L}$ as acceptable for drinking water (Watson and others, 2003; EPA, 2017).

TDS in surface water can increase from surface weathering processes, evaporation, or infiltration of higher TDS groundwater. For streams within the Tri-County planning area, the Rio Grande has relatively low TDS (as much as $3,000 \mathrm{mg} / \mathrm{L}$ ), but the surface water in the Tularosa Basin generally has TDS greater than $35,000 \mathrm{mg} / \mathrm{L}$ (fig. 24; USGS 2017c). TDS in groundwater occurs from the interaction of water with minerals, such as carbonate rocks, or salt deposits, such as gypsum, that are in the aquifer material (Anning and Flynn, 2014). Elevated TDS in groundwater could also come from contaminated recharge or upwelling of saltier water from depth or soil enriched in salt through evapotranspiration. The TDS of groundwater across the entire Tri-County planning area ranges from freshwater (TDS less than $1,000 \mathrm{mg} / \mathrm{L}$ ) to brine (TDS greater than $35,000 \mathrm{mg} / \mathrm{L}$ ) (fig. 25 ; table 4); the likely cause of some groundwater samples being characterized as brine is the extent of carbonate and gypsum deposits in the Tri-County planning area.

In the Jornada del Muerto, groundwater ranges from fresh to slightly brackish (100 to 3,000 mg/L TDS; fig. 25; table 4; Newton and others, 2015). Deeper waters generally have higher TDS concentrations.

In the Tularosa Basin, groundwater is predominantly brackish $(>1,000 \mathrm{mg} / \mathrm{L}$ TDS) with a portion of the far western Tularosa Basin in the brine range $(>35,000 \mathrm{mg} / \mathrm{L}$ TDS) especially in the center of the basin (fig. 25; McLean, 1970; Mamer and others, 2014). A small portion, less than 0.2 percent, of the groundwater is considered freshwater, and is located in alluvial fan deposits on the western and eastern slopes of the basin (Orr and Myers, 1986; Mamer and others, 2014). TDS concentrations increase towards the center of the basin and also at depth compared to the TDS of groundwater on the western and eastern slopes of the basin (Mamer and others, 2014).

In the Otero Mesa and Salt Basin area, TDS concentrations in groundwater are in the freshwater to brackish range depending upon location (Mayer, 1995; Luna, 2005). Groundwater flows from the Sacramento Mountains southeast towards saline playas located east of Dell City, Texas (Sigstedt and others, 2016). Along the Otero Break, the water is fresh but is brackish towards the discharge area near Dell City, Texas (figs. 22 and 25). The highest TDS concentrations reported, but not plotted, in the Salt Basin exceed 300,000 mg/L in the Salt Flats plains where discharge and evapotranspiration are high (Boyd, 1982). Published estimates of water quantity and quality from the New Mexico portion of the Salt Basin indicate that 57 million acre-feet (acre-ft) of groundwater is stored, 30 million acre- $\mathrm{ft}$ have TDS concentrations of less than $1,000 \mathrm{mg} / \mathrm{L}$, and as much as 25.5 million acre-ft have TDS concentrations between 1,000 and 3,000 mg/L (Livingston Associates, P.C., and John Shomaker and Associates, Inc., 2002). 


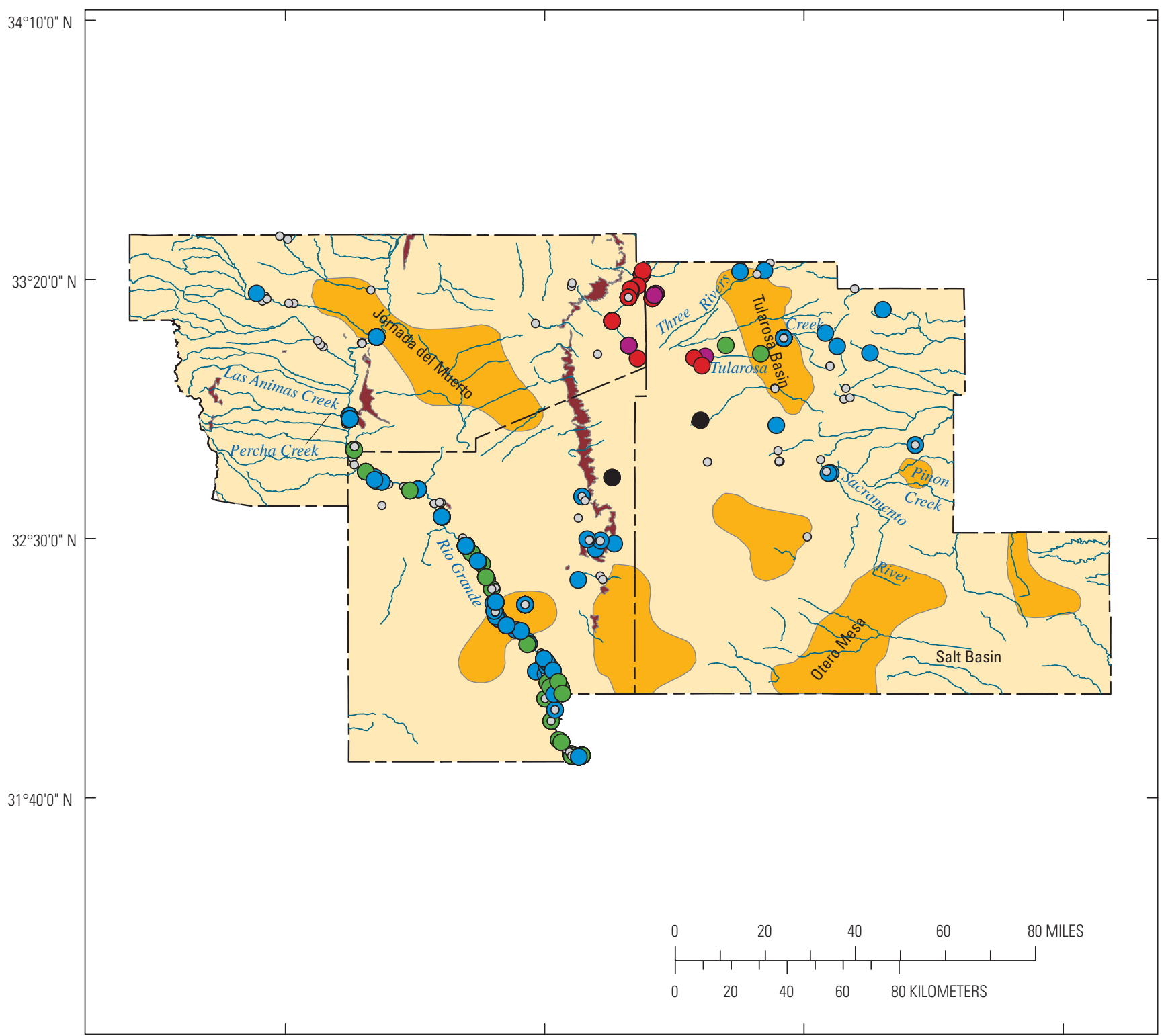

Base map from Bureau of Land Management, 2017

EXPLANATION

\begin{tabular}{|c|c|}
\hline High conventional oil & Total dissolved solids, in milligrams per liter \\
\hline anda gas potenitial & Not measured or less than 10 \\
\hline $\begin{array}{l}\text { Moderate conventional } \\
\text { oil and gas potential }\end{array}$ & Greater than $10-1,000$ \\
\hline Crystalline rocks & Greater than $1,000-3,000$ \\
\hline $\begin{array}{l}\text { Tri-County planning area } \\
\text { boundary }\end{array}$ & $\begin{array}{l}\text { Greater than } 3,000-10,000 \\
\text { Greater than } 10,000-35,000\end{array}$ \\
\hline Groundwater well & Greater than 35,000 \\
\hline
\end{tabular}

Figure 24. Distribution of total dissolved solids concentrations in surface water in the Tri-County planning area, New Mexico, 19862016 (U.S. Geological Survey, 2017c). 


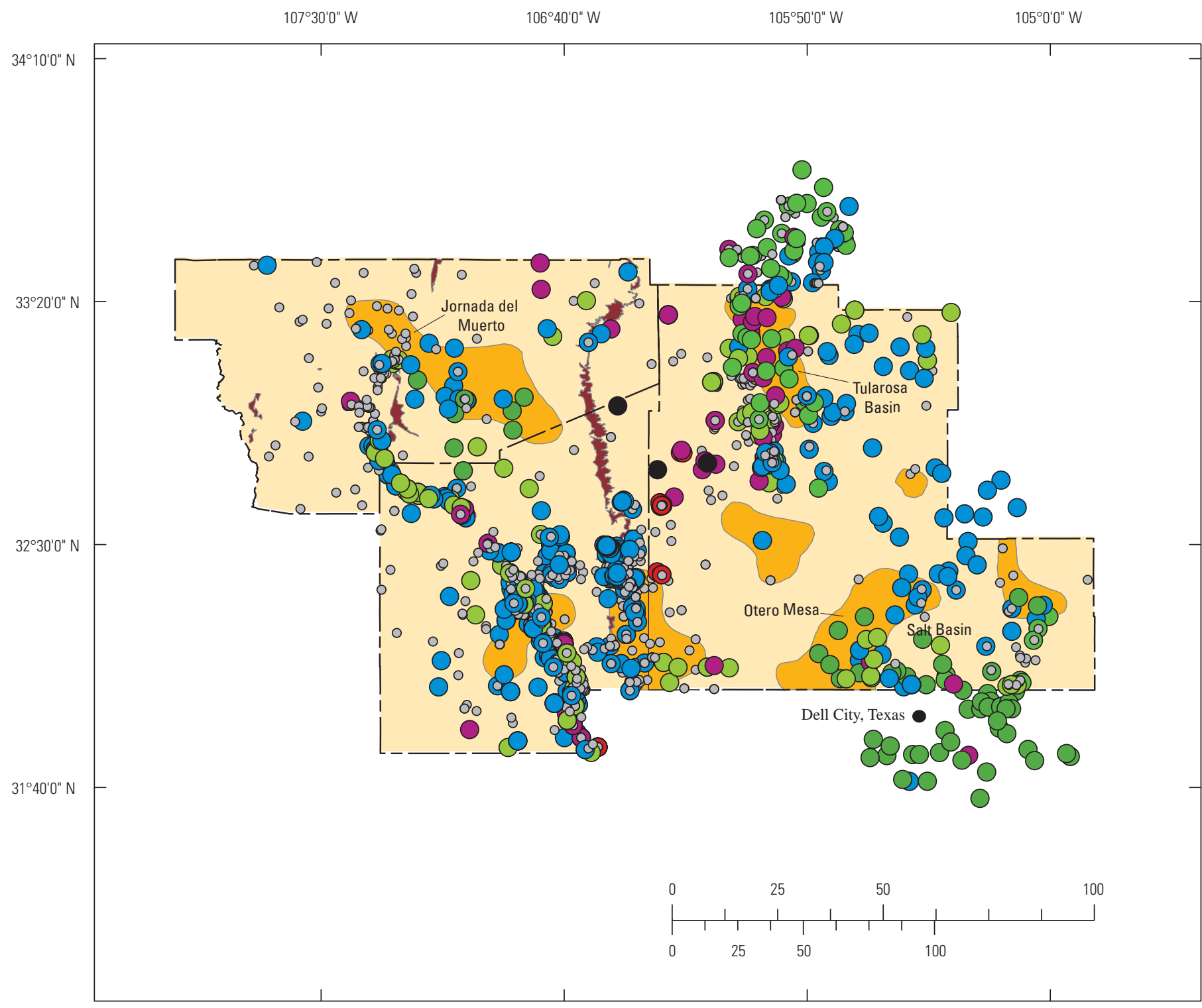

Base map from Bureau of Land Management, 2017

\section{EXPLANATION}

\begin{tabular}{|c|c|}
\hline High conventional oil and & Total dissolved solids, in milligrams per liter \\
\hline gas potential & Not measured or less than 10 \\
\hline $\begin{array}{l}\text { Moderate conventional } \\
\text { oil and gas potential }\end{array}$ & Greater than $10-1,000$ \\
\hline Crystalline rocks & Greater than $1,000-3,000$ \\
\hline $\begin{array}{l}\text { Tri-County planning area } \\
\text { boundary }\end{array}$ & $\begin{array}{l}\text { Greater than } 3,000-10,000 \\
\text { Greater than } 10,000-35,000\end{array}$ \\
\hline Groundwater well & Greater than 35,000 \\
\hline
\end{tabular}

Figure 25. Distribution of total dissolved solids concentrations in groundwater in the Tri-County planning area, New Mexico, $1986-2016$ (U.S. Geological Survey, 2017c). 
Table 4. Total dissolved solids range for freshwater, brackish water, saline water, and brine.

[TDS, total dissolved solids; $\mathrm{mg} / \mathrm{L}$, milligrams per liter; >, greater than; from Watson and others (2003) and Newton and Land (2016)]

\begin{tabular}{ll}
\hline \multicolumn{1}{c}{ Type } & \multicolumn{1}{c}{ TDS } \\
\hline Freshwater & Less than $1,000 \mathrm{mg} / \mathrm{L}$ \\
Slightly Brackish & 1,000 to $3,000 \mathrm{mg} / \mathrm{L}$ \\
Brackish & 3,000 to $10,000 \mathrm{mg} / \mathrm{L}$ \\
Saline & 10,000 to $35,000 \mathrm{mg} / \mathrm{L}$ \\
Brine & $>35,000 \mathrm{mg} / \mathrm{L}$ \\
\hline
\end{tabular}

\section{Water Use}

Water use in the Tri-County planning area varies by county, groundwater or surface-water withdrawals, and wateruse type such as agriculture, domestic, or industrial. Doña Ana County has the largest population as well as the largest water use, nearly 450,000 acre-ft, in the Tri-County planning area. Sierra County has the smallest population, but the second largest water use overall because of reservoir evaporation from Elephant Butte and Caballo Reservoirs (table 5). The population of Otero County is nearly 64,000 , which is more than Sierra County and less than Doña Ana County, and uses the smallest amount of water, about 34,000 acre-ft. Within these three counties, irrigated agriculture uses the largest volume of water followed by reservoir evaporation and public water supply (Longworth and others, 2013). Additionally, the Salt Basin water supply in Otero County is affected by the farming community of Dell City, Texas, where water from the Texas side of the Salt Basin is used for extensive irrigation (Sharp and others, 1993).
Two decades of water-use data were compiled from the New Mexico Office of the State Engineer and the New Mexico Interstate Stream Commission (fig. 26). From 1990 to 2010, domestic self-supplied water use decreased by more than half in Doña Ana County, while use in Otero and Sierra Counties was relatively constant. The use of water in mining substantially increased from 2005 to 2010 in Otero County. In Doña Ana and Sierra Counties, the use of water for mining was relatively low and somewhat constant during the two decades. It is important to note that the highest volume of water used for mining was just under 300 acre-ft while the highest volume of water used for domestic use was nearly 2,500 acre-ft.

\section{Water Resource Administration: Physical and Legal Water Availability}

The State of New Mexico has physical and legal constraints on water use. Physically, some water, such as deep groundwater, may be difficult to access or may have water-quality issues. The Tri-County planning area is located in the arid to semi-arid region of the southwest, where surface water is not naturally abundant. Legally, anyone wanting to use surface water or groundwater in New Mexico must have a permit from the New Mexico Office of the State Engineer and the New Mexico Interstate Stream Commission (NMOSE) (2017a). The surface-water resources in the Tri-County planning area are sparse, and most of the water is appropriated under New Mexico water rights (New Mexico Office of the State Engineer and the New Mexico Interstate Stream Commission, 2017a). Groundwater rights are administered based upon the declared groundwater basins shown in figure 16 , and a permit is required to drill a well to appropriate water for beneficial use or to change an existing water right in these basins; however, these rights

Table 5. Water use in Sierra, Doña Ana, and Otero Counties, New Mexico, 2010 (Longworth and others, 2013).

[*, self-supplied; SW, surface-water withdrawal; GW, groundwater withdrawal]

\begin{tabular}{|c|c|c|c|c|c|c|c|c|c|c|c|c|}
\hline \multirow[t]{2}{*}{ County } & \multirow[t]{2}{*}{$\begin{array}{l}\text { Popula- } \\
\text { tion }\end{array}$} & \multirow[t]{2}{*}{$\begin{array}{l}\text { Water } \\
\text { type }\end{array}$} & $\begin{array}{l}\text { Commer- } \\
\text { cial* }^{*}\end{array}$ & $\begin{array}{l}\text { Domes- } \\
\text { tic* }\end{array}$ & $\begin{array}{l}\text { Indus- } \\
\text { trial* }\end{array}$ & $\begin{array}{l}\text { Irrigated } \\
\text { agriculture }\end{array}$ & $\begin{array}{l}\text { Live- } \\
\text { stock* }\end{array}$ & Mining*, & Power* & $\begin{array}{l}\text { Public } \\
\text { water } \\
\text { supply }\end{array}$ & $\begin{array}{l}\text { Reservoir } \\
\text { evapora- } \\
\text { tion }\end{array}$ & Total \\
\hline & & & \multicolumn{10}{|c|}{ (acre-feet) } \\
\hline Sierra & 11,988 & SW & 0 & 0 & 0 & 21,397 & 28 & 0 & 0 & 0 & 100,620 & 122,045 \\
\hline Sierra & & GW & 1,709 & 168 & 0 & 23,662 & 536 & 17 & 0 & 1,668 & 0 & 27,760 \\
\hline Doña Ana & 209,233 & SW & 0 & 0 & 0 & 271,569 & 148 & 0 & 0 & 0 & 0 & 271,717 \\
\hline Otero & 63,797 & SW & 189 & 0 & 0 & 6,741 & 104 & 0 & 0 & 4,831 & 0 & 11,865 \\
\hline Otero & & GW & 1,655 & 613 & 33 & 15,928 & 114 & 273 & 0 & 3,894 & 0 & 22,510 \\
\hline $\begin{array}{l}\text { Total (acre- } \\
\text { feet) }\end{array}$ & & & 11,428 & 1,434 & 153 & 461,208 & 5,175 & 364 & 1,966 & 51,827 & 100,620 & 634,175 \\
\hline
\end{tabular}

${ }^{1}$ The mining category includes water used for oil and gas production and mining operations. 


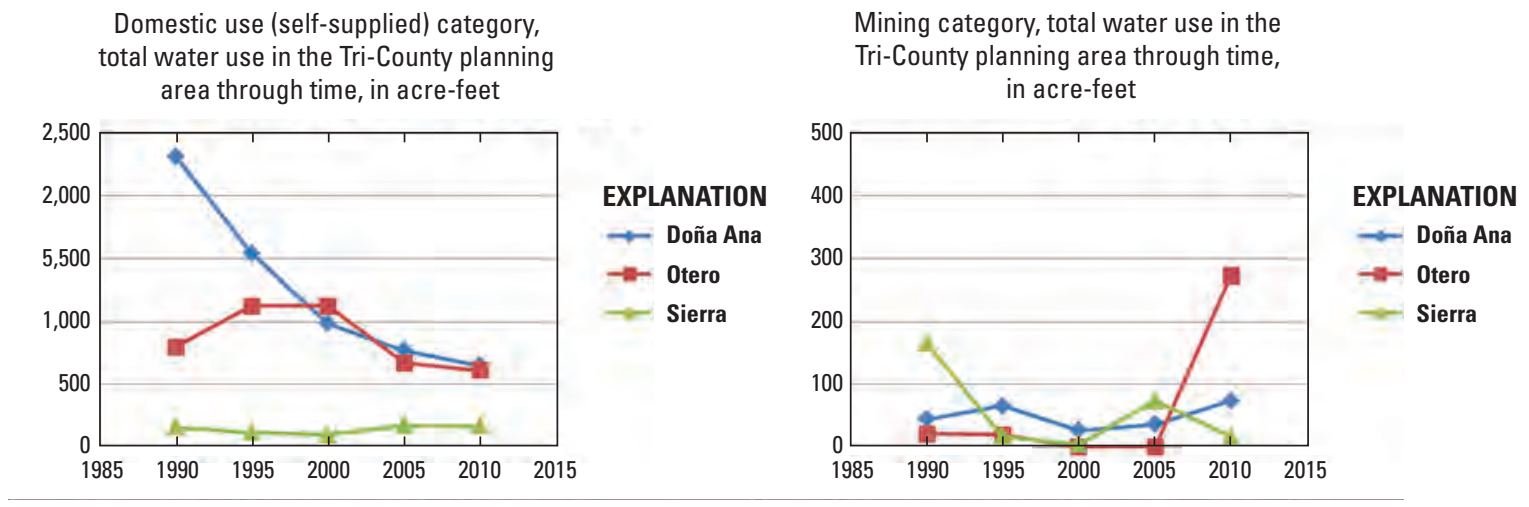

Figure 26. Self-supplied domestic water use and mining water use by county from 1990 to 2010, Tri-County planning area, New Mexico (New Mexico Office of the State Engineer and the New Mexico Interstate Stream Commission, 2017b).

are not all administered in the same manner in the various basins. For example, the Tularosa Basin has administrative guidelines that include critical management areas that could affect additional groundwater development in the Tularosa Basin area of interest, while no basin-specific administrative scheme has been established for the Jornada del Muerto or Salt Basin.

If the top of an aquifer is $2,500 \mathrm{ft}$ or more below the land surface, the aquifer contains only nonpotable water (defined as water with a TDS of 1,000 parts per million or greater), and that aquifer has not been separately declared by the State Engineer, a permit is not required to appropriate water (New Mexico Office of the State Engineer and the New Mexico Interstate Stream Commission, 2017a). However, a notice of intention to drill a well into such an aquifer must be filed with the State Engineer. No such deep nonpotable aquifers have been declared in the Tri-County planning area. If such an aquifer is declared, appropriation of water for oil and gas exploration and development, prospecting, mining, road construction, agriculture, power generation, industrial, and geothermal purposes would not require a permit, and only the notice of intention would be required (New Mexico Office of the State Engineer and the New Mexico Interstate Stream Commission, 2017a). Any other uses from a declared deep nonpotable aquifer, such as municipal use, would require a permit.

There are approximately 40 million acre-ft of groundwater estimated to be in storage in the Jornada del Muerto (Terracon and others, 2004). This value may not take into account water rights, water quality, or access constraints such as land ownership. The population of Otero County relies heavily on surface water, from Three Rivers, Tularosa Creek, the Sacramento River, and some smaller creeks that have ephemeral flow off the Sacramento Mountains, for municipal supply (Livingston Associates, P.C., and John Shomaker and Associates, Inc., 2002). Groundwater in the county ranges from freshwater to brine, but supply is limited because of water rights, quantity, quality, and land ownership (Livingston Associates, P.C., and John Shomaker and Associates, Inc., 2002). More than half of the fresh groundwater near Alamogordo is under military-owned land and therefore not accessible (Livingston Associates, P.C., and John Shomaker and Associates, Inc., 2002). In the 40-year water development plan for the City of Alamogordo, desalination of brackish groundwater through the Alamogordo Regional Supply Project has been listed as a viable option to reduce the reliance on surface waters (Livingston Associates, P.C., and John Shomaker and Associates, Inc., 2006).

The combined available groundwater supply in the Tularosa Basin and Salt Basin is estimated to be approximately 470,000 acre-ft/yr; however, the total recharge in both basins is estimated to be 121,000 acre-ft/yr (Livingston Associates, P.C., and John Shomaker and Associates, Inc., 2002). Additionally, the water in these basins may have high concentrations of TDS, making the water undrinkable or unusable for irrigation or oil and gas development in its current state.

The NMOSE has published data about the estimated water availability in different counties and basins (table 6; New Mexico Office of the State Engineer and the New Mexico Interstate Stream Commission, 2017a). In Socorro and Sierra Counties, the combined groundwater and surfacewater availability is $300,000 \mathrm{acre}-\mathrm{ft} / \mathrm{yr}$ during nondrought periods. Doña Ana County has 440,000 acre-ft/yr of estimated available groundwater and surface water. NMOSE estimates available groundwater in the Tularosa and Salt Basins combined as 22,444 acre-ft/yr in 2060 , based on water quality and water rights in the area. If aquifers are depleted, the administrative water supply (total withdrawals) may not be sustainable in the future. Additionally, NMOSE estimated water availability during a severe drought or a 20 -year drought (table 6). 
Table 6. Water-use availability in Sierra, Doña Ana, and Otero Counties, New Mexico (New Mexico Office of the State Engineer and the New Mexico Interstate Stream Commission, 2016).

\begin{tabular}{|c|c|c|c|}
\hline County/location & Water type & $\begin{array}{c}\text { Estimated water } \\
\text { availability } \\
\text { (acre-feet per year) }\end{array}$ & Supply category \\
\hline Socorro-Sierra & GW/SW & 145,000 & Severe-drought-adjusted administrative supply. \\
\hline Doña Ana & GW/SW & 440,000 & Administrative supply. \\
\hline Doña Ana & GW/SW & 230,000 & Severe-drought-adjusted administrative supply. \\
\hline Otero/Tularosa Basin & GW & 9,611 & 20-year drought 2060 estimate. \\
\hline Otero/Salt Basin & GW & 9,980 & No drought 2060 estimate. \\
\hline Otero/Salt Basin & GW & 2,456 & 20-year drought 2060 estimate. \\
\hline
\end{tabular}

The Salt Basin straddles the New Mexico-Texas border. On the Texas side of the border, the town of Dell City uses groundwater for irrigation, and there has been interest in using some of the groundwater for the benefit of the City of El Paso (New Mexico Office of the State Engineer and the New Mexico Interstate Stream Commission, 2017b). In the Salt Basin, precipitation is very low (10 in/yr) and evaporation rates are very high, which leads to recharge occurring mainly during high-intensity storm events (Sigstedt and others, 2016). Ephemeral streams and the Sacramento River contribute an estimated 60,000 acre-ft of annual flow into the Salt Basin (Tillery, 2011). Groundwater pumping for irrigation in Dell City, Texas, contributes to the majority of groundwater withdrawal from the Salt Basin, with water-level declines of about 1.5 feet per year ( $\mathrm{ft} / \mathrm{yr}$ ) near the center of the New Mexico part of the basin (Huff and Chace, 2006). The Salt Basin has been estimated to contain more than 15 million acre-ft of potentially potable and physically available groundwater (Huff and Chace, 2006).

The agricultural area surrounding Dell City, Texas, is called the Hudspeth County Underground Water District No. 1
(HCUWD\#1) (Finch, 2004). As of 2004, the HCUWD\#1 had 36,000 acres of land that could be irrigated. At a rate of 5 acre-ft per acre, 180,000 acre-ft/yr of groundwater pumping from the Salt Basin would be necessary to fully irrigate HCUWD\#1 (Finch, 2004). The Dell City area is irrigated for growing alfalfa, cotton, and chiles (Finch, 2004). Declared water rights on the New Mexico side of the Salt Basin are $80 \mathrm{acre}-\mathrm{ft} / \mathrm{yr}$ for domestic use, $566 \mathrm{acre}-\mathrm{ft} / \mathrm{yr}$ for stock use, 1,499 acre-ft/yr for municipal use, and 47,595 acre-ft/yr for irrigation (Finch, 2004). In 2012, the estimated acreage of irrigated land in the Dell City area was 21,181 acres (HCUWD\#1, 2013). The aquifer used for irrigation is the Bone Spring-Victoria Peak Aquifer. The planning group for Groundwater Management Area \#4 in Texas has declared a desired future condition of zero feet of change in the average groundwater elevation in this aquifer at the end of the 50-year planning period in 2060, and this has been included in the groundwater management plan for HCUWD\#1 (HCUWD\#1, 2013). 


\section{Assessment of Potential Effects on Water Resources from Oil and Gas Development in the Tri-County Planning Area}

Oil and gas development activities may potentially affect the quantity and quality of surface-water and groundwater resources. The potential for excessive water consumption because of evaporation from holding areas, from drawdown, or from overuse is documented (EPA, 2016c), as is the potential for contamination of drinking water sources arising from the disposal of produced hydrocarbon-laden water (Veil and others, 2004; EPA, 2016c), accidental leaks and spills during production, and hydraulic fracturing practices (EPA, 2016c). Broadly speaking, the oil and gas industry is the largest industrial source of volatile organic compound (VOC) emissions and a significant source of methane (EPA, 2016e). Later in this report section, water use, produced water amounts, and water-quality challenges are discussed in relation to oil and gas development in the areas of interest to this study: the Jornada del Muerto, Tularosa Basin, and Otero Mesa.

\section{Drilling Methods}

Oil and gas wells have traditionally been drilled vertically, but new technologies include horizontal drilling, multilateral drilling, extended reach drilling, and complex path drilling (Intermountain Oil and Gas BMP Project, 2015). Horizontal drilling begins as a vertical well that turns to the horizontal within the reservoir rock. This type of drilling reduces surface disturbance because the vertical well can be located as much as a mile from the reservoir. Multilateral drilling allows access to reservoirs at multiple depths. Extended reach drilling allows access to reservoirs at great distances, as many as 5 miles (mi) from the drilling rig. Complex path drilling can have multiple twists and turns to access multiple reservoirs in varying spatial locations (Intermountain Oil and Gas BMP Project, 2015).

Additionally, in the Tri-County planning area, there is potential for coalbed natural gas, which is often referred to as coalbed methane (Intermountain Oil and Gas BMP Project, 2015). Coalbed methane is held in place in a coal seam by groundwater pressure. Coalbed methane wells are typically vertical and contain a pump at the bottom of the well to release water from the coal seam, which reduces pressure in the coal seam and allows the methane to flow to the surface. Additionally, coalbed methane wells are often shallower than oil and gas wells. Coalbed methane wells often are completed at higher well densities on the surface as compared to surfacecompletion densities of conventional natural gas. In 640 acres, there could be as many as eight coalbed methane wells, while conventional gas wells may have only one well per 640 acres.

\section{Water Usage}

\section{Water Usage in Hydraulic Fracturing}

Water is a necessary component of oil and gas development; however, the amount of water used depends upon the type of oil or gas well that is constructed and how long the well is in operation (Scanlon and others, 2014). For example, water use for hydraulic fracturing occurs during well completion and continually decreases throughout the lifetime of the well, which is typically 20 to 30 years (Scanlon and others, 2014). The volume of water required for hydraulic fracturing also depends on whether the oil or gas well is completed vertically or horizontally (EPA, 2016c). Hydraulic fracturing has used between 820,000 gallons per well (gal/well; 2.5 acre-ft/well) and 4,920,000 gal/well (15 acre-ft/well) in some areas of North Dakota and Texas (Scanlon and others, 2014). The closest potential analog to the Tri-County planning area is the Permian Basin, based on proximity and similar geology. In Eddy County, New Mexico, which is part of the Permian Basin, 1.1 million gallons of hydraulic fracturing fluid per well were used for hydraulic fracturing in 2013 (NMOCD, 2017). In New Mexico in 2013, nearly 2 billion gallons of fluid, mostly composed of water, were used for hydraulic fracturing (Sullivan Graham and others, 2015). Although the NMOSE reports that oil and gas production in New Mexico in 2010 accounted for less than 1 percent of freshwater use that year (NMOCD, 2017), water supplies in New Mexico can be locally affected (NMOCD, 2017) by leaking oil and gas wells, produced water, or drilling fluid spills.

\section{Water Usage in Well Construction}

Oil and gas wells are constructed similarly (NMOCD, 2016a). Boreholes (wellbores) are drilled into the land surface, and well casing is lowered into the wellbore (casing strings are welded together as the casing is lowered). To protect the wellbore and adjacent drinking water aquifers (where present), a sufficient volume of cement grout is pumped down the casing to push out from the bottom of the casing and flow up through the well annulus, the space between the inside of the wellbore and outside of the casing, back to the surface. The cement hardens to form a bond between the wellbore and the casing exterior, which seals off the rocks and groundwater surrounding the well from the fluids (water, oil, or gases) flowing within the well. Wells are then tested to ensure integrity (NMOCD, 2016a). Typically, three separate concentric layers of casing and cement are placed between drinking water aquifers and the pipe containing crude oil and or natural gas. New Mexico requirements for cementing, casing, and wellintegrity testing are outlined in 19.15.16 NMAC (NMOCD, 2016a). 
The construction of oil, gas, and coalbed natural-gas wells are said to be either "conventional" or "unconventional." Although distinguishing definitions are vague, conventional well construction is typified by vertical well-casing emplacement into stratigraphic hydrocarbon traps, while unconventional construction is typified by horizontal wellcasing emplacement into hydrocarbon source zones, usually accompanied by hydraulic fracturing of the target hydrocarbon source zone along the well casing to enhance permeability of the target zone and thus to improve production volumes (EPA, 2016b). Horizontal well construction and related hydraulic fracturing requires considerably more water (on average about five times more) than does conventional construction; for example, David Herrell (Bureau of Land Management, written commun., 2016) estimated that recent unconventionally constructed oil and gas wells in the Permian Basin of New Mexico required 7.3 acre-ft of water, on average, while conventionally constructed wells in the same area required only about 1.53 acre-ft (500,000 gallons) of water.

Coalbed methane wells produce a large volume of water when they are new, and the water volume production declines over time (Veil and others, 2004); oil and gas wells produce smaller volumes of this water, and the disposal or re-use of this "produced water" is discussed in the Produced Water Disposal section of this report. The RFDS (Glover, 2015) suggests that only one area, the Jornada del Muerto, has low coalbed natural gas potential, minimizing the associated potential need for produced-water disposal. The remainder of the Tri-County planning area has negligible potential for coalbed natural gas development.

\section{Water Needs for Oil and Gas Well Construction in the Tri-County Planning Area}

Conventional oil and gas well construction in the TriCounty planning area is expected to require a minimum of 1.53 acre-ft $(500,000$ gallons) of water per well, similar to requirements in the nearby Permian Basin, while construction of unconventional wells is expected to require between about 7.3 and 15.75 acre-ft of water per well. David Herrell (Bureau of Land Management, written commun., 2016) estimated that the minimum water requirement for conventional wells is 1.53 acre- $\mathrm{ft}$, and the minimum requirement for unconventional wells is 7.3 acre-ft. Gallegos and others (2015) reported that through 2014, minimum water requirements per well throughout the United States were 2.1 and 15.75 acre-ft for conventional and unconventional wells, respectively.

Glover (2015) predicted that 106 new oil and gas wells, for the most part expected to be completed conventionally, could be installed in the Tri-County planning area between 2015 and 2035. If all 106 wells installed are conventional (identified as the most likely scenario by Glover, 2015) and the minimum volume of 1.53 acre-ft per well is used, 162.18 acre-ft of water will be required for well construction (table 3). BLM records from 2009 show that 10,738 wells had been drilled as many as that time on BLM lands in the
Permian Basin (BLM, 2014). Multipliers for water needs for unconventional (horizontally or directionally drilled and hydro-fractured wells) vary between about 5 and 10 excluding consideration of multipliers of as great as 30 for unconventional wells completed in oil shales (Gallegos and others, 2015). If all 106 wells are unconventional, between 770 and 1,700 acre-ft of water will be required for well construction. If 15 percent of wells are unconventional and 85 percent of wells are conventional, as much as 380 acre-ft of water will be required for well construction.

Water supplies in New Mexico are generally allocated through water rights (Terracon and others, 2004; New Mexico Office of the State Engineer and the New Mexico Interstate Stream Commission, 2017). Water supply availability in the Tri-County planning area is variable. The groundwater supplies in the Jornada del Muerto and Hueco Basin are generally fixed because annual recharge is low (Terracon and others, 2004). The total amount of water, including available and unavailable, in the Tularosa Basin and Salt Basin combined is estimated to be approximately $470,000 \mathrm{acre}-\mathrm{ft} / \mathrm{yr}$, but the total recharge in these basins is estimated to be 121,000 acre-ft/yr (Livingston Associates, P.C., and John Shomaker and Associates, Inc., 2002). This includes water, such as brine, with high TDS. The total withdrawals from the Tularosa and Salt Basins, or administrative supply, is $22,444 \mathrm{acre}-\mathrm{ft} / \mathrm{yr}$, according to the NMOSE.

\section{Water Usage Related to Oil and Gas Development in the Jornada del Muerto}

Based upon estimates from Glover (2015), 25 coalbed methane wells could be drilled in the Jornada del Muerto during the 2015-35 planning period. These estimates are based on the assumption that "future activity will remain similar to current levels, oil and gas prices will follow the Energy Information Administration projections (U.S. Energy Information Administration, 2015), and new development will be restricted to areas where recent drilling occurred" (Glover, 2015). If all wells are completed conventionally, a minimum of 38.25 acre-ft of water will be needed for all wells, and if all wells are completed unconventionally, about 380 acre-ft of water will be needed for all wells.

\section{Water Usage Related to Oil and Gas Development in the Tularosa Basin}

In the Tularosa Basin, Glover (2015) estimated that 18 oil and gas wells could be drilled during the 2015-35 planning period. These estimates are based on the assumption that "future activity will remain similar to current levels, oil and gas prices will follow the Energy Information Administration projections (U.S. Energy Information Administration, 2015), and new development will be restricted to areas where recent drilling occurred" (Glover, 2015). If all wells are completed 
conventionally, a total minimum of 27.5 acre-ft of water will be needed, and if all wells are completed unconventionally, a total of about 275 acre-ft of water will be needed.

\section{Water Usage Related to Oil and Gas Development in Otero Mesa}

In Otero Mesa (including the Bennett Ranch Unit), Glover (2015) estimated that as many as 44 oil and gas wells will be drilled. These estimates are based on the assumption that "future activity will remain similar to current levels, oil and gas prices will follow the Energy Information Administration projections (U.S. Energy Information Administration, 2015), and new development will be restricted to areas where recent drilling occurred" (Glover, 2015). If all wells are completed conventionally, a total of about 67 acre-ft of water will be needed, and if all wells are completed unconventionally, a total of about 670 acre- $\mathrm{ft}$ of water will be needed.

\section{Produced Water}

Waste products related to oil and gas development include produced water, pipes, well casings, fittings, drilling fluid wastes such as mud or crude oil sludge, and spills from storage tanks or trucks (Nadim and others, 2000; Mansurov and others, 2001). Produced water is the largest volume of waste associated with oil and gas production (Guerra and others, 2011). The generation of produced water increases over time in conventional oil and gas pumping (Guerra and others, 2011). In unconventional oil and gas development, however, the generation of produced water is smaller, because targeted reservoirs are located in shale formations, which are tight reservoirs (Guerra and others, 2011).

\section{Water Quality of Produced Water and Drilling Fluids}

Produced water is the water that is produced as a byproduct of oil and gas extraction. The estimated volume of produced water in the United States is between 840 billion gallons and 1 trillion gallons annually (Harkness and others, 2015). Produced water can contain oil, grease, elevated salt content, and organic or inorganic compounds such as benzene, 2-butanone, n-alkanes, phenol, toluene, barium, boron, iron, nickel, arsenic, and zinc (Veil and others, 2004), as well as the occurrence of radioactive constituents including uranium, thorium, radium, and various decay products (Veil and others, 2004; EPA, 2016e); however, it is unknown if radioactive constituents exist in the three areas of interest in this study. Further data collection and analysis would be needed to assess this. Hydraulic fracturing fluid contains water and sand, an acid such as hydrochloric or muriatic acid, a friction reducer such as polyacrylamide or mineral oil, a surfactant such as isopropanol, a salt such as potassium chloride, a scale inhibitor such as ethylene glycol, a pH-adjusting agent such as sodium or potassium carbonate, an iron control such as citric acid, a corrosion inhibitor such as $\mathrm{N}, \mathrm{N}$-dimethylformamide, and a biocide such as glutaraldehyde (Gregory and others, 2011). The majority of the fluid is water and sand. The chemistry of produced water is often a concern in areas of oil and gas drilling. Surface-water and groundwater resources can be at risk of negative effects from produced water because of spilling or leaking during production, spilling during transport, or migration into water resources after re-injection. In addition, soils may be affected by oil and gas development in a number of ways including spilling produced water or other wastes onto soil, which could adsorb and stay put or adsorb and remobilize; waste from drilling may contain hydrocarbons, salts, radioactive materials, or other toxic chemicals such as arsenic (Nadim and others, 2000; Veil and others, 2004). Produced water stored in pits or evaporation ponds may also leach into the soil (Guerra and others, 2011).

A major concern for water quality in reference to produced waters, which are generally saline to brine, is the TDS concentrations. In the Williston Basin of Montana, North Dakota, and South Dakota, an increase of saline and brine water was found in surface water and shallow groundwater in proximity to oil and gas development (Gleason and Tangen, 2014). In the Williston Basin, brine may migrate from buried reserve pits of produced water, be released from pipeline failures or poor infrastructure construction, or be released as flow-back water from hydraulic fracturing (Gleason and Tangen, 2014). Horizontal and vertical migration of brine is controlled, in part, by the type of sediments surrounding the brine. In the Williston Basin, the sediments consist of glacial outwash and till, which tend to have high hydraulic conductivity.

The USGS has a produced waters database accessible through the Energy Resources Program (USGS, 2016c). Figure 27 shows the range of TDS in produced waters in the Permian Basin near the Tri-County planning area, at three data points along the Rio Grande in Texas, and at one data point in the Tri-County planning area. All TDS in the produced waters are characterized as slightly brackish to brine (table 4). 


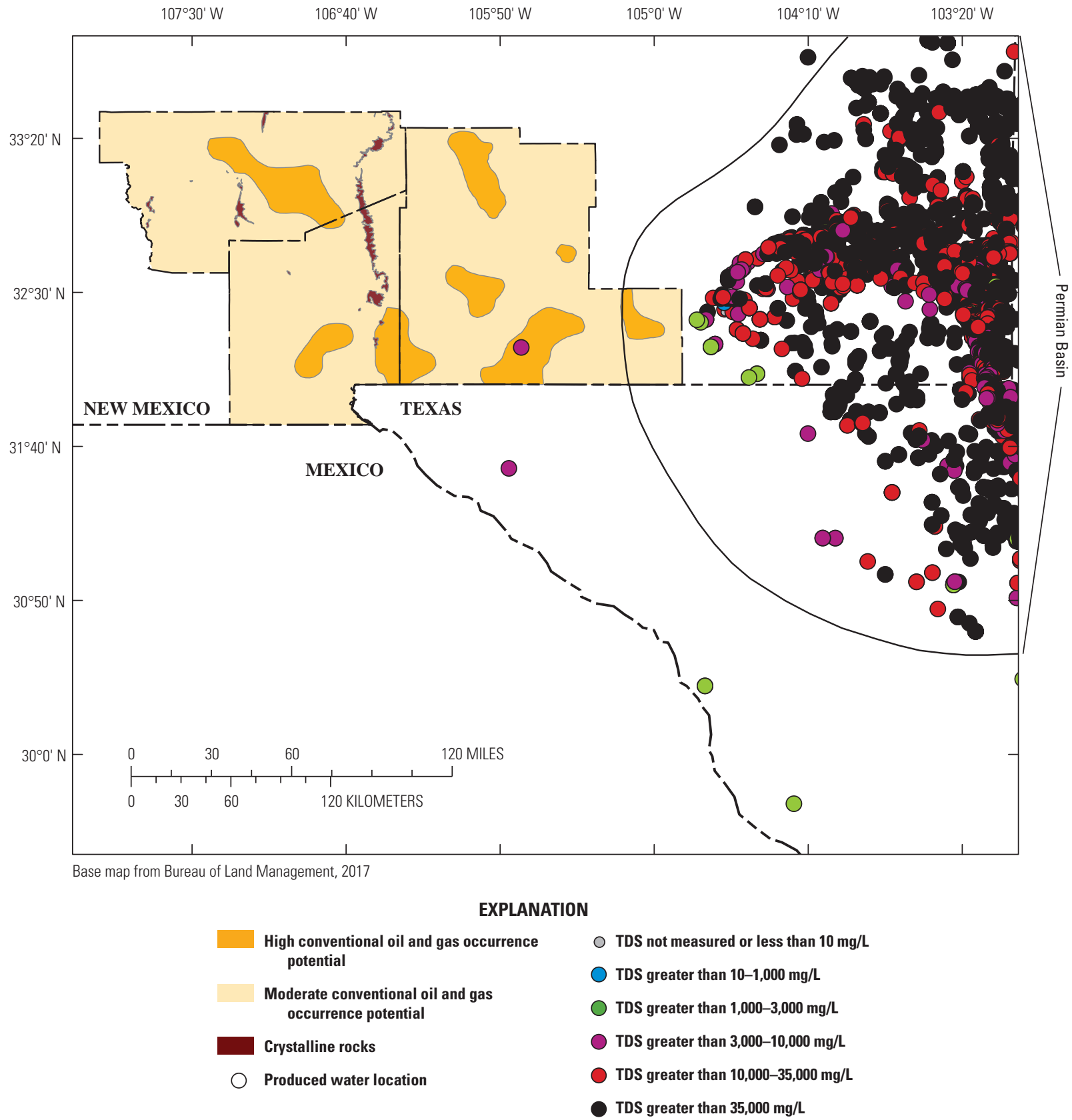

Figure 27. Distribution of total dissolved solids (TDS) concentrations in produced water from oil and gas extraction activities near the Tri-County planning area (U.S. Geological Survey, 2016c). 
In the three areas of interest for this study, the surface deposits are generally alluvium or unconsolidated deposits, which can have high hydraulic conductivity, or ease with which a fluid can move through pore spaces, when sand and silt are the dominant grain size, rather than clay. There is a potential for produced water to reach shallow groundwater, but it will depend on the specific circumstances-drilling location, surficial geology, depth to groundwater, type of production, amounts of water, and how the production equipment is operated. However, the specific rate at which produced water could reach groundwater is unknown without further analysis. In reference to the three areas of interest for this study, in the Jornada del Muerto, the surface deposits specifically consist of Quaternary alluvium made up of clay, silt, sand, and gravel. In the Tularosa Basin, surface deposits are alluvial with some igneous intrusions. In Otero Mesa, there are small areas on the western side where thin sand deposits are underlain by limestone. In the central and eastern parts of the mesa, the surface deposits consist of the Permian Yeso Formation, which is made up of sandstone, limestone, and anhydrite. Limestone and anhydrite have the potential to easily dissolve or contain fractures where fluids could migrate from the surface downward.

\section{Produced Water Disposal}

Produced water disposal practices include land application or discharge, subsurface injection, offsite trucking, application to dirt roads for dust control, and evaporation (Clark and Veil, 2009; Guerra and others, 2011). Land application is relatively inexpensive, but is only an option with high-quality produced waters, such as produced water with low TDS. If the water is of poor quality, the potential for contamination of the soil, water, and vegetation in the area is likely, and alternative disposal methods are used. Subsurface injection of produced waters is the preferred alternative in the industry, however, in some areas, injection is either not allowed or the subsurface formations do not have the capacity to hold the produced waters (Guerra and others, 2011). Offsite trucking of produced water to a location of re-injection is an option, but this increases cost and traffic in the development area and increases cost of disposal. Evaporation of produced waters occurs by discharging the waters into a pond with a large surface area. Produced water evaporation ponds can attract waterfowl, which is potentially dangerous to the waterfowl in the event of exposure to hydrocarbons and other compounds in the water (Clark and Veil, 2009).

Part 39 of New Mexico Energy, Minerals and Natural Resources Department of the Oil Conservation Division, Title 19, Chapter 15, describes special rules related to oil and gas operations (NMOCD, 2016c). These rules are designed to regulate oil and gas operations in areas of particular environmental sensitivity. In the Tri-County planning area, much of Sierra County and parts of Otero County have prohibitions on produced water pits and restrictions on produced water injection wells. Disposal methods used in New Mexico include injection of produced waters deep into the subsurface in Class II underground injection wells (Luna, 2005). The EPA has regulations for injection wells, which are overseen in New Mexico by the NMOCD (Luna, 2005) under Title 40 of the Code of Federal Regulations, Subpart D, Section 144.3 I (c)(1). The five pathways of contamination related to injection wells as described by the EPA include faulty well construction, nearby wells leaking, faults or fractures in confining strata, direct injection, and displacement of injected fluids (EPA, 2002).

Produced water injection back into the Salt Basin could be problematic given the fractured nature of the aquifers in the basin (Luna, 2005). The Otero Break is an important fracture system in the Salt Basin. Fractured aquifers have variable and complex flow paths, which could potentially increase mobility of produced water injection.

Injection-induced seismicity (or earthquakes) is an increasing concern in areas of oil and gas production (Ellsworth, 2013). Without detailed inspection of proposed injection locations, it is difficult to speculate on specific effects related to the injection of produced water.

\section{Produced Water Reuse}

Recently, reuse of produced water from oil and gas development has been described by Guerra and others (2011) and Sullivan Graham and others (2015), the utility of which depends upon water chemistry. The chemistry of produced waters varies, depending on the local geology, water quality, and chemicals used during drilling. Concentrations of constituents in produced waters and the intended use of the waters govern the type and cost of treatment as well. If treated, produced water can be used for crop irrigation, livestock watering, and streamflow augmentation, can be used for municipal and industrial needs, and can be placed in aquifer storage for future use (Guerra and others, 2011). Additionally, saline produced water may be reused for oil and gas drilling, fracturing, and completion (Sullivan Graham and others, 2015). In areas of limited freshwater resources, such as the Permian Basin of New Mexico, produced water reuse could help to alleviate stress on these resources (Sullivan Graham and others, 2015). In the Permian Basin of southeast New Mexico, 170 billion gallons of water was produced in association with oil and gas production between 2008 and 2013 (Sullivan Graham and others, 2015).

As of 2004, the NMOCD regulates the disposal of produced water to allow reasonable protection against contamination of freshwater resources. However, no permit is necessary to reuse produced waters or drilling fluids as long as the fluids are not in contact with freshwater zones (NMOCD, 2004). 


\section{Vulnerability of Ground water and Surface Water in the Tri-County Planning Area}

Oil and gas exploration has the potential to affect water quality through spillage or the storage of drilling fluids in surficial impoundments and subsequent seepage into shallow groundwater at the water table. As oil fields are developed, transportation of hydrocarbon fluids by truck or pipeline also adds to the risk of accidental releases. Transportation integrity is regulated in New Mexico by the U.S. Department of Transportation, the NMOCD, or the Pipeline and Hazardous Materials Safety Administration (http://www.phmsa.dot.gov/). The NMOCD has rules about disposal of waste products related to oil and gas that may restrict disposal, depending on local conditions (Title 19, Chapter 15 of the New Mexico Administrative Code).

Glover (2015) identified potential effects of, and potential future development for, oil, gas, and coal-bed natural gas in the Jornada del Muerto, the Tularosa Basin, and Otero Mesa (fig. 2), as well as the potential adverse effects of that development. In the following sections, the vulnerability of groundwater and surface water in these three areas of interest and in Doña Ana County is discussed in detail.

\section{Jornada del Muerto}

In Sierra County, 35 dry and abandoned gas or oil and gas wells range in total depth from 127 to $11,650 \mathrm{ft}$ below land surface (Glover, 2015). It is unknown if the wells are properly plugged. In the Jornada del Muerto, the sandstone portion of the Percha Formation has oil reservoir potential, and the shale has oil confinement potential (Albright and others, 1955). The Percha Shale is located between 8,350 and $8,500 \mathrm{ft}$ below land surface (table 1). Additionally, the McRae Formation, a Tertiary-Cretaceous coal-bearing sandstone and shale is located between 1,450 and $1,539 \mathrm{ft}$ below land surface (table 1). In central Sierra County, shallow unconfined groundwater of the Santa Fe Formation and of otherwise undifferentiated alluvium in the Jornada del Muerto is the primary groundwater supply that is vulnerable to accidental releases (USGS, 2017c). Based on historical USGS groundwater-level measurements, the average depth to groundwater in this area is about $61 \mathrm{ft}$ below land surface (USGS, 2017c).

Figure 28 combines the area of high conventional oil and gas occurrence potential and low coalbed gas development potential with the locations of streams, known groundwater wells, and oil and gas wells, which are mostly abandoned. The locations of groundwater wells shown are within $30 \mathrm{mi}$ of the high conventional oil and gas occurrence potential area in the Jornada del Muerto. Of particular note are the oil and gas wells located near the low coalbed gas development potential. Oil and gas wells in this area range in depth from $127 \mathrm{ft}$ to as much as 2,630 ft. As noted previously, the alluvial deposits in this area are important aquifers. Groundwater depths near these oil and gas wells range from $0-10 \mathrm{ft}$ to 50-100 ft. If shallow oil and gas wells in the area are drilled, there is a potential for the oil and gas wells to leak into the shallow aquifer system. Additionally, if there are surface leaks from trucks carrying produced water, the alluvial aquifer could be vulnerable. Oil and gas wells surrounding the high conventional oil and gas occurrence potential area in the Jornada del Muerto have been drilled as deep as $11,650 \mathrm{ft}$ below land surface. While these depths may not come into contact with an aquifer, there is still the potential for groundwater vulnerability near the surface in the shallow aquifer system. Surface water in the area includes the Rio Grande and nearby Elephant Butte and Caballo Reservoirs (fig. 13). Because of the groundwater flow paths and relative direction to nearby streams, leaks from the oil and gas well casing or on the surface could flow into tributaries of the Rio Grande (fig. 18).

\section{Tularosa Basin}

Glover (2015) identified that potential occurrence, and thus potential future development, of oil and gas is possible in north-central Otero County in the Pennsylvanian and Permian rocks of the Tularosa Basin (King and Harder, 1985). Two temporary abandoned gas wells, the Jalapeno Corporation Cowboy 27 (latitude 33.157319 ${ }^{\circ}$, longitude $-105.95874^{\circ}$ ) and the Cibola Energy Corporation Ysletano Canyon Federal 1 (latitude $33.10851^{\circ}$, longitude $-105.905395^{\circ}$ ), were drilled in the northern Tularosa Basin and had significant gas zones (Glover, 2015). The total depths below land surface of these wells are 4,650 and 5,028 ft, respectively. The Percha Shale is noted in the literature to have potential as a petroleum source rock (Albright and others, 1955). In northern Otero County, the shallow unconfined alluvial groundwater of the Tularosa Basin is the primary groundwater supply that is vulnerable to accidental releases (USGS, 2017c). Groundwater data in this area indicate that the average depth to water is about $298 \mathrm{ft}$ below land surface (USGS, 2017c). 


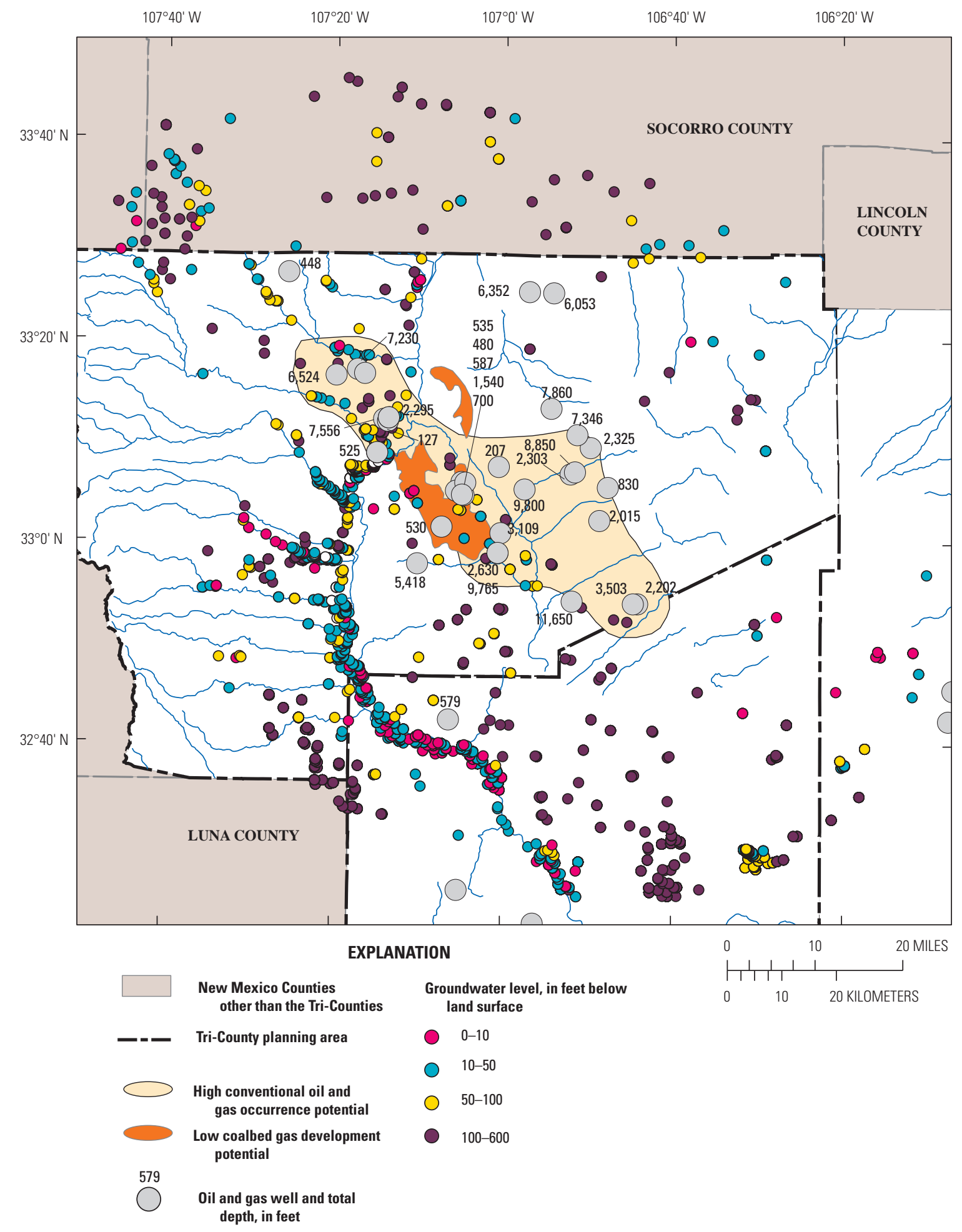

Figure 28. Locations and depths of oil and gas wells, locations of groundwater wells, and ranges of groundwater levels near the Jornada del Muerto, New Mexico. 
Figure 29 combines the areas of high conventional oil and gas occurrence potential and very low conventional oil and gas development potential with the locations of streams, known groundwater wells, and oil and gas wells, which are mostly abandoned. The locations of groundwater wells shown are within $30 \mathrm{mi}$ of the high oil and gas conventional occurrence potential area in the Tularosa Basin area of interest. In general, oil and gas wells in this area are deep, from 3,040 ft below land surface to as much as $9,852 \mathrm{ft}$ below land surface. However, there are two wells that are shallower, at $555 \mathrm{ft}$ and $715 \mathrm{ft}$ below land surface. The primary aquifer in this region is alluvial deposits, which can be vulnerable to leaking oil and gas wells or surface leaks. Groundwater levels in wells in the area range from 0 to $630 \mathrm{ft}$ below land surface. As mentioned in the Water Quality section of this report, water quality in the Tularosa Basin is greatly affected by high TDS concentrations. Water used for oil and gas development in the area may cause challenges related to water quality; however, some companies are working to develop ways to use high TDS water in oil and gas development (Guerra and others, 2011). In general, groundwater flows from the east, down from the mountain slopes, and towards the basin floor in the Tularosa Basin area of interest (fig. 20). The Tularosa Creek, an important surface-water resource in the Tularosa Basin, and Three Rivers (fig. 13) flow in the same direction as the groundwater and could be susceptible to contamination if there was a surface spill or contaminated shallow groundwater.

\section{Otero Mesa}

Oil and gas development in the Tri-County planning area, for the period 2015 through 2035, is expected to be dominated by vertical gas wells with completion depths of less than $10,000 \mathrm{ft}$ in southern Otero County in the vicinity of the Bennett Ranch (Glover, 2015). In 1997, the Bennett Ranch Unit \#1Y had a gas-producing interval in the Helms Formation from 4,506 to 4,518 ft. In 2001, the Bennett Ranch Unit 25-1, located 2 mi southeast of Bennett Ranch Unit \#1Y, had a gas-producing interval in the Magdalena Group from 2,255 to 2,268 ft (Luna, 2005). Broadly described, the reservoirs for the two Bennett Ranch Unit wells are suggested to be within Ordovician, Silurian, Mississippian, and Pennsylvanian deposits as well as a Tertiary igneous intrusion within the Mississippian and (or) Pennsylvanian rocks (Broadhead, 2003). Source rocks of petroleum in this area are Devonian shales, Mississippian shales and limestones, and Pennsylvanian shales and limestones (Broadhead, 2003). In southern parts of Otero County in the vicinity of the potential development area, shallow unconfined groundwater of undifferentiated alluvium is the primary groundwater supply; the average depth to water is about $450 \mathrm{ft}$ below land surface. (Average depth to water calculations excluded data categorized as "confined" and zero-valued depth to water data; calculations were performed irrespective of spatial or temporal data distribution). Little to no surface water is located near the Bennett Ranch Unit, therefore surface-water vulnerability is negligible.

Figure 30 combines the area of high conventional occurrence potential and low and moderate conventional development potential with the locations of streams, known groundwater wells, and oil and gas wells, which are mostly abandoned. The exception on Otero Mesa is the location of the Bennett Ranch wells discussed in the previous paragraph. The locations of groundwater wells shown are within $30 \mathrm{mi}$ of the high conventional oil and gas occurrence potential area in the Otero Mesa area of interest. In general, oil and gas wells in this area are deep, from $1,375 \mathrm{ft}$ below land surface to as much as 7,075 ft below land surface. Groundwater levels are generally deep, from 110 to $800 \mathrm{ft}$ below land surface. The closest cluster of wells to Otero Mesa is located in the Salt Basin, which has TDS concentrations from less than $1,000 \mathrm{mg} / \mathrm{L}$ to as much as $35,000 \mathrm{mg} / \mathrm{L}$. If water from the Salt Basin were used for oil and gas development, TDS values would be an important factor to consider prior to use. As mentioned previously, companies are exploring methods for using high TDS waters in oil and gas development (Guerra and others, 2011). The limited number of wells on Otero Mesa make it challenging to fully assess the vulnerability of groundwater in the area. As with the Jornada del Muerto and the Tularosa Basin, the shallow alluvium is the primary aquifer in this location. Leaking oil and gas wells into the alluvium or surface leaking from produced water transport could cause contamination to the groundwater. Many ephemeral streams or arroyos are located on Otero Mesa and the Salt Basin. If a surface spill occurs in or adjacent to these surface-water resources, summer monsoonal rain could quickly transport contaminants towards the Salt Basin and into the irrigation water used by Dell City, Texas, farmers. In addition, drilling on Otero Mesa has been of concern because of potential impacts to vegetation, wildlife habitat, and groundwater (Finch, 2004; BLM, 2013).

\section{Vulnerability in Doña Ana County}

In central Doña Ana County, shallow unconfined groundwater of the Santa Fe Formation and of undifferentiated alluvium is the most vulnerable to accidental releases of the groundwater supplies in the area because of the shallow depth of the water; the average depth to water is about $30 \mathrm{ft}$ below land surface. Additionally, the shallow groundwater in this area is hydrologically connected to Rio Grande surface waters. In southeast Doña Ana County, shallow unconfined groundwater of Bolson deposits and of undifferentiated alluvium is the most vulnerable to accidental releases of the groundwater supplies in the area because of the unconfined nature of the aquifer; the average depth to water is about $327 \mathrm{ft}$ below land surface. 


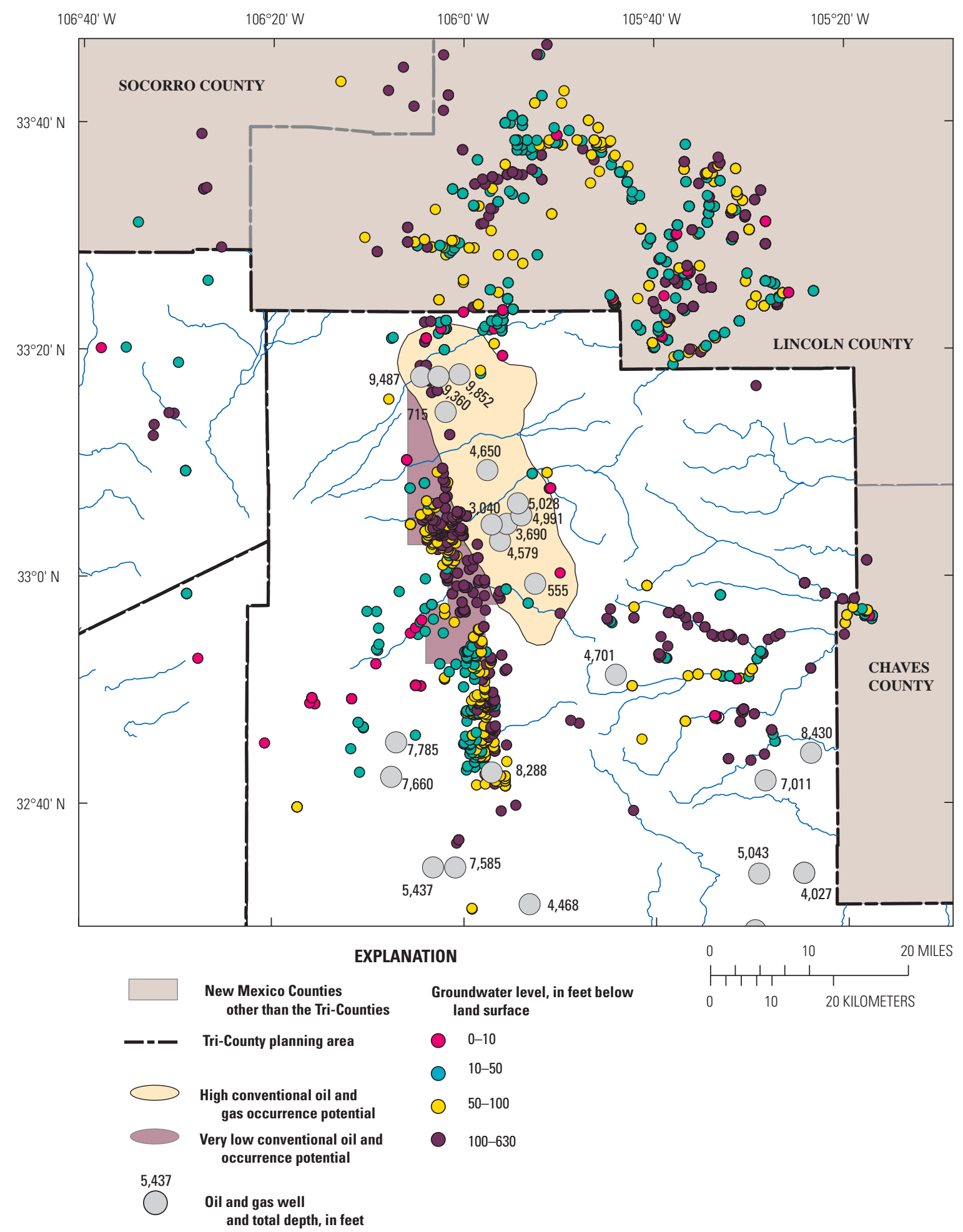

Figure 29. Locations and depths of oil and gas wells, locations of groundwater wells, and ranges of groundwater levels near the Tularosa Basin, New Mexico. 


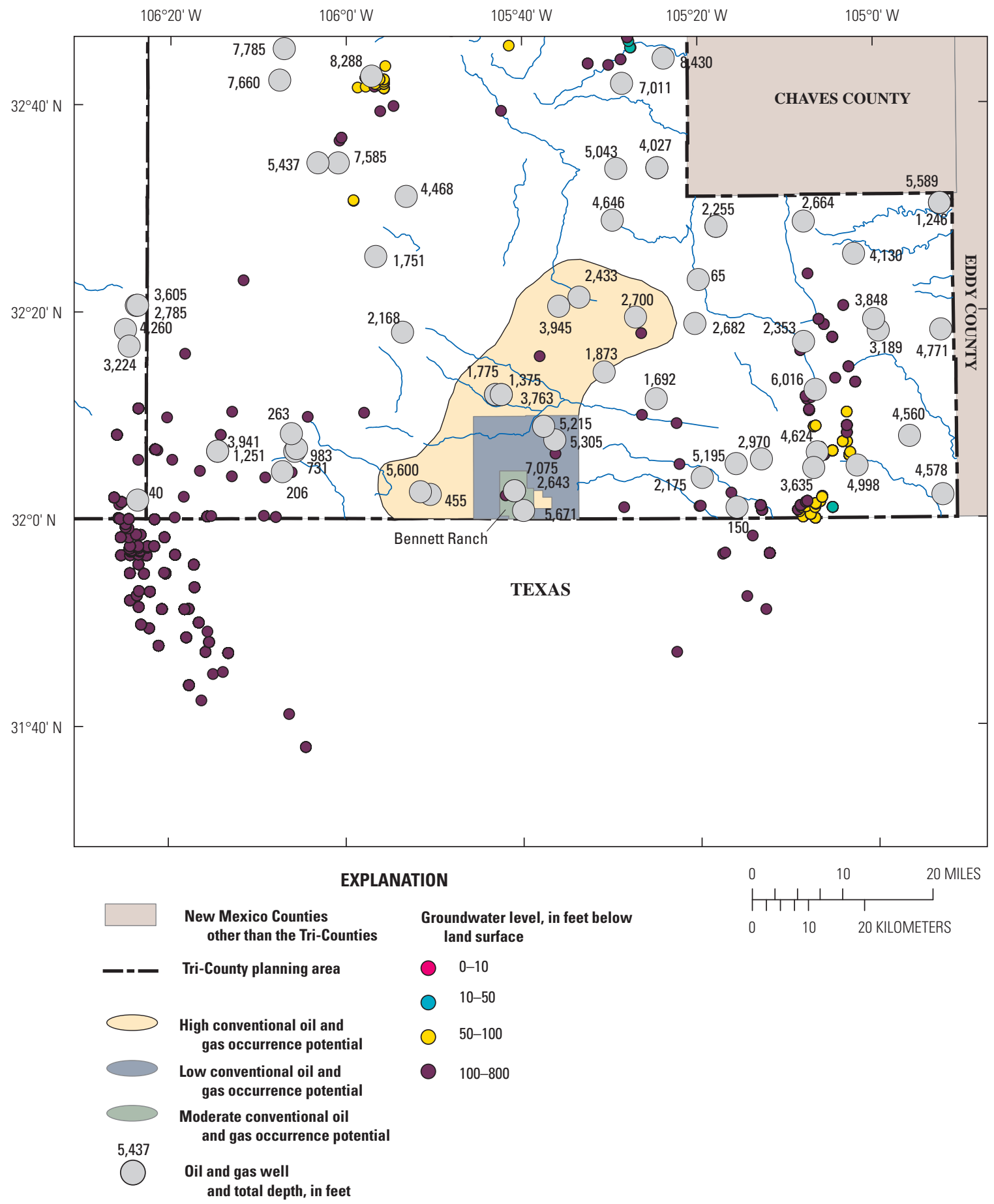

Figure 30. Locations and depths of oil and gas wells, locations of groundwater wells, and ranges of groundwater levels near Otero Mesa, New Mexico. 


\section{Water Quantity Concerns}

The depth to groundwater in the three areas of interestJornada del Muerto, Tularosa Basin, and Otero Mesa-is generally increasing with time, with some decreasing depths suggesting variability of groundwater storage (figs. 19, 21, 23). Given the limited water resources in the location of the Tri-County planning area and in the three areas of interest, water quantity is important to assess when planning oil and gas development. Physical and legal availability will have to be taken into account.

\section{Data Gaps Identified and Suggestions for Further Study}

\section{Assessment of Surface-Water Resources}

Surface-water resources in most of the Tri-County planning area are limited, likely limiting their use for oil and gas development. The Rio Grande, the Elephant Butte and Caballo Reservoirs, and related irrigation are important surface-water resources in the eastern part of the Tri-County planning area. Related data are also limited, difficult to locate, and difficult to interpret. Surface waters in the Tri-County planning area are fully appropriated. Under these very limited conditions, additional study of surface water could help fill in data gaps to distinguish perennially flowing channels from intermittently or ephemerally flowing channels; to identify connectivity between surface-water and groundwater systems; and to characterize effects on surface-water bodies and conjoined groundwater systems from irrigation usage, evaporation, and evapotranspiration. Specific locations to study further include the ephemeral streams and arroyos surrounding Otero Mesa and the Salt Basin. Additionally, ephemeral streams flowing off of the Sacramento Mountains towards the Tularosa Basin could be monitored for streamflow and water quality.

\section{Assessment of Groundwater Resources}

Some areas of interest for high occurrence potential of oil and gas possibilities in the Tri-County planning area have limited historical groundwater-level data available in the USGS NWIS database (USGS, 2017c). The Otero Mesa is lacking recurrent water-level measurements at any one site. Also, some aquifers have many groundwater wells but very limited data available for each well in the USGS NWIS database. There are also temporal data gaps, in some cases for more than a decade, in groundwater measurements at most of the wells, limiting interpretation of trends in groundwater supplies. To obtain more expansive water-level datasets that are inclusive of all aquifers in these areas, the construction and periodic monitoring of additional groundwater observation and monitoring wells could be explored. Specifically, decision makers could use further evaluation of groundwater in the areas of high oil and gas potential discussed in this report to assist in management decisions. As noted, the Salt Basin and Otero Mesa area have few groundwater wells and little associated depth to water data. Adding groundwater monitoring wells in these locations could aid in management decisions by providing additional information about groundwater-levels and groundwater vulnerability. Additionally, more detailed permeability and porosity data of the aquifers in each location could aid in assessing the productivity and sustainability of groundwater supplies. Detailed assessment of smaller areas of interest could provide specific information related to oil and gas development scenarios. This report provides an overview, but further study could provide better information such as the fine-detailed locations of faults, which can be conduits for oil and gas or water, and the permeability of rocks directly adjacent to oil and gas well sites.

\section{Assessment of Water Quality}

The amount of water-quality data is sufficient to assess the distribution of TDS and salt content in the TriCounty planning area. However, increased monitoring of groundwater and surface water in the three areas of interest could aid in the understanding of the geochemistry, and could adequately characterize baseline conditions prior to initiation of any large-scale oil and gas development. Age dating and general geochemical characterization of the current water resources could provide information about the current conditions that would provide baseline information before future development. Indicators of hydrocarbons or evidence of produced water mixing with freshwater, such as stable isotopes of oxygen, hydrogen, strontium, and nitrogen, radioactive isotopes such as radon or uranium, and concentrations of methane, benzene, toluene, ethylbenzene, xylene, chloride, bromide, strontium, boron, or sodium, would be useful to measure before, during, and after oil and gas production to monitor the effects on water resources. 


\section{Summary}

Existing data were used to provide information about the water resources in the Tri-County planning area of Sierra, Doña Ana, and Otero Counties in south-central New Mexico. This report presents information about water resources in the planning area and potential issues that could arise from the construction of oil and gas wells in three areas of interest - the Jornada del Muerto, Tularosa Basin, and Otero Mesa, which is adjacent to the Salt Basin. Detailed geologic descriptions are included to aid in the understanding of the structure, fault locations, rock type, oil and gas potential, and hydrogeologic characteristics of the area.

The Tri-County planning area is located in the eastern Basin and Range Province, where mountain ranges receive recharge in the form of snow and rain, which ultimately flows towards the lower elevation basins through groundwater flow paths and surface-water channels. In general, the amount of available water is small, and much of the surface water and groundwater is allocated by New Mexico water rights. Use of nonpotable groundwater in aquifers starting 2,500 ft below the surface does not require permits, but groundwater at these depths generally has high TDS concentrations.

Surface-water resources are limited in the Tri-County planning area. The Rio Grande is the main perennial river flowing through Sierra and Doña Ana Counties. The Tularosa Creek is an important surface-water resource in the Tularosa Basin, and the Sacramento River, which flows southeast out of the Sacramento Mountains, is an important source of water to aquifers in the Salt Basin.

Groundwater resources in the Tri-County planning area vary in aquifer type, depth to water, and water quality. The Jornada del Muerto, Tularosa Basin, and Salt Basin each have shallow and deep aquifer systems, and water quality can range from freshwater (less than $1,000 \mathrm{mg} / \mathrm{L}$ of TDS) to brine (greater than $35,000 \mathrm{mg} / \mathrm{L}$ of TDS). Water quality in the Tri-County planning area is affected by the dissolution of salt deposits and evaporation which are common in arid regions such as southern New Mexico.

The potential for oil and gas development exists in several areas of the Tri-County planning area, including the Jornada del Muerto, Tularosa Basin, and Otero Mesa. Conventional oil and gas well construction in the Tri-County planning area is expected to require 1.53 acre- $\mathrm{ft}$ of water per well, similar to requirements in the nearby Permian Basin of New Mexico, while construction of unconventional wells is expected to require 7.3 acre- $\mathrm{ft}$ of water per well. If maximum development occurs, 81 new conventional wells and 25 coalbed natural gas wells could be developed by 2035 . Issues related to oil and gas development include the use of limited groundwater resources, the water quality of these resources, potential leaking from oil and gas wells, and the disposal of produced water.

Data gaps identified include the limited detailed data on surface-water resources, the lack of groundwater wells in areas of interest, and the lack of water chemistry data related to oil and gas development issues. Surface waters in the Tri-County planning area are sparse; some streams are perennial, while most are ephemeral. A more detailed study of the ephemeral channels and subsequent interaction with groundwater would provide a better understanding of the usefulness of these surface-water resources. Groundwater data in this study are from the USGS NWIS database, which does not have continuous water-level depth data for many of the sites in the Tri-County planning area. On Otero Mesa, there are no recurrent water-level data at any one well. To fully understand the groundwater resources, it would be helpful to have more wells in specific areas of interest for groundwaterlevel and water-quality measurements. Of additional importance in relation to oil and gas development is the presence of organic constituents as well as the occurrence of radioactive constituents such as uranium or radon. Analyzing water resources for these constituents prior to oil and gas development could provide a baseline of the water chemistry so that if oil and gas wells are constructed, the changes in the quality of nearby surface water and groundwater could be more easily assessed.

\section{References}

Albright, J.L., Alcorn, R., and Cave, H.S., 1955, Oil and gas possibilities of the basins of the Sierra County region, in south-central New Mexico: New Mexico Geological Society 6th Annual Field Conference Guidebook, p. 124135.

Allmendinger, R.J., and Titus, F.B., 1973, Regional hydrology and evaporative discharge as a present-day source of gypsum at White Sands National Monument, New Mexico: New Mexico Bureau of Geology and Mineral Resources Open-File Report 55.

Angles, E.S., 2001, Hydrology of the Salt Basin, in Mace, R.E., Mulican, W.F., III, and Angle, E.S., eds., Aquifers of west Texas: Texas Water Development Board Report 356, p. 232-247.

Anning, D.W., and Flynn, M.E., 2014, Dissolved-solids sources, loads, yields, and concentrations in streams of the conterminous United States: U.S. Geological Survey Scientific Investigations Report 2014-5012, 101 p., accessed April 10, 2017, at http://dx.doi.org/10.3133/ $\operatorname{sir} 20145012$.

Bedinger, M.S., Sargent, K.A., and Langer, W.H., eds., 1989, Studies of geology and hydrology in the Basin and Range Province, southwestern United States, for isolation of highlevel radioactive waste - Characterization of the Rio Grande region, New Mexico and Texas: U.S. Geological Survey Professional Paper 1370-C, 42 p., 7 pls. 
Bhark, E.W., and Small, E.E., 2003, Association between plant canopies and the spatial patterns of infiltration in shrubland and grassland of the Chihuahuan Desert, New Mexico: Ecosystems, v. 6, p. 185-196, accessed November 3, 2016, at https://doi.org/10.1007/s10021-002-0210-9.

Bjorklund, L.J., 1957, Reconnaissance of ground-water conditions in the Crow Flats area, Otero County, New Mexico: State of New Mexico State Engineer Office Technical Report No. 8, 26 p.

Black, B.A., 1973, Geology of the northern and eastern parts of the Otero platform, Otero and Chaves Counties, New Mexico: University of New Mexico, Dissertation, $170 \mathrm{p}$.

Black, B.A., 1975, Geology and oil and gas potential of the northeast Otero Platform area, New Mexico, in Las Cruces Country: New Mexico Geological Society 26th Field Conference Guidebook, p. 323-333.

Black, B.A., 1976, Tectonics of the northern and eastern parts of the Otero platform, Otero and Chaves Counties, New Mexico: New Mexico Geological Society, Special publication number 6, p. 39-45.

Blake, J.M., Shephard, Z.M., Mitchell, A.C., Miltenberger, K.E., Stewart, A.M., Ritchie, A.B., McHugh, A.R., Charles, E.G., and Hopple, J., 2017, Geodatabase supporting the assessment of hydrologic resources and the potential effects from oil and gas development in the Bureau of Land Management Tri-County Planning Area, Sierra, Doña Ana, and Otero Counties, New Mexico: U.S. Geological Survey data release, https://doi.org/10.5066/F7DR2T0M.

Boyd, F.M., 1982, Hydrogeology of the northern Salt Basin of west Texas and New Mexico: The University of Texas at Austin, M.A. Thesis.

Brady, B.T., Mulvhill, D.A., Hart, D., Jr., and Langer, W.H., 1983, Maps showing ground-water levels, springs, and depth to ground water, Basin and Range Province, New Mexico: accompaniment to U.S. Geological Survey WaterResources Investigations Report 83-4118-B.

Broadhead, R.F., 2003, Petroleum geology of the McGregor Range Otero County, New Mexico: American Association of Petroleum Geologists Search and Discovery Article 10052.

Bureau of Land Management [BLM], 2005, McGregor Range, Resource Management Plan Amendment and Environmental Impact Statement, [Las Cruces, N.M.]: U.S. Department of the Interior, Bureau of Land Management, Las Cruces District Office.

Bureau of Land Management [BLM], 2013, Tri-County Draft Resource Management Plan/Environmental Impact Statement: Bureau of Land Management Las Cruces District Office, 475 p., with appendixes, accessed October 3, 2017, at https://archive.org/details/tricountydraftre00unit.
Bureau of Land Management [BLM], 2014, Analysis of the management situation: Roswell.

Butler, W.C., 1988, The rationale for assessment of undiscovered, economically recoverable oil and gas in south-central New Mexico: A geologic overview and play analysis of two favorable areas: U.S. Geological Survey Open-File Report 88-450-B.

Cather, S.M., and Harrison, R.W., 2002, Lower Paleozoic isopach maps of southern New Mexico and their implications for Laramide and Ancestral Rocky Mountain tectonism, in Lueth, V., Giles, K.A., Lucas, S.G., Kues, B.S., Myers, R.G., and Ulmer-Scholle, D., eds., Geology of White Sands: New Mexico Geological Society 53rd Annual Fall Field Conference Guidebook, p. 85-101.

Chafetz, H.S., Meredith, J.C., and Kocurek, G., 1986, The Cambro-Ordovician Bliss Formation, southwestern New Mexico, USA - Progradational sequences on a mixed siliciclastic and carbonate shelf: Sedimentary Geology, v. 49 , p. 201-221.

Cikoski, C.T., and Koning, D.J., 2013, Geologic map of the Huerfano Hill quadrangle, Sierra County, New Mexico: New Mexico Bureau of Geology and Mineral Resources Open-File Geologic Map 243.

Clark, C.E., and Veil, J.A., 2009, Produced water volumes and management practices in the United States: Argonne National Laboratory Environmental Sciences Division, ANL/EVS/R-09/1.

Collins, E., and Jochems, A.P., comps., 2016, Fault number 901, Hueco fault zone, in Quaternary fault and fold database of the United States: U.S. Geological Survey website, accessed July 26, 2017, at https://earthquakes.usgs.gov/ hazards/qfaults.

Conover, C.S., 1954, Ground-water conditions in the Rincon and Mesilla Valleys and adjacent areas in New Mexico: U.S. Geological Survey Water-Supply Paper 1230, 200 p., accessed August 24, 2017, at https://pubs.er.usgs.gov/ publication/wsp1230.

Conover, C.S., Herrick, E.H., Wood, J.W., and Weir, J.E., Jr., 1955, The occurrence of ground water in south-central New Mexico, in Fitzsimmons, J.P., ed., South-central New Mexico: New Mexico Geological Society 6th Annual Fall Field Conference Guidebook, 193 p.

Darton, N.H., 1921, Geologic structure of parts of New Mexico, in Contributions to economic geology, Part II: U.S. Geological Survey Bulletin 726-E, p. 173-275.

Darton, N.H., 1928, "Red beds" and associated formations in New Mexico, with an outline of the geology of the State: U.S. Geological Survey Bulletin 794, 356 p. 
Davie, W., Jr., and Spiegel, Z., 1967, Las Animas Creek Hydrographic Survey Report: State of New Mexico State Engineer Office.

Dolson, J., 2016, Understanding oil and gas shows and seals in the search for hydrocarbons: Switzerland, Springer International Publishing, accessed August 10, 2016, at https://doi.org/10.1007/978-3-319-29710-1.

Dunbar, N.W., 1999, Cosmogenic ${ }^{36} \mathrm{Cl}$-determined age of the Carrizozo lava flows, south-central New Mexico: New Mexico Geology, v. 21, no. 2, p. 25-29.

Dunne, T., Zhang, W., and Aubry, B.F., 1991, Effects of rainfall, vegetation, and microtopography on infiltration and runoff: Water Resources Research, v. 27, no. 9, p. 22712285.

Ellsworth, W.L., 2013, Injection-induced earthquakes: Science, v. 341, accessed July 20, 2017, at https://doi. org/10.1126/science. 1225942.

Engler, T.W., and Cather, M., 2014, Update to the reasonable foreseeable development (RFD) for the BLM Pecos District, SENM: New Mexico Institute of Mining and Technology, accessed October 11, 2017, at https://eplanning.blm.gov/ epl-front-office/projects/lup/64444/80056/93025/Final_ Report-SENM-DEC2014_updated_RFD.pdf.

Entwistle, L.P., 1944, Manganiferous iron-ore deposits near Silver City, New Mexico: New Mexico Bureau of Mines Bulletin 19, $70 \mathrm{p}$.

Ericksen, G.E., Wedow, Helmuth, Jr., Eaton, G.P., and Leland, G.R., 1970, Mineral resources of the Black Range Primitive Area, Grant, Sierra, and Catron Counties, New Mexico: U.S. Geological Survey Bulletin 1319E, accessed October 3, 2017, at https://pubs.usgs.gov/ bul/1319e/report.pdf.

Esri, 2015, ArcGIS 10.3.1 for Desktop: Redlands, Calif., Environmental Systems Research Institute.

Finch, S.T., Jr., 2002, Hydrogeologic framework of the Salt Basin and development of three-dimensional ground-water flow model: Albuquerque, New Mexico, John Shomaker \& Associates, Inc.

Finch, S.T., Jr., 2004, Evaluation of potential water-resource impacts from BLM proposed resource management plan amendment for federal fluid minerals leasing and development in the Salt Basin, New Mexico: Albuquerque, New Mexico, John Shomaker \& Associates, Inc.

Foster, R.W., 1978, Oil and gas evaluation of White Sands Missile Range and Fort Bliss Military Reservation, southcentral New Mexico: New Mexico Bureau of Mines and Mineral Resources Open-File Report 92, 60 p.
Gallegos, T.J., Varela, B.A., Haines, S.S., and Engle, M.A., 2015, Hydraulic fracturing water use variability in the United States and potential environmental implications: Water Resources Research, v. 51, p. 58395845, accessed October 3, 2017, at https://dx.doi. org/10.1002/2015WR017278.

Gile, L.H., 2002, Lake Jornada, an early-middle Pleistocene lake in the Jornada del Muerto Basin, southern New Mexico: New Mexico Geology, v. 24, no. 1, p. 3-14.

Gleason, R.A., and Tangen, B.A., eds., 2014, Brine contamination to aquatic resources from oil and gas development in the Williston Basin, United States: U.S. Geological Survey Scientific Investigations Report 2014-5017, 127 p., accessed June 2, 2017, at http://dx.doi. org/10.3133/sir20145017.

Glover, T.G., 1975, Geology of the Central Organ Mountains Dona Ana County, New Mexico: New Mexico Geologic Society Guidebook, 26th Field Conference, p. 157-161.

Glover, J.F., 2015, Reasonable Foreseeable Development Scenario for oil and gas activities in the Tri-County planning area, south-central New Mexico: U.S. Department of the Interior Bureau of Land Management Final Report.

Greenwood, E., Kottlowski, F.E., Jr., and Thompson, S., III, 1977, Petroleum potential and stratigraphy of the Pedregosa Basin - Comparison with Permian and Orogrande Basins: American Association of Petroleum Geologists Bulletin, v. 61, no. 9 , p. $1448-1469$.

Gregory, K.B., Vidic, R.D., and Dzombak, D.A., 2011, Water management challenges associated with the production of shale gas by hydraulic fracturing: Elements, v. 7, p. 181186, accessed June 2, 2017, at https://dx.doi.org/10.2113/ gselements.7.3.181.

Guerra, K., Dahm, K., and Dundorf, S., 2011, Oil and gas produced water management and beneficial use in the western United States: Bureau of Reclamation Science and Technology Program Report No. 157, 113 p.

Gurdak, J.J., McMahon, P.B., Dennehy, K.F., and Qi, S.L., 2009, Water quality in the High Plains aquifer, Colorado, Kansas, Nebraska, New Mexico, Oklahoma, South Dakota, Texas, and Wyoming, 1999-2004: U.S. Geological Survey Circular 1337, 63 p.

Haller, K.M., 2014, USGS Quaternary fault and fold database of the United States: U.S. Geological Survey, accessed July 26, 2017, at http://earthquake.usgs.gov/hazards/qfaults/ qfaults.zip.

Hallgarth, W.E., 1967, Paleotectonic investigations of the Permian system in the United States, Chapter I: Western Colorado, southern Utah, and northwestern New Mexico: U.S. Geological Survey Professional Paper 515-1, p. 171197. 
Hanson, R.T., McLean, J.S., and Miller, R.S., 1994, Hydrogeologic framework and preliminary simulation of ground-water flow in the Mimbres Basin, southwestern New Mexico: U.S. Geological Survey Water-Resources Investigations Report 94-4011, 118 p.

Harbour, R.L., 1972, Geology of the northern Franklin Mountains, Texas and New Mexico: U.S. Geological Survey Bulletin 1298, 129 p., accessed August 25, 2016, at https://pubs.er.usgs.gov/publication/b1298.

Harkness, J.S., Dwyer, G.S., Warner, N.R., Parker, K.M., Mitch, W.A., and Vengosh, A., 2015, Iodide, bromide, and ammonium in hydraulic fracturing and oil and gas wastewaters-Environmental implications: Environmental Science \& Technology, v. 49, no. 3, p. 1955-1963, accessed June 2, 2017, at https://dx.doi.org/10.1021/es504654n.

Harrison, R.W., and Cather, S.M., 2004, The Hot Springs fault system of south-central New Mexico-Evidence for the northward translation of the Colorado Plateau during the Laramide orogeny, in Cather, S.M., McIntosh, W.C., and Kelly, S.A., eds., Tectonics, geochronology, and volcanism in the southern Rocky Mountains and Rio Grande rift: New Mexico Bureau of Geology and Mineral Resources Bulletin 160, p. 161-179.

Hawley, J.W., 1993, Geomorphic setting and late Quaternary history of pluvial-lake basins in the southern New Mexico region: New Mexico Bureau of Mines and Mineral Resources Open-File Report 391, 28 p.

Hawley, J.W., Hibbs, B.J., Kennedy, J.F., Creel, B.J., Remmenga, M.D., Johnson, M., Lee, M.M., and Dinterman, P., 2000, Trans-international boundary aquifers in southwestern New Mexico: New Mexico Water Resources Research Institute Technical Completion Report, 126 p., accessed July 30, 2016, at https://nmwrri.nmsu.edu/ trans-international-boundary-aquifers-in-southwest-newmexico- $2 /$.

Hawley, J.W., and Kennedy, J.F., 2004, Creation of a digital hydrogeologic framework model of the Mesilla Basin and southern Jornada del Muerto Basin: New Mexico Water Resources Research Institute, Technical Completion Report 332, 105 p., accessed July 30, 2016, at https://nmwrri.nmsu. $\mathrm{edu} / \mathrm{tr} 332 /$

Hayes, P.T., 1964, Geology of the Guadalupe Mountains, New Mexico: U.S. Geological Survey Professional Paper 446, $69 \mathrm{p}$.

Hayes, P.T., 1975, Cambrian and Ordovician rocks of southern Arizona and New Mexico and westernmost Texas: U.S. Geological Survey Professional Paper 873, 106 p., accessed July 30, 2016, at https://pubs.usgs.gov/pp/0873/ report.pdf.
Herrick, E.H., and Davis, L.V., 1965, Availability of ground water in Tularosa Basin and adjoining areas, NewMexico and Texas: U.S. Geological Survey Hydrologic Investigations Atlas HA-191, 1 sheet, scale $1: 500,000$.

Hibbs, B.J., Ashworth, J.B., Boghici, R.N., Hayes, M.E., Creel, B.J., Hanson, A.T., Samani, B.A., and Kennedy, J.F., 1997, Trans-boundary aquifers of the El Paso/Ciudad Juarez/Las Cruces Region: Austin, Texas, Texas Water Development Board.

Hoffer, J.M., 2001, Geology of the West Potrillo Mountains, in Crumpler, L.S., and Lucas, S.G., eds., Volcanology in New Mexico: New Mexico Museum of Natural History and Science Bulletin 18, p. 141-145.

Hoffer, J.M., and Corbitt, L.L., 1991, Evolution of the late Cenozoic Jornada volcano, south-central New Mexico, in Barker, J.M., Kues, B.S., Austin, G.S., and Lucas, S.G., eds., Geology of the Sierra Blanca, Sacramento, and Capitan Ranges, New Mexico: New Mexico Geological Society 42nd Annual Fall Field Conference Guidebook, p. 159-163.

Hood, J.W., and Kister, L.R., 1962, Saline-water resources of New Mexico: U.S. Geological Survey Water-Supply Paper 1601,70 p., 8 pls.

Hudspeth County Underground Water Conservation District No. 1 [HCUWCD\#1], 2013, Groundwater Management Plan, accessed March 15, 2017, at http://www.twdb.texas. gov/groundwater/docs/GCD/hcuwcd1/hcuwcd1_mgmt_ plan2013.pdf.

Huff, G.F., and Chace, D.A., 2006, Knowledge and understanding of the hydrogeology of the Salt Basin in south-central New Mexico and future study needs: U.S. Geological Survey Open-File Report 2006-1358, $17 \mathrm{p}$.

Hutchison, W.R., 2008, Deep-well injection of desalination concentration in El Paso, Texas: Southwest Hydrology, March/April 2008, accessed March 15, 2017, at http://www.swhydro.arizona.edu/archive/V7_N2/feature7. pdf.

Intermountain Oil and Gas BMP Project, 2015, Welcome to the Intermountain Oil and Gas BMP Project website, accessed March 15, 2017, at http://www.oilandgasbmps.org.

Jochems, A.P., and Koning, D.J., 2015, Geologic map of the Williamsburg 7.5-minute quadrangle, Sierra County, New Mexico: New Mexico Bureau of Geology and Mineral Resources Open-File Digital Geologic Map OF-GM 250, scale 1:24,000. 
Jones, M.A., Shomaker, J.W., and Finch, S.T., 2013, Model of groundwater flow in the Animas Uplift and Palomas Basin, Copper Flat Project, Sierra County, New Mexico: Albuquerque, N.M., John Shomaker and Associates, prepared for New Mexico Copper Corporation, a wholly owned subsidiary of THEMAC Resource Group Ltd., accessed October 6, 2016, at http://www.emnrd. state.nm.us/MMD/MARP/documents/2013.08.22 ModelofGroundWaterFlow_CopperFlat_SI025RN.pdf.

Kambhammettu, B.V.N.P., Allena, P., and King, J.P., 2010, Simulation of groundwater flow in the southern Jornada del Muerto Basin, Doña Ana County, New Mexico: New Mexico Water Resources Research Institute Technical Completion Report No. 352, 63 p.

Kelley, V.C., 1971, Geology of the Pecos country, southeastern New Mexico: New Mexico Bureau of Mines and Mineral Resources Memoir 24, 75 p.

Kelley, V.C., and Silver, C., 1952, Geology of the Caballo Mountains: University of New Mexico, Publications in Geology 4, 286 p.

Kilburn, J.E., Stoeser, D.B., Zimbelman, D.R., Hanna W.F., and Gese D.D., 1988, Mineral resources of the West Potrillo Mountains-Mount Riley and the Aden Lava Flow Wilderness Study Areas, Dona Ana and Luna Counties, New Mexico: U.S. Geological Survey Bulletin 1735-B.

King, P.B., 1948, Geology of the southern Guadalupe Mountains, Texas: U.S. Geological Survey Professional Paper 215, $183 \mathrm{p}$.

King, W.E., and Harder, V.M., 1985, Oil and gas potential of the Tularosa Basin-Otero platform-Salt Basin graben area, New Mexico and Texas: New Mexico Bureau of Mines and Mineral Resources Circular 198, 36 p.

King, W.E., Hawley, J.W., Taylor, A.M., and Wilson, R.P., 1971, Geology and groundwater resources of central and western Doña Ana County, New Mexico: New Mexico Bureau of Mines and Mineral Resources, Hydrologic Report 1, 64 p.

Kluth, C.F., 1986, Plate tectonics of the Ancestral Rocky Mountains: Part III. Middle Rocky Mountains, in Peterson, J.A., ed., Paleotectonics and sedimentation in the Rocky Mountain region, United States: American Association of Petroleum Geologists Memoir 41, p. 353-369.

Kluth, C.F., and Coney, P.J., 1981, Plate tectonics of the Ancestral Rocky Mountains: Geology, v. 9, p. 10-15.

Koning, D.J., Machette, M.N., and Kelson, K.I., comps., 2016a, Fault number 2054a, Alamogordo fault, Three Rivers section, in Quaternary Fault and Fold Database of the United States: U.S. Geological Survey, accessed July 26, 2016, at https://earthquakes.usgs.gov/hazards/qfaults.
Koning, D.J., Haller, K.M., Machette, M.N., and Kelson, K.I., comps., 2016b, Fault number 2054b, Alamogordo fault, Sabinata section, in Quaternary Fault and Fold Database of the United States: U.S. Geological Survey, accessed July 26, 2016, at https://earthquakes.usgs.gov/hazards/qfaults.

Koning, D.J., Machette, M.N., and Kelson, K.I., comps., 2016c, Fault number 2054d, Alamogordo fault, McGregor section, in Quaternary Fault and Fold Database of the United States: U.S. Geological Survey, accessed July 26, 2016, at https://earthquakes.usgs.gov/hazards/qfaults.

Kottlowski, F.E., 1955, Geology of the San Andres Mountains, in Fitzsimmons, J.P., ed., South-Central New Mexico: New Mexico Geological Society 6th Annual Fall Field Conference Guidebook, 193 p.

Kottlowski, F.E., 1963, Paleozoic and Mesozoic strata of southwestern and south-central New Mexico: New Mexico Bureau of Mines and Mineral Resources Bulletin 79, 100 p.

Kottlowski, F.E., 1965, Sedimentary basins of south-central and southwestern New Mexico: Bulletin of the American Association of Petroleum Geologists, v. 49, no. 11, p. 2120 2139.

Kottlowski, F.E., 1969, Summary of Late Paleozoic in El Paso border region, in Kottlowski, F.E., and LeMone, D.V., eds., Border stratigraphy symposium: State Bureau of Mines and Mineral Resources Circular 104, p. 38-51.

Kottlowski, F.E., Foster, R.W., and Wengerd, S.A., 1969, Key oil tests and stratigraphic sections in southwest New Mexico, in Cordoba, D.A., Wengerd, S.A., and Shomaker, J.W., eds., The border region (Chihuahua, Mexico, \& USA): New Mexico Geological Society 20th Annual Fall Field Conference Guidebook, p. 186-196.

Kuellmer, F.J., 1954, Geologic section of the Black Range at Kingston, New Mexico: New Mexico Bureau of Mines and Mineral Resources Bulletin 33.

Kues, B.S., 2006, Geological studies of the Guadalupe Mountains area, New Mexico and west Texas, to 1928, in Land, L., Lueth, V.W., Raatz, W., Boston, P., and Love, D.W., eds., Caves and karst of southeastern New Mexico: New Mexico Geological Society Guidebook 57, p. $127-$ 144.

Land, L., Felix, B., and Newton, T., 2014, Regional water table map of the northeastern Tularosa Basin region, Otero and Lincoln Counties, New Mexico: New Mexico Bureau of Geology and Mineral Resources Open-File Report 561.

Land, L., Timmons, S., Rawling, G., and Felix, B., 2012, Water table map of the southern Sacramento Mountains, New Mexico: New Mexico Bureau of Geology and Mineral Resources Open-File Report 542. 
Livingston Associates, P.C., and John Shomaker and Associates, Inc., 2002, Tularosa Basin and Salt Basin Regional Water Plan, 2000-2040, accessed March 15, 2017, at http://livingston-associates.com/40yearplan.pdf.

Livingston Associates, P.C., and John Shomaker and Associates, Inc., 2006, City of Alamogordo 40-Year Water Development Plan 2005-2045, accessed March 15, 2017, at http://ci.alamogordo.nm.us/Assets/ COA+Documents+\$!26+Images/Miscellaneous/ FINAL+Alamogordo+40-Year+Plan+2005-2045+11-22-06. pdf.

Longworth, J.W., Valdez, J.M., Magnuson, M.L., and Richard, K., 2013, New Mexico water use by categories, 2010: New Mexico Office of the State Engineer Technical Report 54, accessed April 5, 2017, at http://www.ose.state.nm.us/Pub/ TechnicalReports/TechReport\%2054NM\%20Water\%20 Use \%20by\%20Categories\%20.pdf.

Lovejoy, E.M.P., 1975, An interpretation of the structural geology of the Franklin Mountains, Texas, in Seager, W.R., Clemons, R.E., and Callender, J.F., eds., Las Cruces country: New Mexico Geological Society 26th Annual Fall Field Conference Guidebook, p. 261-268.

Lozinsky, R.P., 1987, Cross section across the Jornada del Muerto, Engle, and northern Palomas Basins, south-central New Mexico: New Mexico Geology, v. 9, no. 3, p. 55-57, 63.

Lozinsky, R.P., Hunt, A.P., and Wolberg, D.L., 1984, Late Cretaceous (Lancian) dinosaurs from the McRae Formation, Sierra County, New Mexico: New Mexico Geology, v. 6, p. 72-77.

Lucas, S.G., Krainer, K., Voigt, S., Berman, D.S., and Henrici, A., 2014, The lower Permian Abo Formation in the northern Sacramento Mountains, southern New Mexico: New Mexico Geological Society 65th Field Conference Guidebook, p. 287-302.

Luna, M.L., 2005, Potential for ground-water contamination from deep well injection of produced waters in the Salt Basin, New Mexico: University of New Mexico, Master's Thesis.

Machette, M.N., 1987, Preliminary assessment of Quaternary faulting near Truth or Consequences, New Mexico: U.S. Geological Survey Open-File Report 87-652, 38 p.

Machette, M.N., comp., 1996, Fault number 2055, Unnamed fault/monocline, in Quaternary Fault and Fold Database of the United States: U.S. Geological Survey, accessed July 26, 2017, at https://earthquakes.usgs.gov/hazards/qfaults.

Machette, M.N., and Jochems, A.P., comps., 2015a, Fault number 2053a, San Andres Mountains fault, northern section, in Quaternary Fault and Fold Database of the United States: U.S. Geological Survey, accessed July 26, 2017, at https://earthquakes.usgs.gov/hazards/qfaults.
Machette, M.N., and Jochems, A.P., comps., 2015b, Fault number 2056b, Jornada Draw fault, central section, in Quaternary Fault and Fold Database of the United States: U.S. Geological Survey, accessed July 26, 2017, at https://earthquakes.usgs.gov/hazards/qfaults.

Machette, M.N., and Jochems, A.P., comps., 2015c, Fault number 2053b, San Andres Mountains fault, central section, in Quaternary Fault and Fold Database of the United States: U.S. Geological Survey, accessed July 26, 2017, at https://earthquakes.usgs.gov/hazards/qfaults.

Machette, M.N., and Jochems, A.P., comps., 2015d, Fault number 2064, West Robledo fault, in Quaternary Fault and Fold Database of the United States: U.S. Geological Survey, accessed July 26, 2017, at https://earthquakes.usgs.gov/ hazards/qfaults.

Machette, M.N., and Jochems, A.P., comps., 2015e, Fault number 2063, East Robledo fault, in Quaternary Fault and Fold Database of the United States: U.S. Geological Survey, accessed July 26, 2017, at https://earthquakes.usgs.gov/ hazards/qfaults.

Machette, M.N., and Jochems, A.P., comps., 2015f, Fault number 2052a, Organ Mountains fault, Cox Ranch section in Quaternary Fault and Fold Database of the United States: U.S. Geological Survey, accessed July 26, 2017, at https://earthquakes.usgs.gov/hazards/qfaults.

Machette, M.N., and Jochems, A.P., comps., 2015g, Fault number 2065, Fitzgerald fault, in Quaternary Fault and Fold Database of the United States: U.S. Geological Survey, accessed July 26, 2017, at https://earthquakes.usgs.gov/ hazards/qfaults.

Machette, M.N., and Jochems, A.P., comps., 2015h, Fault number 2051b, Artillery Range fault, southern section, in Quaternary Fault and Fold Database of the United States: U.S. Geological Survey, accessed July 26, 2017, at https://earthquakes.usgs.gov/hazards/qfaults.

Machette, M.N., and Jochems, A.P., comps., 2016a, Fault number 2104, Cuchillo Negro fault zone, in Quaternary Fault and Fold Database of the United States: U.S. Geological Survey, accessed July 26, 2017, at https://earthquakes.usgs.gov/hazards/qfaults.

Machette, M.N., and Jochems, A.P., comps., 2016b, Fault number 2101, Mud Springs fault, in Quaternary Fault and Fold Database of the United States: U.S. Geological Survey, accessed July 26, 2017, at https://earthquakes.usgs.gov/ hazards/qfaults.

Machette, M.N., and Jochems, A.P., comps., 2016c, Fault number 2100, Hot Springs fault, in Quaternary Fault and Fold Database of the United States: U.S. Geological Survey, accessed July 26, 2017, at https://earthquakes.usgs.gov/ hazards/qfaults. 
Machette, M.N., and Jochems, A.P., comps., 2016d, Fault number 2133, Fra Cristobal fault zone, in Quaternary Fault and Fold Database of the United States: U.S. Geological Survey, accessed July 26, 2017, at https://earthquakes.usgs. gov/hazards/qfaults.

Machette, M.N., and Jochems, A.P., comps., 2016e, Fault number 2086, Derry Hills fault, in Quaternary Fault and Fold Database of the United States: U.S. Geological Survey, accessed July 26, 2017, at https://earthquakes.usgs.gov/ hazards/qfaults.

Machette, M.N., and Jochems, A.P., comps., 2016f, Fault number 2087a, Red Hills fault, northern section, in Quaternary Fault and Fold Database of the United States: U.S. Geological Survey, accessed July 26, 2017, at https://earthquakes.usgs.gov/hazards/qfaults.

Machette, M.N., and Jochems, A.P., comps., 2016g, Fault number 2088b, Caballo fault, central section, in Quaternary Fault and Fold Database of the United States: U.S. Geological Survey, accessed July 26, 2017, at https:// earthquakes.usgs.gov/hazards/qfaults.

Machette, M.N., and Jochems, A.P., comps., 2016h, Fault number 2078, Ward Tank fault, in Quaternary Fault and Fold Database of the United States: U.S. Geological Survey, accessed July 26, 2017, at https://earthquakes.usgs.gov/ hazards/qfaults.

Mack, G.H., Giles, K.A., and Durr, C.W., 2013, Sequence stratigraphy of the lower-middle Hueco transition interval (lower Permian, Wolfcampian), Robledo Mountains, New Mexico: New Mexico Geology, v. 35, no. 2, p. 27-37.

Mack, G.H., James, W.C., and Salyards, S.L., 1994, Late Pliocene and early Pleistocene sedimentation as influenced by intrabasinal faulting, southern Rio Grande rift, in Keller, G.R., and Cather, S.M., eds., Basins of the Rio Grande rift: Structure, stratigraphy, and tectonic setting: Geological Society of America Special Paper 291, p. 257-264.

Mack, G.H., Kottlowski, F.E., and Seager, W.R., 1998, The stratigraphy of south-central New Mexico, in Mack, G.H., Austin, G.S., and Barker, J.M., eds., Las Cruces country II: New Mexico Geological Society 49th Annual Fall Field Conference Guidebook, p. 135-154.

Mack, G.H., Love, D.W., and Seager, W.R., 1997, Spillover models for axial rivers in regions of continental extension: the Rio Mimbres and Rio Grande in the southern Rio Grande rift, USA: Sedimentology, v. 44, p. 637-652.

Mack, G.H., Seager, W.R., Leeder, M.R., Perez-Arlucea, M., and Salyards, S.L., 2006, Pliocene and Quaternary history of the Rio Grande, the axial river of the southern Rio Grande rift, New Mexico, USA: Earth-Science Reviews, v. 79 , p. 141-162.
Mamer, E.A., Newton, B.T., Koning, D.J., Timmons, S.S., and Kelley, S.A., 2014, Northeastern Tularosa Basin Regional Hydrogeology Study, New Mexico: New Mexico Bureau of Geology and Mineral Resources Open-File Report 562.

Mansurov, Z.A., Ongarbaev, E.K., and Tuleutaev, B.K., 2001, Contamination of soil by crude oil and drilling muds. Use of wastes by production of road construction materials: Chemistry and Technology of Fuels and Oils, v. 37, no. 6, p. 441-443, accessed August 25, 2017, at https://dx.doi. org/10.1023/A:1014279113732.

Mayer, J.R., 1995, The role of fractures in regional groundwater flow: Field evidence and model results from the Basin-and-Range of Texas and New Mexico: The University of Texas at Austin, Ph.D. Dissertation.

Mayer, J.R., and Sharp, J.M., Jr., 1998, Fracture control of regional ground-water flow in a carbonate aquifer in a semiarid region: Geological Society of America Bulletin, v. 110, no. 2, p. 269-283.

McKee, E.D., 1967, Arizona and Western New Mexico, Paleotectonic investigations of the Permian System in the United States: U.S. Geological Survey Professional Paper 515-J, p. 201-223.

McLean, J.S., 1970, Saline ground-water resources of the Tularosa Basin, New Mexico: U.S. Geological Survey Research and Development Progress Report 561, 128 p.

McKnight, C.L., 1986, Descriptive geomorphology of the Guadalupe Mountains, south-central New Mexico and west Texas: Baylor Geological Studies Bulletin 43, 40 p.

Meinzer, O.E., and Hare, R.F., 1915, Geology and water resources of Tularosa Basin, New Mexico: U.S. Geological Survey Water-Supply Paper 343, 317 p., accessed December 19, 2017, at https://pubs.usgs.gov/wsp/0343/ report.pdf.

Morino, K.A., 1996, Reconstruction and interpretation of historical patterns of fire occurrence in the Organ Mountains, New Mexico: University of Arizona, Thesis, $144 \mathrm{p}$.

Nadim, F., Hoag, G.E., Liu, S., Carley, R.J., and Zack, P., 2000, Detection and remediation of soil and aquifer systems contaminated with petroleum products-An overview: Journal of Petroleum Science and Engineering, v. 26, p. $169-178$.

Neal, J.T., Smith, R.E., and Jones, B.F., 1983, Pleistocene Lake Trinity, an evaporite basin in the northern Jornada del Muerto, New Mexico, in Chapin, C.E., and Callender, J.F., eds., Socorro region II: New Mexico Geological Society 34th Annual Fall Field Conference Guidebook, p. 285-290. 
Nelson, E.P., 1986, Geology of the Fra Cristobal Range, southcentral New Mexico, in Clemons, R.E., King, W.E., Mack, G.H., and Zidek, J., eds., Truth of Consequences region: New Mexico Geological Society 37th Annual Fall Field Conference Guidebook, p. 83-91.

Nelson, W.J., Lucas, S.G., Krainer, K., McLemore, V.T., and Elrick, S., 2012, Geology of the Fra Cristobal Mountains, New Mexico, in Lucas, S.G., McLemore, V.T., Lueth, V.W., Spielmann, J.A., and Krainer, K., eds., Geology of the Warm Springs region: New Mexico Geological Society 63rd Annual Fall Field Conference Guidebook, p. 195-210.

New Mexico Bureau of Geology and Mineral Resources [NMBGMR], 2003, Geologic map of New Mexico, scale 1:500,000, accessed in 2016 at https:/geoinfo.nmt.edu/ publications/maps/geologic/state/home.cfml.

New Mexico Interstate Stream Commission and the New Mexico Office of the State Engineer, 2002, New Mexico Water Resource Atlas, accessed August 25, 2017, at http://www.ose.state.nm.us/Pub/planning/PDF/ nmwateratlas.pdf.

New Mexico Office of the State Engineer and the New Mexico Interstate Stream Commission, 2016, Regional water planning, accessed August 25, 2017, at http://www.ose.state. nm.us/Planning/regional_planning.php.

New Mexico Office of the State Engineer and the New Mexico Interstate Stream Commission, 2017a, Water rights, accessed August 25, 2017, at http:/www.ose.state.nm.us/ WR/WRindex.php.

New Mexico Office of the State Engineer and the New Mexico Interstate Stream Commission, 2017b, Water use \& data technical reports, accessed August 25, 2017, at http://www. ose.state.nm.us/Pub/pub_waterUseData.php.

New Mexico Office of the State Engineer and the New Mexico Interstate Stream Commission, 2017c, Underground water basins in New Mexico, accessed October 2, 2017, at http:// www.ose.state.nm.us/Maps/PDF/underground_water.pdf.

New Mexico Office of the State Engineer and the New Mexico Interstate Stream Commission, 2017d, Declared groundwater basins, accessed November 20, 2017, at http:// www.ose.state.nm.us/WR/groundWater.php.

New Mexico Oil Conservation Division [NMOCD], 2004, Notice: No OCD permit required for re-use of produced water at oil and gas operations, accessed August 25, 2016, at http://www.emnrd.state.nm.us/OCD/documents/ Noticeproducedwaterre-use.pdf.

New Mexico Oil Conservation Division [NMOCD], 2016a, OCD imaging, Well file search, accessed 2016 at http:// ocdimage.emnrd.state.nm.us/imaging/WellFileCriteria.aspx.
New Mexico Oil Conservation Division [NMOCD], 2016b, OCD Geographic Information Systems (GIS), GIS Data, NM_Wells_State_Wide_UTM_NAD83_Z13 shapefile, accessed June 9, 2016, at http://www.emnrd.state.nm.us/ OCD/ocdgis.html.

New Mexico Oil Conservation Division [NMOCD], 2016c, Title 19-Natural Resources and Wildlife, Chapter 15: Oil and Gas, accessed July 7, 2016, at http://www.emnrd.state.nm.us/OCD/documents/ SearchablePDFofOCDTitle19Chapter15-Revised10-5-16. pdf.

New Mexico Oil Conservation Division [NMOCD], 2016d, Permitting - Wells OCD Permitting - Wells, New Mexico Energy, Minerals and Natural Resources Department, accessed September 13, 2016, at https://wwwapps.emnrd. state.nm.us/ocd/ocdpermitting/Data/Wells.aspx.

New Mexico Oil Conservation Division [NMOCD], 2017, Oil and gas education, accessed March 12, 2017, at http:/www. emnrd.state.nm.us/OCD/education.html\#frac2.

Newton, B.T., and Allen, Bruce, 2014, Hydrologic investigation at White Sands National Monument: New Mexico Bureau of Geology and Mineral Resources Open-File Report 559, 98 p., accessed March 22, 2017, at https:/geoinfo.nmt.edu/publications/openfile/ downloads/500-599/559/OFR559_White_Sands_with_ Appendices_LR.pdf.

Newton, B.T., and Land, L., 2016, Brackish water assessment in the eastern Tularosa Basin, New Mexico: New Mexico Bureau of Geology and Mineral Resources Open-File Report 582.

Newton, B.T., Rawling, G.C., Timmons, S.S., Land, L., Johnson, P.S., Kludt, T.J., and Timmons, J.M., 2012, Sacramento Mountains hydrogeology study, final technical report, prepared for Otero Soil and Water Conservation District: New Mexico Bureau of Geology and Mineral Resources Open-File Report 543, 77 p.

Newton, Talon, Kludt, Trevor, Love, Dave, and Mamer, Ethan, 2015, Hydrogeology of central Jornada del Muerto: Implications for travel along El Camino Real de Tierra Adentro, Sierra and Doña Ana Counties, New Mexico: New Mexico Bureau of Geology and Mineral Resources OpenFile Report 573.

Nutt, C.J., and O’Neill, J.M., 1998, Geologic framework of Tertiary intrusions of the Cornudas Mountains, southern New Mexico, in Mack, G.H., Austin, G.S., and Barker, J.M., eds., Las Cruces country II: New Mexico Geological Society 49th Annual Fall Field Conference Guidebook, p. 129-134. 
Nutt, C.J., O’Neill, J.M., Kleinkopf, M.D., Klein, D.P., Miller, W.R., Rodriquez, B.D., and McLemore, V.T., 1997, Geology and Mineral Resources of the Cornudas Mountains, New Mexico: U.S. Geological Survey OpenFile Report 97-282, 46 p.

Omernik, J.M., and Griffith, G.E., 2014, Ecoregions of the conterminous United States: Evolution of a hierarchical spatial framework: Environmental Management, v. 54, p. 1249-1266, accessed August 25, 2017, at https://dx.doi. org/10.1007/s00267-014-0364-1.

O’Neill, J.M., 1998, Geologic map of the Cienega School Quadrangle, Otero County, New Mexico, and Hudspeth County, Texas: U.S. Geological Survey IMAP 2630, accessed July 26, 2017, at https://pubs.er.usgs.gov/ publication/i2630.

Orr, B.R., and Myers, R.G., 1986, Water resources in basinfill deposits in the Tularosa Basin, New Mexico: U.S. Geological Survey Water Resources Investigations Report 85-4219, 94 p.

Person, M., Phillips, F., Kelley, S., Timmons, S., Pepin, J., Blom, L., Haar, K., and Murphy, M., 2013, Assessment of the sustainability of geothermal development within the Truth or Consequences hot-springs district, New Mexico: New Mexico Bureau of Geology and Mineral Resources Open-File Report 551, 65 p.

Pike, W.S., 1947, Intertonguing marine and nonmarine Upper Cretaceous deposits of New Mexico, Arizona, and southwestern Colorado: Geological Society of America Memoirs, v. 24, 103 p.

Poole, F.G., Perry, W.J., Jr., Madrid, R.J., and AmayaMartínez, R., 2005, Tectonic synthesis of the OuachitaMarathon-Sonora orogenic margin of southern Laurentia: Stratigraphic and structural implications for timing of deformational events and plate-tectonic model, in Anderson, T.H., Nourse, J.A., McKee, J.W., and Steiner, M.B., eds., The Mojave-Sonora megashear hypothesis: Development, assessment, and alternatives: Geological Society of America Special Paper 393, p. 543-596.

Pray, L.C., 1961, Geology of the Sacramento Mountains escarpment, Otero County, New Mexico: New Mexico Bureau of Mines and Mineral Resources Bulletin 35, 144 p.

PRISM Climate Group, 2017, 30-Year Normals, accessed April 28, 2017, at http://prism.oregonstate.edu/normals/.

Raatz, W.D., 2002, A stratigraphic history of the Tularosa Basin area, south-central New Mexico, in Lueth, V., Giles, K.A., Lucas, S.G., Kues, B.S., Myers, R.G., and UlmerScholle, D., eds., Geology of White Sands: New Mexico Geological Society 53rd Annual Fall Field Conference Guidebook, p. 141-157.
Rawling, G.C., 2005, Geology and hydrologic setting of selected springs on The San Andres National Wildlife Refuge: New Mexico Bureau of Geology and Mineral Resources Open-File Report 493.

Ritchie, A.B.O., 2011, Hydrogeologic framework and development of a three-dimensional finite difference groundwater flow model of the Salt Basin, New Mexico and Texas: Socorro, New Mex., New Mexico Institute of Mining and Technology, Master's thesis, 953 p.

Sandeen, W.M., 1954, Geology of the Tularosa Basin, New Mexico: New Mexico Geological Society 5th Field Conference Guidebook, p. 81-88.

Scanlon, B.R., Reedy, R.C., and Nicot, J-P., 2014, Comparison of water use for hydraulic fracturing for unconventional oil and gas versus conventional oil: Environmental Science \& Technology, v. 48, p. 12386-12393, accessed April 28, 2017, at https://dx.doi.org/10.1021/es502506v.

Seager, W.R., 1981, Geology of Organ Mountains and southern San Andres Mountains, New Mexico: New Mexico Bureau of Mines \& Mineral Resources, University of New Mexico, p. 13-17, accessed October 27, 2016, at https://geoinfo.nmt.edu/publications/monographs/memoirs/ downloads/36/Memoir\%2036.pdf.

Seager, W.R., and Clemons, R.E., 1975, Middle to late Tertiary geology of Cedar Hills-Selden Hills area, Doña Ana County, New Mexico: New Mexico Bureau of Mines and Mineral Resources Circular 133, 23 p.

Seager, W.R., Kottlowski, F.E., and Hawley, J.W., 1976, Geology of Doña Ana Mountains, New Mexico: New Mexico Bureau of Mines \& Mineral Resources, p. 5-26, accessed October 27, 2016, at http://geoinfo.nmt.edu/ publications/monographs/circulars/downloads/147/ Circular147.pdf.

Seager, W.R., Kottlowski, F.E., and Hawley, J.W., 2004, Cross sections, tectonic map, diagrammatic section, and references, Robledo Mountains and vicinity, in Seager, W.R., Kottlowski, F.E., and Hawley, J.W., 2008, Geologic map of the Robledo Mountains and vicinity, Doña Ana County, New Mexico: New Mexico Bureau of Mines and Mineral Resources Open-File Report 509, accessed October 27, 2016, at https:/geoinfo.nmt.edu/publications/ openfile/downloads/500-599/509/.

Sharp, J.M., Jr., Mayer, J.R., and McCutcheon, E., 1993, Hyrdrogeologic trends in the Dell City area, Hudspeth County, Texas: New Mexico Geological Society Guidebook, 44th Field Conference, Carlsbad Region, New Mexico and West Texas. 
Sigstedt, S.C., Phillips, F.M., and Ritchie, A.B.O., 2016, Groundwater flow in an 'underfit' carbonate aquifer in a semiarid climate: Application of environmental tracers to the Salt Basin, New Mexico (USA): Hydrogeology Journal, v. 24, no. 4, p. 841-863, accessed October 27, 2016, at https://doi.org/10.1007/s10040-016-1402-2.

Silver, C., 1955, Geology of the Caballo Mountains, in South-Central New Mexico, in Fitzsimmons, J.P., ed., New Mexico Geological Society 6th Annual Fall Field Conference Guidebook, 193 p.

Sloan, C.E., and Garber, M.S., 1971, Ground-water hydrology of the Mescalero Apache Indian Reservation, southcentral New Mexico: U.S. Geological Survey Hydrologic Investigations Atlas HA-349, 1 sheet.

Stageman, J.C., 1988, Petrography and provenance of Cambro-Ordovician Bliss Sandstone, southern New Mexico and west Texas: New Mexico Geological Society 39th Field Conference Guidebook, p. 123-126.

Stevenson, F.V., 1945, Devonian of New Mexico: The Journal of Geology, v. 53, p. 217-245.

Sullivan Graham, E.J., Jakle, A.C., and Martin, F.D., 2015, Reuse of oil and gas produced water in south-eastern New Mexico: Resource assessment, treatment processes, and policy: Water International, v. 40, no. 5-6, p. 809-823, https://doi.org/10.1080/02508060.2015.1096126.

Sweetkind, D.S., 2017, Three-dimensional hydrogeologic framework model of the Rio Grande transboundary region of New Mexico and Texas, USA, and northern Chihuahua, Mexico: U.S. Geological Survey Scientific Investigations Report 2017-5060, 49 p., accessed December 19, 2017, at https://doi.org/10.3133/sir20175060.

Sweetkind, D.S., Hanson, R.T., Ritchie, A.B., and Hawley, J.W., 2017, Data release of three-dimensional hydrogeologic framework model of the Rio Grande Transboundary region of New Mexico and Texas, USA and northern Chihuahua, Mexico: U.S. Geological Survey data release, accessed December 19, 2017, at https://doi.org/10.5066/F7JM27T6.

Taylor, J.F., Myrow, P.M., Ripperdan, R.L., Loch, J.D., and Ethington, R.L., 2004, Paleoceanographic events and faunal crises recorded in the Upper Cambrian and Lower Ordovician of west Texas and southern New Mexico, in Nelson, E.P., and Erslev, E.A., eds., Field trips in the Southern Rocky Mountains, U.S.A.: Geological Society of America Field Guide 5, p. 167-183.

Terracon, John Shomaker \& Associates, Inc., Livingston Associates, LLC, Inc., Zia Engineering and Environmental, Inc., and Sites Southwest, 2004, The New Mexico lower Rio Grande regional water plan, July 27, 2016, at http://www.wrri.nmsu.edu//rgwuo/rwp/ LowerRioGrandeRegionalWaterPlan.pdf.
The Wilderness Society, 2016, Seven ways oil and gas drilling is bad news for the environment, accessed July 18, 2016, at http://wilderness.org/seven-ways-oil-and-gas-drilling-badnews-environment.

Thiros, S.A., Paul, A.P., Bexfield, L.M., and Anning, D.W., 2014, The quality of our Nation's waters-Water quality in basin-fill aquifers of the southwestern United States: Arizona, California, Colorado, Nevada, New Mexico, and Utah, 1993-2009: U.S. Geological Survey Circular 1358, 113 p., accessed August 25, 2016, at http://dx.doi. org/10.3133/cir1358.

Thompson, Sam, III, and Bieberman, R.A., 1975, Oil and gas exploration wells in Dona Ana County, New Mexico, in Seager, W.R., Clemons, R.E., and Callender, J.F., eds., Las Cruces country: New Mexico Geological Society 26th Annual Fall Field Conference Guidebook, p. 171-174.

Tillery, Anne, 2011, Estimates of mean-annual streamflow and flow loss for ephemeral channels in the Salt Basin, southeastern New Mexico, 2009: U.S. Geological Survey Scientific Investigations Report 2011-5062, 20 p.

U.S. Climate Data, 2017, U.S. Climate Data website, accessed July 7, 2016, at http://www.usclimatedata.com.

U.S. Energy Information Administration, 2015, Annual Energy Outlook, accessed January 4, 2016, at http://www.eia.gov/ forecasts/aeo/.

U.S. Environmental Protection Agency [EPA], 2002, Protecting drinking water through underground injection control: Drinking water pocket guide \#2.

U.S. Environmental Protection Agency [EPA], 2016a, Ecoregions, accessed August 28, 2017, at https://www.epa. gov/eco-research/ecoregions.

U.S. Environmental Protection Agency [EPA], 2016b, Controlling air pollution from the oil and natural gas industry, accessed January 4, 2016, at https://www.epa.gov/ controlling-air-pollution-oil-and-natural-gas-industry.

U.S. Environmental Protection Agency [EPA], 2016c, Hydraulic fracturing for oil and gas: Impacts from the hydraulic fracturing water cycle on drinking water resources in the United States (final report): Washington, D.C., U.S. Environmental Protection Agency, EPA/600/R-16/236F.

U.S. Environmental Protection Agency [EPA], 2016d, Drinking water regulations and contaminants, accessed August 28, 2017, at https:/www.epa.gov/dwregdev/ drinking-water-regulations-and-contaminants.

U.S. Environmental Protection Agency [EPA], 2016e, TENORM: Oil and gas production wastes, accessed December 19, 2016, at https://www.epa.gov/radiation/ tenorm-oil-and-gas-production-wastes. 
U.S. Environmental Protection Agency [EPA], 2017, Table of secondary standards, accessed April 3, 2017, at https:// www.epa.gov/dwstandardsregulations/secondary-drinkingwater-standards-guidance-nuisance-chemicals\#table.

U.S. Geological Survey [USGS], 2007, Facing tomorrow's challenges-U.S. Geological Survey science in the decade 2007-2017: U.S. Geological Survey Circular 1309, 70 p.

U.S. Geological Survey [USGS], 2013a, USGS NED n33w105 1 arc-second $20131 \times 1$ degree ArcGrid, accessed July 15, 2016, at https://nationalmap.gov/elevation.html.

U.S. Geological Survey [USGS], 2013b, USGS NED n33w106 1 arc-second 20131 x 1 degree ArcGrid, accessed July 15, 2016, at https://nationalmap.gov/elevation.html.

U.S. Geological Survey [USGS], 2013c, USGS NED n33w108 1 arc-second $20131 \times 1$ degree ArcGrid, accessed July 15,2016 , at https://nationalmap.gov/elevation.html..

U.S. Geological Survey [USGS], 2013d, USGS NED n34w106 1 arc-second 20131 x 1 degree ArcGrid, accessed July 15, 2016, at https://nationalmap.gov/elevation.html.

U.S. Geological Survey [USGS], 2013e, USGS NED n34w107 1 arc-second 20131 x 1 degree ArcGrid, accessed July 15, 2016, at https://nationalmap.gov/elevation.html.

U.S. Geological Survey [USGS], 2013f, USGS NED n34w108 1 arc-second 20131 x 1 degree ArcGrid, accessed July 15, 2016, at https://nationalmap.gov/elevation.html.

U.S. Geological Survey [USGS], 2016a, USGS NED 1 arcsecond n32w107 1 x 1 degree ArcGrid 2016, accessed July 15, 2016, at https://nationalmap.gov/elevation.html.

U.S. Geological Survey [USGS], 2016b, USGS NED 1 arc-second n33w107 1 x 1 degree ArcGrid 2016 accessed July 15, 2016, at https://nationalmap.gov/elevation.html.

U.S. Geological Survey [USGS], 2016c, Energy Resources Program: National Produced Waters Geochemical Database, accessed August 28, 2017, at https://energy.usgs.gov/EnvironmentalAspects/ EnvironmentalAspectsofEnergyProductionandUse/ ProducedWaters.aspx\#3822349-data.

U.S. Geological Survey, 2017a, National Geologic Map Database, Geolex Search, accessed May 18, 2017, at https://ngmdb.usgs.gov/Geolex/search.

U.S. Geological Survey, 2017b, The National Geologic Map Database, accessed May 19, 2017, at https://ngmdb.usgs. gov/ngmdb/ngmdb_home.html.

U.S. Geological Survey, 2017c, USGS water data for the Nation: U.S. Geological Survey National Water Information System database, accessed July, 15, 2017, at https://doi. org/10.5066/F7P55KJN.
U.S. Geological Survey Geologic Names Committee, 2007, Divisions of geologic time-Major chronostratigraphic and geochronologic units: U.S. Geological Survey Fact Sheet 2007-3015, accessed January 6, 2017, at https://pubs.usgs. gov/fs/2007/3015/fs2007-3015.pdf.

U.S. Geological Survey [USGS] and U.S. Department of Agriculture, Natural Resources Conservation Service, 2013, Federal standards and procedures for the National Watershed Boundary Dataset (WBD) (4 ed.): U.S. Geological Survey Techniques and Methods 11-A3, 63 p., accessed August 28, 2016, at http://pubs.usgs.gov/tm/ $\mathrm{tm} 11 \mathrm{a} 3 /$.

Veil, J.A., Puder, M.G., Elcock, D., and Redweik, R.J., Jr., 2004, A white paper describing produced water from production of crude oil, natural gas, and coal bed methane: Argonne National Laboratory, accessed August 28, 2016, at http://109.4iranian.com/uploads/prodwaterpaper_1270.pdf.

Wasiolek, Maryann, 1991, The hydrogeology of the Permian Yeso Formation within the upper Rio Hondo Basin and the eastern Mescalero Apache Indian Reservation, Lincoln and Otero Counties, New Mexico, in Barker, J.M., Kues, B.S., Austin, G.S., and Lucas, S.G., eds., New Mexico Geological Society Guidebook, 42d Field Conference, Sierra Blanca, Sacramento, Capitan Ranges, p. 343-351.

Watson, I.C., Morin, O.J., and Henthorne, L., 2003, Desalting handbook for planners: Bureau of Reclamation, Desalination and Water Purification Research and Development Program Report 72, 316 p., accessed January 10, 2017, at http://www.usbr.gov/research/AWT/ reportpdfs/report072.pdf.

Weir, J.E., Jr., 1965, Geology and availability of ground water in the northern part of the White Sands Missile Range and vicinity, New Mexico: U.S. Geological Survey WaterSupply Paper 1801, 77 p.

Western Regional Climate Center, 2017, Climate of New Mexico, accessed February 25, 2017, at http://www.wrcc. dri.edu/narratives/newmexico/.

Wilkins, D.W., 1986, Geohydrology of the southwest alluvial basins regional aquifer-systems analysis, parts of Colorado, New Mexico, and Texas: U.S. Geological Survey WaterResources Investigations Report 84-4224, 61 p.

Wilson, J.L., 1967, Cyclic and reciprocal sedimentation in Virgilian strata of southern New Mexico: Geological Society of America Bulletin, v. 78, p. 805-818.

Wilson, C.A, White, R.R., Orr, B.R., and Roybal, R.G., 1981, Water resources of the Rincon and Mesilla Valleys and adjacent areas, New Mexico: U.S. Geological Survey Technical Report 43, 514 p., accessed October 3, 2017, at https://pubs.er.usgs.gov/publication/70042517. 
For more information about this publication, contact New Mexico Water Science Center

For additional information visit https://nm.water.usgs.gov/

Publishing support provided by Lafayette Publishing Service Center 



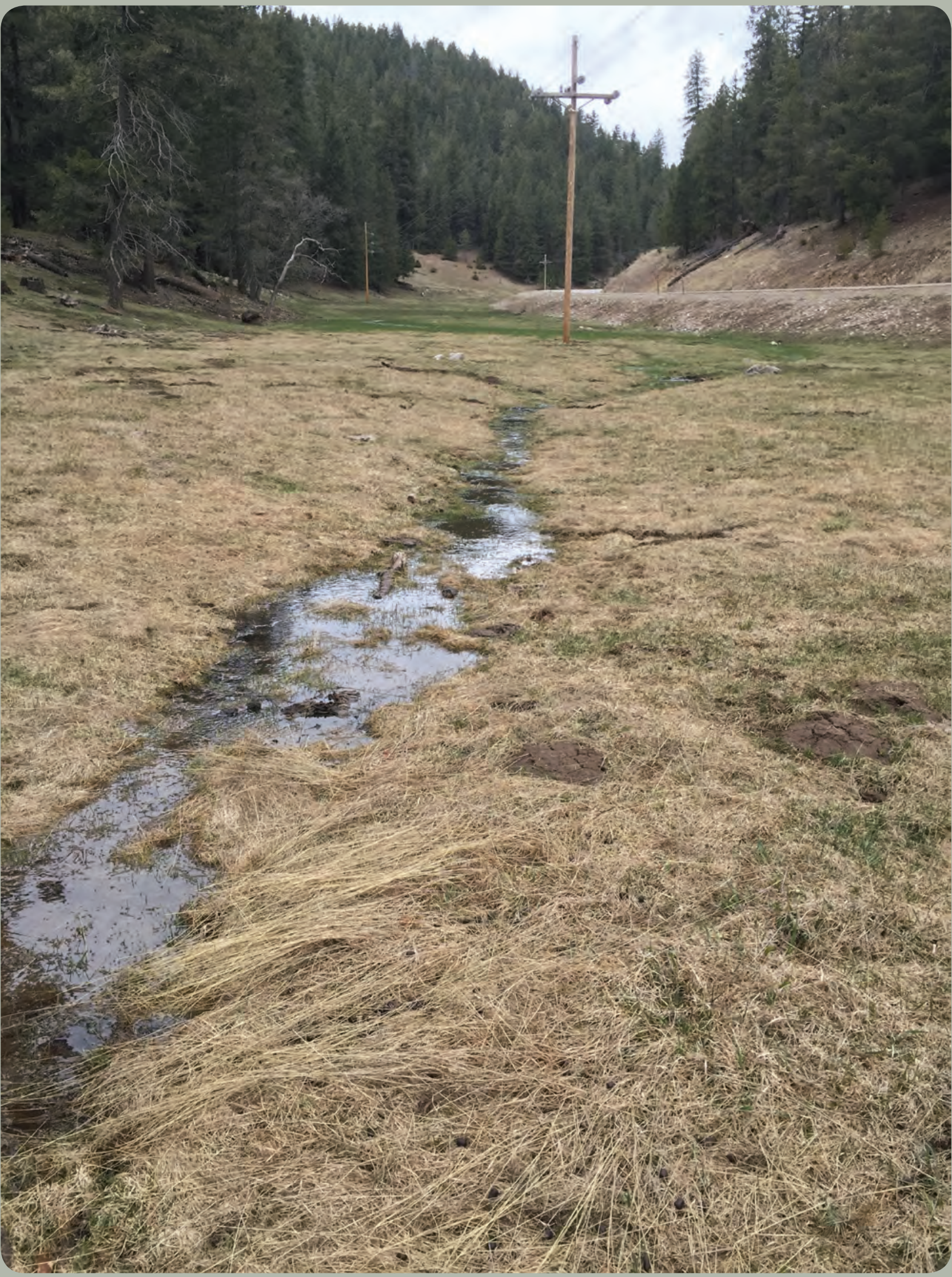

